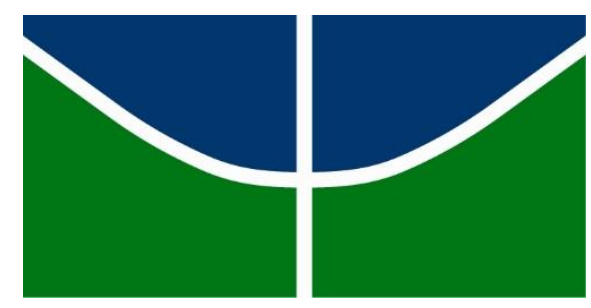

UNIVERSIDADE DE BRASÍLIA INSTITUTO DE ARTES PROGRAMA DE PÓS-GRADUAÇÃO EM ARTES

CORPOS HEMANGESCRITOS: MACROIMPRESSÕES ARTÍSTICAS PROJEÇÕES PARA UM NOVO OLHAR

TATIANA SILVA RODRIGUES

Brasília 

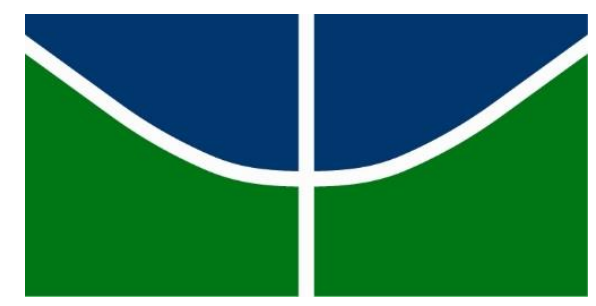

UNIVERSIDADE DE BRASÍLIA

INSTITUTO DE ARTES

PROGRAMA DE PÓS-GRADUAÇÃO EM ARTES

\title{
CORPOS HEMANGESCRITOS: MACROIMPRESSÕES ARTÍSTICAS - PROJEÇÕES PARA UM NOVO OLHAR
}

\author{
TATIANA SILVA RODRIGUES
}

Dissertação de Mestrado apresentada ao Programa de Pós-graduação em Arte, Instituto de Arte da UnB - Universidade de Brasília, como requisito parcial para obtenção do título de Mestre em Artes. Área de concentração: Arte Contemporânea. Linha de pesquisa: Arte e Tecnologia. Orientada pela Professora Doutora Fátima Aparecida dos Santos.

Brasília - DF

Dezembro, 2014 
CORPOS HEMANGESCRITOS: MACROIMPRESSÕES ARTÍSTICAS PROJEÇÕES PARA UM NOVO OLHAR

\author{
TATIANA SILVA RODRIGUES
}

Dissertação de Mestrado apresentada ao Programa de Pós-graduação em Arte, Instituto de Arte da UnB - Universidade de Brasília, como requisito parcial para obtenção do título de Mestre em Artes. Área de concentração: Arte Contemporânea. Linha de pesquisa: Arte e Tecnologia. Orientada pela Professora Doutora Fátima Aparecida dos Santos.

Aprovada em:

BANCA EXAMINADORA:

Professora Doutora Fátima Aparecida dos Santos

PPG ARTE - Universidade de Brasília

(Orientadora)

Professor Doutor Silvio Zamboni

PPG ARTE - Universidade de Brasília

(Examinador)

Professor Doutor Rogério José Câmara

PPG ARTE - Universidade de Brasília

(Examinador)

Professora Doutora Virgínia Tiradentes Souto

PPG ARTE - Universidade de Brasília

(Suplente) 
"Os Teus olhos viram o meu corpo ainda informe, e no Teu livro todas estas coisas foram escritas; as quais iam sendo dia a dia formadas, quando nem ainda uma delas havia".

Salmos 139:16

"Os olhos são a lâmpada do corpo. Portanto, se teus olhos estiverem são, todo o teu corpo terá luz". Mateus 6:22 


\section{AGRADECIMENTOS}

De maneira especial, quero agradecer a Deus, autor da minha vida, por conceder-me o privilégio de confiar a mim este desafio. Obrigada pelo fortalecimento nesta jornada em busca do conhecimento e por me presentear com a sensibilidade de extrair das marcas da vida poesias e criações artísticas. A Ti dedico toda Honra!

A minha amada e inestimável mãe, Irmelina de M. S. Rodrigues, que tem me dedicado, em todas as circunstâncias, todo o seu amor e carinho. Eu jamais conseguirei agradecer as valorosas sementes que tem sido pacientemente regadas em meu coração. Por acreditar que meu potencial pode sempre alçar voos cada vez mais altos, a você atribuo minha garra e determinação. Certamente, você é coparticipante desta conquista!

Ao meu amado pai, José Arimatéa Paula Rodrigues, por toda dedicação e esforço para que eu tivesse oportunidades por meio de uma base sólida nos estudos.

A minha amada irmã, Juliana Silva Rodrigues, que sempre me incentiva e acredita nos meus projetos. Agradeço imensamente pela ajuda com a tradução e por sua entrega de maneira tão intensa às composições artísticas deste trabalho.

Agradeço muitíssimo a Professora Doutora Fátima Aparecida dos Santos por acreditar na potencialidade do tema e por orientar-me nos aprofundamentos teóricos e construções artísticas desta pesquisa. Também, sou grata por toda a paciência, confiança e incentivo recebidos, principalmente, durante as adversidades enfrentadas ao longo desse processo.

Minha gratidão ao Professor Doutor Silvio Zamboni que, desde a graduação, tem contribuído de maneira valiosa nos momentos mais importantes da minha trajetória acadêmica. Suas orientações, apontamentos de leituras, debates, conselhos e incentivos certamente alicerçaram a construção desta obra.

A Professora Mestra Aline Essenburg pela dedicação de leitura, sugestões e incentivo desde as primeiras concepções do tema.

A minha querida amiga Tatiana de Baptista Raineri por todas as palavras de incentivo, intercessões e empenho nas traduções dos textos.

Agradeço ao Paulo Roberto de Freitas da Silva por toda a ajuda, incentivo e importantes contribuições fotográficas.

Meus agradecimentos ao Daniel Schofield por acreditar neste projeto e pela ajuda com suas valorosas produções artísticas. 


\section{RESUMO}

Propõe-se, nesta dissertação, estudar os possíveis diálogos entre o corpo, a marca de nascença hemangioma e a fotografia. Para tanto, a resultante das reflexões teóricas imergem no campo da arte que, permeando-se dos recursos tecnológicos, disponibiliza as ferramentas necessárias para construção do trabalho poético desta pesquisa. Como fundamentação, buscou-se apoio nos seguintes autores: Nathaniel Hawthorne com o conto intitulado The Birthmark -A marca de nascença-, literatura que serviu de paradigma poético para a execução do trabalho; Henri-Pierre Jeudy que traz o entendimento de um corpo heterônimo; Peter Pál Pelbart auxilia na compreensão do esgotamento do corpo; Lucrécia Ferrara elucida as importantes transformações ocorridas na recepção da obra de arte; Júlio Plaza que pontua a relação entre autor-obra-recepção; Silvio Zamboni aproxima as relações entre arte e ciência, ampliando, assim, as discussões entre arte e fotografia proposta por Annateresa Fabris; Richard Dawkins traz um comparativo entre o sistema do olho enquanto organismo biológico e a câmera fotográfica; e, finalmente Philippe Dubois e Roland Barthes trazem abordagens sobre o processo fotográfico. Nas produções artísticas, o hemangioma, corpus desta pesquisa, renomeado como macroimpressões do corpo, é projetado no corpo do Outro, estabelecendo, assim, relações com os recursos tecnológicos da fotografia. Objetiva-se com esta proposta que as inquietações e investigações sobre o tema hemangioma possibilitem que o Outro, a partir das experimentações artísticas, possa projetar um novo olhar rumo às marcas de nascença.

PALAVRAS-CHAVE: Hemangioma; Corpo; Arte, Fotografia e Projeção. 


\begin{abstract}
This dissertation comprises a dialogue between the body, the hemangioma birthmark and the photography. For this purpose, Art permeated with technology provides the source of its reflections; reflections that form a poetic work of research. The theory of the study is supported by the following authors: a short story by Nathaniel Hawthorne -'The Birthmark'- which serves as an poetic paradigm for the work; Henri-Pierre Jeudy provides an understanding of heteronym bodies; Peter Pál Pelbart assists in understanding the depletion of the body; Lucrécia Ferrara elucidates important transformations occurred in art work's reception; Júlio Plaza examines the relation between author, the work and its reception; Silvio Zamboni approach the relationship between art and science, by broadening the discussion on art and photography proposed by Annateresa Fabris; Richard Dawkins compares the system of the body's biological eye and technology's camera eye; and Philippe Dubois and Roland Barthes provide a discourse on the photographic process. In the Art production, the hemangioma, the corpus of this artistic study, renamed as "macro prints" here is projected onto another's body. Therefore stablish a relationship with the technological resource of the photograph. Photographic images of the birthmark are projected onto another's body; different bodies providing a bridge between technology, the body and art. The goal of this dissertation is to bring together these discourses and take a fresh look at birthmarks through art experience.
\end{abstract}

KEY WORDS: Hemangioma; Body; Art; Photography and Projection. 


\section{LISTA DE FIGURAS}

Fig.1- Fada marcando bochecha de Georgiana..................................................17

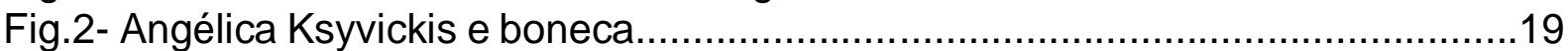

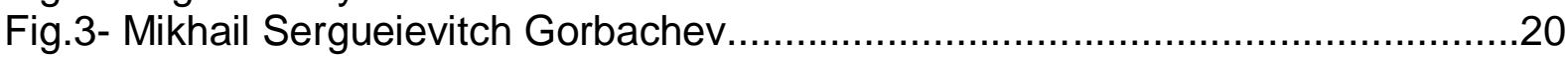

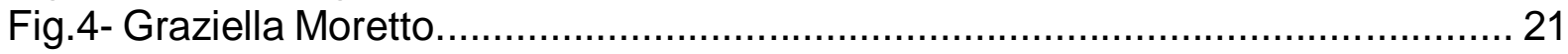

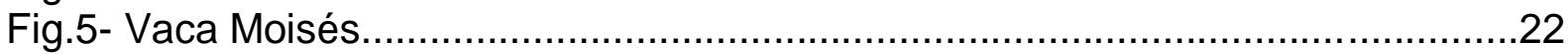

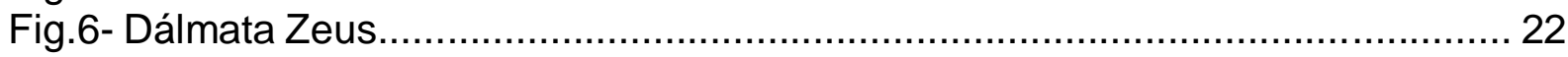

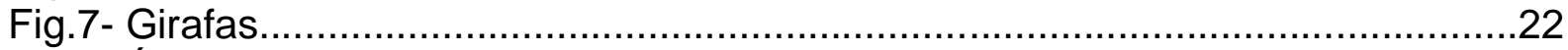

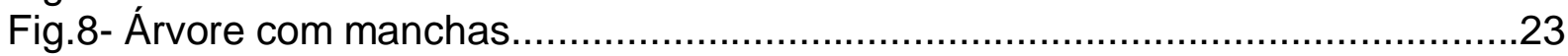

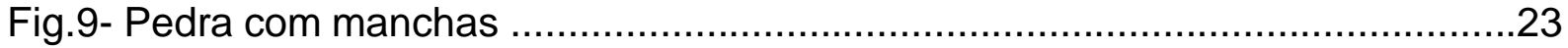

Fig.10- Marcas de Superação....................................................................... 24

Fig.11- A marca de nascença de Georgiana......................................................28

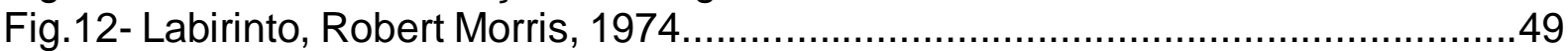

Fig.13- "A Casa é o corpo: Labirinto", Lygia Clark, 1968 ......................................50

Fig.14- Henry Ford Hospital, (A cama voadora), Frida Kahlo, 1932 ..........................54

Fig.15- "Marca de Nascença Azul", Eduardo Sancinetti, 2010.................................56

Fig.16- Réplica de bebê com marca de nascença, Verlânia do Carmo.........................56

Fig.17- Sem Título- Davis Ayer, Portfólio: Time Travel I..........................................59

Figs.18 e19- Sem Título e Sem Título- Davis Ayer, Portfólio: Time Travel I.................60

Fig.20-Várias pupilas, incluindo diafragma de uma câmara, Richard Dawkins, 1998......

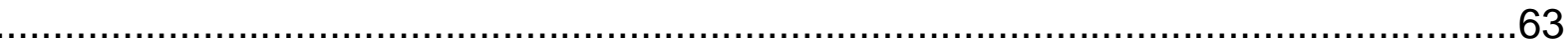

Figs.21 e 22- Marcas de nascença 1 e 2, Paulo Roberto de Freitas, 2012.................68

Fig.23- Marcas de nascença: recortes, Paulo Roberto de Freitas, 2012 ...................69

Figs.24 e 25- Marcas de nascença avermelhadas, Paulo R. de Freitas, 2011 .............70

Figs.26, 27 e 28- "Desenhos do hemangioma", Tatiana Rodrigues, 2014..................71

Fig.29- Texturas do hemangioma, Tatiana Rodrigues, 2009................................72

Fig.30- Nuvens coloridas, Tatiana Rodrigues, 2014 ........................................72

Figs.31, 32 e 33, Marcas de nascença 3, Paulo Roberto de Freitas (2012).....................

Alexandre Sá (2013) e Tatiana Rodrigues (2014)..............................................75

Figs.34, 35 e 36, Marcas de nascença 4, Paulo Roberto de Freitas (2012).....................

Alexandre Sá (2013) e Tatiana Rodrigues (2014)..............................................75

Figs.37, 38 e 39, Marcas de nascença 5, Paulo Roberto de Freitas (2012) .....................

Alexandre Sá (2013) e Tatiana Rodrigues (2014)...............................................76

Figs.40, 41,42 e 43- Série fotográfica: Fragmentos hemangescritos 1.........................

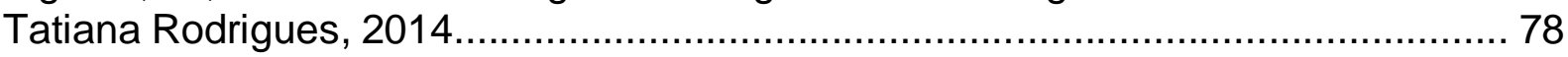

Figs.44, 45,46 e 47- Série fotográfica: Fragmentos hemangescritos 1 .........................

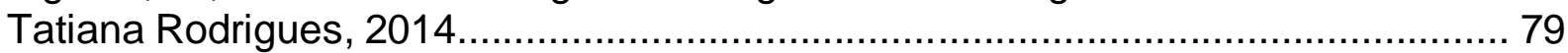

Figs.48, 49 e 50- Mini projetor MPro 110 3M, Tatiana Rodrigues, 2014...................80

Figs.51, 52 e 53- Série fotográfica: Fragmentos hemangescritos 1 ...............................

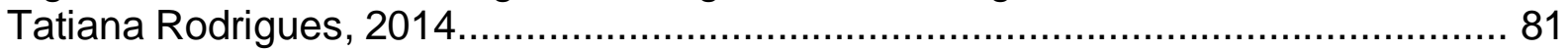

Figs.54 e 55- Série fotogr.: Fragmentos hemangescritos 2, Daniel Schofield, 2014.......

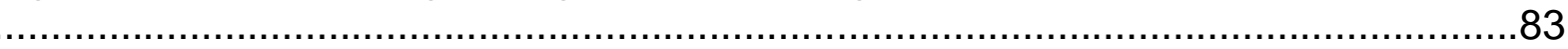

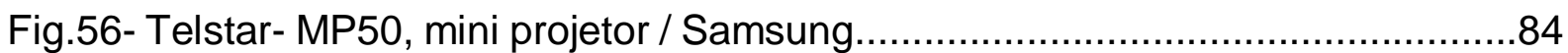

Fig.57- Série fotogr.: Fragmentos hemangescritos 2, Daniel Schofield, 2014 ...........85

Figs.58 e 59- Série fotogr.: Fragmentos hemangescritos 2, Juliana Rodrigues, 2014.....

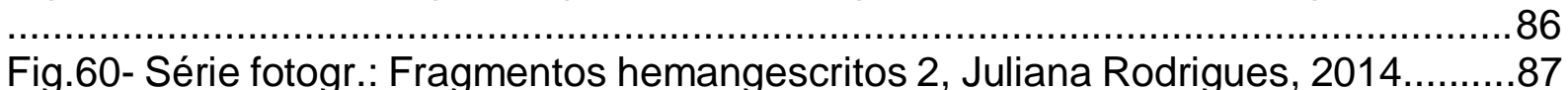

Fig.61- Angioressonância da perna esquerda, DAPI, 2012 …..............................88

Fig.62- Série fotogr.: Angioressonância hemangescrita, Tatiana Rodrigues, 2014.... 89 
Fig.63- Série fotográfica: Angioressonância hemangescrita, Tatiana Rodrigues 2014

Figs.64 e 65- Série fotográfica: Angioressonância hemangescrita, Tatiana Rodrigues... 2014

Figs. 66 e 67- Série fotográfica: Angioressonância hemangescrita, Tatiana Rodrigues... 2014 92

Fig.68- Série fotográfica: Angioressonância hemangescrita, Tatiana Rodrigues... 2014

Figs. 69 e 70- Série fotográfica: Corporação hemangescrita 1, Tatiana Rodrigues.. 2014

Figs.71 e 72- Série fotográfica: Corporação hemangescrita 1, Tatiana Rodrigues. 2014

Figs. 73 e 74- Série fotográfica: Corporação hemangescrita 1, Tatiana Rodrigues 2014

Fig.75- Série fotográfica: Corporação hemangescrita 1, Tatiana Rodrigues.

Figs.76 e 77- Série fotográfica: Corporação hemangescrita 1, Tatiana Rodrigues. 2014

Figs.78 e 79- Série fotográfica: Corporação hemangescrita 1, Tatiana Rodrigues. 2014

Figs.80 e 81- Convergência de projeções, Tatiana Rodrigues, 2014. 100

Fig.82- Série fotográfica: Corpos hemangescritos, Tatiana Rodrigues, 2014..........101

Figs.83 e 84- Série fotogr.: Corpos hemangescritos, Tatiana Rodrigues, 2014........102

Figs.85 e 86- Série fotogr.: Corpos hemangescritos, Tatiana Rodrigues, 2014........103

Fig.87- Série fotogr.: Corpos hemangescritos, Tatiana Rodrigues, 2014 ...............104

Figs.88 e 89- Série fotogr.: Corpos hemangescritos, Tatiana Rodrigues, 2014.........105

Figs.90 e 91- Série fotogr.: Corpos hemangescritos, Tatiana Rodrigues, 2014 .........106

Figs.92 e 93- Série fotogr.: Corpos hemangescritos, Tatiana Rodrigues, 2014 .........107

Figs.94 e 95- Série fotogr.: Corpos hemangescritos, Tatiana Rodrigues, 2014 .........108

Figs.96 e 97- Série fotogr.: Corpos hemangescritos, Tatiana Rodrigues, 2014.........109

Figs.98 e 99- Série fotogr.: Corpos hemangescritos, Tatiana Rodrigues, 2014 ........110

Figs. 100 e 101- Série fotogr.: Corpos hemangescritos, Tatiana Rodrigues, 2014.....111

Fig.102- Série fotogr.: Corpos hemangescritos, Tatiana Rodrigues, 2014 .............112

Figs.103 e 104- Série fotogr.: Corpos hemangescritos, Tatiana Rodrigues, 2014.....113

\section{ANEXO}

Fig.105- Mutilações Fetais, Tatiana Rodrigues, 2004 ......................................126

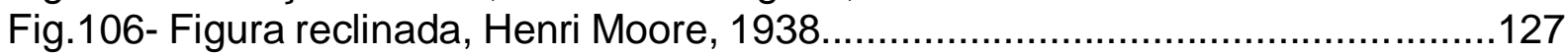

Fig.107- Estudos de corpo para obra Duo Corpos, Tatiana Rodrigues, 2006...........127

Fig.108- Duo Corpos, Tatiana Rodrigues, 2006............................................128

Fig.109- Metamorfoses, Tatiana Rodrigues, 2008.......................................129

Fig.110- Retrato de Fabiana, Waldemar Cordeiro, 1970...................................130

Fig.111- A mulher que não é B.B., Waldemar Cordeiro, 1971............................130

Fig.112- Experimentações com fotografia e iluminação, Tatiana Rodrigues, 2005...131

Fig.113- Série fotográfica1: Hemangiomas, Tatiana Rodrigues, 2009....................133

Figs.114 e 115- Série fotográfica1: Hemangiomas, Tatiana Rodrigues, 2009...........134

Fig.116- Série fotográfica 2: Hemangiomas, Tatiana Rodrigues, 2009...................135

Fig.117- Série fotográfica 3: Hemangiomas, Tatiana Rodrigues, 2009...................136 


\section{SUMÁRIO}

RESUMO

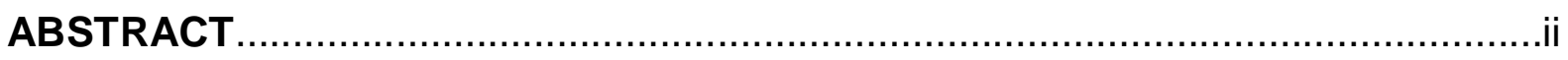

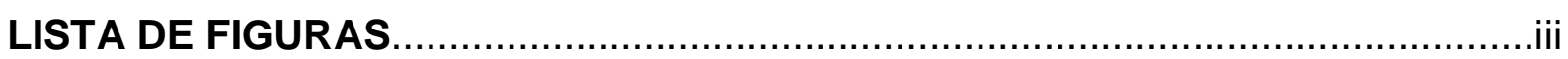

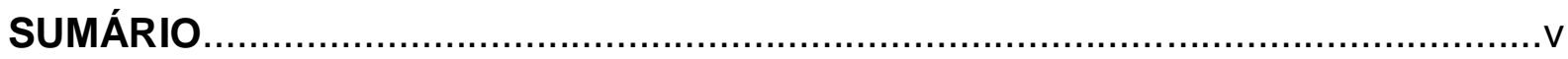

INTRODUÇÃO

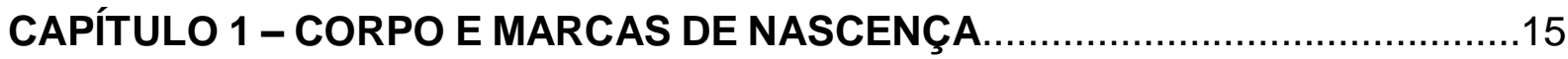

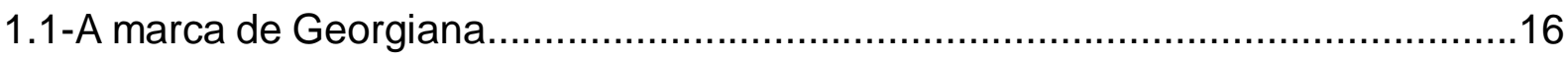

1.2-Crenças populares e marca de nascença.....................................................17

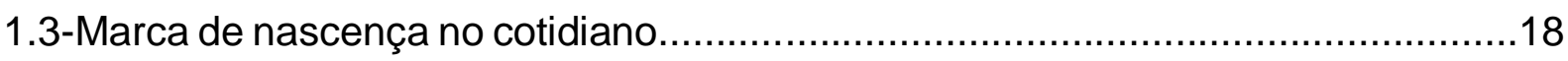

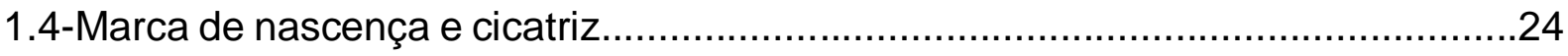

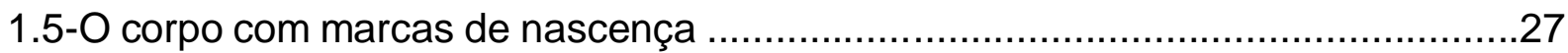

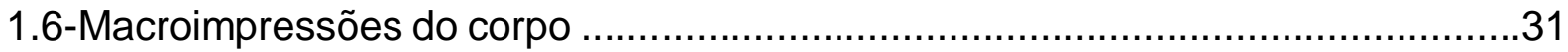

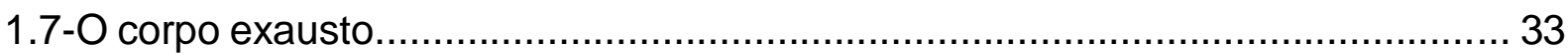

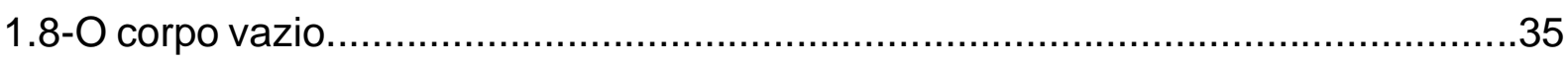

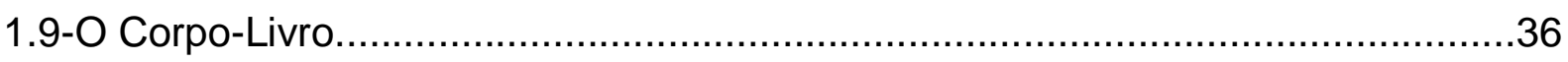

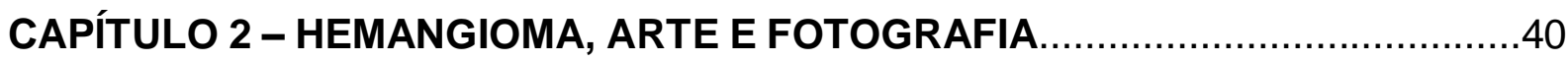

2.1-A marca de nascença e a ciência a partir do conto................................................40

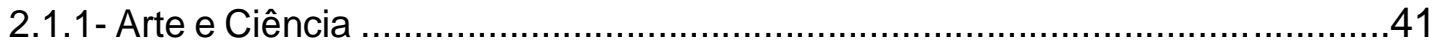

2.2-Abordagem médica da marca de nascença hemangioma....................................43

2.2.1 - Marcas de nascença ............................................................................ 43

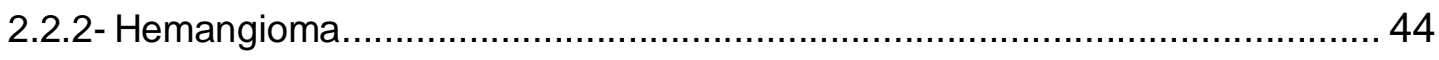

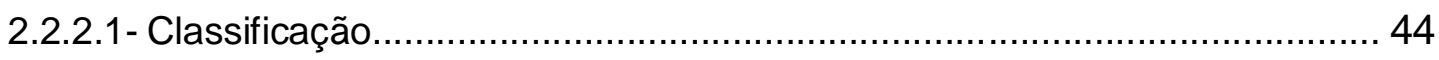

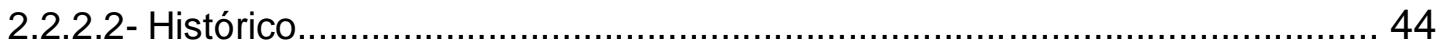

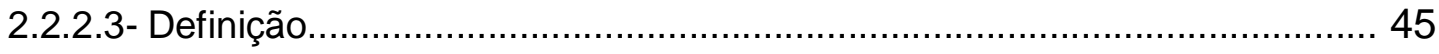

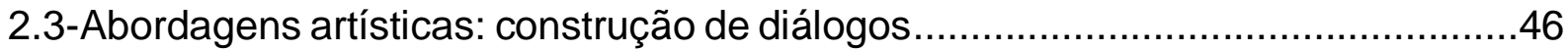

2.3.1 - O corpo e a recepção a partir da Arte Moderna …………………………........47

2.3.2- $\mathrm{O}$ corpo e as obras de arte ......................................................................52

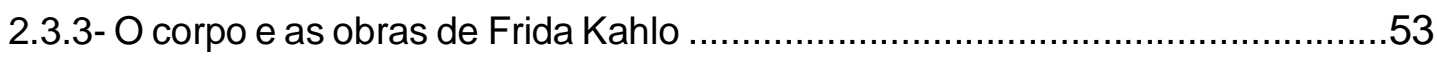

2.3.4- A marca de nascença no âmbito artístico .......................................................55 
2.4-Abordagens tecnológicas: construção de diálogos artísticos.

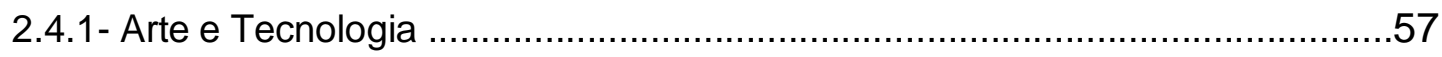

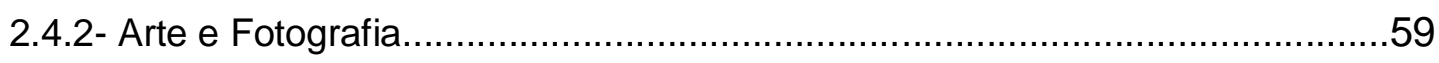

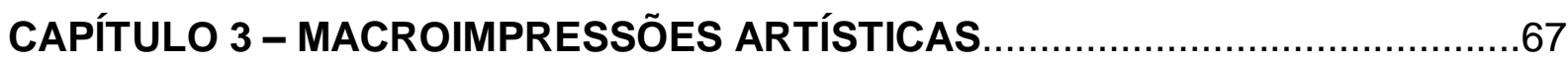

3.1-O hemangioma e sua poética nas produções artísticas......................................68

3.1.1 - A poética do nascimento do hemangioma..................................................68

3.1.2- A poética das formas e cores do hemangioma...............................................69

3.1.3- A poética das nuvens versus "desenhos venosos" ...........................................72

3.1.4- A poética do hemangioma-luz: nascimento das macroimpressões artísticas.. 73

3.2-Processo criativo das produções artísticas...................................................75

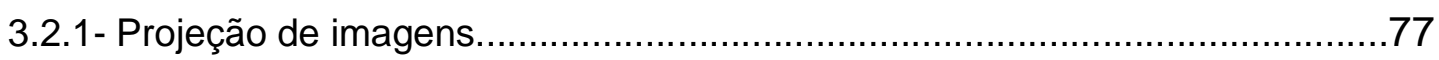

3.3-Apresentação das séries fotográficas: macroimpressões artísticas......................78

3.3.1- Produção: Fragmentos hemangescritos 1.................................................78

3.3.2- Poética: Fragmentos hemangescritos 1..................................................

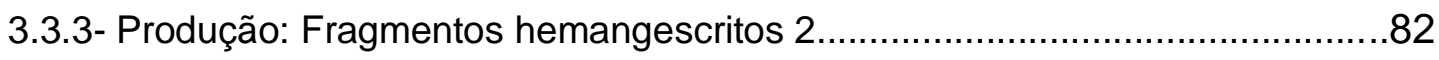

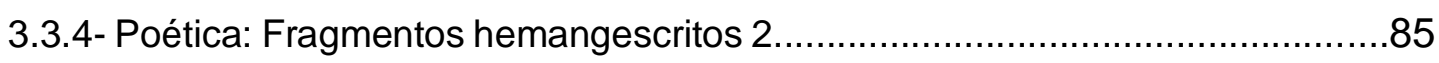

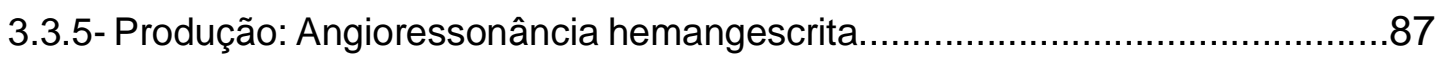

3.3.6- Poética: Angioressonância hemangescrita................................................90

3.3.7- Produção: Corporação hemangescrita................................................... 93

3.3.8- Poética: Corporação hemangescrita..............................................................

3.4-Corpos hemangescritos: macroimpressões artísticas- projeções-luz para um novo olhar 100

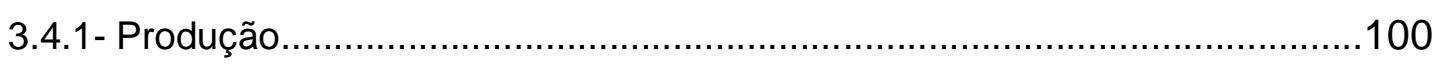

3.4.2- Poética: convergência de projeções..........................................................101

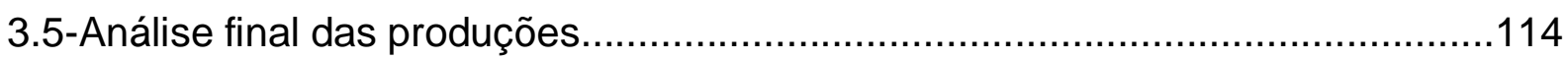

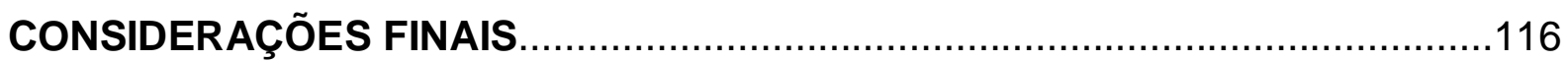

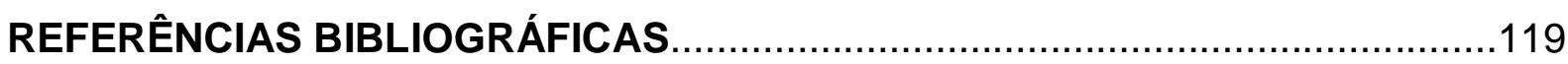

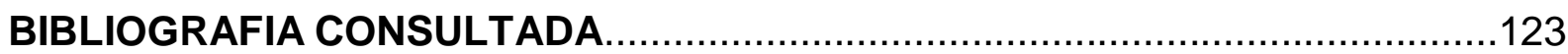

ANEXO 


\section{INTRODUÇÃO}

A temática que originou as experimentações artísticas desta pesquisa surgiu a partir de inquietações pessoais relacionadas ao nascimento, corpo, marcas, hemangioma, iluminação, fotografia e tecnologia. Essas primeiras conjecturas deram origem às novas abordagens que foram teorizadas e reflexionadas ao longo dos projetos desenvolvidos nas graduações em artes plásticas e artes cênicas, cursadas na UnB. Assim, com o intuito de dar prosseguimento a tais estudos, no âmbito acadêmico, propus-me a ingressar no mestrado e investigar o tema que foi sendo consolidado a partir da convergência das pesquisas anteriormente desenvolvidas, a saber: fotografia, corpo e hemangioma. O propósito deste passo baseou-se no entendimento de que o aprofundamento investigativo nas fundamentações teóricas relacionadas ao hemangioma, corpus desta pesquisa, pode nortear as análises e interpretações das proposições no campo das experimentações artísticas e tecnológicas.

O objetivo nesta pesquisa consiste em estudar, refletir e teorizar a respeito das possíveis construções e diálogos que a Arte pode mediar entre a marca de nascença denominada hemangioma e as possibilidades no campo fotográfico. Nesta proposta, a mediação fotográfica, os recursos da projeção no corpo suporte ${ }^{1}$, assim como a fusão das projeções de imagens, objetivam possibilitar que tanto os corpos suportes quanto o olhar do receptor possam imergir em construções artísticas que se propõem a projetar-se rumo a um novo olhar.

O problema gerado a partir das inquietações do tema refere-se ao acolhimento da marca de nascença hemangioma no campo artístico e fotográfico. Habitualmente, o tema hemangioma está voltado às investigações médicas, e sua abordagem artística é bastante precursora. A partir disso, surgiram os primeiros questionamentos que nortearam esta pesquisa: como o corpo com hemangiomas poderia desvincular-se da abordagem médica e adentrar no campo artístico? Como se daria a desconstrução do tema hemangioma a fim de que ele pudesse permitir uma nova roupagem? Seria possível seu diálogo com outras linguagens? Como o corpo com hemangioma seria acolhido no campo fotográfico?

\footnotetext{
${ }^{1}$ Neste contexto, o termo se refere ao corpo do indivíduo não acometido por marcas de nascença que servirá de suporte para a projeção das imagens do hemangioma. Em uma tentativa de exemplificação, pode-se afirmar que o corpo possui a mesma funcionalidade que uma tela exerce para um artista.
} 
Assim, com o intuito de aprofundar as pesquisas e reflexões a respeito dos questionamentos e abordagens do tema a presente dissertação foi organizada da seguinte maneira:

No primeiro capítulo, investigam-se as relações que o corpo estabelece com as marcas de nascença a partir da abordagem da obssesão pelo corpo "sem defeito" apresentado no conto The Birthmark (A marca de nascença) de Nathaniel Hawthorne ${ }^{2}$ que se torna o paradigma poético para a execução do trabalho. Isso porque os conflitos decorrentes de uma marca de nascença na protagonista do conto estabelecem diálogos com as fundamentações teóricas ao longo da pesquisa. No entanto, este estudo não tem o propósito de apresentar simplesmente os conflitos de um corpo acometido. Seu intuito é o de ampliar as discussões acerca do corpo, que traz consigo marcas que lhe imputam unicidade e que se tornam suas macroimpressões do corpo. Neste contexto, o estudo das abordagens filosóficas de Peter Pál Pelbart (2003), que se originam a partir da análise de personagens tais como Kafka e Bartleby, trouxe importantes refflexões sobre o corpo. A principal dessas abordagens diz respeito ao entendimento de um corpo singularizado pelos conflitos que o coage por dentro e por fora, e que é instigado a enveredar-se rumo à busca pelo signo de sua resistência. A abordagem do sociólogo Henri-pierre Jeudy (2002) do corpo trouxe reflexões a respeito da suscetibilidade do corpo de enxergar-se diferente. Nesse sentido, o olhar do outro desempenha um importante papel visto que ele instiga o outro a ver-se de outro modo.

No segundo capítulo, o paradigma poético a partir do conto The Birthmark (A marca de nascença) continua a contribuir com as construções do trabalho. As reflexões sobre o corpo com hemangiomas encaminham suas discussões rumo ao acolhecimento do tema no campo artístico. Por meio das abordagens de Lucrécia D`Aléssio Ferrara (2005) reflexiona-se sobre as possibilidades artísticas disponibilizadas por meio das transformações ocorridas na recepção da obra a partir do Modernismo. Nesse contexto, os trabalhos dos artistas Lygia Clark (1920-1988) e Robert Morris (1931) exemplificam as novas possibilidades de comunicação com o receptor. Em conformidade com essa perspectiva, Júlio Plaza (2003) pontua as novas relações entre autor-obra-recepção estabelecidas na contemporaneidade. Voltando-

\footnotetext{
${ }^{2}$ HAWTHORNE, Nathaniel. The Birthmark. In: Mosses From An Old Manse and Other Stories. Printed in Great Britain by Amazon.co.uk, Ltd. Marston Gate, 2014, p.1-10.
} 
se para as possibilidades de diágolos do tema no campo fotográfico, o estudo proposto por Silvio Zamboni (2006) é apresentado com o propósito de abordar as relações entre arte e ciência, ampliando, assim, as discussões entre arte e fotografia pontuadas por Annateresa Fabris (2008).

As investigações de Richard Dawkins (1998) a respeito da sofisticação do sistema do olho enquanto organismo biológico, num comparativo com a câmera fotográfica, ampliam as reflexões sobre o olhar. Nesse sentido, o processo fotográfico tratado por Philippe Dubois (2012) e Roland Barthes (1984) dão continuidade às referidas discussões. O trabalho do fotográfo Americano Davis Ayer ${ }^{3}$ apresenta composições fotográficas que trazem a interação entre os elementos fotográficos e artísticos, dentre os quais pode-se destacar o uso da projeção de imagens no corpo feminino.

No terceiro capítulo, as experimentações artísticas e fotográficas são protagonizadas pelo hemangioma. Ao longo do estudo teórico, as marcas de nascença foram entendidas como macroimpressões do corpo. Neste contexto, a proposta é que a macroimpressão hemangioma dialogue com as possibilidades criativas do campo artístico e fotográfico e produza macroimpressões artísticas. Assim sendo, primeiramente, propõem-se que os recursos de iluminação e a projeção do hemangioma integrados à criação fotográfica componham as construções artísticas da primeira etapa deste projeto. Como resultante desse processo, as fotografias advindas da projeção do hemangioma no corpo do outro buscam trabalhar novas posturas e/ou configurações e/ou possibilidades composicionais. Na segunda etapa, por meio da fusão entre as projeções das séries fotográficas anteriormente criadas, dá-se origem à série fotográfica "corpos hemangescritos". Essa produção surge a partir da concepção poética de que os corpos suporte "escritos" pelas projeções do hemangioma nas séries fotográficas anteriores se fundem e tornam-se corpos hemangescritos pela luz. Esta segunda etapa criativa pode ser entendida como uma extensão das possibilidades compositivas e artísticas iniciadas na primeira etapa.

\footnotetext{
${ }^{3}$ Nascido e criado em Austin, Texas, Davis Ayer iniciou seu trabalho com fotografias em 2007. Com conhecimentos em história da arquitetura e sob a orientação do fotógrafo de arquitetura Casey Dunn, logo foi inserido no mundo do cinema analógico com artistas como Steve Shore, Joel Sternfeld e Andreas Gursky. A partir de então, Ayer iniciou uma jornada de autodescoberta e experimentações que continuam visíveis em suas composições fotográficas até hoje. Atualmente, mora em Los Angeles embora seus trabalhos sejam produzidos em vários outros países. Cf. <http://www.davisayer.com>. Acesso em: 26 de abril de 2014. 23:05:18.
} 


\section{CAPÍTULO 1}

\section{CORPO E MARCAS DE NASCENÇA}

Com o objetivo de estudar as inter-relações entre o corpo, a marca de nascença e a tecnologia, proponho que as temáticas abordadas no conto do escritor $\mathrm{Na}$ thaniel Hawthorne ${ }^{4}$ intitulado The Birthmark (A marca de nascença) se torne o paradigma poético das construções propostas neste capítulo.

Primeiramente, o conto de Nathaniel Hawthorne apresenta o personagem Aylmer como um homem da ciência que dedicava-se aos estudos científicos, fazia uso da alquimia e possuía proficiência em todos os ramos da filosofia natural. Em meio à recente descoberta da eletricidade, Aylmer decide deixar seu laboratório aos cuidados de um assistente a fim de casar-se com a bela e amada Georgiana.

Logo após o casamento, Aylmer passa a enxergar a marca de nascença no formato de uma mão minúscula no rosto de sua esposa como uma imperfeição. Assim, acreditando ser a ciência um meio competente para solucionar tal acometimento, Aylmer propõe a retirada da marca de Georgiana. Ele explica para a esposa os reais riscos que a experiência científica poderia resultar, dentre eles, o risco de morte. Mesmo ciente de que isso poderia custar-Ihe a vida, a personagem autoriza a intervenção experimental em sua marca de nascença. Isso porque a aversão que Georgiana passa a nutrir por sua marca não permitiria que ela pudesse conviver com tal imperfeição o resto de sua vida.

Durante a experiência, após beber o elixir, Georgiana adormece enquanto Aylmer acompanha, em êxtase, o lento desaparecimento da marca de nascença em seu rosto. Ao acordar e olhar-se no espelho, Georgiana expressa seu contentamento com um leve sorriso ao verificar que a marca em seu rosto já parecia quase imperceptível. Entretanto, quando a marca finalmente parece desaparecer completamente de seu rosto, a vida de Georgiana também esvai-se.

\footnotetext{
${ }^{4}$ Nathaniel Hawthorne (1804-1864). Hawthorne, juntamente com Edgar Allan Poe, de quem era contemporâneo, foi um dos mestres iniciadores da short story norte-americana. E ainda como Poe ao escrever seus contos, usou uma idêntica técnica de unidade de efeitos" ou seja, a conexão entre o desenrolar das cenas e a criação de uma dada atmosfera, para que o desfecho, de antemão estudado, surja como uma cena que decididamente fira a sensibilidade do leitor. Uma técnica que, alicerçando a simbologia moral de Hawthorne, converteu cada um de seus contos numa fábula dramática. "Cf.", HAWTHORNE,1992.
} 


\subsection{A marca de Georgiana}

[..] Georgiana's lovers were wont to say that some fairy, at her birth hour had laid her tiny hand upon the infant's cheek, and left this impress there in token of the magic endowments that were to give her such sway over all hearts. Many a desperate swain would have risked life for the privilege of pressing his lips to the mysterious hand. It must not be concealed, however, that the impression wrought by this fairy sign manual varied exceedingly, according to the difference of temperament in the beholders. Some fastidious personsbut they were exclusively of her own sex-affirmed that the bloody hand, as they chose to call it, quite destroyed the effect of Georgiana's beauty, and rendered her countenance even hideous. But it would be as reasonable to say that one of those small blue stains which sometimes occur in the purest statuary marble would convert the Eve of Powers to a monster. Masculine observers, if the birthmark did not heighten their admiration, contented themselves with wishing it away, that the world might possess one living specimen of ideal loveliness without the semblance of a flaw. ${ }^{5}$

trecho do conto relata que a presença da marca de nascença no rosto da personagem Georgiana despertava várias conjecturas por parte das pessoas acerca dos possíveis motivos de tais acometimentos. Muitos especulavam desde os aspectos misteriosos e atrativos que envolviam tal marca até a destruição da beleza que aquela causava a uma jovem de tão bela aparência. Outros buscavam justificar a razão da marca na personagem por meio de crenças, mágicas e fantasias. A principal dessas fantasias dizia respeito ao toque de uma fada que, tendo colocado sua pequena mão sobre a bochecha do bebê Georgiana, deixara essa marca em sinal dos dons mágicos que estavam a dar-Ihe poder sobre todos os corações.

Em concordância com esse acontecimento, nas pesquisas sobre marcas de nascença, nota-se que as primeiras justificativas sem evidências científicas, relatadas no âmbito médico, também, apontam para as crenças populares como precursoras neste processo.

\footnotetext{
${ }^{5}$ HAWTHORNE, 2014, p.1-2.

Tradução do trecho: [..] Os admiradores de Georgiana costumavam dizer que alguma fada, na hora de seu nascimento, havia colocado a pequena mão sobre a bochecha do bebê, e deixou essa impressão em sinal dos dons mágicos que estavam a dar-lhe e que lhe daria poder sobre todos os corações. Certa vez, um pretendente desesperado teria arriscado a vida para ter o privilégio de apertar os lábios na misteriosa mãozinha. Entretanto, o que não podia ser ocultado era que a impressão do sinal presenteado pelas fadas variava muito, de acordo com a diferença de temperamento dos espectadores. Algumas pessoas mais exigentes, pessoas estas exclusivamente do sexo feminino, diziam que a mão sangrenta, como escolheram chamar, destruía o efeito da beleza de Georgiana, tornando seu semblante até mesmo horrível. No entanto, seria o mesmo que dizer que as pequenas manchas azuis que às vezes ocorrem no mais puro mármore de uma estatuária, converteria a estátua de Eva em um monstro. Para alguns observadores masculinos, se a marca de nascença não aumentava-lhes a admiração, contentava-Ihes o desejo que essa sumisse por achar que o mundo não pudesse possuir uma espécie viva de beleza ideal sem a aparência de uma falha. Tradutora: Juliana Rodrigues.
} 
Uma das principais crenças diz respeito à "impressão maternal"6. Segundo esse entendimento, a responsabilidade do acometimento das marcas de nascença em crianças era exclusivamente atribuído à figura materna. No caso de lesões vasculares congênitas, essa influência pode ser claramente percebida pelo reflexo das crenças populares na denominação nevus maternus, que significa marca de nascença materna.

Fig.1- Fada marcando bochecha de Georgiana. ${ }^{7}$

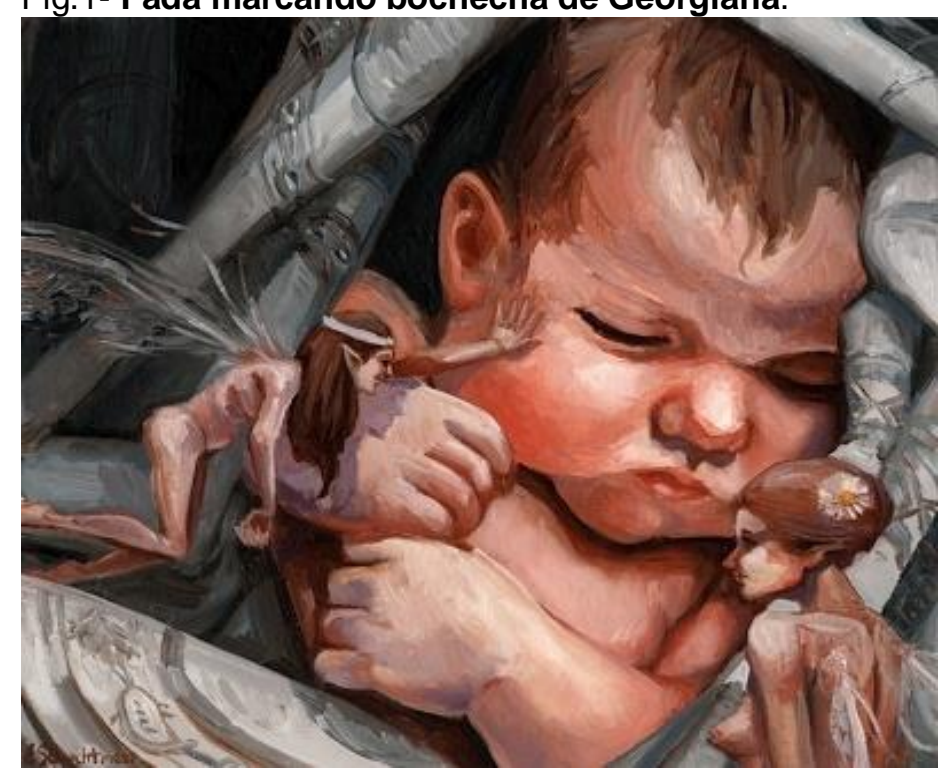

\subsection{Crenças populares e marca de nascença}

Sabe-se que, por um longo período, os acometimentos de marcas de nascença baseavam-se em mitos, misticismo e superstições populares. Dessa maneira, um vasto repertório informal de crenças e mitos foi sendo construído e, gradativamente, abrangendo as mais diversas culturas, povoados e comunidades locais. Por exemplo, na cultura Iraniana, acreditava-se que, se uma mulher tocasse sua barriga durante um eclipse solar, a criança seria acometida por uma marca de nascença. Em algumas culturas, marcas de nascença são consideradas presságios sobre a vida das pessoas supostamente relacionadas com formas de morte numa vida passada.

\footnotetext{
${ }^{6}$ Disponível em: <http://www.jornalciencia.com/saude/beleza/2324-os-mitos-e-os-misticismos-bizarros-por-tras-das-marcas-de-nascenca>. Acesso em: 07 mar. 2013. 22:10:11.

${ }^{7}$ Disponível em: <http://2.bp.blogspot.com/_R8LkKSvcN4c/TKCLXFkPpgl/AAAAAAAAXwg/ TKpQ9LbNN6g/s400/>. Acesso em: 10 jul. 2013.19:25:52.
} 
Outros exemplos de crenças populares ${ }^{8}$ podem ter suas justificativas descritas da seguinte maneira:

a) Cores dos alimentos - A mãe que não tivesse o seu "desejo alimentar" atendido durante a gestação originaria manchas, na cor do alimento desejado, na pele do bebê. Por exemplo, o aparecimento de marcas marrons no bebê que teriam sido causadas porque a mãe havia desejado comer chocolate e não havia realizado o seu desejo. Sabe-se, ainda, que, durante a gravidez, as mães eram proibidas de comer certas frutas, principalmente, vermelhas ou certos tipos de alimentos. Essa prática originou os termos que adjetivavam o aspecto de algumas lesões, tais como morango, framboesa, dentre outros.

b) Sentimentos - Emoções extremamente fortes vividas durante o período da gravidez imprimiriam manchas no corpo da criança. Normalmente, essa marca acometeria a região específica que a mãe estava tocando enquanto a emoção estava sendo vivenciada.

c) Contato com a pele - Durante o período de gravidez, a mãe não poderia guardar objetos em seus seios, pois o contato dos objetos com a pele materna resultaria em manchas no bebê.

d) Parto - Complicações no parto, tais como "a criança ter passado da hora de nascer" poderiam ocasionar manchas de nascença.

\subsection{Marca de nascença no cotidiano}

Dentre os vários significados designados ao termo "marca" pelo dicionário, primeiramente, faremos uso daquele que se refere a um sinal natural na pele de uma pessoa ou no pelo de um animal.

Sabe-se que existe uma grande diversidade de marcas de nascença em nossa atualidade, e que estas podem variar em seus muitos aspectos, tais como: tamanho, forma, cor, textura, relevo, profundidade, características constitutivas, dentre outros. O resultado da combinação dessas características na pele define, de maneira singular, a aparência das marcas de nascença em cada indivíduo, pois, apesar da medicina ter ampliado seu conhecimento a respeito das reais causas das marcas de

\footnotetext{
${ }^{8}$ Os exemplos das crenças populares descritas neste trecho foram obtidas a partir de entrevistas, realizadas por mim, com pessoas cujo primeiro conhecimento a respeito da origem das marcas de nascença foi transmitido via oral, por seus antepassados.

${ }_{9}$ Dicionário Eletrônico Houaiss da Língua Portuguesa 3.0.
} 
nascença, ainda hoje, muitas particularidades acerca de tais acometimentos continuam sem explicação científica.

Popularmente conhecida como, "sinal", "pinta" ou "marca de nascença", diferentemente do que muitos acreditam, a incidência de marcas de nascença não ocorre de maneira tão rara e isolada como se imagina, ainda mais se levamos em consideração o fato de que muitas marcas de nascença não são relatadas. Isso ocorre porque elas são entendidas como acometimentos puramente estéticos, uma vez que não necessitam de intervenção médica. Assim, partindo desse entendimento, pode-se afirmar que uma grande parte da população possui algum tipo de marca em seu corpo desde o nascimento, embora muitas incidências não sejam notadas e/ou relatadas.

Algumas marcas de nascença acometem gerações inteiras e são chamadas de "marcas de família". Nesse caso, muitas delas são conhecidas apenas por seu possuidor, e partilhada de maneira bastante seletiva com membros da família, amigos, entre outros.

Por outro lado, outras marcas podem ganhar ampla visibilidade popular quando associadas a pessoas de grande repercussão midiática. Nesse sentido, podem-se apontar alguns exemplos de personalidades que possuem marcas de nascença.

$\mathrm{Na}$ figura 2, encontra-se a pinta popularmente conhecida da atual apresentadora de televisão Angélica Ksyvickis e sua boneca ${ }^{10}$.

Fig.2 - Angélica Ksyvickis e boneca. ${ }^{11}$

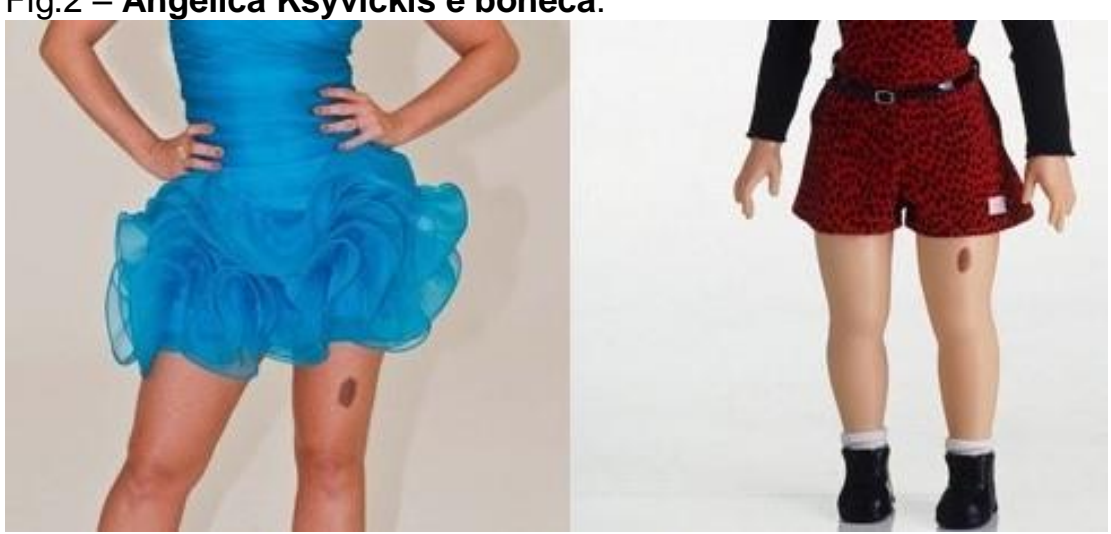

Fonte: Divulgação/Mario Llaguno (atualizado em 2013) c/ adaptações.

\footnotetext{
${ }^{10} \mathrm{Em}$ 1989, a Estrela lançou a boneca da Angélica reproduzindo sua "marca registrada": a pinta em sua coxa esquerda. Cf. <http://propagandasdegibi.wordpress.com/2012/05/27/boneca-angelica-1989>. Acesso em: 07 de mar. 2014.18:10:30.

${ }^{11}$ Disponível em: <http://m.mdemulher.abril.com.br/tv-novelas-famosos/famosos-seus-bonecos759623>. Acesso em: 26 mar. 2014.18:25:55.
} 
Outra personalidade bastante conhecida por sua marca de nascença é o expolítico e estadista Russo Mikhail Sergueievitch Gorbachev (fig.3) acometido por um hemangioma plano na testa na cor carmesim conhecido como mancha vinho-doporto $^{12}$. Sabe-se que, dentre as várias situações vivenciadas por esse personagem em sua vida política, sua marca de nascença na testa foi uma temática amplamente explorada e divulgada na mídia, bem como, trabalhada por cartunistas.

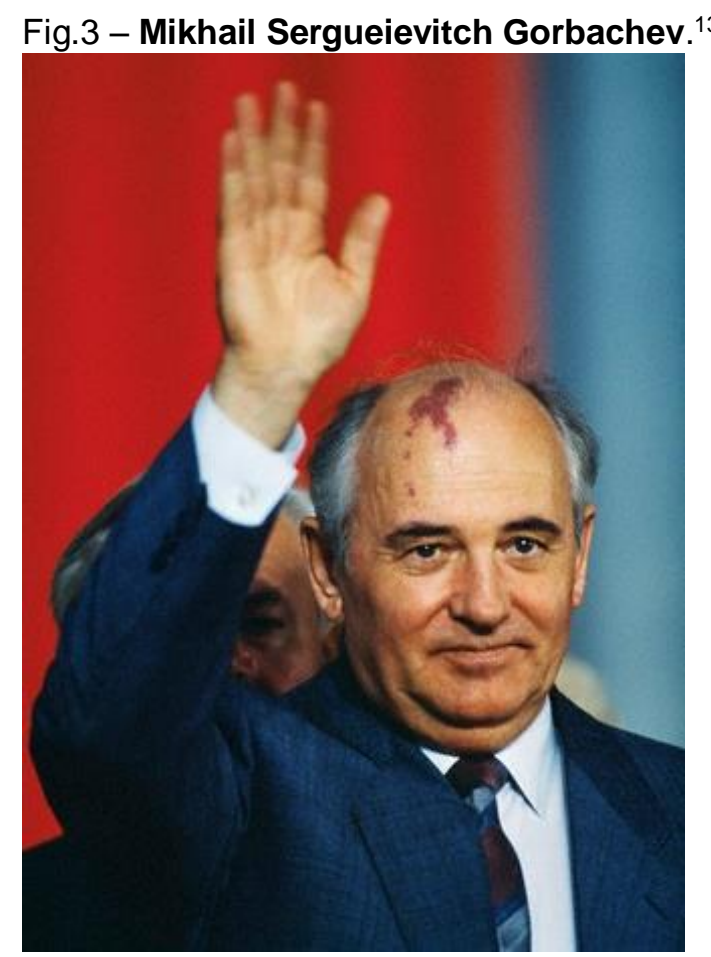

Fonte: Terry Wilson, National News, 2012.

A figura 4 apresenta a atriz e escritora Graziella Moretto cuja marca de nascença no rosto vincula-se as causas junto a Associação Brasileira das pessoas com Hemangioma e Linfangiomas - ABRAPHEL ${ }^{14}$, da qual ela é madrinha e colaboradora.

\footnotetext{
12 "Os hemangiomas planos, também conhecidos como 'Manchas Vinho-do-Porto' (Port Wine Stain), sempre surgem ao nascimento como manchas de pele que podem variar da cor rosada até o vermelho escuro [...] Durante a infância, esses hemangiomas persistem como manchas planas, sem relevo. A partir da segunda década de vida, dois terços dos casos passam a sofrer alterações que podem promover deformidade ao longo do tempo [...]" (CAMPOS, online). Disponível em:

<http://www.heloisacampos.com.br/website>. Acesso em: 10 maio 2012. 23:15:20.

${ }^{13}$ Disponível em: <http://canadianawareness.org/wp-content/uploads/2012/11/gorbachev.jpg> Acesso em: 26 mar. 2014.18:30:24.

${ }^{14}$ Sem fins lucrativos, a ABRAPHEL é uma organização formada por pacientes e familiares de pessoas com hemangiomas e linfangiomas. Seu principal objetivo é difundir conhecimentos sobre o assunto entre profissionais da saúde e sociedade em geral, buscando ainda organizar ações que favoreçam o acesso dos pacientes às informações e tratamento adequado no País. Cf. <www.Abraphel.org.br>. Acesso em: 10 maio 2012. 22:05:02.
} 
Fig. 4- Graziella Moretto. ${ }^{15}$

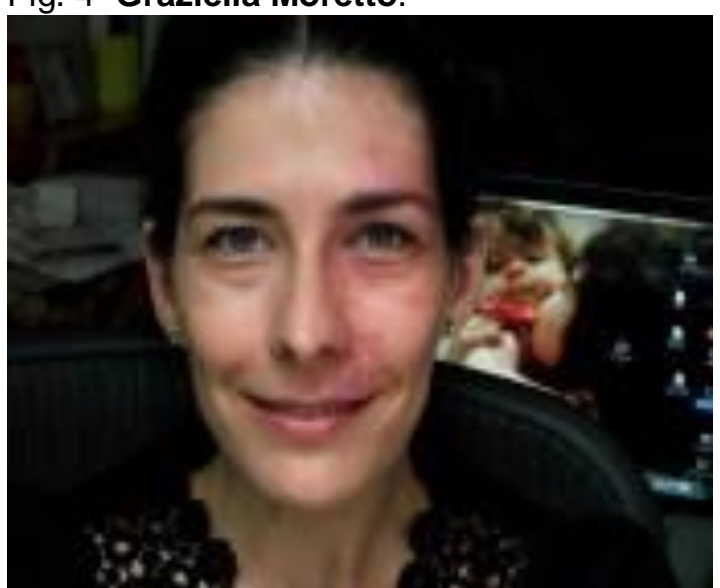

Fonte: Divulgação/ Abraphel.

As marcas operam como índice, ou melhor, as marcas parecem incorporar-se à imagem das pessoas, estabelecendo, assim, uma relação indissociável entre a marca e a pessoa. Desse modo, o processo metonímico estabelecido nesta relação possibilita que a visualização da marca evoque imediatamente a imagem da pessoa a ela associada.

Retomando a análise do termo marca ${ }^{16}$, nota-se que o seu significado estende-se a um sinal natural na pele que também pode acometer o pelo de um animal. A partir desta afirmação, podemos salientar que os animais que possuem tais sinais de nascença, assim como nos seres humanos, são dotados de características raras e únicas que os distinguem de todos os demais.

Um grande exemplo dessa afirmação pode ser encontrada nas "marcas" que caracterizam certas espécies de animais, tais como: os cães dálmatas, as girafas, as zebras, dentre outros, pois, apesar dessas "marcas" caracterizarem algumas espécies de maneira coletiva, elas não seguem um "padrão" de completa igualdade. Assim, a partir desta conjectura, pode-se entender que mesmo as "marcas coletivas" podem apresentar-se de maneira singular em cada um dos animais acometidos.

\footnotetext{
${ }^{15}$ Disponível em: <www.Abraphel.org.br>. Acesso em: 10 maio 2012. 22:10:48.

${ }^{16}$ Sinal natural na pele de uma pessoa ou no pelo de um animal. Fonte: Dicionário Eletrônico Houaiss da Língua Portuguesa 3.0.
} 
Fig. 5- Vaca Moisés. ${ }^{17}$

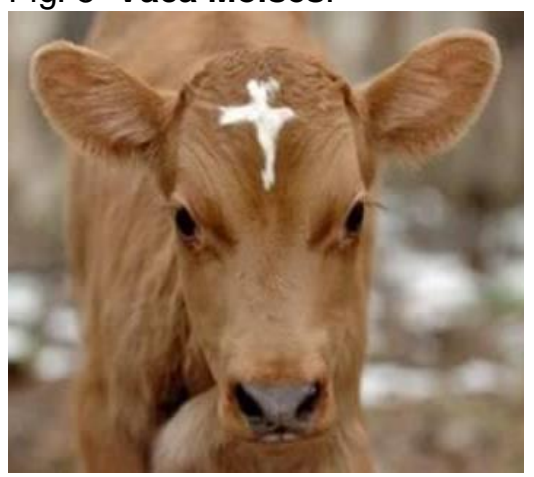

Foto: Reprodução/Telegraph, com adaptações.
Fig.6- Dálmata Zeus. ${ }^{18}$

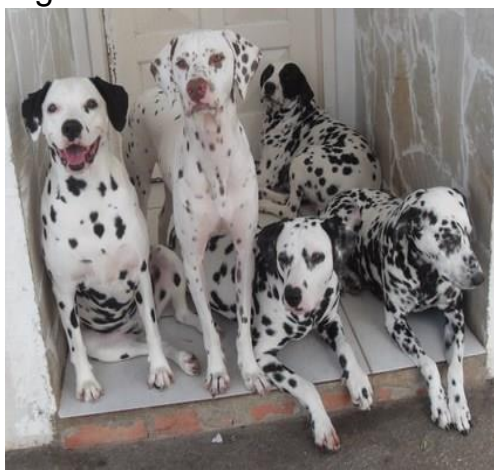

Foto: Divulgação/ Arca de Noé.

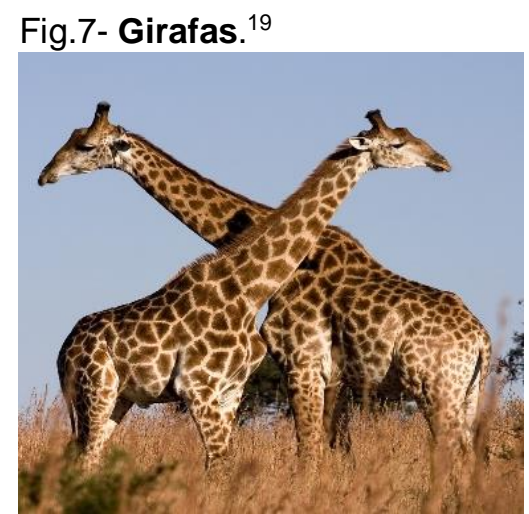

Foto: Galeria de FotosWiki.org.

Ampliando ainda mais o campo de abordagem a respeito das marcas em nosso cotidiano, percebe-se que uma grande diversidade de acometimentos também pode ser encontrada nos elementos da natureza. Observa-se, ainda, que a maioria das marcas encontradas em árvores, pedras e tantos outros elementos na natureza são resultantes da ação do homem, do tempo, de pragas ou inúmeros outros fatores. No entanto, é importante salientar que a aproximação proposta neste tópico restringese apenas às semelhanças estéticas, visto que a natureza de tais marcas não pode ser equiparada.

Por exemplo, as manchas na árvore, acometimento de pulgão ${ }^{20}$, encontrada na figura 8 , assemelham-se esteticamente às marcas de nascença denominadas "hemangiomas planos" conhecidos como vinho-do-porto.

\footnotetext{
17 Disponível em:

<http://i1.r7.com/data/files/2C92/94A3/2560/828C/0125/7369/1666/6C01/bezerro-m-20091209.jpg> Acesso em: 26 mar. 2014. 23:08:55.

${ }^{18}$ Disponível em:

<http://arcadenoe.sapo.pt/img/album/88/424788_sou_o_dalmata_diferente_img.jpg> Acesso em: 26 mar. 2014. 23:15:38.

${ }^{19}$ Disponível em: <http://www.fotoswiki.org/foto/duas-girafas-jpg>

Acesso em: 26 mar. 2014. 23:20:15.

${ }^{20}$ Pulgão é o termo popularmente conhecido. Na biologia, "os afídeos ou piolhos das plantas são insetos sugadores fitófagos, de comprimento geralmente entre 2-3 mm, alimentando-se, conforme espécie, nos vértices vegetativos, nas folhas, nas raízes, no colo radicular, no caule e, mais raramente, nas flores e frutos". "Cf.", ILHARCO,1992, p.127.
} 
Fig. 8 - Árvore com manchas. ${ }^{21}$

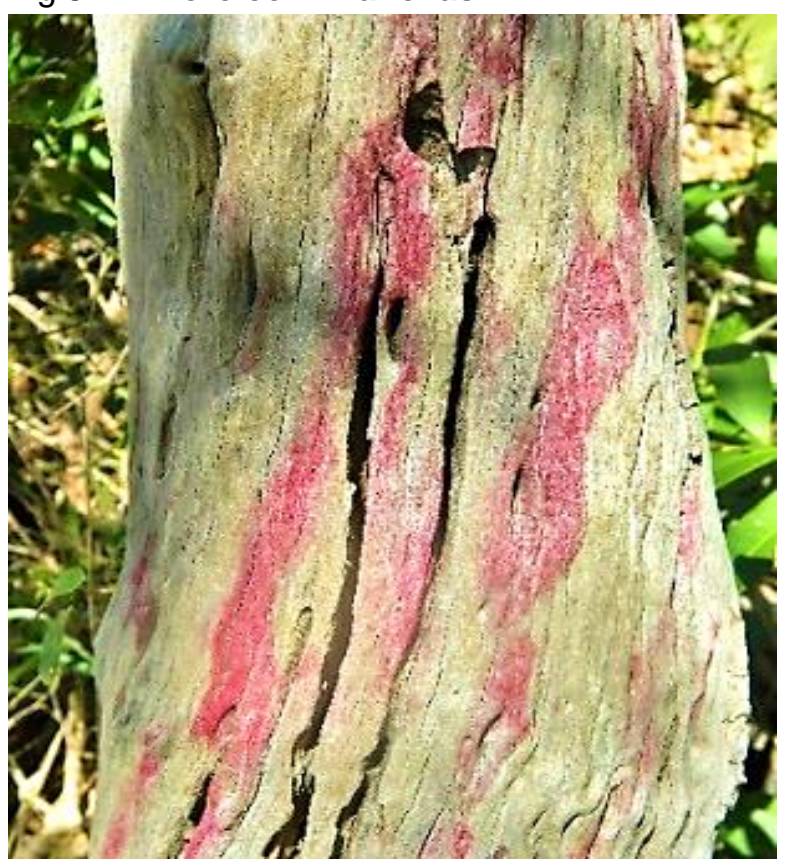

Foto: Tatiana Rodrigues.

$\mathrm{Na}$ figura 9, observam-se manchas na pedra cujas colorações se aproximam dos acometimentos das marcas de nascença denominadas "hemangiomas cavernosos". ${ }^{22}$

\section{Fig. 9 - Pedra com manchas. ${ }^{23}$}

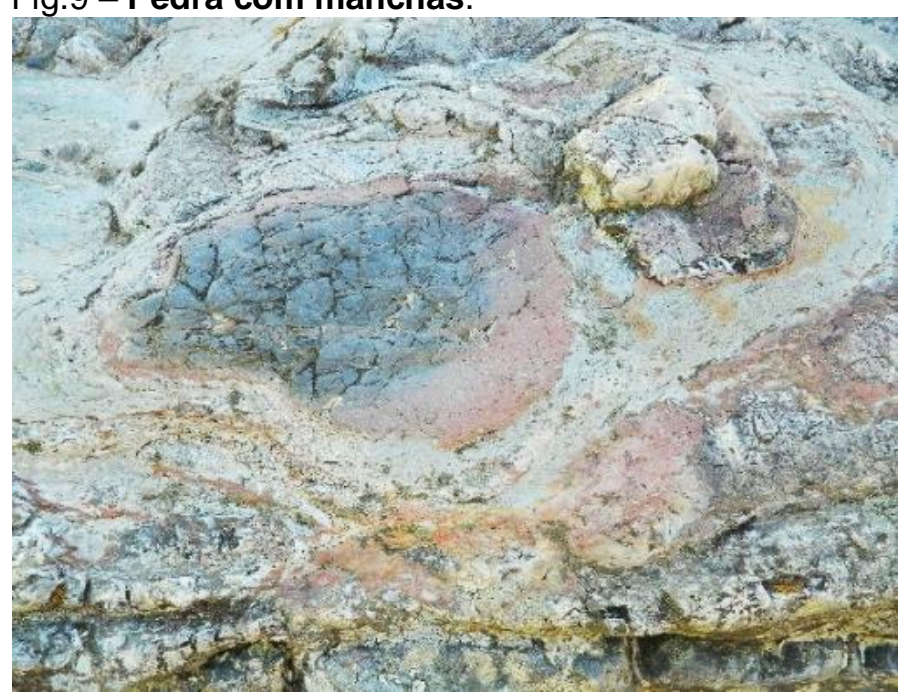

Foto: Tatiana Rodrigues.

${ }^{21}$ Local: Parque Nacional, Chapada dos Veadeiros -GO. Data:19 nov. 2013.

${ }^{22}$ Os hemangiomas cavernosos são más-formações da rede vascular sanguínea, venosa ou arteriovenosa. São visualizados como formações compostas por capilares ou veias dilatadas. Conforme profundidade, sua coloração pode variar entre os tons do roxo até o vermelho escuro.

Disponível em: <http://www.heloisacampos.com.br/website>. Acesso em: 10 maio 2012. 23:25:20.

${ }^{23}$ Local: Parque Nacional, Chapada dos Veadeiros -GO. Data:19 nov. 2013. 


\subsection{Marca de Nascença e cicatriz}

Fig.10 - Marcas de Superação. ${ }^{24}$

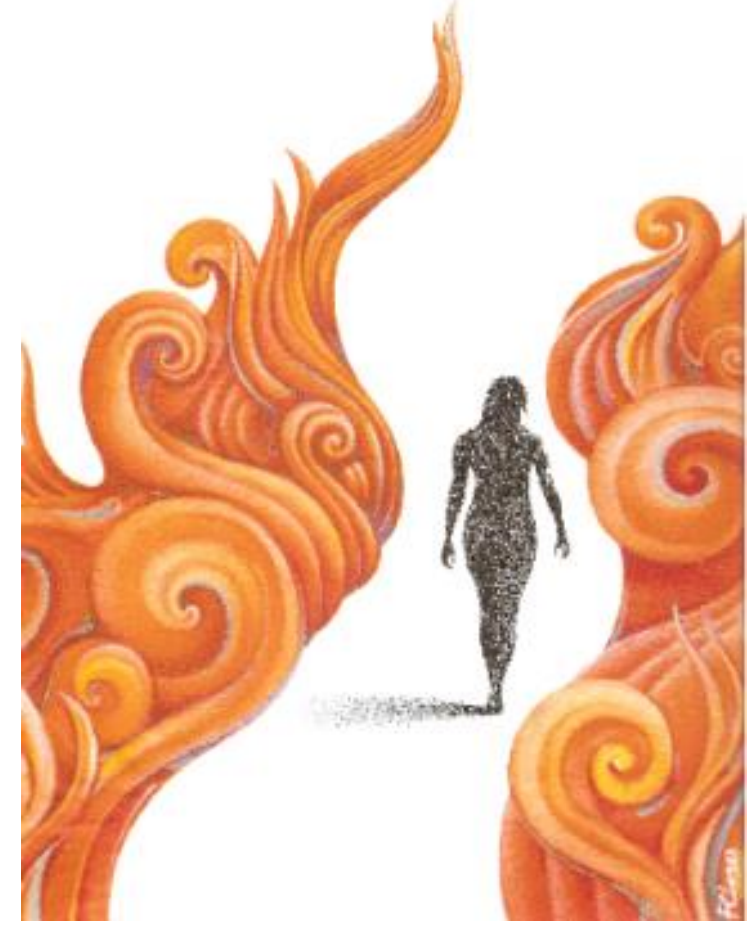

Ilustração: F. C. Lopes. Capa, c/ adaptações.

Marcado de um modo quase sempre irreversível, o corpo acometido por queimaduras torna-se vítima de um dos meios mais atrozes de afetação corporal. Nesse contexto, o fogo pode ser apontado como o grande responsável pela maioria dos incidentes. De maneira avassaladora, as queimaduras provenientes do fogo não deformam apenas o corpo-matéria; por vezes, as marcas emocionais as sobrepujam. As cicatrizes são profundas e, muitas vezes, tornam-se piores em meio às duras etapas que o vitimado precisará enfrentar. Em casos muito graves, a primeira grande luta será pela sobrevivência, e, logo depois, a etapa de aceitação e adaptação às formas adquiridas por seu "novo corpo". Maria Thereza Piccolo ${ }^{25}$ (2011, p. 25) afirma que "quem passou por uma grande queimadura jamais será o mesmo". Portanto, é fundamental que tanto o paciente quanto a família recebam suporte emocional por meio de um acompanhamento psicológico a fim de auxiliá-los no processo de aceitação.

\footnotetext{
${ }^{24}$ Fonte: Revista do Correio. Correio Brasiliense. Domingo, 1 de maio de 2011, ano 6, número 311.

${ }^{25}$ A médica Maria Thereza Piccolo é uma das chefes do Instituto Nelson Piccolo em Goiânia. O referido hospital é especializado em atendimentos a queimados e tem sua filial em Brasília. Cf. DUARTE, Flávia. Cicatrizes difíceis de curar. In: Revista do correio-Marcas de Superação. Correio Brasiliense. Brasília, $1^{\circ}$ de Maio de 2011, ano 6, n.311, p. 25.
} 
O processo de cicatrização é talvez o pior desafio físico a ser enfrentado, pois a pele queimada, considerada morta, precisa ser arrancada e descartada. Assim, o procedimento de limpeza e retirada da pele e cascas torna-se um processo de sofrimento diário. $\mathrm{O}$ chamado desbridamento ${ }^{26}$, realizado nas feridas das vítimas, arranca muito mais do que a pele necrosada, uma vez que a retirada definitiva da antiga pele parece afastar cada vez mais as possibilidades do indivíduo reaver o seu "antigo corpo". E, no final, ainda restarão as cicatrizes. O autor refere-se à cicatriz como um elemento de horror ou uma marca de honra.

A pele já é escrita. Seus traços, suas marcas, suas cicatrizes, suas rugas tanto são sinais visíveis e palpáveis que revelam toda a ambiguidade da apercepção do corpo. Morto ou envelhecido, o corpo não se torna por isso mais feio; é a escrita natural da pele que confere a possibilidade de uma estetização que o tempo não saberia destruir. A cicatriz pode ser um elemento de horror ou uma marca de honra (JEUDY, 2002, p.85).

A partir desse trecho, é possível estabelecer uma analogia com o conto $A$ marca de nascença. Baseando-se nas definições do autor quanto à pele inscrita, pode-se concluir que a marca de nascença no rosto de Georgiana era sua primeira e principal escrita natural da pele. Sendo assim, sua marca de nascença não deveria tornar o seu corpo, por isso, mais feio, mas deveria tornar-se um elemento singular e, portanto, um elemento de honra e não de horror.

A cicatriz como elemento de horror, também, apresenta-se em uma outra etapa vivenciada pela pessoa acometida por queimaduras, pois, quando todas as etapas parecem ter sido superadas, o retorno da pessoa ao seu cotidiano, muitas vezes, apresenta-Ihe um desafio ainda maior: lidar com o horror, o espanto, a repulsa e rejeição que suas cicatrizes causam no outro.

Jeudy (2002, p.85) define a cicatriz como uma marca súbita, uma marca do destino que parece anular o idealismo de beleza baseado na integridade do corpo, representada pela superfície lisa da pele. Explicita também que o denominado horror do desastre ocorre em decorrência dela se tornar um sinal pessoal, uma espécie de

\footnotetext{
${ }^{26} \mathrm{O}$ desbridamento é um procedimento que consiste na retirada de tecidos desvitalizados ou necrosados aderidos ou de corpos estranhos (partículas) no leito da ferida, usando técnicas mecânicas e/ ou químicas. Fonte: Dicionário Eletrônico Houaiss da Língua Portuguesa 3.0.
} 
sinal exclusivo do ego para o acometido. E, por essa razão, é que é tão importante que o olhar do outro não seja de reprovação.

Ao retomar o conto A Marca de nascença, nota-se que a personagem Georgiana também enfrentou sérios conflitos com relação à falta de aceitação das pessoas devido a sua marca de nascença no rosto, porque, assim como as cicatrizes que acometem o corpo de quem sofre queimaduras, o pior enfrentamento para quem possui uma marca é a estigmatizacão do outro.

Segundo Ribas (1994, p.16), toda pessoa considerada fora das normas e das regras estabelecidas é uma pessoa estigmatizada. Em sentido inverso, afirma que o estigma não está na pessoa, mas ele surge em decorrência dos valores culturais estabelecidos. E são esses valores culturais que permitem identificar quais pessoas serão estigmatizadas. Com relação a uma pessoa estigmatizada por ter deficiência, o autor afirma que uma pessoa traz em si o estigma social da deficiência. Contudo, é estigmatizada porque se estabeleceu que ela possui, no corpo, uma marca que a distingue, pejorativamente, das outras pessoas.

Aplicando esse entendimento à Georgiana, pode-se afirmar que a personagem carregava em si o estigma social da marca de nascença. Essa relação se aplicava de maneira ainda mais severa à personagem, uma vez que sua marca não era apenas subjetiva; ela estava estampada em seu rosto e, por isso, estigmatizada. Para o autor, as pessoas estigmatizadas são pessoas que, muito embora tenham sido criadas nesta sociedade e nesta cultura, não são reconhecidas nem por esta sociedade, nem por esta cultura.

Ribas (1994, p.16) aponta uma divisão estrutural da nossa sociedade em classes sociais que colocam os considerados "iguais" em um polo da sociedade e os considerados "diferentes" em um outro. E esta divisão, uma vez introjetada ${ }^{27}$ como se fosse natural, faz com que muitos dos considerados "diferentes" aceitem tanto a condição de "diferentes" quanto a de "inferiores".

Assim, entende-se que a condição assumida por Georgiana fez com que ela, segundo os padrões da sociedade vigente, se afastasse cada vez mais da condição de "normalidade". De acordo com Ribas (ibid.), a pessoa que é colocada à parte da

\footnotetext{
${ }^{27}$ O termo introjeção foi utilizado em seu sentido sociológico que pode ser entendido como o processo por meio do qual uma pessoa incorpora a seu pensamento valores de outras pessoas ou grupos. Fonte: Dicionário Eletrônico Houaiss da Língua Portuguesa 3.0.
} 
sociedade é aquela que foge dos "padrões" e, de certa forma, agride a "normalidade".

Para esse autor:

No conjunto dos valores culturais que definem o indivíduo "normal", estão incluídos "padrões" de beleza e estética voltados para um corpo esculturalmente bem-formado. [..] É por isso que se procura alcançar por qualquer meio e a qualquer preço estes "padrões. (RIBAS, 1994, p.18).

Em oposição aos "padrões” de beleza da sociedade, Georgiana trazia a marca do desconhecido, do inesperado, do repulsivo, do misterioso, do fantasioso, do pecaminoso, da curiosidade, da impureza, da singularidade, da ambiguidade, das sensações, das percepções, das fruições e segredos que muitos desejavam desvelar e/ou arrancar.

\subsection{0 corpo com marcas de nascença}

No conto A marca de nascença, o acometimento no rosto da personagem Georgiana é descrito da seguinte maneira:

[..] in the centre of Georgiana's left cheek there was a singular mark, deeply interwoven, as it were, with the texture and substance of her face. In the usual state of her complexion-a healthy though delicate bloom-the mark wore a tint of deeper crimson, which imperfectly defined its shape amid the surrounding rosiness. When she blushed it gradually became more indistinct, and finally vanished amid the triumphant rush of blood that bathed the whole cheek with its brilliant glow. But if any shifting emotion caused her to turn pale there was the mark again, a crimson stain upon the snow, in what Aylmer sometimes deemed an almost fearful distinctness. Its shape bore not a little similarity to the human hand, though of the smallest pigmy size. ${ }^{28}$

\footnotetext{
${ }^{28}$ HAWTHORNE, 2014, p.1. Tradução do trecho: [..] no centro da face da bochecha esquerda de Georgiana, havia uma marca singular, profundamente entrelaçada, por assim dizer, com a textura e a substância de seu rosto. No estado normal, — um aflorar saudável apesar de delicado — a marca tinha um tom do mais profundo carmim, que imperfeitamente definia sua forma em meio à vermelhidão ao redor. Quando Georgiana corava, gradualmente a marca tornava-se mais discreta e finalmente desaparecia em meio à pressa triunfante de sangue que regava a face com seu brilho resplandecente. Mas se qualquer alteração em suas emoções a fazia empalidecer, a marca aparecia novamente, uma mancha vermelha sobre a neve, na qual Aylmer, às vezes, considerava uma distinção quase temerosa. Sua forma não carregava semelhança com uma pequena mão humana, apesar do tamanho de pigmeu. Tradutora: Juliana Rodrigues.
} 
Fig.11- A marca de nascença de Georgiana. ${ }^{29}$

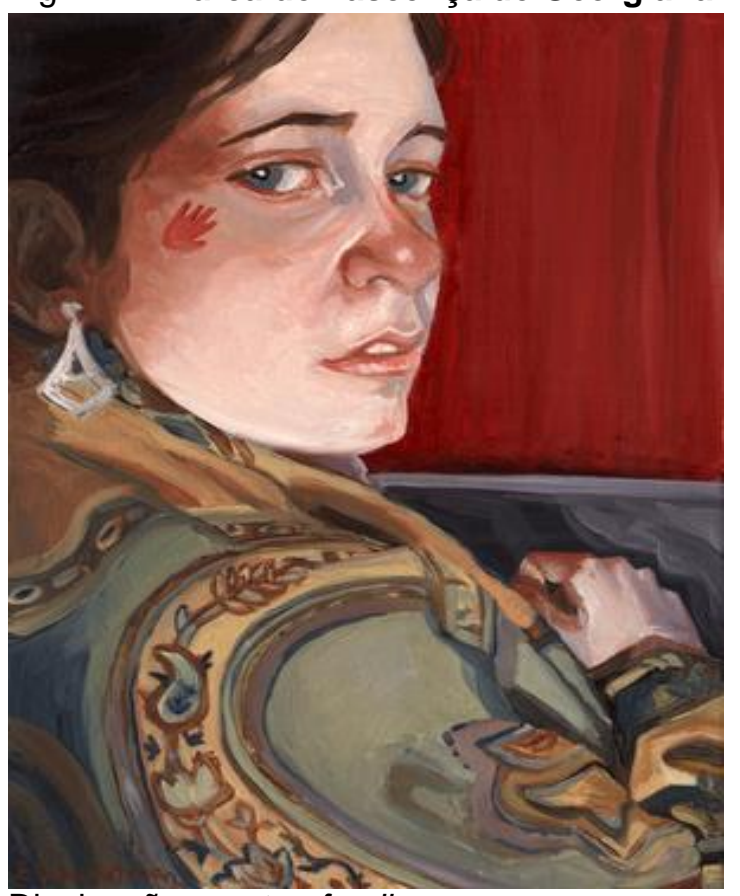

Divulgação: onetruefamily.

O corpo marcado dificilmente é desapercebido ao olhar do outro, e, assim como na descrição do acometimento de Georgiana, o olhar parece querer captá-los com riqueza de detalhes. Encontramos pessoas acometidas por marcas nas mais variadas ocasiões do cotidiano: ao atravessar uma rua, numa troca de olhares casual em estabelecimentos comerciais, no trabalho ou em tantas outras situações. Entretanto, quando isso acontece, o "diferente" parece exercer uma espécie de "poder" sobre nosso olhar. Em sua explicação a respeito do corpo-texto, Jeudy (2002, p.84) afirma que, por poder tornar-se um texto, a pele confirma o fato de uma exibição involuntária. Portanto, as proezas desenvolvidas para disfarçar essa fatalidade de uma revelação provam que esse modo de exibição não é procurado, que ele se impõe ao olhar e parece dizer sempre demasiado em relação ao que imaginamos ser. Seria portanto a exibição involuntária da pele que se impõe ao olhar uma pista a respeito do olhar do outro sobre o corpo com marcas de nascença?

Jeudy (loc.cit.) traz ainda que a pele, tal qual um texto que se escreve sozinho, nos trai, e a vontade de não ocultar nada ao olhar do outro, não hesitando em mostrar os traços nela escritos pelo tempo e pelos efeitos da decrepitude, só faz confirmar o poder irresistível dessa exibição. A partir dessas considerações, pode-se afirmar que,

29 Disponível em: <http://sambrinegarcompii.files.wordpress.com/2013/01/becky-birthmark2.png> Acesso em: 10 jul. 2013.19:45:30. 
muitas vezes, o poder de exibição da pele parece opor-se à nossa vontade, uma vez que a pele insiste em revelar-se ao olhar do outro. Nesse sentido, entende-se que a pele com marcas de nascença nos trai de uma maneira ainda mais severa. Isso porque, em geral, o indivíduo com marcas de nascença no corpo parece querer ocultarse ao olhar do outro.

Em meio a essa contrariedade, ocultar-se versus revelar-se, da pele com marcas de nascença, pode-se afirmar que o olhar do outro é que se impõe? Ou seria a pele com marcas de nascença que se impõe ao olhar? Independentemente de qual seja a assertiva, sabe-se que o olhar do outro estabelece uma intrínseca relação com o corpo com marcas de nascença. Assim, o olhar do outro curioso, impactado, penalizado, solícito e nutrido pelos mais variados sentimentos não parecem simplesmente observar; ele parece fixar-se sobre os corpos marcados pelo desconhecido. Assim, questiona-se: seria o envolvimento desse corpo com o desconhecido ou seria o 'corpo estranho' o motivador do inexplicável fascínio do olhar do outro pelo corpo marcado? Nessa perspectiva, a definição de corpo estranho amplia ainda mais essa discussão. Jeudy (2002, p.102) define o corpo estranho como um corpo que se presta a todas as fantasias que suscitam a atração e repulsão. Assim, o corpo estranho pode ser idealizado como a expressão de uma beleza inacessível e/ou rejeitado como o símbolo que objetiva os sinais de repulsa.

Em sua definição para 'corpo estranho', nota-se que Jeudy (loc.cit.) apresenta um corpo que pode ser tanto idealizado quanto rejeitado. No entanto, a afirmação do autor de que o corpo estranho se presta a todas as fantasias que lhe for submetido nos aproxima de algumas afirmativas. Se considerarmos o fato de que as fantasias do outro poderão atribuir valores ao corpo estranho, pode-se afirmar que o olhar é o responsável pela exteriorização do valor escolhido, seja ele atração ou repulsão. Talvez, seja essa a razão pela qual o olhar do outro mostra-se tão atento.

O olhar do outro parece motivado por uma curiosidade quase inexplicável pelo corpo marcado. E, neste sentido, ao tornar-se incansavelmente obstinado, ele inspeciona, esmiúça, analisa. Quando encontra um ângulo de observação ao qual se certifica que não poderá ser notado, esse olhar insiste em deter-se. Ele não se propõe simplesmente a olhar, mas parece imergir na estranheza que circunda tal acometimento. Portanto, o olhar sobre o corpo do outro, mesmo que inconscientemente, intenta desvendar não apenas o acometimento, mas todos os mistérios que circundam aquele corpo estranho. 
Nessa situação, o olhar do outro não pode ser considerado imparcial visto que ele é impregnado de julgamentos. Segundo Jeudy (2002), o olhar é precedido por um julgamento que baseia-se em razões prévias à maneira de ver. Para tanto, o autor exemplifica tal afirmação:

\begin{abstract}
Uma pessoa que detesto me parecerá feia, mas posso descobrir sob a aparência de sua feiura sinais inacreditáveis de beleza se começo a amá-la. Tudo depende de meus estados de espírito, de meus próprios sentimentos do momento. Essa é a razão por que a ambivalência dos afetos, caso seja determinada pela afirmação soberana de um sentimento e por sua representação corporal, reaparece no "jogo dos olhares. Ela surge no mais íntimo das relações de percepção recíproca, e é o ato de olhar que parece, por sua vez, resolvê-la. (JEUDY, 2002, p.44).
\end{abstract}

Nesse entendimento, o julgamento que precede o olhar baseia-se tanto nos estados de espíritos quanto nos sentimentos do momento que dominam o observador. No entanto, o autor parece atribuir ao olhar o papel principal desta relação. Isso porque Jeudy (ibid.) afirma que apesar da ambivalência dos afetos reaparecer no que ele chama de 'jogo dos olhares', é o ato de olhar que parece resolver as coexistências presentes em tal relação.

A partir dessa abordagem, busca-se contextualizar a ambivalência de sentimentos vividos no conto pela personagem Georgiana, pois, embora o julgamento do outro a tenha afetado de maneira contundente, foi na rejeição do esposo que ela deparou-se com sua maior decepção.

Talvez Georgiana tenha acreditado que o amor de Aylmer seria capaz de fazêlo descobrir em sua marca de nascença "sinais de beleza". De acordo com Jeudy (2002, p.25), o amor leva à variação das representações do belo e do feio, pois ele não deixa de transfigurar o próprio corpo, exacerbando o jogo da atração e da repulsão. Por meio do amor, aquele que parece o mais feio pode tornar-se o mais belo.

Conforme o autor, a ideia de beleza depende tanto das convenções quanto da soberania do sujeito e da arbitrariedade de suas escolhas. O texto descreve a jovem Georgiana dotada de grande beleza; no entanto, a marca em sua bochecha, segundo o olhar do outro, parecia afastar-Ihe da perfeição. Em conformidade com a explanação sobre a ideia de beleza de Jeudy, nota-se que Georgiana foi absorvendo um modo de percepção deturpada de seu corpo, e isso veio a afetar, de maneira decisiva, sua percepção com relação a sua marca de nascença. De acordo com Jeudy (loc.cit.), 
a variabilidade da ideia de beleza bem como os critérios estéticos estão ligados à multiplicidade dos modos de percepção do corpo.

A marca de nascença de Georgiana parecia macular as convenções de beleza da sociedade, pois sua condição de 'imperfeição' a distanciava definitivamente da concepção de beleza ideal. A situação de rejeição do esposo e a falta de aceitação das pessoas reforçavam, ainda mais, a percepção de repulsa que Georgiana passou a nutrir por sua marca. A partir dessa perspectiva, a personagem escolhe retirar, a qualquer custo, sua "imperfeição" do rosto, e, nesse aspecto, voltamo-nos ao que o autor chama de 'arbitrariedade de escolhas' quanto à ideia de beleza. Portanto, podese afirmar, de maneira conclusiva, que não foi a marca de nascença de Georgiana que maculava sua beleza; antes, foi a deturpação da ideia de beleza dos outros que maculou a percepção de beleza da personagem.

\subsection{Macroimpressões do corpo}

O corpo marcado, circundado por experimentações e multiplicidade de percepções 'via pele' ou não, vivencia neste mundo experiências comuns a qualquer outro ser humano. No entanto, esse corpo, de maneira visível ou imperceptível, se diferencia em suas peculiaridades: pele, superfície, textura, relevo, forma, cor e outras características, de um indivíduo que é desprovido de marcas. Por exemplo, as marcas de nascença, desde sua constituição, estabelecem conexões com fatores internos e externos que lhe atribuem um nível de singularidade tão extremada que elas só poderiam ser comparadas com as impressões digitais ${ }^{30}$ presente em cada indivíduo. Para Jeudy (2002, p.83), a pele, invólucro do corpo $^{31}$, aparece como uma superfície com textura singular, as variantes de sua cor, e como um conjunto de fragmentos que se casam bem com as diferentes formas do corpo.

Nesse contexto, pode-se afirmar que a definição da pele como uma superfície com textura singular apresentada por Jeudy (ibid.) reforça a ideia de unicidade atribuída à pele com marcas de nascença que pode, a partir desse entendimento, ser denominada como macroimpressões do corpo. Isso porque, assim como as impres-

\footnotetext{
${ }^{30}$ Marca deixada sobre qualquer superfície por toque com maior ou menor pressão da extremidade de um dedo. Fonte: Dicionário Eletrônico Houaiss da Língua Portuguesa 3.0

${ }^{31}$ Didier Anzieu, 1974, p.207 apud Henri-Pierre JEUDY, 2002, p.83.
} 
sões digitais presentes nas polpas dos dedos de nossas mãos, as marcas de nascença trazem consigo características tão peculiares que não poderiam ser reproduzidas em outro corpo acometido. Essa afirmação parte do entendimento de que a união dos elementos e/ou características de uma certa marca de nascença jamais se constituirá da mesma maneira, a começar pelas infinitas variações presentes nesse processo, tais como: pele, tecido, forma, cor, relevo, peculiaridades do acometimento, dentre outros.

E por que macroimpressões se adequaria a este contexto? Sabe-se que o termo macro ${ }^{32}$ é originado da palavra grega makrós que significa comprido, grande, longo. Assim, o prefixo macro, utilizado na denominação macroimpressão, surge a partir da compreensão de que, em geral, as marcas de nascença podem acometer qualquer local e apresentar-se em qualquer tamanho nos corpos dos indivíduos. Dessa maneira, o termo macroimpressão tem o objetivo de afastar a hipótese de equiparação tanto de local quanto de tamanho com as impressões digitais de nossos dedos, pois sabe-se que a natureza das marcas de nascença não permite nenhum tipo de padronização.

A partir do entendimento de que as macroimpressões do corpo marcado são únicas em cada indivíduo, pode-se afirmar que as trocas com o interno e o externo que aquelas realizam participam dessa mesma natureza. E, apesar de adentrarem o universo da singularidade do indivíduo, essas trocas perpassam mundos conflitantes e, ao mesmo tempo, complementares de sentimentos, fruições e percepções. Essas marcas exploram o mundo do 'Eu' e do 'Outro', do antagonismo de percepções e, ao mesmo tempo, da afinidade de diálogos. No entanto, ao referir-se às trocas entre 0 interno e o externo, a pele não deve ser entendida, simplesmente, como uma superfície intermediária entre o fora e o dentro, visto que, conforme Jeudy (2002, p.84), no dia-a-dia, como num texto, a pele pode ser considerada mais uma superfície de auto inscrição do que uma superfície intermediária.

\footnotetext{
${ }^{32}$ Fonte: Dicionário Eletrônico Houaiss da Língua Portuguesa 3.0.
} 


\subsection{0 corpo exausto}

[..] "One day, very soon after their marriage, Aylmer sat gazing at his wife with a trouble in his countenance that grew stronger until he spoke.

"Georgiana," said he, "has it never occurred to you that the mark upon your cheek might be removed?"

"No, indeed," said she, smiling; but perceiving the seriousness of his manner, she blushed deeply. "To tell you the truth it has been so often called a charm that I was simple enough to imagine it might be so."

"Ah, upon another face, perhaps it might," replied her husband; "but never on yours. No, dearest Georgiana, you came so nearly perfect from the hand of Nature that this slightest possible defect, which we hesitate whether to term a defect or a beauty, shocks me, as being the visible mark of earthly imperfection."

"Shocks you, my husband!" cried Georgiana, deeply hurt; at first reddening with momentary anger, but then bursting into tears. "Then why did you take me from my mother's side? You cannot love what shocks you!". 33

Nesse trecho do conto, o personagem Aylmer revela seu profundo incômodo com relação à marca no rosto de sua esposa. No entanto, a personagem Georgiana demonstra certas reações frente a essa revelação. A partir desse contexto, segue-se rumo a algumas reflexões.

Primeiramente, nota-se que a ambiguidade de reações com que Georgiana recebe a afirmação de seu esposo (sorriso, raiva, choro) parece exteriorizar a natureza conflituosa dos sentimentos que a atormentava interiormente. Essa ideia é reforçada quando Georgiana afirma que ela havia sido ingênua ao acreditar que seu esposo continuaria a associar sua marca a uma espécie de charme.

Denominado paradoxo da expressão de um sentimento, a coexistência da ambivalência de sentimentos explicitada por Jeudy (2002, p.44) aponta que a própria soberania de uma expressão contém o aspecto arbitrário dos opostos que ela une, e

\footnotetext{
${ }^{33}$ HAWTHORNE. 2014, p.1. Tradução do trecho: [..] Um dia, logo depois do casamento, Aylmer sentou e olhando fixamente para sua esposa com uma expressão preocupada em seu semblante que foi gradualmente se intensificando até ele falar. "Georgiana," disse ele, "nunca lhe ocorreu que a marca em sua bochecha pode ser removida?"

"Não, na verdade," disse ela, sorrindo; mas percebendo a seriedade da maneira dele, ficou intensamente corada. "Para dizer a verdade, tenho sido tantas vezes mencionada como referência de charme que fui ingênua o suficiente para imaginar que desta vez seria também."

"Ah, quiçá numa outra face, seria talvez" respondeu o marido; "mas nunca na sua. Não, querida Georgiana. Você veio tão quase perfeita da mão da natureza que o menor defeito possível, no que nós hesitamos a nos referir como um defeito ou uma beleza, me choca; como sendo a marca visível da imperfeição terrena."

"Choca-te, meu marido!" chorou Georgiana, profundamente ferida; primeiramente apresentando uma vermelhidão com raiva momentânea, mas em seguida, irrompendo em lágrimas. "Então por que você me tirou dos braços da minha mãe? Você não pode amar o que te choca!". Tradutora: Juliana Rodrigues.
} 
a certeza que acompanha seu modo de apreensão vem, também, da negação implícita do sentimento contrário.

Imersa nessa ambivalência de sentimentos, Georgiana passa a nutrir uma repulsa tão grande por sua marca que as novas imagens de seu corpo parecem atormentá-la. Para o autor, no texto A tirania do espelho, as imagens do corpo surgem de maneira inesperada e não temos controle sobre elas.

\begin{abstract}
As imagens do corpo ocorrem como alucinações; elas nos atormentam, exacerbando, no momento de sua aparição, a violência do desejo e a angústia da morte. Nós não as produzimos, mesmo que sejamos tentados a construílas; elas surgem quando não as esperamos e nos arrastam na vertigem da epifania do corpo. (JEUDY,2002, p.53).
\end{abstract}

O tormento e a aversão por sua imagem parecem ter impulsionado Georgiana rumo à obstinação pela retirada de sua marca, mesmo que isso viesse a tirar sua própria vida. Dessa maneira, entende-se que, entregue à exaustão por conflitos internos e/ou externos, esse corpo denominado "corpo exausto", entrega-se à morte. Essa entrega parte do princípio de que o "corpo exausto" da personagem se recusava a aceitar a rejeição que vinha sendo submetida, tanto pela sociedade como por seu cônjuge. A partir de então, as imagens do corpo acometido de Georgiana parecem surgir como alucinações, atormentando-a de maneira tão violenta que a aceitação de sua possível morte da matéria torna-se inevitável.

Em O corpo do informe ${ }^{34}$, Pelbart (2003, p.45) aborda questões sobre "O corpo que não aguenta mais". Nesse contexto, o autor afirma que o corpo não aguenta mais tudo aquilo que o coage, por fora e por dentro. Aqui, retomamos a situação limite vivida pela personagem Georgiana, pois, em meio às coações psicológicas externas e às desconstruções de suas percepções internas, a personagem condenase a uma profunda apatia e exaustão que resulta na negação de seu próprio corpo. Segundo o autor:

[..] o corpo não aguenta mais precisamente o adestramento e a disciplina. Com isto, ele também não aguenta mais o sistema de martírio e narcose que o cristianismo primeiro, e a medicina em seguida, elaboraram pra lidar com a dor, um na sequência e no rastro do outro: culpabilização e patologização do sofrimento, insensibilização e negação do corpo. (PELBART, 2003, p.45).

\footnotetext{
${ }^{34}$ PELBART, Peter Pál. O corpo do Informe. In: Vida Capital-Ensaios de biopolítica. Ed. lluminuras Ltda. São Paulo-SP, 2003.p.42-51.
} 
Assim, entende-se que o adestramento e a disciplina que o corpo de Georgiana estaria sendo submetido surge tanto da patologização, o estereótipo da beleza regido pela sociedade, quanto da culpabilização, a privação do direito de singularidade da marca em seu corpo. Para Jeudy (2002, p.179), o estereótipo é considerado, de uma maneira geral, o contrário da singularidade. Destarte, pode-se concluir que, sem o direito à singularidade, "o corpo exausto" de Georgiana rende-se ao sistema de culpabilização e patologização do sofrimento, insensibilização e negação do corpo descrito por Pelbart (ibid.).

\subsection{0 corpo vazio}

Para Pelbart (2003), as barbáries do contexto contemporâneo reduzem as formas-de-vida à vida nua ${ }^{35}$. Conforme a redução biopolítica das formas-de-vida à vida nua, o autor destaca que um dos mais importantes desafios pode ser encontrado na seguinte formulação: "como extrair da vida nua formas-de-vida quando a própria forma se desfez, e como fazê-lo sem reinvocar formas prontas, que são o instrumento da redução à vida nua?". Em seguida, essa reflexão é respondida pelo próprio autor (2003, p.51), na seguinte frase: "Trata-se, em suma, de repensar o corpo do informe, nas suas diversas dimensões". Os personagens analisados por Pelbart ao longo do texto O corpo do Informe, Kafka e Bartleby, cujos corpos eram esquálidos, de gestualidade inerte, passividade originária, tinham seus corpos tornados ativos justamente a partir da passividade constitutiva que, sem negá-la, faziam dela um acontecimento. Mas, se buscamos compreender de uma maneira mais ampla o que é essa vida nua, a partir da análise dos personagens realizada pelo autor, encontramos as pistas:

[...] nesses personagens se expressa uma vida singular, impessoal, neutra, não atribuível a um sujeito e situada para além de bem e mal. Talvez por tratar-se de uma vida que não carece de nada, que goza de si mesma, em sua plena potência-vida absolutamente imanente-que Deleuze referiu-se à beatitude. (PELBART, 2003, p.51).

\footnotetext{
35 "Agambem lembra que os gregos se referiam à vida com duas palavras diferentes. Zoé referia-se à vida como um fato, é o fato da vida, natural, biológica, a "vida nua". Bios designava a vida qualificada, uma forma-de-vida, um modo de vida característico de um indivíduo ou grupo". "Cf.", PELBART, 2003, p.50 e 51. Giorgio Agambem Homo Sacer: o poder soberano e a vida nua I, Henrique Búrigo (trad.). Belo Horizonte, Editora da UFMG, 2002, e Moyens sans fin: notes sur la politique apud Peter Pál Pelbart, 2003, "Vida Nua", p.60-67.
} 
A partir desse entendimento de vida nua, pode-se estabelecer um paralelo com o conto $A$ marca de nascença. Em uma primeira análise, a rendição à morte da personagem Georgiana pode ter sido interpretada como uma fraqueza. No entanto, em uma análise mais minuciosa, percebe-se que a atitude de Georgiana aproximoua das características dos personagens Kafka e Bartleby, descritos por Pelbart (2003). Isso acontece porque o corpo da personagem, aparentemente vazio, obediente, inerte, passivo e rendido à morte, na verdade, teve coragem de escolher entregar-se a morte a ter que viver subjugada à vida nua, sem forma de vida. Afirma-se isso, pois, caso Georgiana vivesse sem a marca de nascença por obediência a formas prontas, não seria exatamente esta vida nua sem forma de vida, referida por Pelbart (op. cit.) que ela estaria subjugando-se?

Assim, entende-se que, a aparente fraqueza do "corpo vazio" de Georgiana rendido à morte, nada mais é do que o corpo que esvaziou-se da vida nua sem formade-vida. E, assim como Pelbart (2003, p.44) atribuiu aos personagens Kafka e Bartleby, talvez Georgiana tenha precisado de sua imobilidade, esvaziamento, palidez, no limite do corpo morto, para dar passagem a outras forças que um corpo "blindado" não permitiria ${ }^{36}$. Nesse contexto, traçando uma analogia com a personagem do conto a partir das afirmativas do autor (2003, p.43), pode-se afirmar que, ao entregar-se à morte, em sua renúncia ao mundo, Georgiana parece ter conseguido o signo de sua resistência.

\subsection{Corpo-Livro}

Contrariando a ideia que perdura como uma tradição filosófica em que a pele substitui a aparência, Jeudy (2002, p.84) afirma que a pele é apenas uma superfície de registro dos sinais da aparência. Por isso, explica que romper a superfície da pele jamais permitiria que se visse o que há por detrás, já que a própria pele é um "existir" que se dá a ler, a ver e a tocar.

A partir dessas afirmativas, pode-se entender que essa superfície de registro dos sinais da aparência chamada pele traz um "existir" carregado de singularidades. Isso pode ser reafirmado quando Jeudy (loc.cit.) apresenta a pele como uma superfície de autoinscrição, como um texto particular, já que é o único a produzir odores,

${ }^{36}$ PESSANHA, Juliano. Certeza do agora. São Paulo, Ateliê. 2002 apud Peter Pál Pelbart, 2003, p.44. 
sons e a incitar o tocar. Por conseguinte, no momento que a pele não é mais percebida como o invólucro das formas, a pele retira do corpo seu status de objeto, um vez que, assim como uma superfície com seus próprios relevos, a pele transforma o corpoobjeto em corpo-texto.

A partir dessas afirmativas, lança-se o seguinte questionamento: a pele com marcas de nascença também pode ser percebida como um corpo-texto? Devido a sua própria natureza, nota-se que a pele com marcas de nascença traz consigo características que uma pele desprovida de tais marcas jamais conseguiria reproduzir. Suas texturas, odores, cores, dentre tantas outras características únicas, parecem fundir-se com a pele, criando uma superfície de autoinscrição singular bem como um texto particular que também não se submete às regras de sentido.

De modo comparativo, pode-se afirmar que apesar da pele com marca de nascença trazer consigo as características pelas quais ela pode ser percebida como um corpo-texto, sua natureza parece requerer um termo mais adequado a sua complexidade compositiva. Segundo tal conjectura, pode-se refletir: o termo mais adequado para a pele com marcas de nascença é corpo-livro?

Em busca de uma reflexão mais profunda a respeito do livro, voltemo-nos à análise realizada por Maurice Blanchot (2013) no O livro por vir. Nele, Blanchot apresenta as concepções de Mallarmé37 de uma grande obra: um livro único composto de vários volumes que "[..] desde o começo já é o livro, o essencial da literatura, é também um livro, "simplesmente [...]” (Blanchot, 2013, p. 327).

Um traço invariável desse livro é que ele seria "arquitetural e premeditado, e não uma compilação de inspirações do acaso, mesmo que maravilhosas" (op. cit., p.328). Para Blanchot, ao referir-se ao plano da obra como uma tarefa acabada, Mallarmé (ibid.) parece meditar sobre a estrutura do livro como se este já existisse em seu espírito antes mesmo do conteúdo.

\footnotetext{
37 "A partir de 1866, Mallarmé sempre pensou e disse a mesma coisa sobre o significado da palavra livro. Entretanto, o mesmo não é sempre o mesmo. Uma das tarefas seria a de mostrar por que e como essa repetição constitui o movimento que lhe abre, lentamente, um caminho". "Cf.", BLANCHOT, 2013, p.327. Talvez, a partir dessa reflexão de Blanchot, pode-se apontar o percurso de análise do desenvolvimento e período da obra de Mallarmé realizada pelo autor. Quanto aos documentos de consulta, Blanchot refere-se ao manuscrito que Henri Mondor entregou a Jacques Scherer que foi cuidadosamente organizado por este e publicado sob o título: Le "Livre" de Mallarmé- premières recherches sur des documents inédits". [O "Livro" de Mallarmé - primeiras pesquisas sobre documentos inéditos]. Projetos de Mallarmé editadas por Jacques Scherer (BLANCHOT, 2013, p.337).
} 
Em uma referência ao que parece ser um prenúncio do futuro, Mallarmé38 acredita que, caso ele escreva algo fora da obra, esse será um "soneto nulo". Isso porque, ao proceder dessa maneira, "parece havê-lo destinado a não escrever mais do que poemas nulos, isto é, a dar força e existência poética somente àquilo que existe fora de tudo (e fora do livro que é esse tudo), mas, assim fazendo, a descobrir o próprio centro do Livro". Blanchot, 2013, p.329.

Enveredando rumo à complexidade deste livro, o autor afirma:

O livro que é o Livro é um livro entre outros. É um livro numeroso, que parece se multiplicar por ele mesmo, por um movimento que lhe é próprio e no qual a diversidade do espaço em que se desenvolve, segundo diferentes profundidades, realiza-se necessariamente. (BLANCHOT, 2013, p.331).

Nesse trecho, nota-se que o autor faz menção a um livro que parece abrigar a multiplicidade como uma característica que lhe é própria, e na qual a diversidade do espaço e profundidade do seu desenvolvimento Ihe possibilitam o realizar-se. Em complemento a essa afirmação, Blanchot (2013, p. 331) diz que o livro necessário é subtraído ao acaso. No entanto, essa casualidade ganha o escape por meio de sua estrutura e delimitação que, ao realizar a essência da linguagem, desgasta as coisas e as transforma em sua ausência que abre-se ao devir rítmico; o movimento das puras relações. Conforme o autor (loc. cit.), essa ideia nos remete a uma das mais célebres afirmações de Mallarmé (ibid.) em que "o livro sem acaso é um livro sem autor: impessoal”. (id.). Dentre os vários estudos que essa frase possibilita, nos deteremos no ponto em que Blanchot (op. cit.) destaca a frase de Mallarmé (ibid.) como uma possível resposta a esse referido anonimato: "Acredito que tudo isso está escrito na natureza, de modo que só se deixe de olhos fechados os interessados a nada ver [..]" ${ }^{39}$

Em uma breve síntese do que viria a ser o utópico livro de Mallarmé (ibid.), no livro por vir, Blanchot (2013, p.359) afirma que "O livro é assim, discretamente, afirmado no devir que é talvez seu sentido [..]. O fim da obra é sua origem, seu novo e seu antigo começo: é sua possibilidade aberta uma vez mais [..]".

Após um maior aprofundamento nas reflexões acerca do livro realizada por Blanchot, a partir da obra de Mallarmé (ibid.), entende-se que a pele com marcas de nascença parece ter encontrado, tanto neste estudo quanto nas percepções de

\footnotetext{
${ }^{38}$ Stéphane Mallarmé apud Maurice Blanchot, 2013, p.329.

${ }^{39}$ Id., 2013, p. 332.
} 
Jeudy (2002), a complexidade de concepções que fundamentam sua designação poética de corpo-livro. Esse entendimento acontece da seguinte maneira: primeiramente a proposição desse termo abriga a ideia de Jeudy (ibid.) de um corpo que possui uma pele que é um "existir" que se dá a ler, a ver e a tocar, e que é, também, uma superfície de autoinscrição que produz textos particulares. Essa concepção, por sua vez, estende-se à pele com marcas de nascença visto que ela torna-se um "existir" singular que é capaz de produzir "textos" ainda mais complexos. Em um segundo momento, pode-se afirmar que o livro de Mallarmé (ibid.) descrito por Blanchot (2013) - um livro que parece carregar a multiplicidade em si mesmo visto que ele se desenvolve em seus vários níveis de profundidade - acolhe a concepção de livro cujo "conteúdo" transcende a produção de textos. Dessa maneira, o corpo-livro encontra sua construção poética na qual o corpo com marcas de nascença envereda-se rumo a uma "escrita da natureza", sendo que o centro do livro parece ser um contínuo constituir-se cuja definição trazida por Blanchot (2013, p.259) sintetiza sua complexidade: [..]. 0 fim da obra é sua origem, seu novo e seu antigo começo: é sua possibilidade aberta uma vez mais [..]".

Quanto à recepção desse corpo-livro, é importante destacar que, mesmo que o receptor receba as marcas de nascença, não é possível definir quais associações que esse receptor estabelecerá com o seu repertório individual a fim de realizar a "leitura" de tais (re)significações. Assim, por um lado, pode-se afirmar que o único aspecto previsível desse "processo de comunicação" refere-se ao "conteúdo inédito" dos corpos com marcas de nascença. Por outro lado, pode-se asseverar que é justamente a imprevisibilidade do "elemento surpresa" trazido pelas interpretações do receptor que colabora com a proposição deste corpo-livro de ser um contínuo "devir". 


\section{CAPÍTULO 2}

\section{HEMANGIOMA, ARTE E FOTOGRAFIA}

Sabe-se que o corpo humano tem sido um dos mais significativos temas de pesquisa científica, e que, atrelado às novas tecnologias, os recursos de investigação têm se tornado cada vez mais avançados. Sendo assim, pode-se afirmar que o atual vasto conhecimento científico sobre as marcas de nascença, bem como suas reais causas, diagnósticos, classificações e tratamentos têm favorecido tanto os estudos médicos quanto a qualidade de vida das pessoas. Embora muitos acreditem que a ciência médica deva restringir-se ao seu campo de atuação, nota-se que muitas temáticas podem ser reflexionadas em outras áreas de conhecimento.

Com o intuito de corporificar ainda mais essas reflexões, o conto 'A marca de nascença' continua a atuar como paradigma poético, contribuindo, assim, de maneira significativa às construções deste capítulo. Nesse contexto, nota-se que a obstinação de Aylmer na retirada da marca de nascença que trazia imperfeição à Georgiana se baseia em sua total credibilidade na ciência. A partir dessa perspectiva reflexiva, dáse início às discussões do segundo capítulo sobre Hemangioma, Arte e Fotografia no qual pretende-se aprofundar o estudo teórico das concepções artísticas e fotográficas que dialoguem com a marca de nascença denominada hemangioma. Uma vez que, acredita-se que a abordagem científica do hemangioma, aliada às experimentações artísticas e tecnológicas, podem favorecer a construção de um novo olhar rumo ao corpo com marcas de nascença.

Dentre as inúmeras marcas de nascença existentes, a escolha pela abordagem específica do hemangioma deve-se ao fato de que o corpo gerador das construções artísticas deste trabalho é acometido com hemangiomas e possui uma trajetória de imersão artística do tema já descrita nesta dissertação.

\subsection{A marca de nascença e a ciência a partir do conto}

"[..] Georgiana, you have led me deeper than ever into the heart of science. I feel myself fully competent to render this dear cheek as faultless as its fellow; and then, most beloved, what will be my triumph, when I shall have corrected what Nature left imperfect, in her fairest work! [..]"40.

\footnotetext{
40 HAWTHORNE, 2014, p.3. Tradução do trecho: [..] Georgiana, você me conduziu mais profundo do que nunca a adentrar o coração da ciência. Sinto-me plenamente competente para tornar esta querida bochecha tão perfeita como a outra; e depois, mais amada, o que será o meu triunfo, quando eu tiver corrigido o que a natureza deixou imperfeito, em sua obra mais bela! [..]. Tradutora: Juliana Rodrigues.
} 
Nesse trecho do conto A marca de nascença, o homem da ciência chamado Aylmer afirma sentir-se plenamente competente para tornar a bochecha de Georgiana perfeita. Dessa maneira, o personagem se propunha a corrigir a imperfeição que a natureza havia deixado, segundo ele, em sua obra mais bela. A partir desse entendimento, surge o seguinte questionamento: a busca pela perfeição e a verdade absoluta da ciência contrapôs-se à imperfeição no corpo de Georgiana?

Nesse contexto, a afirmação de Agambem ${ }^{41}$ parece abarcar a perspectiva de verdade absoluta da ciência. Conforme o autor, a literatura e o pensamento também fazem experimentos tal qual a ciência. Mas enquanto a ciência visa provar a verdade ou falsidade de uma hipótese, a literatura e o pensamento têm outro objetivo, pois eles são experimentos sem verdade. Em complemento a essa afirmativa, o autor acrescenta que, embora a literatura e o pensamento apresentem seus experimentos sem objetivar verdades, ambos exercem um papel de suma importância ao contrapor-se às verdades científicas.

Voltando-se para um outro aspecto trabalhado no referido conto, observa-se que, apesar do personagem Aylmer ser apresentado como um homem voltado para a ciência, a descrição de seus experimentos científicos enfatiza o seu interesse pelos estudos em diversas áreas de conhecimento, inclusive a alquimia. A grande diversidade de temas dos livros encontrados por sua esposa Georgiana no laboratório de Aylmer parece confirmar tal conjectura. Assim, ao descrever um homem da ciência voltado para pesquisas de diferentes naturezas, o autor parece propor uma possível aproximação entre linguagens.

\subsubsection{Arte e Ciência}

De maneira geral, a ciência parece ser entendida em contraposição a outras áreas de conhecimento. No entanto, sob a égide de uma nova perspectiva no livro $A$ pesquisa em Arte, Silvio Zamboni (2006) estabelece um importante paralelo entre Arte e Ciência. Para o autor, a atividade do pensamento permeia todo e qualquer tipo de conhecimento humano, e é, nesse sentido, que se pode falar em ambos, a questão

${ }^{41}$ Giorgio Agamben, 1995, p.59 Apud Peter Pál Pelbart, 2003, p.42. 
do racional e da intuição em relação à arte e à ciência, como pertencentes ao conhecimento humano como um todo.

De acordo com Zamboni (2006), a ciência é comumente entendida como um veículo de transmissão de conhecimento em detrimento da não habitualidade de aplicação da mesma função à Arte. Portanto, faz-se necessário entender que a arte não é apenas conhecimento em si mesma, visto que ela também pode vir a ser um importante veículo para outros tipos de conhecimento humano.

Dessa maneira, Zamboni (id.) afirma que a arte não contradiz a ciência; ela apenas utiliza-se de meios que nos leva a compreensão de certos aspectos de maneira que a ciência não se permite fazer. Assim, entende-se que o que existe são formas de pensamentos que, habitualmente, se relacionam ao tipo de atividade utilizada em arte e outras com as atividades de ciência. Uma das diferenças que pode ser pontuada entre essas formas se deve ao fato de que a explicação na ciência volta-se para um caráter geral. Ou seja, a ciência busca leis que sirvam para generalizações, e poderão ser aplicadas em outras realidades. Já a explicação artística é extremamente particular, embora sua transmissão de mensagens seja bastante ampla.

Segundo as concepções de Zamboni (id.), a criação artística espelha a visão pessoal do artista da mesma forma que a criação científica reflete a visão pessoal do cientista. Isso porque, segundo o autor, a diferença entre uma obra e outra não está no ato criativo, mas no processo de trabalho fundamentado num determinado paradigma e no conhecimento acumulado de quem realiza a obra.

Aplicando esse entendimento ao personagem Aylmer, entende-se que, caso ele fosse homem das artes, o ato criativo de sua obra no campo artístico não se oporia ao da ciência. Entretanto, seus processos aconteceriam de maneira distinta, mas nem por isto destituídos de criatividade. Ainda segundo o autor (2006), o ato criativo excede o universo da arte e que, portanto, a restrição da criatividade às atividades intelectuais constitui-se um erro tendo em vista que o cientista necessita da criatividade tanto quanto $o$ artista. 


\subsection{Abordagem médica da marca de nascença hemangioma}

Com o intuito de dar prosseguimento às discussões propostas neste capítulo, antes de dialogar com as possibilidades artísticas e fotográficas, a marca de nascença hemangioma será apresentada no âmbito do conhecimento científico médico.

\subsubsection{Marcas de nascença}

O termo médico utilizado para descrever as lesões na pele popularmente conhecidas como mancha, pinta ou sinal é denominado nevo. O termo nevo é derivado do latim nævus ${ }^{42}$ e significa mancha, nódoa no corpo, sinal, verruga. Para Yamada e Yarak $(2006)^{43}$, nevo é sinônimo de uma malformação circunscrita, de origem embriopática (falha na embriogênese) ou hereditária, neoplásica ou não neoplásica. O nevo também é definido como uma neoplasia benigna constituída de células névicas (nevos melanocíticos) ou como lesão presente ao nascimento composta pelo excesso de estruturas maduras ou quase maduras - hamartoma ${ }^{44}$. Em dermatologia, o termo nevo ${ }^{45}$ significa marca de nascença hiperpigmentada, excesso de pigmentação, ou vascularizada e utiliza-se tanto para designar manchas congênitas ${ }^{46}$ quanto para manchas adquiridas após o nascimento.

A maior parte das marcas de nascença é proveniente de desordens no sistema vascular ou pigmentar do indivíduo. Focalizando a primeira classe de desordens, à qual o hemangioma pertence, entende-se que as desordens vasculares se referem a anomalias que acometem o sistema vascular. Dependendo da variação da concentração dos vasos sanguíneos sob a superfície da pele, a marca sofrerá uma variação em sua coloração e aparência. Por exemplo, as manchas de coloração rosa são mais discretas e popularmente conhecidas como "beijos de anjos" ou "mordidas de cegonha". Já as manchas vermelhas são mais aparentes e são chamadas em alguns países de "morango". 47

\footnotetext{
${ }^{42}$ Fonte: Dicionário Eletrônico Houaiss da Língua Portuguesa 3.0.

43 YAMADA, Sérgio e YARAK, Samira. Nevos In LOPES, Antônio Carlos (Editor). Diagnóstico e tratamento, volume 2, 2006, p.517.

${ }^{44}$ Malformação congênita de aspecto tumoral, caracterizada por misturas anormais de tecidos próprios do órgão em que se apresenta. Fonte: Dicionário Eletrônico Houaiss da Língua Portuguesa 3.0.

${ }^{45}$ Fonte: Dicionário Eletrônico Houaiss da Língua Portuguesa 3.0.

${ }^{46}$ Característico do indivíduo desde o ou antes do nascimento; conato. Fonte: (id.).

${ }^{47}$ Disponível em: <http://www.jornalciencia.com/saude/beleza/2324-os-mitos-e-os-misticismosbizarros-por-tras-das marcas-de-nascenca>. Acesso em: 07 mar. 2013. 22:35:50.
} 


\subsubsection{Hemangioma}

Nesta subseção, tratarei acerca do hemangioma, destacando, em um primeiro momento, sua classificação em relação às várias anomalias existentes, para depois abordar seu histórico, e, por fim, apresentar uma definição para esse termo.

\subsubsection{Classificação}

A marca de nascença chamada hemangioma pertence ao grupo das Anomalias Vasculares Congênitas. Segundo Tau e Martins (2006) ${ }^{48}$, as anomalias vasculares congênitas periféricas abrangem todas as anormalidades das estruturas vasculares nascidas com o indivíduo (malformações, disrupções, deformações, displasias, persistência de estruturas embrionárias e síndromes), com exceção das variações anatômicas.

\subsubsection{Histórico}

O termo hemangioma foi introduzido por Fraser no ano de 1919. E apesar da existência de outras denominações na época, pode-se afirmar que, por um longo período, o termo hemangioma foi comumente utilizado para denominar grande parte dos acometimentos de natureza vascular. Provavelmente, a justificativa para o uso indiscriminado do termo decorra do fato de que a classificação das anomalias vasculares era dificultada pela semelhança entre as lesões, os vários aspectos ainda desconhecidos pela ciência e pela história clínica diferenciada em cada indivíduo.

Com o objetivo de universalizar a nomenclatura e facilitar a troca de informações científicas, a Sociedade Internacional para o Estudo das Anomalias Vasculares-ISSVA, fundada em 1992, adota a classificação de Mulliken \& Glowacki (1982). As manifestações são diferenciadas com base em suas características celulares, aparência clínica e história natural. Assim, baseando-se na análise das características celulares, por meio de biópsias, as anomalias vasculares foram classificadas em dois grupos: os Hemangiomas e as Malformações Vasculares. ${ }^{49}$

\footnotetext{
48 TAU, Ana Paula Bagdadi e MARTINS, Dulce Maria F. Soares. Classificação das anomalias vasculares congênitas In LOPES, Antônio Carlos (Editor). Diagnóstico e tratamento, volume 2, 2006, p.13. ${ }^{49}$ As malformações vasculares são consequência de erros na formação ou morfogênese ou no desenvolvimento do sistema vascular embrionário e fetal. Podem ser classificadas de acordo com o vaso predominante. Fonte: Diagnóstico e tratamento, volume 2, 2006, p.14.
} 
Em 1996, a necessidade de classificação para tumores raros, que também surgem na infância, resultou na revisão da antiga classificação. Após a realização dos ajustes, a nova classificação foi oficialmente aceita pela Sociedade Internacional para o Estudo das Anomalias Vasculares-ISSVA. Assim, temos a classificação das anomalias vasculares em tumores (hemangioma e outros tumores raros) e malformações vasculares (capilar, venosa, linfática, arterial e combinada). Entretanto, essa divisão não pode ser afirmada como absoluta, pois a coexistência de tumores e malformações não pode ser totalmente descartada. No entanto, é possível afirmar que os estudos e a classificação resultante deste processo representam um avanço significativo para a abordagem das anomalias vasculares no âmbito científico.

\subsubsection{Definição}

O hemangioma pode ser definido como uma neoplasia ${ }^{50}$ vascular benigna ou tumor vascular benigno de células endoteliais e de involução espontânea. Também pode ser entendido como um acúmulo anormal de vasos sanguíneos que acomete a pele ou os órgãos internos. Essas lesões podem desenvolver-se em diversas regiões do corpo, comprometendo, geralmente, os sistemas venoso, arterial ou linfático do indivíduo.

Trata-se de lesões bastante comuns na infância que manifestam-se com frequência em crianças brancas e do sexo feminino. A relação de frequência entre muIheres e homens é de 5:1. Grande parte dos acometimentos surge algumas semanas após o nascimento e, em geral, o aspecto da mancha é pequena e avermelhada. $\mathrm{Na}$ maioria dos casos caracteriza-se por uma fase de crescimento rápido, chamada proliferativa, que acontece nos primeiros meses de vida e, por vezes, de maneira desproporcional ao crescimento da criança.

Segundo Tau e Martins (2006) ${ }^{51}$, macroscopicamente, a maioria das lesões apresenta-se proeminente e de coloração vermelha rutilante (strawberry). Em se-

\footnotetext{
50 Processo patológico que resulta no desenvolvimento de um neoplasma (crescimento anormal, incontrolado e progressivo de tecido, mediante proliferação celular; tumor); neoformação (formação de tecido novo que restaura ou substitui o tecido lesado por feridas ou traumatismos). Fonte: Dicionário Eletrônico Houaiss da Língua Portuguesa 3.0.

${ }^{51}$ TAU, Ana Paula Bagdadi e MARTINS, Dulce Maria F. Soares. Classificação das anomalias vasculares congênitas In LOPES, Antônio Carlos (Editor). Diagnóstico e tratamento, volume 2, 2006, p.13.
} 
guida, acontece a fase da regressão lenta, parcial ou completa da lesão. Em sua maioria, quando ocorre a fase da lenta regressão, ela se completa até os sete anos de idade e nunca ultrapassa a fase de adolescência do indivíduo. A diminuição da lesão acontece na vagarosa fase chamada de involução centrífuga. ${ }^{52}$

De acordo com as autoras citadas, grande parte das lesões dessa natureza se apresenta de maneira superficial e pequena o que, geralmente, não acarreta transtornos funcionais ou estéticos ao indivíduo. No entanto, cerca de $10 \%$ dos casos sofrem complicações e necessitam de tratamento específico. Um fator determinante, nesse contexto, refere-se tanto à localização dos hemangiomas quanto ao grau de comprometimento das lesões no corpo do indivíduo, pois, dependendo dessa combinação de fatores do acometimento, há probabilidade de compressão de órgãos, favorecimento de infecções, deformidades e pode até causar sérios danos à saúde.

\subsection{Abordagens artísticas: construção de diálogos}

Nota-se que a abordagem da marca de nascença, hemangioma, no âmbito da ciência médica, apresenta um objeto de estudo analisado por um prisma puramente científico. Isso ocorre porque, independentemente das variáveis presentes na investigação, seu objetivo parece voltar-se para uma real tentativa de aperfeiçoar o que a natureza parece ter deixado "imperfeito".

Com o propósito de ampliar esta discussão, retoma-se a abordagem do conto ${ }^{53}$ que traz o uso da ciência com o propósito de corrigir a imperfeição que a natureza havia deixado no corpo da personagem Georgiana. A partir dessa ideia, pode-se afirmar que apenas a ciência objetiva aperfeiçoar a natureza a todo custo? E quanto à Arte, estaria ela isenta da busca por uma representação ideal da natureza?

$\mathrm{Na}$ tentativa de elucidar tal questionamento, a afirmação dos autores Ortega Y Gasset (1999) pode auxiliar na reflexão desse assunto. Segundo esses autores, durante o século XIX, os artistas procederam demasiadamente impuros, visto que reduziam, ao mínimo, os elementos estritamente estéticos, e faziam a obra consistir,

\footnotetext{
52 (Id.) Segundo as autoras (2006, p.13-14) nesta fase acontece a diminuição da celuraridade, fibrose e infiltração gordurosa. Em decorrência disto, ocorre a diminuição da lesão que torna-se esbranquiçada até sua total substituição por tecido cicatricial. Após este processo podem surgir sequelas dérmicas. ${ }^{53}$ HAWTHORNE, 2014, p.3. A ideia a que se refere o texto pode ser encontrada no diálogo entre Georgiana e o personagem Aylmer onde ele declara que seu maior triunfo seria quando ele, enquanto homem conhecedor da ciência, conseguisse corrigir a imperfeição que a natureza havia deixado na bochecha de sua esposa.
} 
quase inteiramente, na ficção de realidades humanas. Nesse sentido, acrescentam que, em um ou outro aspecto, toda a arte normal da centúria passada foi realista.

Apesar de não ter a intenção de aprofundar as discussões que podem surgir a partir da afirmação acima descrita, sabe-se que, de uma maneira geral, o paradigma Modernista rompeu com os antigos modelos que regiam o cenário artístico no início do século XX. Sendo assim, a partir do paradigma Modernista, bem como das novas abordagens assumidas pela Arte no início do século XX, surgem os estudos das posturas artísticas que dialogam com as construções artísticas desenvolvidas no próximo subcapítulo.

\subsubsection{O corpo e a recepção a partir da Arte Moderna}

A abordagem proposta neste tópico buscou enfatizar as reformulações que a Arte Moderna trouxe à recepção da obra de arte devido ao importante papel que o receptor exerce nas produções artísticas desta pesquisa.

No livro A estratégia dos signos, Lucrécia Ferrara (2005) aponta que, dentre suas importantes transformações, o fator de grande revolução da Arte Moderna não estava focado na produção, mas na recepção da obra. Isso porque ao desconstruir o papel do espectador passivo, entende-se que a antiestética modernista validou a participação de um receptor ativo. Dessa maneira, o receptor afasta-se de sua condição passiva e passa a assumir um papel de suma importância tanto na recepção quanto na atuação das ações que integram a obra. Nessa nova proposta, o receptor ativo não dialoga e interage apenas com a obra, mas com o universo. De acordo com a autora:

\footnotetext{
A Arte Moderna é a produtora de um receptor hábil onde tudo solicita a sua percepção e está aberto à sua penetração, sua interferência é a única possibilidade de produção de sentido; sentido fugaz, relativo, mas válido porque produto de uma inteligência, de uma sensibilidade, de uma atividade relacional. (FERRARA, 2005, p.20).
}

Com relação à abordagem da recepção, Ferrara (2005) traz o conceito de "estranhamento" criado por Chklóvski em 1916, cuja especificidade da obra de arte acontece pelo desenvolvimento de procedimentos que levam o receptor a ver a realidade de outro modo, o que implica um re-conhecimento, isto é, não identificar, porém, conhecer outra vez. 
Para Ferrara, a teoria de Chklóvski (1916) que se apoia na ação de estranhar o objeto representado procura transpor o universo para uma esfera de novas percepções que se opõe ao peso da rotina, do hábito, do já visto, pois, ao extrair o objeto do seu contexto habitual, o artista destrói os clichês, impondo-lhe uma complexa percepção sensorial do universo.

Nesse contexto, pode-se afirmar que as produções artísticas, a partir do tema hemangioma, vêm ao encontro dos princípios da teoria de estranhamento de Chklóvski (ibid.). Isso se deve ao fato de que, por meio da ação de estranhamento que o hemangioma provoca, as produções artísticas buscam despertar novas percepções no receptor de maneira que este possa perceber a realidade de uma outra maneira, desvinculando, assim, o peso da rotina médica do objeto.

Rosalind Krauss (2007) aborda sobre a ampliação das relações espaciais nas obras a partir das novas posturas assumidas pela arte. O lugar-inclusão parece atrelar-se ao contexto espacial no sentido da obra. Segundo a autora (ibid.), trabalhos, por exemplo, como os do artista Robert Morris, apontam para as potencialidades de abertura das relações do objeto em relação ao contexto espacial. De maneira geral, a sensibilidade em relação ao contexto espaço de exposição cresceu a partir dos minimalistas dos anos 60. Artistas como Yves Klein (1928-1962) e Richard Serra (1939-) ampliaram a relação entre o elemento construído e o lugar. Redefiniram o espaço por meio de situações geradas entre a ação artística e as referências locais.

A obra Labirinto (1974), figura 12, do artista Robert Morris (1931-) trabalha as questões espaciais por meio da ideia de passagem, que, segundo Krauss (2007), é uma obsessão da escultura moderna. Assim, a transformação da escultura, que teve início com Rodin, atinge sua plenitude ao possibilitar a passagem de um veículo estático e idealizado num veículo temporal e material.

Para Krauss (2007), a imagem da passagem trabalhada na obra de Robert Morris e outros artistas, tais como Corredor (1968-70) por Bruce Nauman (1941-); Desvio (1970-72) por Richard Serra (1939-); e Quebra-mar espiral (1969-70) de Robert Smithson (1938-1973), serve para colocar tanto o observador como o artista diante do trabalho e do mundo, em uma atitude de humildade fundamental a fim de encontrarem a profunda reciprocidade entre cada um deles e a obra. 


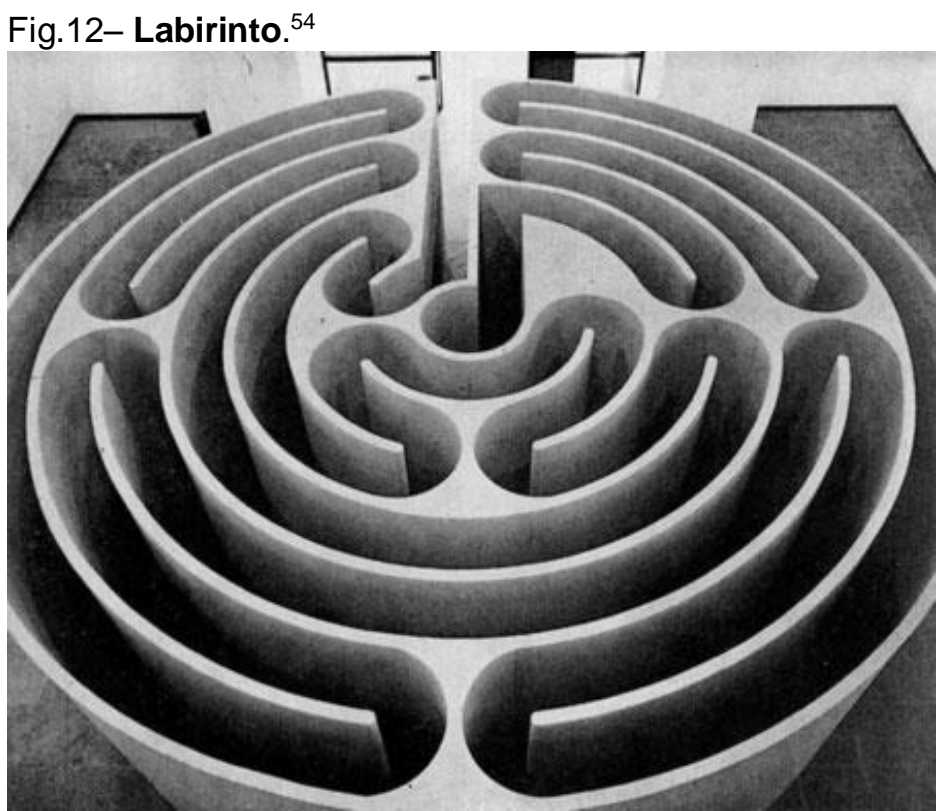

Fonte: Robert Morris, 1974.

No livro A poética do espaço de Gastón Bachelard (2003), as relações do homem com o espaço são abordadas sobre a égide da dimensão poética. Ao apresentar a casa como centro da vida do ser humano o autor estabelece uma dialética entre o exterior e o interior.

De acordo com Bachelard (2003), a casa é o lugar de onde o homem parte e para onde ele sempre retorna, estabelecendo, neste ínterim, diferentes relações com o mundo. Para o autor, todo lugar realmente habitado traz a essência da noção de casa, e, para que o homem se entregue aos seus pensamentos, às suas memórias, ele precisa habitar.

Quanto ao corpo, pode-se afirmar que a realização das ações extremistas não objetivam apenas chocar. O seu propósito consistia em estabelecer uma comunicação com o receptor, banindo sua indiferença e reconduzindo-o à reflexão e à ação perante determinados fatos da realidade, tais quais política, preconceito, sexualidade, ecologia, dentre outros.

Para Pires (2005), a relação da obra de arte que mais choca o receptor é a arte que utiliza o corpo como suporte porque o caráter sagrado continua atrelado ao corpo. Sendo assim, nossa cultura, há séculos, determina que o corpo seja preservado da exposição pública, pois ele é o reduto da intimidade e da dor.

${ }^{54}$ Disponível em:<http://www.architetturadipietra.it/wp/?p=1977>. Acesso em: 23 abril 2014. 20:38:27. 
Contextualizando a abordagem de comunicação com o receptor, nota-se que os trabalhos de Lygia Clark (1920-1988), principalmente nos anos 60-70, propunhamse a converter a passividade do receptor em reflexões, ações e interações com o interno, o externo, o outro, dentre outros segmentos e possibilidades. Nesse contexto, a ação do corpo dos artistas e do corpo do próprio receptor faz parte, revela e é instigado a executar a própria obra.

No trabalho de Lygia Clark (1968-1970) intitulado "O corpo é a casa", figura 13, a artista instiga ações coletivas do receptor. Trata-se de uma proposta de experiência grupal que distancia-se cada vez mais do objeto, visto que o corpo do outro passa a ser o suporte das experimentações grupais. Ao inverter o título da instalação "A Casa é o corpo", Clark enfatiza a inversão de papéis atribuídos ao corpo. O corpo então passa a ser o meio das ações vivenciadas pelo coletivo, e essas ações gestuais parecem construir o corpo enquanto abrigo para o outro. No texto Da supressão do objeto -anotações - Clark (1975), In: Escritos de Artistas (2006), descreve suas proposições de ações coletivas da seguinte maneira:

[..] Já nada invento só: as invenções nascem a dois, a três numa troca comum de diálogo, sendo isso que mais colado à vida consegui propor. Divido a proposição e aceito a invenção do outro. Grande instinto de morte colado à grande vitalidade. [..] O silêncio, a interação do coletivo, a recompensa do meu eu, a procura de um profundo sentido de vida no grande sentido social, o meu lugar no mundo. [..] (CLARK. In: Escritos de Artistas, 2006, p.355).

Fig.13- "A Casa é o Corpo: Labirinto". 55

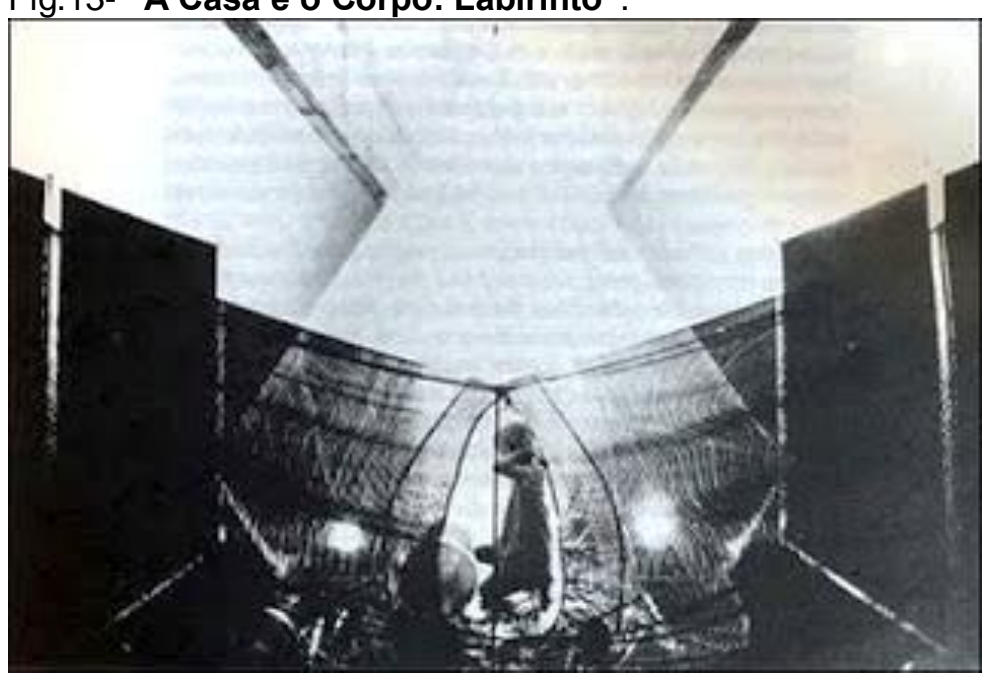

Obra: Lygia Clark, 1968.

55 Instalação realizada no ano de 1968 no MAM-RJ e na Bienal de Veneza.

Disponível em: <http://multissenso.blogspot.com.br/2009/11/lygia-clark-casa-e-o-corpo-labirinto.html> Acesso em: 22 abril 2014. 22:40:57. 
A relação pontuada por Plaza (2003) entre autor-obra-recepção também pode contribuir no sentido de uma maior compreensão do novo papel do receptor na contemporaneidade. Segundo Plaza (ibid.), ${ }^{56}$ a interação entre obra e público sempre aconteceu e em diferentes graus de abertura, seja por meio do conceito de obra aberta, de obra participativa ou interativa.

O conceito de obra aberta, definido como "a abertura de primeiro grau", permitiu ao observador a interpretação, a multiplicidade de leituras e a riqueza de sentidos. O observador tem uma maior aproximação e intimidade para expressar sua leitura sobre a obra.

A obra participativa, cujo conceito diz respeito à "abertura de segundo grau", é uma "arte de participação", como o próprio nome denomina, que objetiva "encurtar a distância entre criador e espectador", (Plaza, 2003). A participação ativa, lúdica e criativa do espectador permite que ele manipule e/ou explore tanto o objeto artístico quanto o seu espaço.

A arte interatividade, definida em termos da "abertura de terceiro grau", propõe obras inovadoras e "abertas", em que a percepção, as dimensões temporais e espaciais representam um papel decisivo na relação homem-máquina. Para Plaza (ibid.), a intervenção da máquina atua como novo e decisivo agente de instauração estética. A participação do espectador se dá por meio da interatividade, da relação recíproca entre usuários e interfaces, da criação partilhada e em redes.

Esta breve síntese que apresenta as postulações de autores, assim como as concepções e obras de alguns artistas que se propuseram a incorporar as importantes mudanças ocorridas no processo de recepção, trazem reflexões que se identificam com a proposta de recepção das produções artísticas desta pesquisa. Nesse sentido, destaca-se principalmente a abertura de comunicação pontuada por Plaza (ibid.) entre autor-obra-recepção que acontece a partir do novo papel do receptor na contemporaneidade.

Sendo assim, entende-se que as construções fotográficas, geradas a partir da projeção do hemangioma no corpo do outro, busca trabalhar uma comunicação com o receptor na qual ele possa encontrar esse "lugar-inclusão", e venha a construir um

${ }^{56}$ Disponível em: <http://www.iar.unicamp.br/disciplinas/ap858/AXILA/pagjulioplaza.html> Acesso em: 27 maio 2012.19:17:05. 
olhar reflexivo frente às novas perspectivas da obra, afastando, ainda, a tradicional visão do corpo como um reduto apenas da intimidade e da dor.

\subsubsection{O corpo e as obras de arte}

Sabe-se que a antiestética modernista que se contrapôs aos padrões estéticos estabelecidos na Arte Clássica e que libertou o objeto de arte do seu uso convencional enveredou por caminhos repletos de novos códigos, ferramentas e ressignificados tanto para o artista, o receptor, assim como, para todo o cenário artístico.

Em um breve panorama com relação a essa afirmação, nota-se que as novas posturas assumidas pela Arte a partir das formatações transgressoras dos movimentos das décadas de 60 e 70, bem como suas projeções em outras vertentes, fomentaram a proposição de novos suportes tanto para Arte quanto para o corpo enquanto Arte.

Dentro dessa perspectiva, afirma-se que, associado às perfomances, happenings, a body art, body modification, modern primitives, bem como outros movimentos artísticos, novas concepções foram sendo incorporadas pelos artistas que, por vontade própria, realizavam os mais diferentes tipos e níveis de interferência em seus corpos e no corpo do outro. Logo, a partir das conceituações abordadas por tais processos do fazer artístico, os corpos foram submetidos a uma grande diversidade de técnicas e intervenções, tais como suspensão, mutilações, sacrifícios, rituais, amarrações, implantes e cirurgias plásticas, perfurações, tatuagens, escarificações, cortes, feridas, piercings, dentre tantos outros.

A partir desse contexto, pode-se afirmar que, além dos novos diálogos estabelecidos entre o receptor e o corpo enquanto obra de arte, um novo fazer artístico foi construído a partir do tema corpo. Dessa maneira, o corpo estabelece novos diálogos com o universo artístico, assumindo importantes papéis diante das novas ações que resultaram no corpo, como o próprio suporte para essas experimentações e investigações tanto artísticas quanto em diversas áreas do conhecimento.

Assim, com o objetivo de dar prosseguimento às reflexões sobre o corpo, que ao ser submetido às investigações médicas envereda-se rumo às experimentações artísticas, será apresentada, no próximo subcapítulo, uma breve análise da poética de Frida Kahlo (1907-1954). 


\subsubsection{O corpo e as obras de Frida Kahlo}

A escolha pela abordagem de Frida Kahlo (1907-1954) parte das similitudes encontradas entre a proposta geradora dos trabalhos da artista e o tema das produções artísticas corpos hemangescritos pertinentes a esta pesquisa.

Magdalena Carmem Frida Kahlo (1907-1954) foi uma artista mexicana com uma biografia singular que, apesar de ser marcada por acidentes e doenças, conta com uma vasta produção artística. Ao longo de sua trajetória médica, Kahlo (ibid.) se submeteu a mais de trinta cirurgias com o intuito de minorar os sofrimento provenientes de seus problemas de saúde. O diário escrito pela autora torna-se uma das suas obras mais reconhecidas visto que este traz a narrativa de todas as investigações médicas, diagnósticos, tratamentos, dores e fatalidades que acometeram sua vida.

Com temáticas que partiam de suas vivências, Kahlo (ibid.) aprofundava suas abordagens em uma concepção artística e, porque não dizer, poética dos acontecimentos que a circundava. Dessa maneira, a escolha da marca de nascença hemangioma como corpus deste trabalho parece se aproximar da perspectiva da artista de que a vida pode influir diretamente na arte. $\mathrm{O}$ corpo com hemangiomas se propôs a afastar-se da abordagem médica que, aliás, foi o impulsionador dos primeiros registros fotográficos, que, posteriormente, enveredaram-se rumo a uma nova trajetória artística e poética.

Nota-se que o corpo se torna o tema mais recorrente das pinturas de Kahlo (ibid.). Assim, entende-se que o corpo retratado nas imagens pela artista pode ser entendido como um grande cenário que abrigava as construções realistas e surrealistas ${ }^{57}$ do seu universo, provocando as mais controversas sensações, percepções, sentimentos e leituras por parte do receptor. Segundo Pires (2005, p.28), "[..] o corpo é ao mesmo tempo lugar de produção da representação e de sua destruição: todas as imagens corporais são de imediato "surrealistas"." Logo, entende-se que os trabalhos artísticos de Kahlo instigam o receptor a se tornar o coautor das criações. Isso porque

\footnotetext{
57 Termo relativo a ou próprio de surrealismo. Surrealismo: s.m. (1929) HIST.ART: movimento literário e artístico, lançado em 1924 pelo escritor francês André Breton (1896-1966), que se caracterizava pela expressão espontânea e automática do pensamento (ditada apenas pelo inconsciente) e, deliberadamente incoerente, proclamava a prevalência absoluta do sonho, do inconsciente, do instinto e do desejo e pregava a renovação de todos os valores, inclusive os morais, políticos, científicos e filosóficos. Fonte: Dicionário Eletrônico Houaiss da Língua Portuguesa 3.0.
} 
suas representações artísticas parecem conceder abertura para as inúmeras interpretações que o receptor possa vir a ter. Para a autora:

São as imagens corporais que, na vida, de maneira acidental, provocam interferências com as representações do corpo na arte. Vamos ainda mais longe: são as imagens corporais que, na nossa própria vida, não deixam de restituir às representações artísticas do corpo seu poder visionário e alucinatório. A percepção estética não se caracteriza por uma posição prévia quanto ao objeto - no sentido trivial em que se fala do "olho do expert" -; ela acompanha as imagens corporais, constrói-se e destrói-se nas visões metafóricas do corpo. (PIRES, 2005, p.27).

O quadro intitulado O hospital Henry Ford, figura 14, também conhecido como "cama voadora", traz a artista deitada no leito do hospital, localizado em Detroit, EUA. Essa pintura parece representar algumas das tragédias e doenças que acometeram Kahlo, a partir de uma perspectiva artística.

Fig.14- Henry Ford Hospital (La cama volando/ A cama voadora). ${ }^{58}$

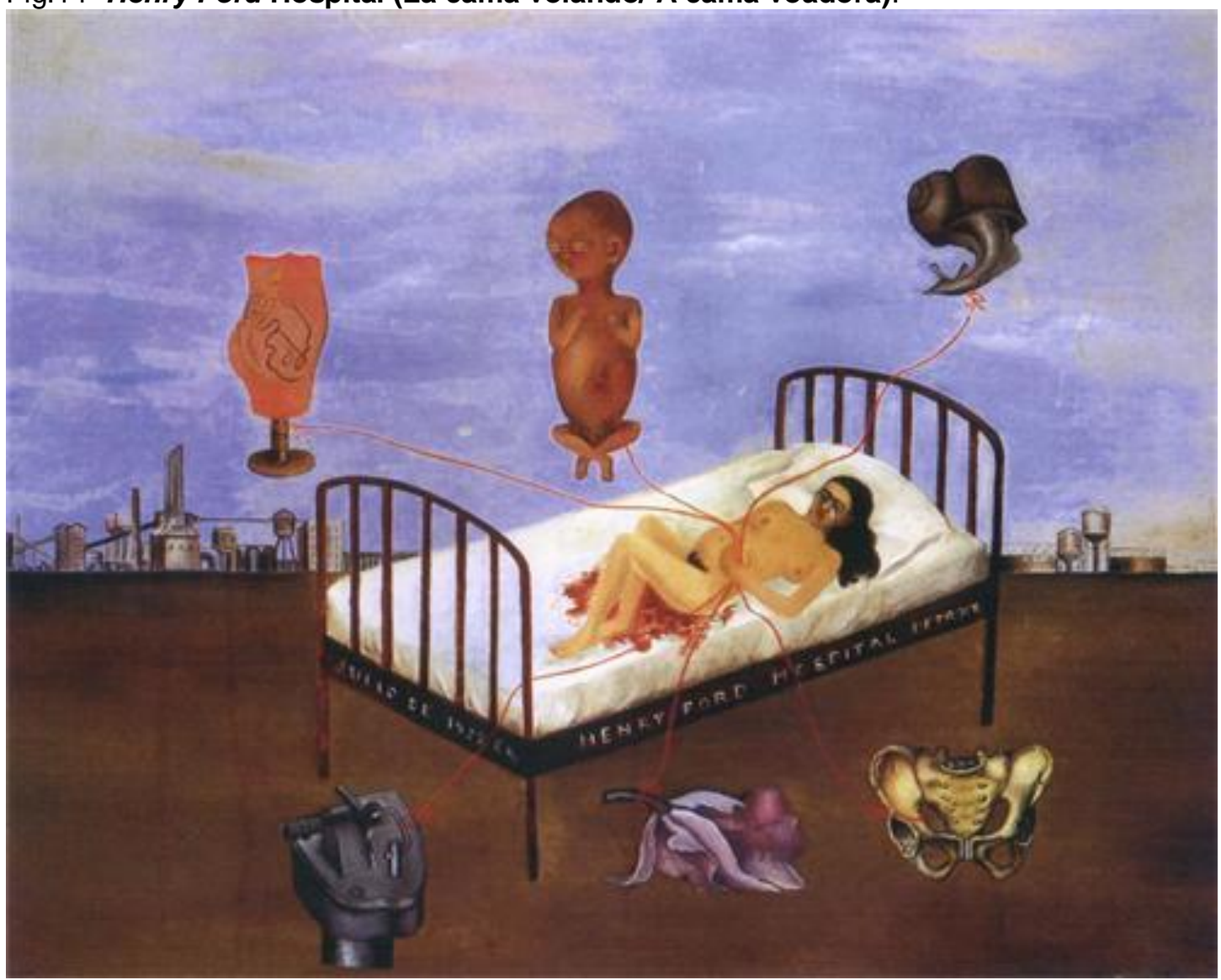

Obra: Magdalena Carmem Frida Kahlo, 1932.

${ }^{58}$ Disponível em: <http://www.wikiart.org/en/frida-kahlo/henry-ford-hospital-the-flying-bed-1932\#close> Acesso em: 8 set. 2014, 22:50:35. 
Na tentativa de descrição da referida pintura, Bezerra (2003) apresenta os seguintes elementos: (1) As seis figuras representadas no quadro, das quais três parecem flutuar sobre o leito (um caramujo, um feto do sexo masculino e um modelo anatômico de abdômen e de pelve) e as outras três que encontram-se no chão, abaixo da cama, (uma pelve óssea, uma flor e uma autoclave ${ }^{59}$ ), presas à mão esquerda da artista por meio de artérias, de modo que também aparentam vasos de um cordão umbilical; (2) O corpo representado demasiadamente pequeno em relação ao tamanho do leito hospitalar sugere seu grande sofrimento e solidão; (3) O lençol ensanguentado faz menção aos dois abortos sofridos por Kahlo; (4) A lágrima que goteja do olho da personagem parece simbolizar a dor de uma mãe pela perda de seus filhos; (5) A pelve óssea reafirma sua impossibilidade anatômica de ser mãe. Assim, podese afirmar que todas as figuras representadas na pintura parecem simbolizar e compor o cenário do grande sofrimento vivenciado pela artista.

Após conhecermos um pouco mais a respeito das abordagens artísticas de Frida Kahlo (1907-1954), entende-se que é possível aplicar novas roupagens a temas vivenciados pelo artista, ainda que no âmbito médico, e incorporá-los as suas construções artísticas e poéticas.

Baseando-se nessa perspectiva, o tópico a seguir traz a marca de nascença como um tema desenvolvido pelos artistas em suas produções na atualidade.

\subsubsection{A Marca de nascença no âmbito artístico}

A abordagem da marca de nascença no âmbito artístico parece ser um tema bastante precursor. No cenário contemporâneo, encontramos dois artistas que trabaIharam o tema com técnicas bastante diferenciadas.

A primeira obra trata-se de uma pintura intitulada "A marca de nascença azul", figura 15, do artista plástico Eduardo Sancinetti (1982-) ${ }^{60}$.

\footnotetext{
${ }^{59}$ MED aparelho que utiliza vapor de água sob pressão para esterilizar instrumentos. Fonte: Dicionário Eletrônico Houaiss da Língua Portuguesa 3.0.

60 O artista nasceu em 1982, em Piracicaba, São Paulo, onde atualmente reside e trabalha. Formouse em Artes Plásticas pela UNESP em 2006. Já participou de coletivas, como na galeria + Soma, publicou em revistas nacionais e internacionais, como a Moon Mag / China, Trip, Zupi e Simples. Participa de simpósios e coletivos variados de arte. "Cf." <http://www.yasni.info/ext.php?url= http\%3A\%2 F\%2Fcatalogodasartes.com.br>. Acesso em: 22 abril 2014. 21:40:18. Em 2010, Sancinetti realizou sua primeira coletiva intitulada Verde e Vermelho. Cf. <http://cargocollective.com/eduardosancinetti/ Vermelho-e-Verde>. Acesso em: 22 abril 2014. 23:28:24.
} 
Fig. 15 - "Marca de Nascença Azul". ${ }^{61}$

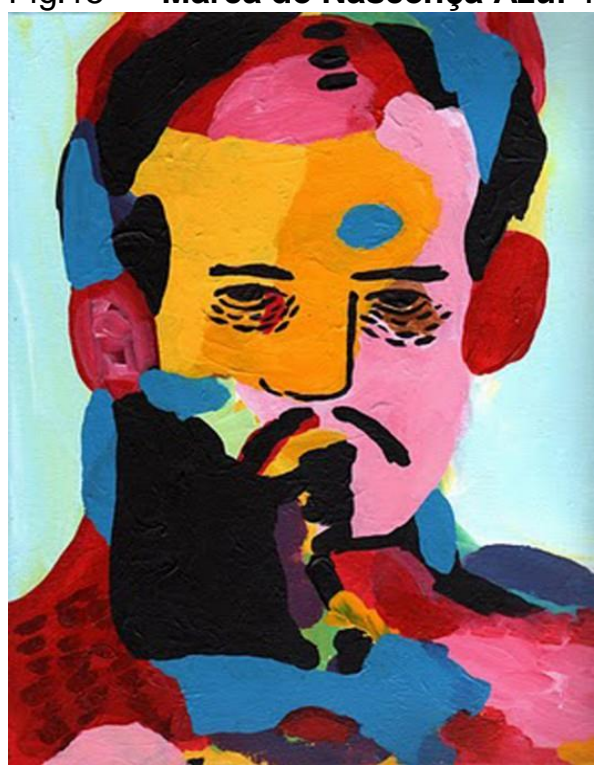

Imagem divulgação/ Obra: Eduardo Sancinetti Acrílica s/ tela - 24×30cm, 2010.

O segundo exemplo de produção relacionada com o tema, é de autoria da artista Paranaense Verlânia do Carmo (1994-) que trabalha com réplicas de bebês a partir da arte inglesa do reborn, que quer dizer renascer. Com o intuito de trazer um maior realismo a obra, a artista reproduz os minuciosos detalhes dos bebês encomendados, tais como cor dos cabelos, veias e até as marcas de nascença. Na foto abaixo, figura 16, pode-se notar uma réplica de um bebê com uma marca de nascença azulada entre os olhos.

Fig.16 - Réplica de bebê com marca de nascença. ${ }^{62}$

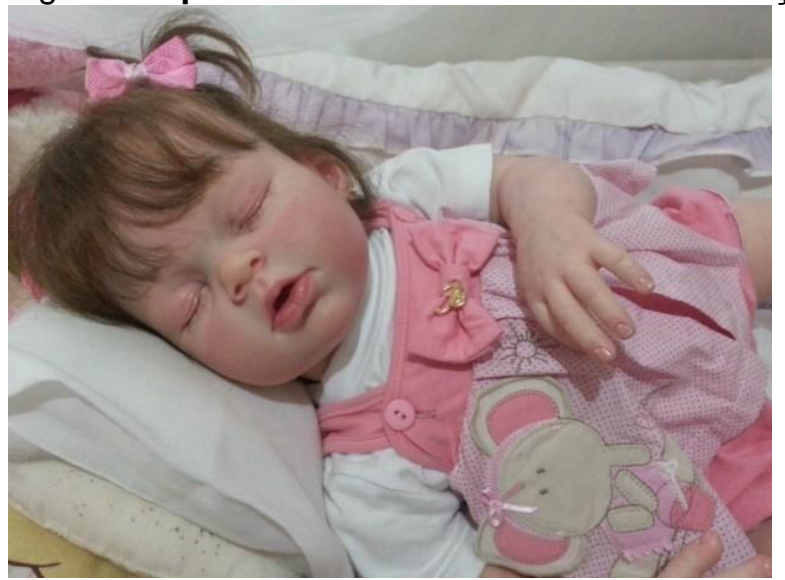

Foto: Luiz Haab/G1.

\footnotetext{
${ }^{61}$ Disponível em:

<http://vilamundo.org.br/2011/05/coletiva-na-galeria-mezanino-traz-retratos-e-autorretratos/> Acesso: 10 jul. 2013. 18:22:10.

62 Disponível em:

<http://g1.globo.com/pr/oeste-sudoeste/noticia/2014/03/bebes-de-plastico-feitos-por-artista-tem-veiase-ate-marcas-de-nascenca.html>. Acesso em: 22 abril 2014. 21:25:30.
} 


\subsection{Abordagens tecnológicas: construção de diálogos artísticos}

Sabe-se que o estreitamento das relações entre o corpo e a arte continua ampliando-se de maneira extremamente complexa em nossa atualidade. As inquietações, acontecimentos, vivências, experimentações e fruições do corpo continuam a ser estudadas e teorizadas, tanto em suas ações quanto em suas concepções. $O$ corpo, impregnado de marcas concretas e subjetivas, continua a construir experimentações artísticas que dialogam com as potencialidades do universo tecnológico. Diante da imersão da arte no âmbito tecnológico, ou vice-versa, o corpo é um dos temas centrais das abordagens tecnológicas da atualidade: cibercorpo, telepresença, vida artificial, interatividade, ciberespaço, realidade virtual e outras possibilidades.

Questões espaciais sofreram transformações substanciais, e a produção de arte contemporânea se permite estabelecer relações imediatas com o mundo, sem abandonar, contudo, o seu mundo interior. A ampliação do espaço de ação do artistapesquisador contemporâneo indica caminhos investigativos repleto de reformulações quanto aos suportes artísticos tradicionais. Esse artista dialoga com novas expressões artísticas e com a reorganização do papel do receptor, incluindo, ainda, pesquisas direcionadas ao contexto espacial com relevantes contribuições para a construção de poéticas.

A partir dessa abordagem, segue-se rumo à fotografia, a fim de que, a partir da compreensão das mudanças de seus paradigmas, possamos refletir sobre os seus novos diálogos com as possibilidades artísticas e tecnológicas. A partir dessa contextualização, conseguiremos vislumbrar o quanto os recursos fotográficos, beneficiados pela Arte e tecnologia, transcenderam sua funcionalidade de captação de imagens rumo à novos suportes e possibilidades construtivas.

\subsubsection{Arte e Tecnologia}

Voltando-se para a relação entre arte e tecnologia, Zamboni (2006) afirma que a grande maioria das inovações e descobertas tecnológicas não foram desenvolvidas para o uso específico em artes, mas foram sendo incorporadas pelo fazer artístico. Segundo o autor, a fotografia é um exemplo disso visto que foi criada com o objetivo de registro de imagens, e, posteriormente, começou a ser utilizada, entre outras funções, como uma linguagem artística. 
Sabe-se que, desde suas origens, a fotografia e a arte parecem manter uma estreita relação entre si, pois, apesar desses dois campos de expressão possuírem sua relativa autonomia enquanto linguagem, elas parecem, por vezes, relacionar-se por meio de ambiguidades, tais como: atração e/ou repulsa; incorporação e/ou separação, dentre outros aspectos em sua trajetória.

Durante um período essencial do século XIX, pode-se afirmar que a fotografia vivia numa relação de aspiração rumo à arte? Annateresa Fabris (2008) destaca que se por um lado existia um discurso realista por parte da fotografia, por outro, havia fotógrafos como Julia Cameron, Gustave Le Gray, dentre outros que exploravam as possibilidades plásticas do meio, em busca de efeitos artísticos, frequentemente interpretados com critérios extrafotográficos. Para a autora (2008), Talbot ${ }^{63}$ foi um dos primeiros a defender a utilidade da fotografia tanto para o artista quanto para a documentação da obra de arte.

Degas (1834-1917) é um grande exemplo de artista do século XIX apontado por Fabris (2008) que conseguiu trabalhar efetivamente com a fotografia vendo nela mais do que um simples apontamento. Enquanto fotógrafo, Degas encontrou no instantâneo as mesmas qualidades que pretendia explorar na própria pintura: imediatez, fragmentação e espontaneidade.

No início do Século XX, os artistas dos movimentos de Vanguarda Européia já começavam a utilizar a imagem fotográfica em experimentações estéticas inovadoras. A partir dessa afirmativa, pode-se apontar uma inversão da aspiração hipotética da fotografia rumo à arte? Ao longo do século $\mathrm{XX}$, seria a arte que insistiria em se impregnar de certas lógicas da fotografia?

Segundo Dubois (2012), uma parte muito importante da arte contemporânea, bem como, a inovação, a experimentação e a pesquisa de novas linguagens, podem ser consideradas, em particular, desde Marcel Duchamp (1887-1968). Isso porque este artista é a personalidade que assinala a mudança como uma evolução rumo a uma radicalização da lógica incidiária. Provavelmente, Duchamp (ibid.) jamais foi fotógrafo sensu stricto, mas toda a sua obra pode ser considerada como "conceitualmente fotográfica", isto é, conduzira uma evolução rumo a uma radicalização da lógica indiciária. Ou melhor, trabalhava por uma lógica do índice do ato e do traço, do signo fisicamente ligado a seu referente antes de ser mimético. Sua

${ }^{63}$ W.H.Fox Talbot, The Pencil of Nature, New York, 1969, s.p. apud Annateresa Fabris, 2008, p.175. 
obra, embora complexa e multifacetada, aparece historicamente como a pedra fundamental no entendimento das relações entre fotografia e arte contemporânea.

\subsubsection{Arte e Fotografia}

A partir do entendimento da fotografia no cenário contemporâneo, cujos recursos podem favorecer a renovação, ampliação e a busca por novas atuações nos mais diferentes âmbitos, apresenta-se o trabalho do fotógrafo Davis Ayer que tem enveredado suas práticas fotográficas rumo à apropriação de linguagens artísticas.

Davis Ayer é um fotógrafo americano que vem se destacando no cenário internacional por utilizar a fotografia e a arte em seus trabalhos. Um dos seus projetos de maior originalidade surgiu a partir de projeções de imagens em corpos femininos.

A maioria das criações de Ayer, conta com a interação de elementos fotográficos e artísticos que resultam em fotografias. Estas, além da originalidade na abordagem dos temas, possuem um primoroso trabalho de composição, iluminação, manipulação de imagens, dentre outros elementos e/ ou recursos tecnológicos. As figuras 17, 18 e 19 são exemplos da série fotográfica intitulada Time Travel / em que Ayer parece misturar paisagens fotográficas, paisagens urbanas e imagens usando o corpo como o suporte e a tela.

\section{Fig.17- Sem Título. ${ }^{64}$}

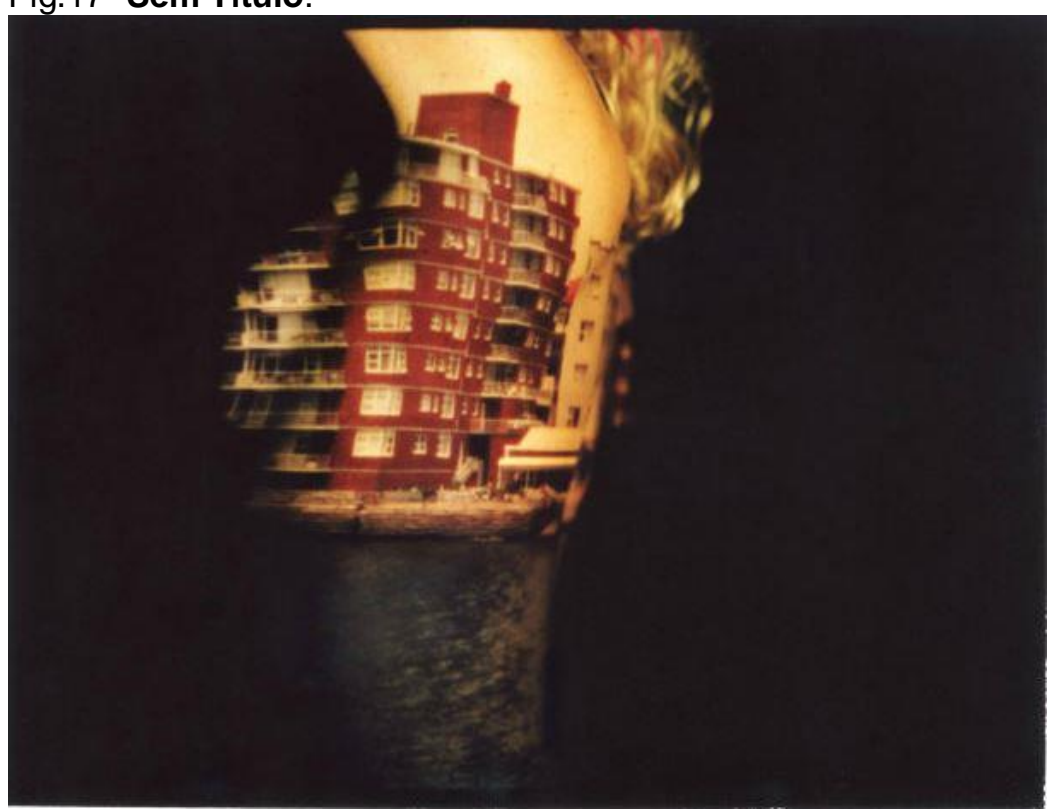

Foto: Davis Ayer. Portfólio:Time travel I.

${ }^{64}$ Disponível em: $<\mathrm{http}: / / w w w$. davisayer.com/\#a=0\&at=0\&mi=2\&pt=1\&pi $=10000 \& s=0 \& p=5>$ Acesso em: 26 abril 2014. 23:23:11. 
Fig.18 - Sem Título. ${ }^{65}$

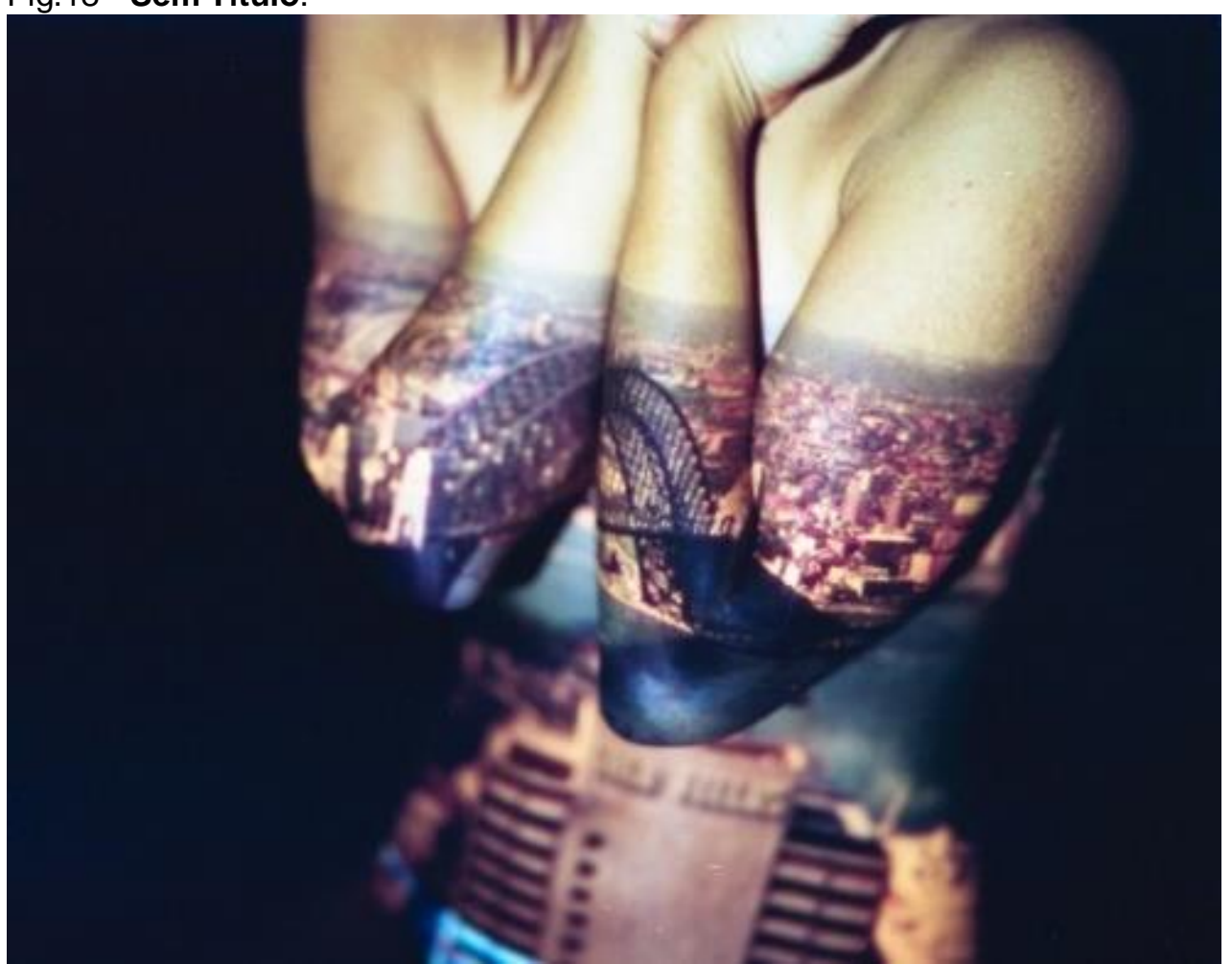

Foto: Davis Ayer. Portfólio:Time travel I.

Fig.19- Sem Título. ${ }^{66}$

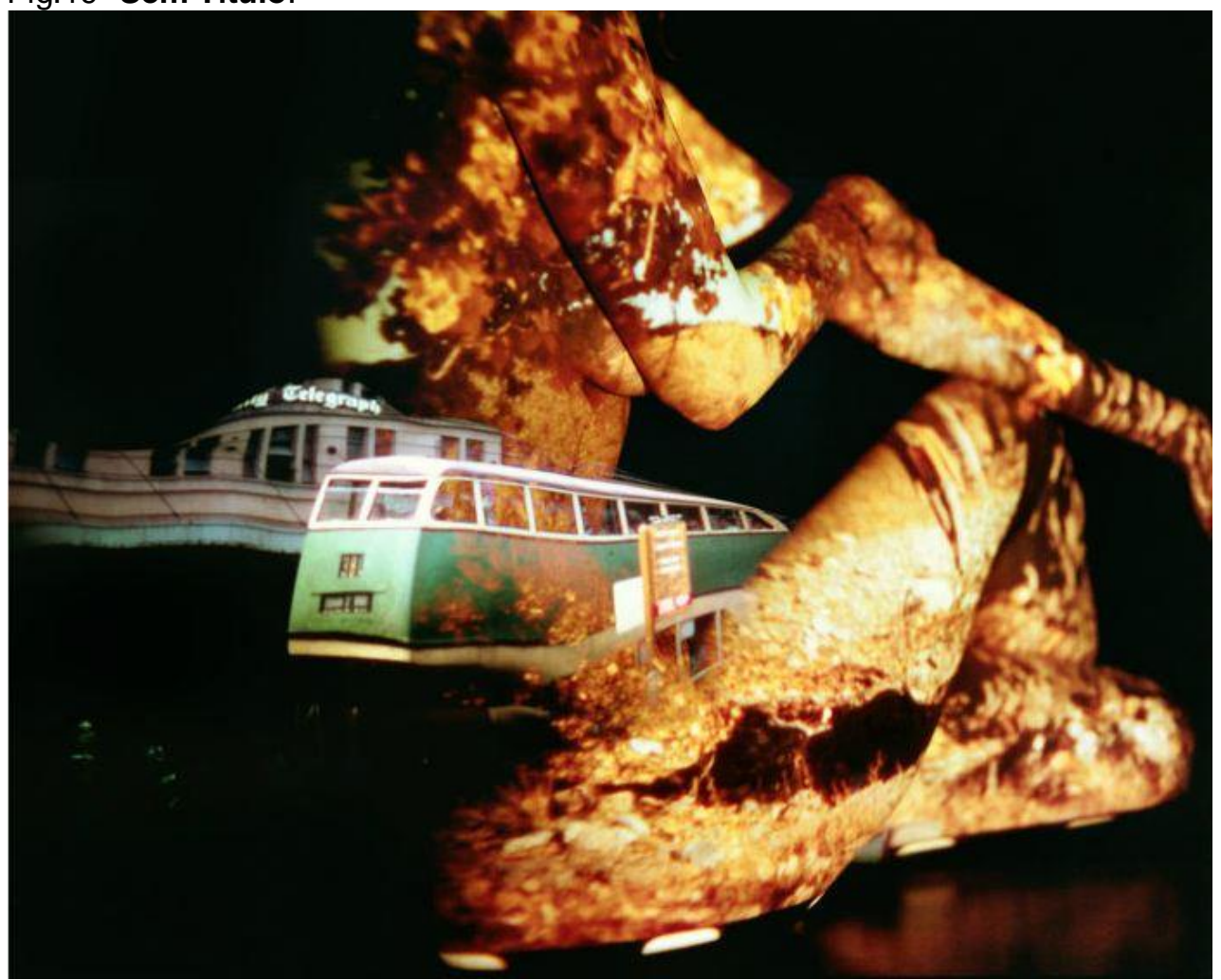

Foto: Davis Ayer. Portfólio: Time travel I.

${ }^{65}$ Disponível em: $<\mathrm{http}: / /$ www.davisayer.com/\#a=0\&at=0\&mi=2\&pt $=1 \& \mathrm{pi}=10000 \& \mathrm{~s}=0 \& \mathrm{p}=5>$ Acesso em: 26 abril 2014. 23:35:12.

${ }^{66}$ Disponível em:<http://www.davisayer.com/\#a=0\&at=0\&mi=2\&pt=1\&pi=10000\&s=0\&p=5> Acesso em:26 abril 2014. 23:46:21. 
Nota-se que as fotografias criadas por Ayer, a partir das projeções nos corpos femininos, resultam em composições extremamente poéticas. Nesse sentido, podese afirmar que essas construções podem ser melhor compreendidas ao direcionarmos nossos foco de estudo para o olhar, visto que ele exerce um papel ativo tanto na percepção do fotográfo quanto na recepção das fotografias.

Assim, em continuidade a essas reflexões no âmbito fotográfico, verifica-se que para Barthes (1984), a foto pode ser objeto de três práticas (ou de três emoções, ou de três intenções): fazer, suportar, olhar. Sendo assim, com o intuito de ampliar o estudo da relação que a fotografia estabelece com o olhar, voltamo-nos, primeiramente, para o estudo do olho proposto por Dawkins.

Na obra $A$ escalada do Monte Improvável, Richard Dawkins ${ }^{67}$ nos convida a reflexão do olho enquanto organismo biológico.

Tem sido autoritariamente estimado que os olhos evoluíram não menos de quarenta vezes, e provavelmente mais de sessenta vezes, independentemente em várias partes do reino animal. Em alguns casos, esses olhos empregam princípios radicalmente diferentes. Nove princípios foram reconhecidos entre os quarenta a sessenta olhos desenvolvidos independentemente. (DAWKINS, 1998, p.158).

A partir da estimativa evolutiva dos olhos, começamos a mensurar a real complexidade de nossos olhos enquanto órgão biológico. Entendemos, portanto, que os olhos humanos são órgãos fotossensíveis que atingiram um alto grau evolutivo e, por isso, dotaram-se de um complexo sistema estrutural. Segundo Dawkins (1998), lentes, assim como os próprios olhos, parecem ter evoluído diversas vezes independentemente.

Dawkins (1998) também explica que olhos formadores de imagem de alta resolução não seriam adequados a animais muito pequenos. Isso se deve ao fato de que os olhos de alta qualidade não estariam relacionados com o corpo do animal, mas teria que exceder certo tamanho-absoluto e, quanto maior, melhor. Sendo assim, animais muito pequenos não poderiam carregá-los. Em uma análise comparativa com o reino animal, percebemos que o olho humano é órgão com proporções perfeitamente

${ }^{67}$ Richard Dawkins (1998) afirma que a construção do capítulo sobre a evolução dos olhos baseou-se na conclusão de Michael Land, autoridade no assunto, de que os olhos evoluíram, pelo menos, quarenta vezes independentemente em diferentes partes do reino animal. Cf. Land, M.F. "Optics and vision in invertebrates". In Handbook of sensoru physiology. (ed.H. AUTRUM) Berlim, Springer-Verlag, 1980, VII / 6B, 471-592. 
adequadas ao seu funcionamento. $E$ isso se deve ao fato de que esse órgão possui o tamanho-absoluto ocular ideal que comporta olhos avançados, com uma visão de alta resolução e qualidade.

É sabido que os olhos, de natureza orgânica, são os órgãos responsáveis pela nossa visão; ação ou efeito de ver. Ampliando analogicamente esse conceito, podemos afirmar que os olhos humanos são como "lentes fotográficas" com alto poderio de captação de imagens e resolução high-tech?

Richard Dawkins (1998) declara que a pupila68 de um olho humano é um equipamento de tecnologia automatizada bastante sofisticado, algo de que se orgulharia um engenheiro de microeletrônica japonês. De acordo com o autor, essa afirmação pode ser verificada ao termos um facho de luz apontado para nossos olhos enquanto o observamos no espelho. Notar-se-á que as pupilas humanas respondem rapidamente.

Em continuidade a esse entendimento, Dawkins (1998) apresenta o sistema de sofisticação utilizado pelo olho e pela câmera fotográfica no processo de focalizar. Para tanto, afirma que uma câmera automática ou um olho possuem um medidor de luz embutido que mantém automaticamente o orifício estreito quando o sol aparece, e o alarga quando o sol se esconde. Isso acontece porque, para determinada sensibilidade de filme ${ }^{69 /}$ fotocélulas ${ }^{70}$, é possível haver muita (ofuscação) ou pouca luz. Na câmera, o orifício através do qual a luz entra, é chamado de diafragma. Portanto, tanto na câmera quanto nos olhos, quanto mais estreito o orifício, melhor é a profundidade do foco - o conjunto de distâncias que estão em foco simultaneamente.

\footnotetext{
${ }^{68}$ A pupila é um orifício situado no centro da íris, que, ao se contrair ou dilatar, permite regular a quantidade de luz que penetra no olho. Fonte: Dicionário Eletrônico Houaiss da Língua Portuguesa 3.0

69 Segundo Dawkins (1998), as câmeras digitais não usam filme. Assim, a luz é registrada num chip eletrônico localizado atrás da lente. O chip capta a luz sob a forma de uma imagem composta por pontos, chamados pixels.

70 Para Dawkins (1998), olhos avançados como os nossos possuem milhões de fotocélulas densamente empilhadas, como felpas em um carpete, e cada uma delas está programada para captar o maior número de fótons possível. O autor acrescenta que a retina humana possui aproximadamente 166 milhões de fotocélulas divididas em vários tipos. Dividem-se basicamente em bastonetes (especializados na visão em branco e preto de pouca precisão, sob luminosidades relativamente baixas) e cones (especializados na visão em cores de alta precisão, em luminosidade intensa). Explica, ainda, que, enquanto lemos essas palavras, nós estamos utilizando os cones. [..] Os cones se concentram em uma pequena região central chamada fóvea (então estamos lendo com nossas fóveas) onde não existem bastonetes. Essa é a razão pela qual não se deve focalizar os olhos diretamente para um objeto de luminosidade fraca como o cometa de Halley, para que sua luz escassa não incida sobre a fóvea.
} 
Com o objetivo de possibilitar uma visualização comparativa do sistema de captação de luz entre pupilas de animais, do olho humano e o diafragma de uma câmara, apresenta-se a seguinte ilustração:

Fig.20 - Várias pupilas, incluindo diafragma de uma câmara. $O$ formato exato da pupila não é importante, por isso ele é tão diversificado: (a) píton reticulada; (b) bicuda verde; (c) gato; (d) humano; (e) câmara fotográfica.
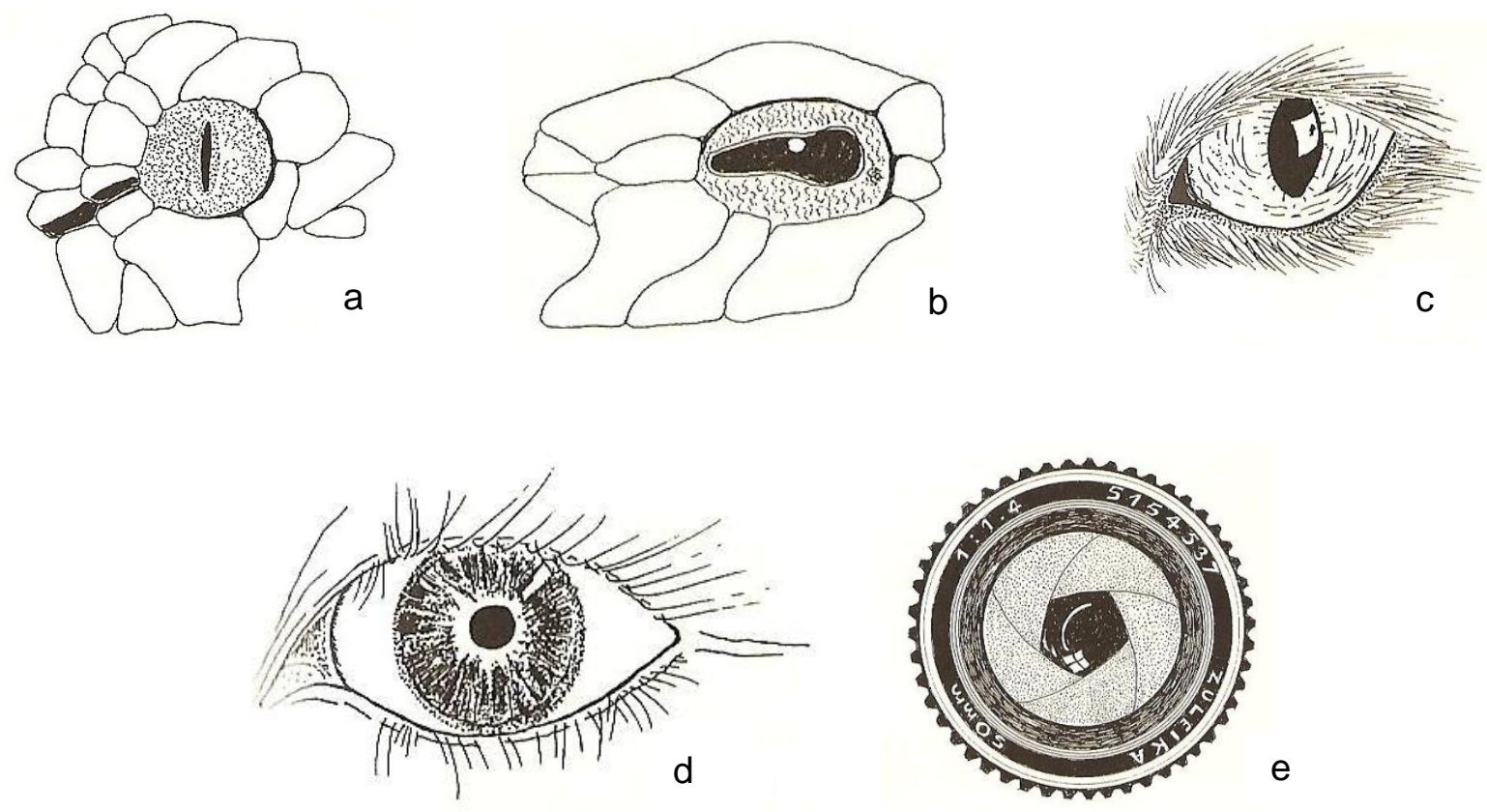

Fonte: DAWKINS, Richard, 1998, p.189. Ilustração com Adaptações.

Dawkins (1998) afirma que o olho humano é um olho do tipo câmera. Um olho do tipo câmera forma uma imagem de ponta-cabeça. A imagem de um olho composto ${ }^{71}$ está em posição correta. Encontrar um intermediário entre essas duas imagens é uma proposta árdua, falando em termos amenos. Um intermediário possível é a ausência de imagens. Assim, alterar o tamanho do diafragma modifica a distância e a qualidade de visibilidade do foco.

Ampliando a analogia entre os olhos e as lentes fotográficas, percebemos que, em muitas situações, a tecnologia baseou-se na complexidade do sistema ocular como um elemento referencial para invenção de máquinas com capacidade de captação imagética. Por exemplo, as lentes das câmeras fotográficas, chamadas objetivas,

\footnotetext{
${ }^{71}$ Dawkins (1998) explica que o olho composto é um órgão visual encontrado em certos artrópodes como insetos e crustáceos.
} 
permitem a melhoria na qualidade de focalização das imagens de acordo com a meIhoria de suas características.

O recurso da Lente zoom, por exemplo, permite variar a distância focal, e como consequência, a variação do campo abrangido e o tamanho da imagem. Naturalmente, focalizamos aquilo que nos chama atenção; o que nos apreende o olhar. Ao menor sinal de interesse, nossos olhos ou "lentes orgânicas" ou ainda "lentes orgânicas zoom" também utilizam a sua sofisticação a fim de capturar e/ ou esgotar as possibilidades de observação.

Caso entendamos que fatores internos individuais são capazes de influir sobre nossa maneira de enxergar o mundo, pode-se afirmar que os fatores emocionais também influenciam nosso olhar sobre a fotografia? Barthes (1984) discorre sobre a influência de uma tábua interior de gostos, desgostos e indiferenças que todos nós possuímos e que nos leva a compreender o interesse pela fotografia. Nesse trecho, 0 autor descreve algumas pistas:

[..] Eu parecia com esse amigo que só se voltara para a Foto porque ela lhe permitia fotografar seu filho. Como Spectator, eu só me interessava pela Fotografia por "sentimento"; eu queria aprofundá-la, não como uma questão (um tema), mas como uma ferida: vejo, sinto, portanto, noto, olho e penso. (BARTHES, 1984, p.39).

Em uma tentativa de explicitar a "co-presença" dos elementos que parecem fundar seu interesse pelas fotografias, Barthes (1984) apresenta o studium e o punctum. Segundo o autor, o studium pode ser entendido como "a aplicação a uma coisa, o gosto por alguém, uma espécie de investimento geral, ardoroso, é verdade, mas, sem acuidade particular" (op. cit., p.44). Ele pode ser entendido como uma espécie de interesse geral que pode ser "culturalmente" despertado no ser humano; surge do "desejo indolente, do interesse diversificado, do gosto inconsequente: gosto/ não gosto...".

Ao contrariar o primeiro elemento, ainda que as duas abordagens não sejam excludentes, o punctum é apresentado como o interesse demasiadamente íntimo e emotivo que não precisa ser buscado, visto que, segundo o autor, ele parece partir da cena como uma flecha que vem para transpassar. Para Barthes, a palavra em latim punctum que designa "[..] essa ferida, essa picada, essa marca feita por um instru- 
mento pontudo [..]" torna-se ainda mais apropriada ao trazer, também, a ideia de pontuação que, de maneira literal, faz com que as fotos sejam, de fato "[..] como pontuadas, às vezes até mesmo mosqueadas, com esses pontos sensíveis; essas marcas, essas feridas são precisamente pontos” (op. cit., p.46). De maneira conclusiva, a função do punctum na fotografia pode ser melhor compreendida a partir da seguinte definição de Barthes: "O punctum de uma foto é esse acaso que, nela me punge (mas também me mortifica, me fere)". (loc.cit.).

Em continuidade às abordagens da fotografia no campo emotivo, ao analisar o personagem Kafka, Barthes (1984) apresenta a definição da consciência afetiva. No trecho em que Kafka é questionado quanto ao olhar sobre a fotografia, sua resposta traz uma perspectiva baseada na introjeção do olhar, que ele descreve como uma maneira de fechar os olhos frente a suas histórias.

[..] No fundo -ou no limite- para ver bem uma foto mais vale erguer a cabeça ou fechar os olhos. "A condição prévia para a imagem é a visão.", dizia Janouch a Kafka. E Kafka sorria e respondia: "Fotografam-se coisas para expulsá-las do espírito, minhas histórias são uma maneira de fechar os olhos. (BARTHES, 1984, p. 84).

A partir dessa contextualização, o autor afirma que a foto que o toca é aquela que quando ele a retira do seu contexto costumeiro; ela não tem nada a dizer. Assim, apenas fecha os olhos (fechar os olhos é fazer a imagem falar no silêncio) e deixa o detalhe remontar sozinho à consciência afetiva.

Ainda com relação ao interesse pela fotografia, pergunta-se quem nunca fixou o olhar em uma foto que parecia trazer uma estranheza no corpo de alguém ou mesmo em algum elemento atípico? A visão parece fechar instantaneamente a sua "objetiva da lente orgânica" em um certo enquadramento. A sensação parece ser dificilmente descrita, mas é como se toda a iluminação que circunda aquele certo ponto de destaque do olhar tivesse sido apagada.

Para Dubois (2012), a fotografia é uma curiosa questão de luz, ou melhor, de circulação de luz. E, para se fazer um retrato, faz-se necessário ter luz para iluminar o sujeito. Em contrapartida, é necessário que esse mesmo sujeito irradie, ou mesmo, que emane dele luz para atingir e queimar essa "película tão sensível", tão reativa às suas emanações que ela conservará sua impressão. 
No entanto, paradoxalmente a esse processo, o autor esclarece que a revelação faz-se na câmera escura. Isso porque é necessário que essa luz deixe de ser, a fim de que a imagem apareça finalmente. Assim, a luz é necessária ao surgimento da imagem, apesar de que, paradoxalmente, ela mesma pode ser responsável por desaparecer, apagar ou eliminar a imagem por inteiro. Portanto, é preciso se proteger dela tanto quanto procurá-la. No trecho a seguir, encontramos o processo de transformação da luz referida pelo autor.

[..] Uma vez captada e engolida a irradiação luminosa originária, a caixa negra volta a se fechar com solidez e a luz captada vai se transformar aos poucos em imagem. A alquimia fotográfica vai metamorfosear a luz em cor. É isso, o tráfego, o intercâmbio, o desprendimento, o "milagre da transubstanciação". $E$ isso pode continuar a trafegar, pode ser válido de uma imagem à outra, por exemplo, da imagem latente à imagem revelada, de um negativo a um positivo, de uma fotografia à outra, ou de uma pintura a uma fotografia. (DUBOIS, p. 221-222).

Assim, afirma-se que no processo da fotografia existe uma transformação fundamental, uma questão de transferência, de transmutação. Isso porque a luz captada se transformará aos poucos em imagem visto que a "alquimia fotográfica" irá metamorfosear a luz em cor. No entanto, essa transubstanciação continuará a trafegar na passagem de uma fotografia à outra, ou de um a pintura a uma fotografia, dentre outros processos. De maneira conclusiva, entende-se, portanto, que o corpo fotográfico nasce e morre na luz e pela luz. Essa concepção conduzirá as experimentações artísticas e fotográficas - macroimpressões artísticas - assim como, as reflexões teóricas desenvolvidas ao longo do próximo capítulo. Isso porque a luz se faz presente em todo o processo das produções artísticas, tais como: a projeção do hemangioma nos corpos, a composição fotográfica, a fotografia, assim como a fusão das projeções. 


\section{CAPÍTULO 3 \\ MACROIMPRESSÕES ARTÍSTICAS}

Proposto como corpus desta pesquisa, minha marca de nascença denominada hemangioma protagoniza as construções artísticas desenvolvidas neste capítulo. A escolha pelo uso da primeira pessoa, neste contexto, objetiva delimitar o término do "distanciamento" adotado ao longo das abordagens teóricas. Nos dois primeiros capítulos, o conto The Birthmark - 'A marca de nascença', de Nathaniel Hawthorne (1804-1864) se tornou o paradigma poético das construções propostas. Sendo assim, entendo que a referida mudança de pessoa textual, neste capítulo, pode tanto me referenciar enquanto artista possuidora do hemangioma, bem como contextualizar o uso do "sensível" em minhas construções poéticas e artísticas sobre o tema.

No transcorrer do estudo teórico, as marcas de nascença foram entendidas como macroimpressões do corpo. Dessa maneira, as macroimpressões apropriadas dos recursos artísticos e tecnológicos assumem uma nova roupagem e fomentam as produções artísticas propostas neste trabalho. Logo, as macroimpressões artísticas se constituem nesse processo a partir do diálogo entre o hemangioma, a fotografia, a projeção e a convergência de imagens projetadas simultâneas que objetiva tanto agregar novas possibilidades artísticas quanto estimular as reflexões pertinentes a essas produções.

Faz-se importante salientar que as temáticas e os recortes utilizados no decorrer do processo criativo se consolidaram a partir das abordagens estudadas ao longo desta pesquisa. Quanto às ferramentas de produção, estas foram corporificadas a partir da interação entre as possibilidades da Arte e Tecnologia em convergência com o tema hemangioma.

Ao longo das construções textuais deste capítulo, é notório o emprego do neologismo em certas palavras justamente pelo conteúdo extremante criativo, artístico e poético que elas carregam. Nesse sentido, a licença poética que usufruo enquanto artista me permitiu adentrar o universo linguístico e aplicar novos significados assim como prefixos e sufixos às raízes das palavras cuja junção pudesse potencializar a força emotiva que não foi encontrada em nenhuma outra palavra de nosso vocabulário. Tais palavras, bem como expressões, serão destacadas com a presença do seguinte símbolo $\left(^{*}\right)$. 


\subsection{O hemangioma e sua poética nas produções artísticas}

\subsubsection{A poética do nascimento do hemangioma}

Assim como as nuvens migram de uma extremidade a outra na infinita abóboda celeste, inicialmente, meu informe hemangioma parece ter transitado com seu carregamento pelos tecidos do meu corpo até que em uma dada localidade decidiu repousar. Uma vez enraizado, ele parece ter ganho territorialidade lançando-se rumo a sua formação constitutiva, bem como à delimitação de seus contornos e limites. $O$ seu avanço territorial e a dilatação das estruturas afetadas foram acontecendo em um processo extremamente lento, e sua dominação ocorreu concomitantemente ao crescimento estrutural dos órgãos que esse acometimento acabou por sujeitar.

Nascidos de desordens, meus hemangiomas parecem não ter conseguido deter sua própria fonte propulsora, ramificando-se rumo ao inescrutável. Sem se preocupar com suas expansões parasitárias, eles parecem ter crescido, agregado elementos e tomado posse da porção corporal cúmplice de suas metamorfoses estruturais. Nesse processo de conquista, os órgãos acometidos foram subjugados e adquiram suas características de caráter dominante que, finalmente, originou suas formas, seus volumes, suas delimitações.

Figs. 21 e 22- Marcas de nascença 1 e 2.
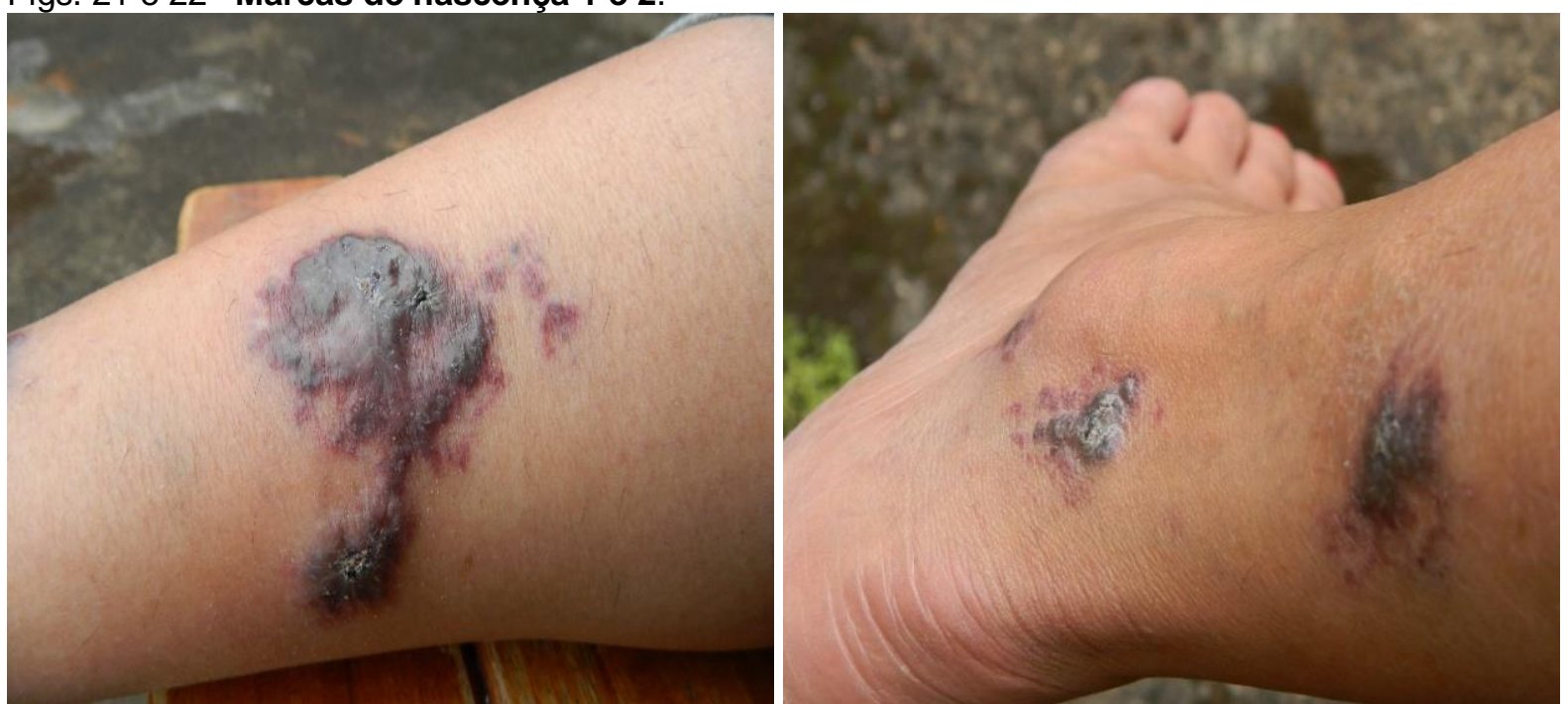

Foto: P.R. Freitas. Local: Brasília, 27 maio 2012. 


\subsubsection{A poética das formas e cores do hemangioma}

Como definir a multiplicidade de formas do meu hemangioma? Seria a palavra deformação e/ou mudança e/ou alteração na forma e/ou mesmo no meu sistema vascular o ponto de partida para tal entendimento?

Assim como em uma vitrine, sob o domínio dessa anomalia, minha pele parece exibir alguns percursos específicos de minhas estruturas vasculares. $O$ entretecimento entre os "fios pele"* e os "fios aglomerados venosos"* parecem tecer "tramas hemangiotecidos"* sem precedentes. Nesse contexto, posso afirmar que minha "vitrine-pele"* acaba por exibir muito além do que as resultantes estéticas do meu hemangioma; ela revela sua essência constitutiva. Isso porque, se entendo que é no sangue que o ser humano poeticamente carrega o néctar de sua existência, não posso afirmar que, quando o olhar do outro vislumbra o "néctar sanguíneo"* do hemangioma que the cria formas, desenhos, contornos, marcas e impressões, sua essência foi revelada?

Tal conjectura pode ser comparada com uma apresentação teatral em que, não apenas o palco, mas todos os acontecimentos dos bastidores podem ser vistos pelo público durante o espetáculo. Dessa maneira, a exposição dos bastidores se misturariam com as atuações dos atores em um verdadeiro desornamento informativo e visual. O mesmo parece ocorrer com o processo formativo do hemangioma visto que as estruturas encarregadas de ocultar o conteúdo parecem descortinar-se através da pele, revelando toda a enigmática essência sanguínea de seus bastidores.

Fig.23- Marcas de nascença: recortes.

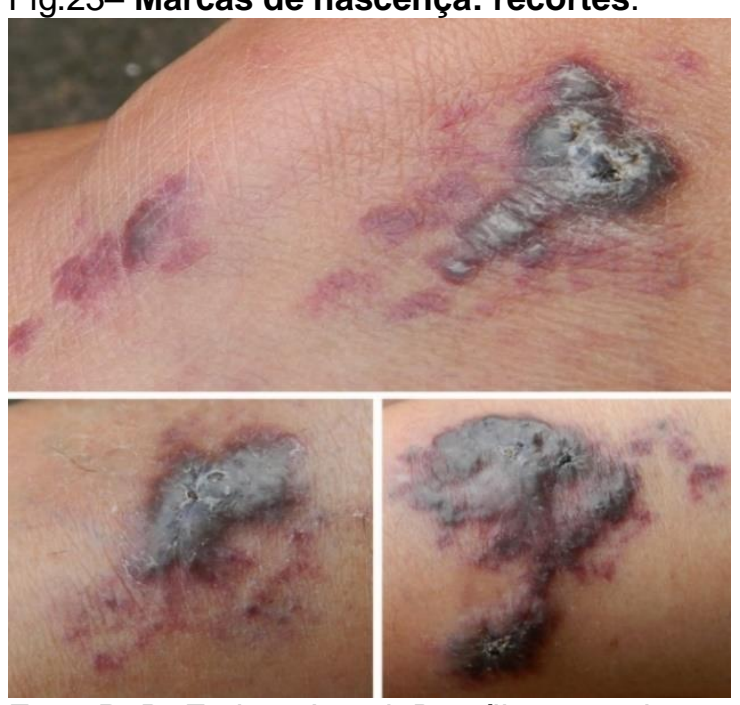

Foto: P. R. Freitas. Local: Brasília, 27 maio 2012.

Edição: Tatiana Rodrigues. Programa: Picasa 3.0. 
$\mathrm{Na}$ "tela da minha pele"*, as cores são compostas pela "paleta sanguínea $\mathrm{O}+$ "* de tons e matizes que variam, de acordo com as formações cavernosas e planas do hemangioma, entre o avermelhado e arroxeado. Quando submetidos a mudanças climáticas de grande significância, os "desenhos venosos"* do meu hemangioma apresentam nítidas alterações de cores em sua "paleta sanguínea"*. As figuras 24 e 25 mostram a "paleta sanguínea"* de tons predominantemente avermelhados incorporada pelo hemangioma na cidade de Goiás Velho.

Figs. 24 e 25- Marcas de nascença avermelhadas.

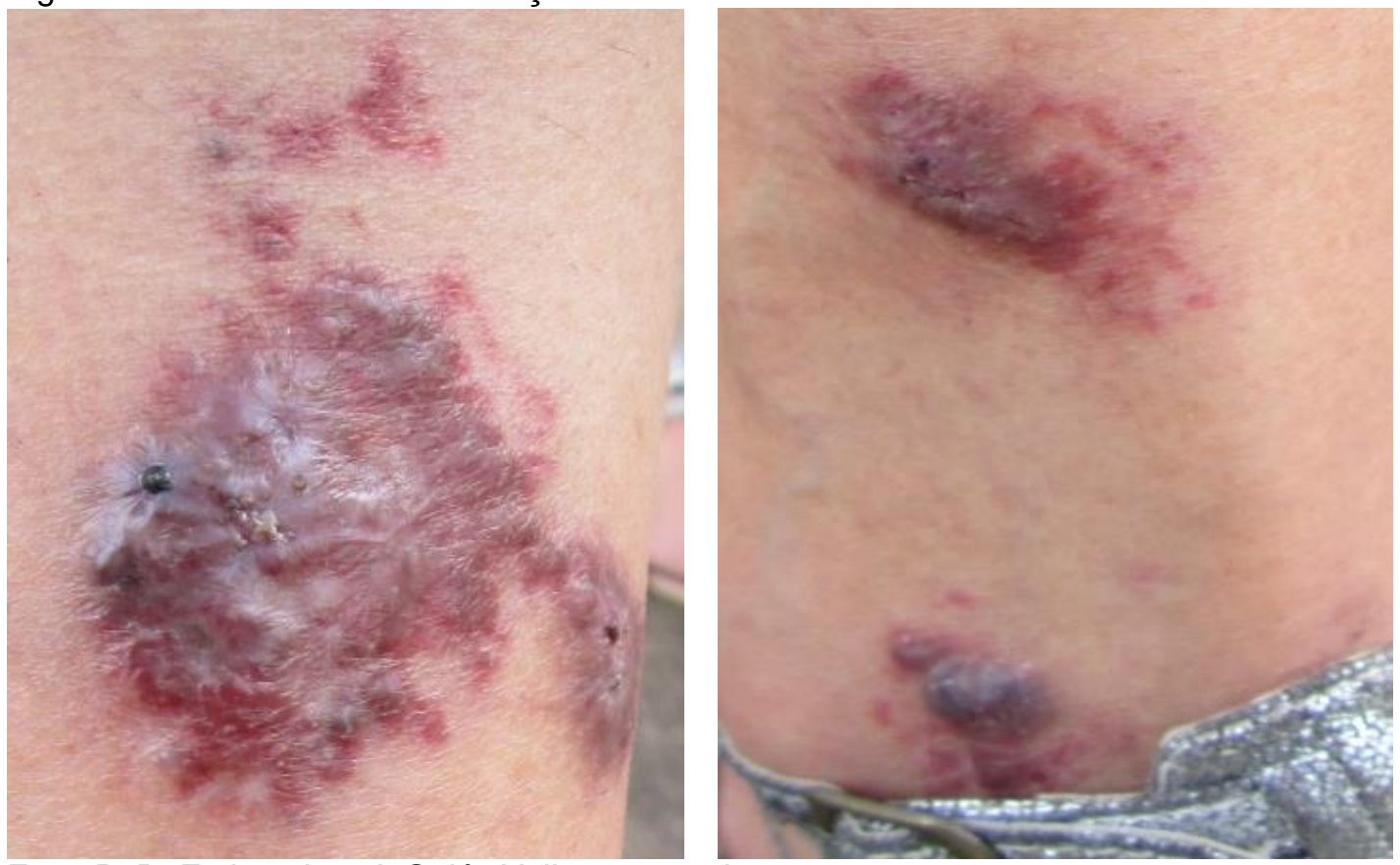

Foto: P. R. Freitas. Local: Goiás Velho, em 29 dez. 2011.

Caso o percurso sanguíneo do meu acometimento seja interrompido em consequência de uma forte compressão e/ou trauma local, as partes que foram submetidas a tais condições desaparecerão momentaneamente, modificando, assim, o seu aspecto formativo, e possibilitando a criação de novos "desenhos venosos"*. Nesse sentido, posso afirmar-Ihe que as formas assumidas pelo meu hemangioma podem ser consideradas extremamente efêmeras e manipuláveis visto que, quando o seu trajeto sanguíneo sofre interferências externas e/ou internas" ${ }^{72}$, tanto seus "desenhos sanguíneos"* quanto suas cores podem ser (des)construídas e (re)criadas.

\footnotetext{
${ }^{72}$ As interferências internas fazem menção às regressões espontâneas (involuções naturais) que podem ocorrer dependendo do tipo de hemangioma e em fases específicas ao longo do seu processo. Outra possibilidade de regressão do acometimento são os procedimentos invasivos utilizados em tratamentos médicos do hemangioma, tais como escleroterapia, dentre outros.
} 
Nas figuras 26, 27 e 28 encontramos as modificações dos "desenhos venosos"* e cores do hemangioma sofridas em decorrência de uma compressão leve de um dedo.

Figs. 26, 27 e 28- "Desenhos do hemangioma".
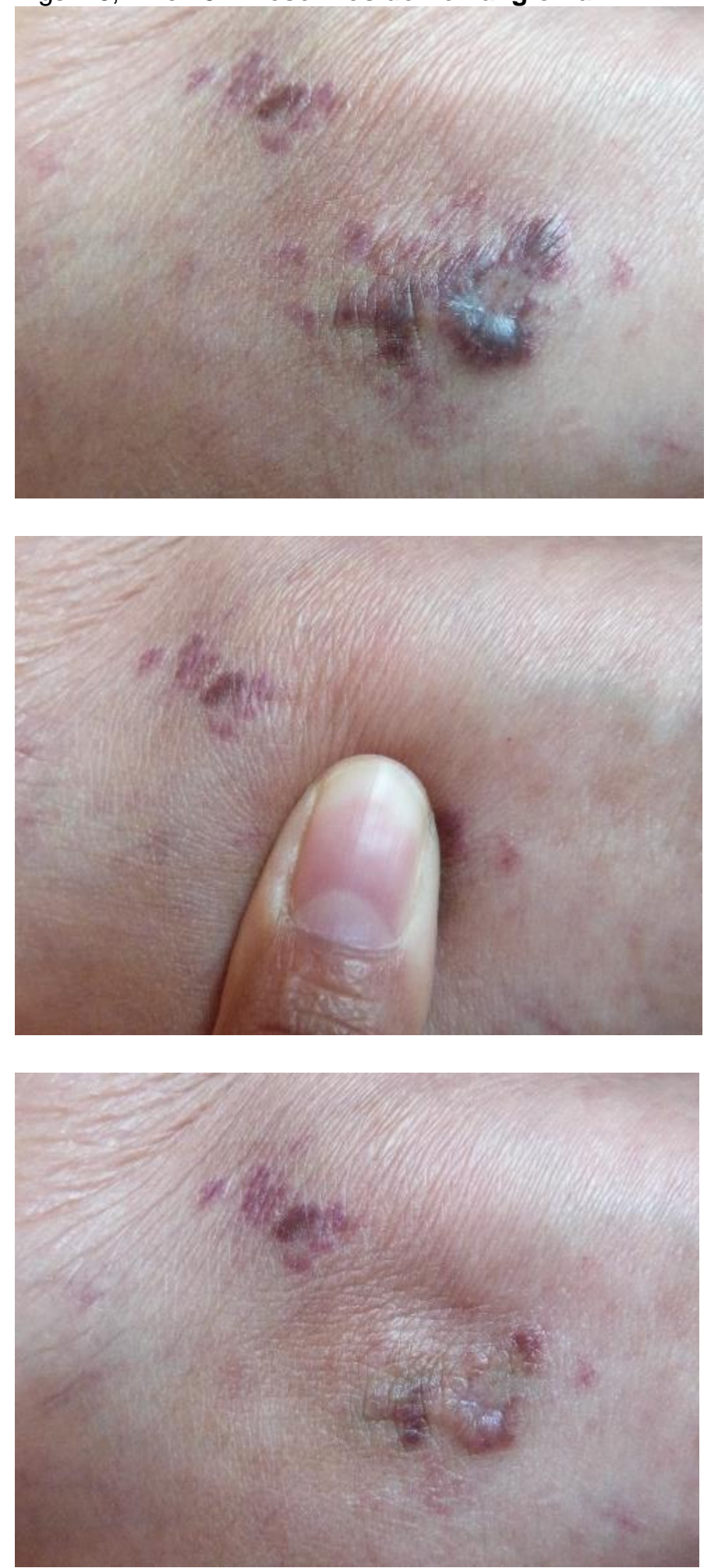

Foto: Tatiana Rodrigues. Local: Brasília, 18 set. 2014. 


\subsubsection{A poética das nuvens versus "desenhos venosos" *}

Em decorrência de uma complexa combinação de fatores atmosféricos na natureza, posso afirmar que as nuvens apresentam grande variedade de formas e características que the são únicas. Sendo assim, entendo que todas as combinações que interferem em seu processo formativo colaboram de maneira a determinar as suas inúmeras variantes, tais como: formatos, volumes, cores, iluminação, deslocamento nos céus, dentre outros.

Fig.29- Texturas do hemangioma.

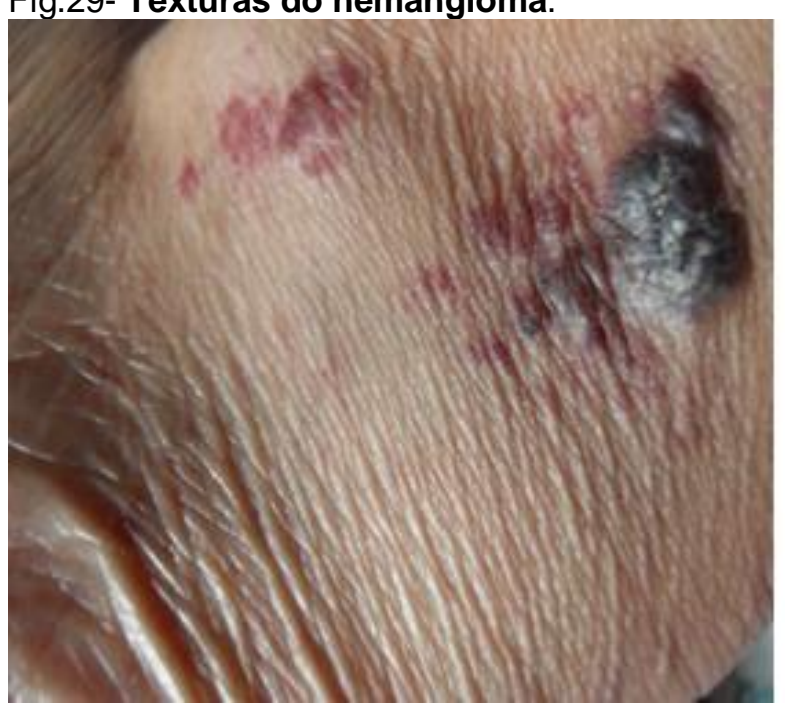

Foto: Tatiana Rodrigues

Local: Brasília, 07 jan. 2009.

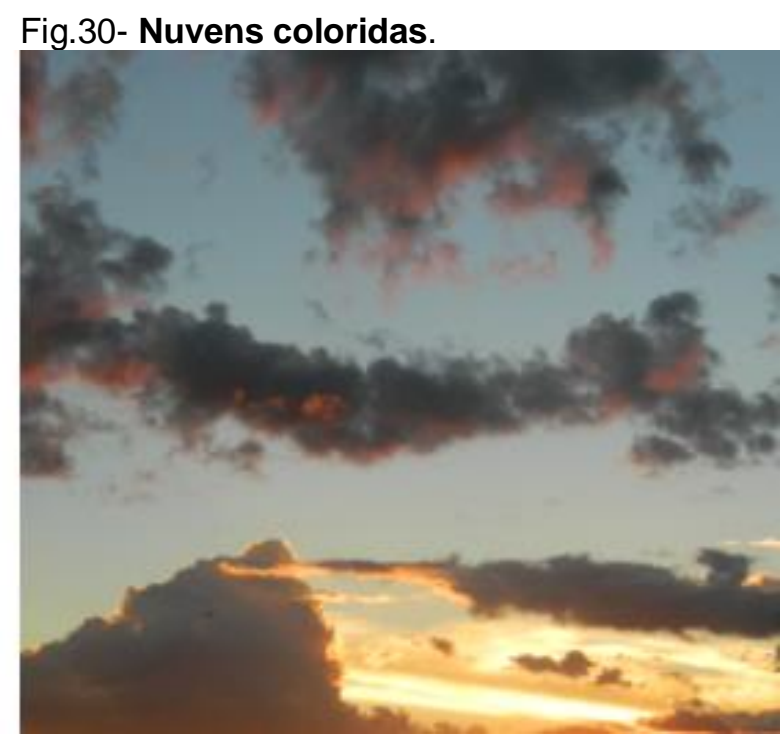

Foto: Tatiana Rodrigues Local: Brasília, 05 fev. 2014.

O processo lúdico presente no "jogo" de atribuir formas às nuvens nos céus apresenta um processo bastante semelhante com as percepções dos "desenhos venosos"* do hemangioma. No entanto, vale ressaltar que, em ambos os casos, o receptor torna-se um agente determinante nesse processo visto que ele atua sobre 0 conjunto dessas percepções. A primeira delas diz respeito ao próprio posicionamento do receptor em relação a esses objetos. Por exemplo, ao exercer uma ação direta (compressão) sobre o hemangioma de maneira a provocar-lhe alterações, um indivíduo jamais terá a mesma percepção e/ou abstração que um outro que apenas pode observá-lo à distância. O mesmo acontece com as diferentes percepções das nuvens obtidas por um indivíduo em um meio de transporte aéreo e outro que encontra-se em solo. 
Em uma análise mais profunda a respeito da atuação do receptor com relação às formas das nuvens e dos hemangiomas, enquanto objetos perceptíveis, observo que tais formas, também, ganham significação a partir do repertório de conhecimentos e interpretações de cada indivíduo. Essa linha de raciocínio fundamenta-se a partir da atuação do novo papel do receptor produzido pela Arte Moderna e descrito por Lucrécia D`Aléssio Ferrara (2005) em sua obra $A$ estratégia dos signos.

Segundo Ferrara (ibid.), a única maneira de permitir a apreensão da realidade em sua complexidade é provocar, pelo procedimento estético, a não identificação, a inadequação entre a linguagem e o seu referente. Tal afirmação complementa-se com o entendimento de que os automatismos perceptivos levam a uma simplificação da realidade pela imediata referência entre signo e objeto.

Nesse contexto, posso afirmar que o exercício de abstrair as formas das nuvens bem como dos hemangiomas possibilita que o receptor, utilizando-se do seu repertório de conhecimento individual, seja provocado a perceber, adentrar e interferir na complexa produção de sentido entre o signo e objeto. Para Ferrara (ibid.), forçar a atenção do observador é o objetivo que se propõe a arte modernista, e a "forma difícil" é a arma utilizada nessa captura. Sendo assim, percebo que, ao ser instigado pelas efemeridades de formas tanto das nuvens quanto dos hemangiomas, o receptor é levado a decifrar e atuar na realidade de maneira ativa, concedendo-lhe "formas" imbuídas de singularidades do seu repertório criativo.

\subsubsection{A poética do hemangioma-luz*: nascimento das macroimpressões artísti- cas}

As macroimpressões artísticas são a resultante da poética da criação do hemangioma-luz* ou macroimpressão-luz ${ }^{*}$ que surge a partir dos inúmeros processos de projeção de imagens em contínuo diálogo com a fotografia que segundo Dubois (2012) é uma curiosa questão de luz, ou melhor, de circulação de luz.

No processo criativo de "circulação de luz", as primeiras macroimpressõesluz ${ }^{*}$ absorvidas pela fotografia sobrepõem-se sobre a pele do corpo do outro, projetando e acomodando sobre ele suas variações de tonalidades de cores, formas, contornos; sua própria essência. Assim, a partir dessa nova configuração, o hemangiomaluz* apropria-se do tecido da pele do outro e projeta sobre ele suas impressões imagéticas; suas emanações de luz. As novas imagens, constituídas a partir de tais 
projeções de imagens, ao apropriar-se de novos elementos ao seu repertório, corporificam-se e originam não apenas novas construções imagéticas, mas acabam por conceber o nascimento-luz* de novas macroimpressões. Logo depois, essas novas macroimpressões são projetadas simultaneamente e fundidas em uma emanação de luz conjunta que dará origem às últimas macroimpressões-luz* que, mais uma vez, serão metamorfoseadas em macoimpressões-artísticas-luzes* pela alquimia fotográfica, segundo Dubois (2012).

Em uma tentativa de elucidação desse processo, posso afirmar que as primeiras macroimpressões artísticas nascidas pelo processo de "circulação de luz" que originaram as primeiras séries fotográficas, complementam-se pela utilização de um segundo processo-luz* ainda mais complexo a fim de compor a versão final das macroimpressões artísticas. O segundo processo-luz* é considerado complexo porque a última captura fotográfica é a resultante das projeções simultâneas de imagens, bem como da convergência de todo o potencial-luz* em circulação ao longo das etapas compositivas do processo.

De acordo com essa perspectiva, posso afirmar que as macroimpressões do hemangioma, conservadas por meio do hemangioma-luz*, parecem ter escrito, ou mesmo, entalhado ${ }^{73}$ por meio da ferramenta-luz* todas as macroimpressões artísticas propostas nesta pesquisa. Nesse contexto, a origem da última macroimpressão artística, corpos hemangescritos, pode ser entendida como o apogeu desse potencialluz* visto que seu nascimento-luz* se deve à convergência entre todas as construções-luzes* realizadas nas etapas compositivas ao longo do processo criativo.

Com base nesse entendimento, posso dizer que as macroimpressões artísticas foram consubstanciadas (com) e (pela) luz, visto que ela se fez necessária tanto ao surgimento das imagens quanto em todo o processo fotográfico. O corpo fotográfico nasce e morre na luz e pela luz (Dubois, 2012).

\footnotetext{
${ }^{73} \mathrm{O}$ termo entalhar significa fazer, em madeira ou outro material, entalhe ou talho de; gravar uma imagem. Entalhe é o corte, incisão, ranhura na madeira; entalha, entalhamento, entalhadura, entalho (p.ext.) esse mesmo tipo de corte feito em outros materiais (metal, cerâmica, vidro etc.) (Art. Plást.) Obra de arte em madeira, pedra etc.; talha. Fonte: Dicionário Eletrônico Houaiss da Língua Portuguesa 3.0.
} 


\subsection{Processo criativo das produções artísticas}

De uma maneira geral, o processo criativo das produções artísticas acontece da seguinte maneira: primeiramente, o uso da fotografia possibilita que o hemangioma seja "capturado" imageticamente. Em uma segunda etapa, os recursos fotográficos digitais e computacionais possibilitam o tratamento das imagens. Nesse contexto, ao utilizar os programas de computador Adobe Photoshop e Paint para tratamento da fotografia, novas delimitações do hemangioma vão sendo estabelecidas a partir das modificações nas cores de fundo incorporadas à imagem. Esse tratamento imagético tem por finalidade favorecer o diálogo da projeção das fotografias com a iluminação e/ ou composições das séries fotográficas trabalhadas em uma etapa posterior. É importante salientar que as modificações tonais decorrentes da transcodificação do corpo para a captura fotográfica e desta para o tratamento no software coexistem juntamente com as modificações advindas do processo de projeção.

Fig.31- Marcas de nascença 3.

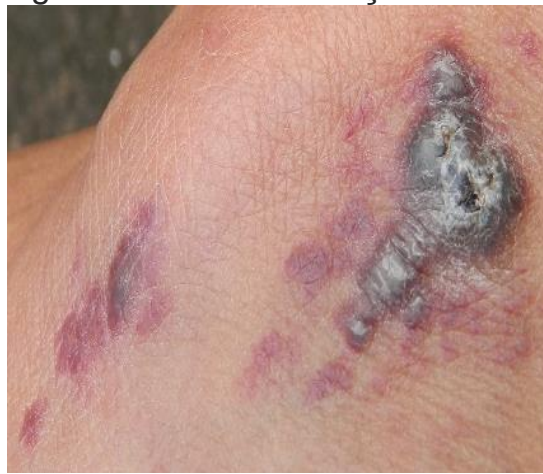

Foto: P. R. Freitas

Local: Brasília, 27 maio 2012.

Fig.34- Marcas de nascença 4.

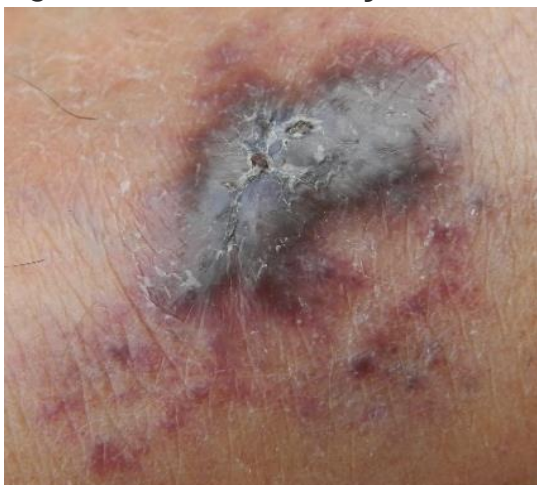

Foto: P.R. Freitas

Local: Brasília, 27 maio 2012.
Fig.32- Marcas de nascença 3.

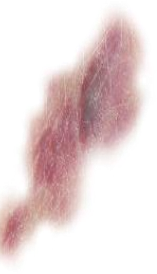

Edição: Alexandre Sá Prog. : Adobe Photoshop CS6 Local: Brasília, 18 dez. 2013.

Fig.35- Marcas de nascença 4.

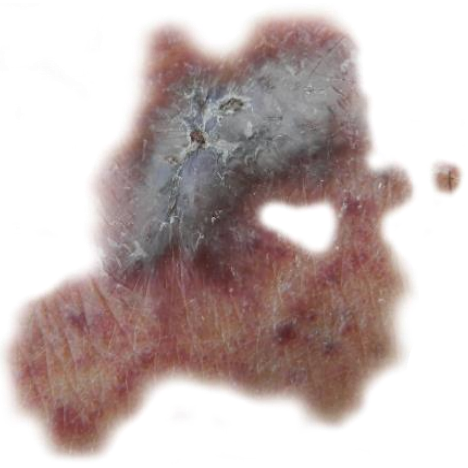

Edição: Alexandre Sá

Prog.: Adobe Photoshop CS6 Local: Brasília, 18 dez. 2013.
Fig.33- Marcas de nascença 3.

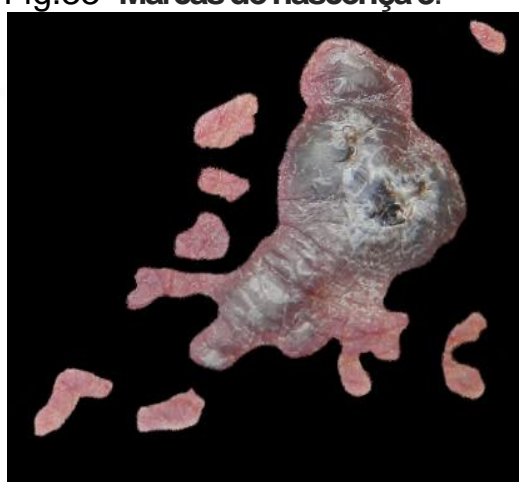

Edição: Tatiana Rodrigues

Programa: Paint

Local: Brasília, 04jan. 2014.

Fig.36- Marcas de nascença 4.

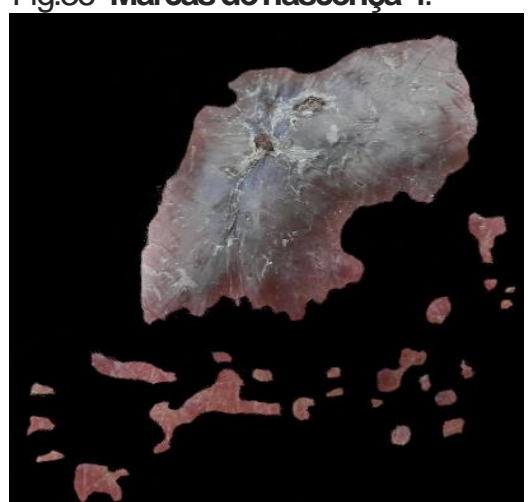

Edição: Tatiana Rodrigues

Programa: Paint

Local: Brasília, 04 jan. 2014. 
Fig. 37- Marcas de nascença 5.

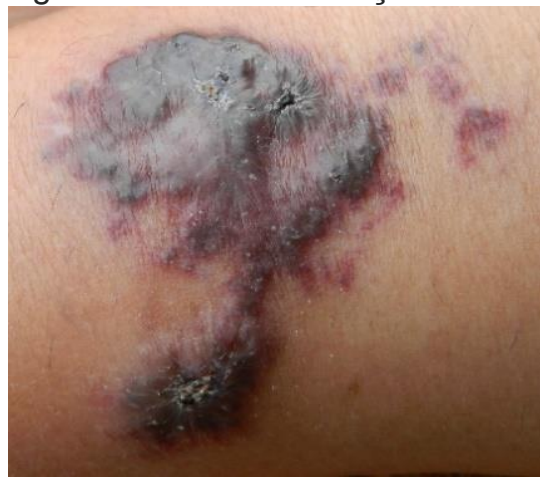

Foto: P.R. Freitas

Local: Brasília, 27 maio 2012.
Fig. 38- Marcas de nascença 5.

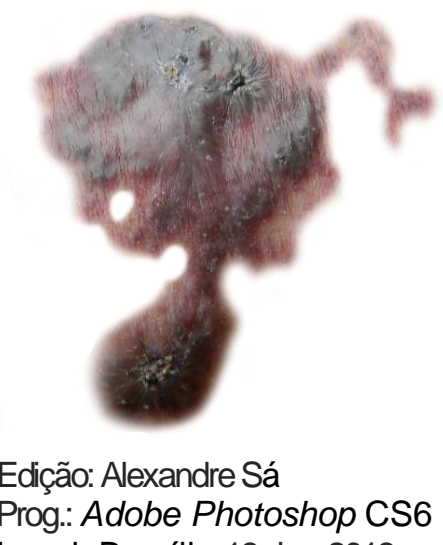

Fig. 39- Marcas de nascença 5.

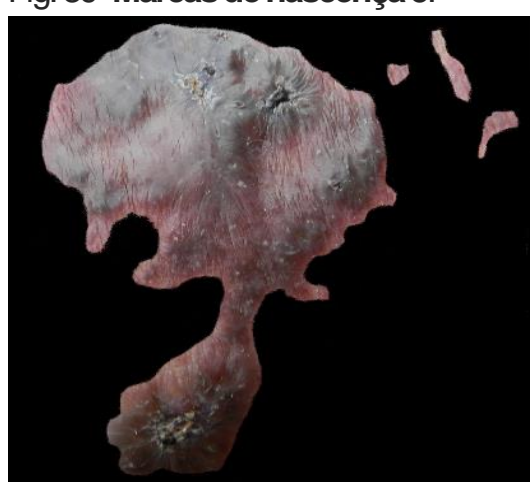

Edição: Tatiana Rodrigues

Programa: Paint

Local: Brasília, 04 jan. 2014.

Em uma terceira etapa, o recurso da projeção permite que o corpo-suporte vivencie, imageticamente, a "reprodução" das singularidades encontradas nas macroimpressões do corpo acometido pelo hemangioma. Vale ressaltar que as três variações da fotografia acima apresentadas foram utilizadas nas composições fotográficas. Nesse contexto, a projeção das imagens do hemangioma e o olhar do fotográfico, juntamente com os elementos compositivos e artísticos da cena, interagiram colaborativamente de maneira a possibilitar a criação das seguintes séries fotográficas: Fragmentos hemangescritos 1 e Fragmentos hemangescritos 2, Angioressonância hemangescrita e a Corporação hemangescrita. Logo adiante essas séries fotográficas serão apresentadas juntamente com as especificidades dos seus processos de produção.

A penúltima etapa trata-se da convergência entre as imagens das séries fotográficas citadas anteriormente por meio do uso da projeção. Nesse processo, as imagens selecionadas são projetadas simultaneamente de maneira que as primeiras macroimpressões são sobrepostas em várias "camadas", em uma espécie de fusão de imagens, originando assim novas macroimpressões artísticas: os corpos hemangescritos. Esse processo objetiva favorecer a interação, o diálogo e a metamorfose entre as macroimpressões por meio da projeção simultânea entre as primeiras construções artísticas (séries fotográficas).

O último procedimento refere-se ao registro fotográfico das macroimpressões artísticas nomeado corpos hemangescritos. Sendo assim, posso afirmar que a produção artística que integra o corpo, a fotografia, a projeção do hemangioma e a convergência entre as projeções de imagens, mediado e potencializado pelas possibilidades 
artísticas e tecnológicas, origina as macroimpressões artísticas propostas neste trabalho de pesquisa.

É importante destacar que o termo macroimpressão artística objetiva enfatizar o fato de que, diferentemente das macroimpressões naturais dos indivíduos, esta refere-se a um processo de (re)impressão e (re)criação poética a partir da concretização das etapas anteriormente narradas. Assim, concebida e mediada pelas concepções artísticas-tecnológicas, bem como pelo olhar do fotógrafo e artista, as macroimpressões artísticas buscam transcender sua efemeridade compositiva e eternizar-se imageticamente. Isso porque a produção fotográfica resultante da projeção de imagens traz um conteúdo extremamente perceptivo e com grande potencialidade criativa e interpretativa por parte do receptor. Dessa maneira, essa produção artística possibilita que o receptor venha a projetar um novo olhar rumo às macroimpressões.

\subsubsection{Projeção de imagens}

A projeção de imagens constitui um recurso tecnológico de grande importância na produção das obras artísticas desta pesquisa. Isso se deve ao fato de que esse recurso possibilita que a marca de nascença hemangioma, inicialmente capturada pela lente fotográfica, seja projetada em outros corpos.

O corpo como suporte das projeções do hemangioma possibilita a criação de novas construções imagéticas e/ou configurações e/ou possibilidades composicionais. Isso acontece porque, ao receber a imagem projetada do hemangioma, enquanto suporte, esse corpo compartilha seus elementos constitutivos, ou mesmo, suas macroimpressões que serão parte integrante dessa nova composição. Assim, entende-se que o corpo-suporte se apropriará, mesmo que momentaneamente, das macroimpressões do corpo do outro por meio da projeção do hemangioma-luz*.

Outro destaque quanto ao uso da projeção refere-se às projeções simultâneas que darão origem as novas macroimpressões artísticas: os corpos hemangescritos. Essa convergência de projeções possibilita que as primeiras marcas do hemangioma-luz* sejam perpetuadas, apesar das metamorfoses-luz* ocorridas ao longo do processo-luz* composicional. Sendo assim, entende-se que a utilização da 
projeção de imagens aliada às potencialidades da fotografia tornam-se os mediadores desse processo de construção artística.

\subsection{Apresentação das séries fotográficas: macroimpressões artísticas}

\subsubsection{Produção: Fragmentos hemangescritos 1}

A série fotográfica fragmentos hemangescritos 1 trata de uma produção artística obtida a partir da projeção da fotografia do hemangioma (Cf. figs.32,35 e 38: fundo branco) no corpo de um indivíduo não acometido pela marca.

Figs. 40, 41, 42 e 43 - Série fotográfica: Fragmentos hemangescritos 1.
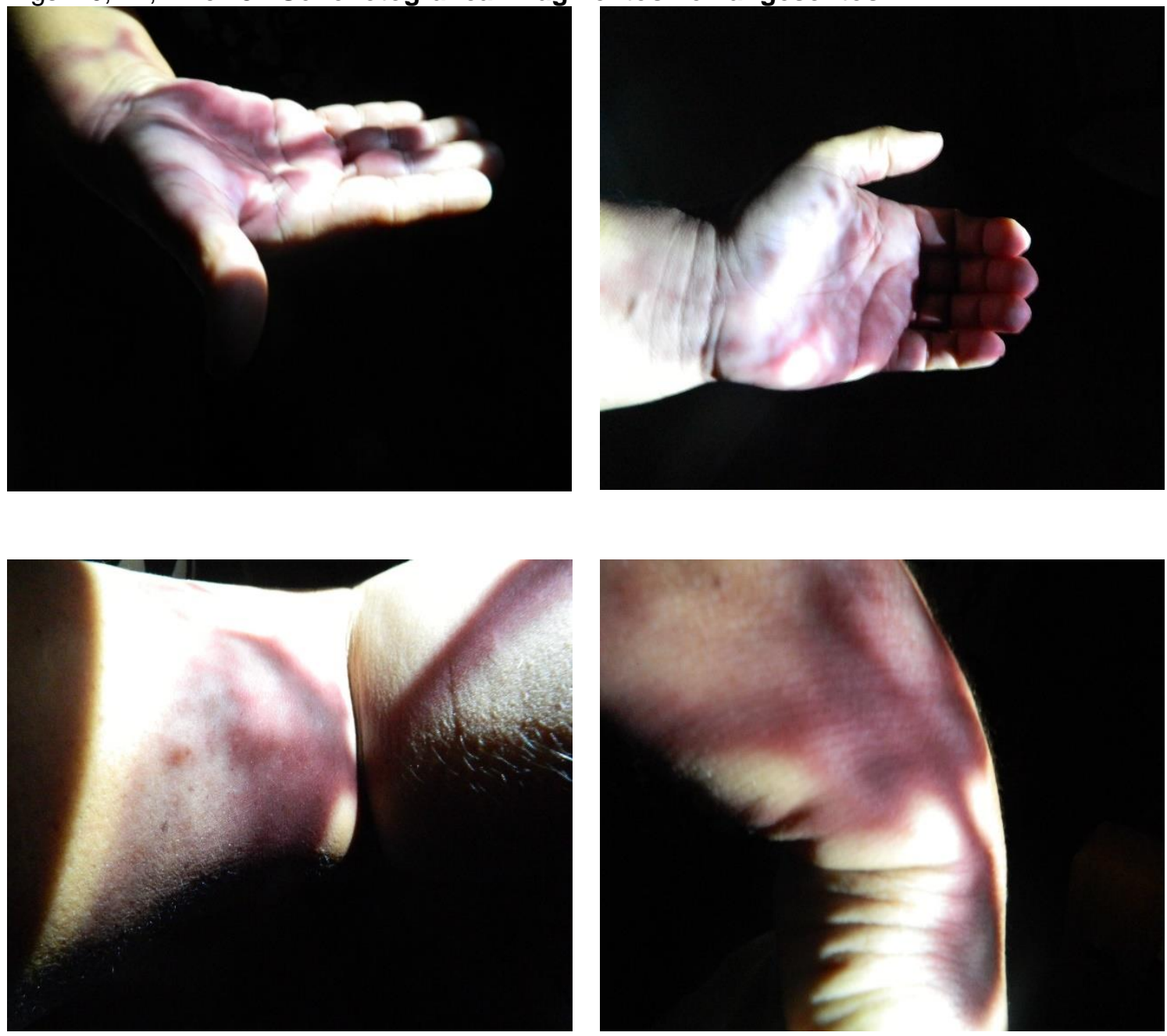

Foto: Tatiana Rodrigues. Local: Brasília,11 fev. 2014. Série de 160 fotografias. 
Figs. 44, 45, 46 e 47- Série fotográfica: Fragmentos hemangescritos 1.
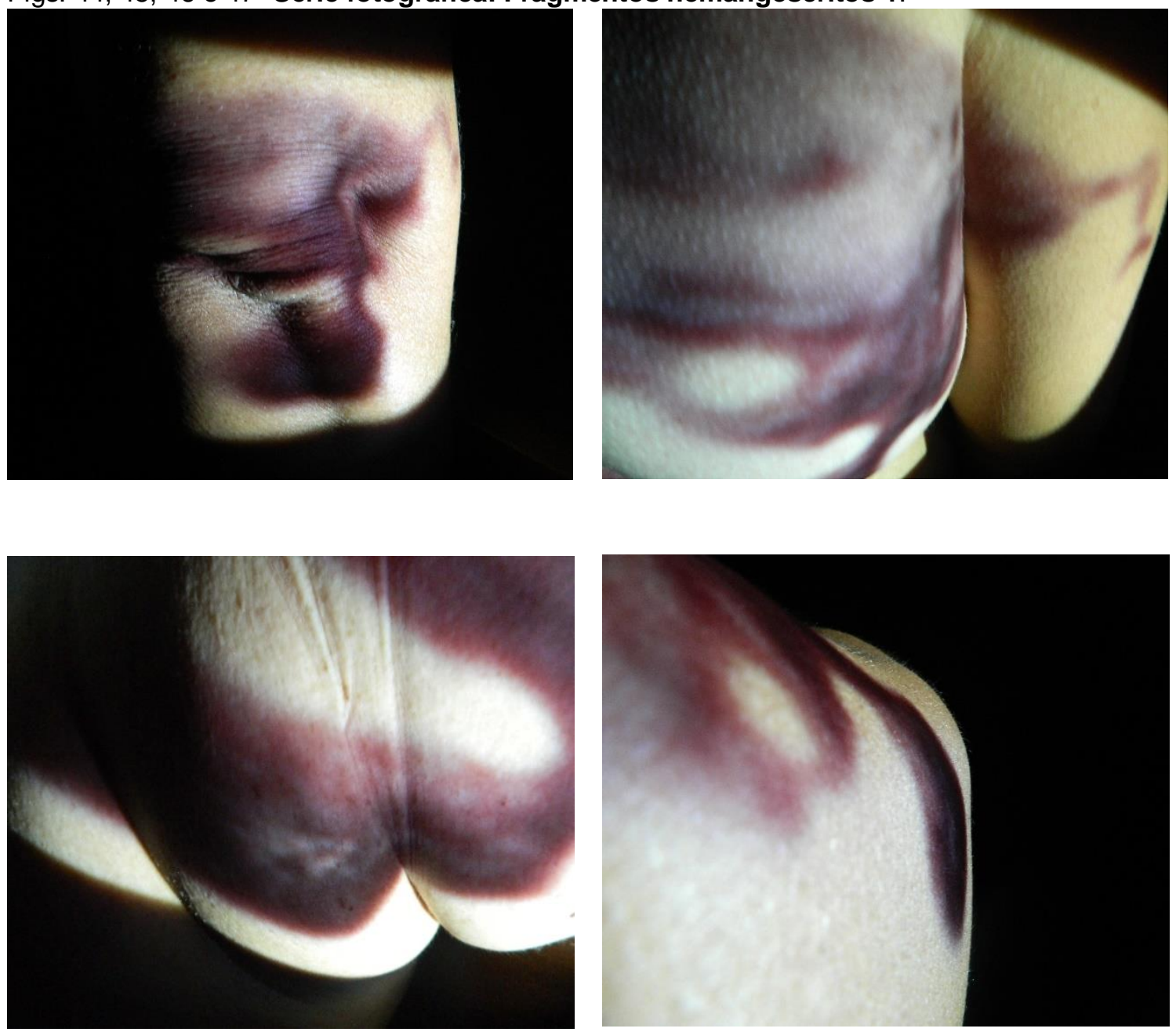

Foto: Tatiana Rodrigues. Local: Brasília,11 fev. 2014. Série de 160 fotografias.

A escolha pelos enquadramentos fotográficos com o enfoque na projeção do hemangioma em determinadas partes dos corpos busca desenvolver artisticamente o conceito de Jeudy (2002) a respeito do corpo estranho abordado no estudo teórico. Segundo as definições do autor:

O corpo estranho se presta a todas as fantasias que suscitam a atração ou a repulsão. Ele pode ser idealizado como a expressão de uma beleza inacessível e/ou rejeitado como o símbolo que objetiva os sinais da repulsa. Provocando de uma maneira imaginária a possível vertigem da mais radical alteridade, ele cristaliza as frustações e, simultaneamente possibilita a aventura misteriosa dos sentidos. (JEUDY, 2002, p. 102). 
A partir de tais conceituações, entendo que esse "corpo estranho", que é capaz de provocar sentimentos tão ambíguos no outro, com a mesma intensidade, parece despertar-Ihe o desejo de lançar seu olhar esmiuçador rumo ao desconhecido em uma verdadeira "aventura misteriosa dos sentidos". Em conformidade com esse propósito, o olhar do Outro captura esse "fragmento de corpo", onde repousa a estranheza com seu melhor enquadramento, zoom, angulação e/ou nitidez no intuito de desvendar-lhe o mistério.

Desse modo, a proposta de iluminação dessa série fotográfica foi elaborada com o propósito de desenvolver, artisticamente, esse conceito, surgindo, assim, a ideia do holofote ${ }^{74}$ de luz. Isso porque esse tipo de recurso de iluminação possibilita que o objeto e/ ou sujeito seja iluminado de maneira direcionada, e se torne o ponto central da composição. Em harmonia com essa proposta, as luzes do ambiente fotográfico foram desligadas a fim de que o escurecimento no fundo fotográfico pudesse destacar o foco de iluminação. Nesse contexto, o uso do mini projetor (figs. 48, 49 e 50) no papel do holofote de luz possibilitou que os fragmentos dos corpos com a projeção do hemangioma se tornassem o enfoque principal da captação fotográfica, e "simulassem" o enfoque do olhar do Outro. Ressalto, ainda, que os recursos fotográficos utilizados para o enquadramento das imagens foram obtidos por meio do zoom e da escolha dos ângulos e distanciamento entre a câmera e o objeto fotografado.

Figs.48, 49 e 50- Mini projetor MPro110 3M.
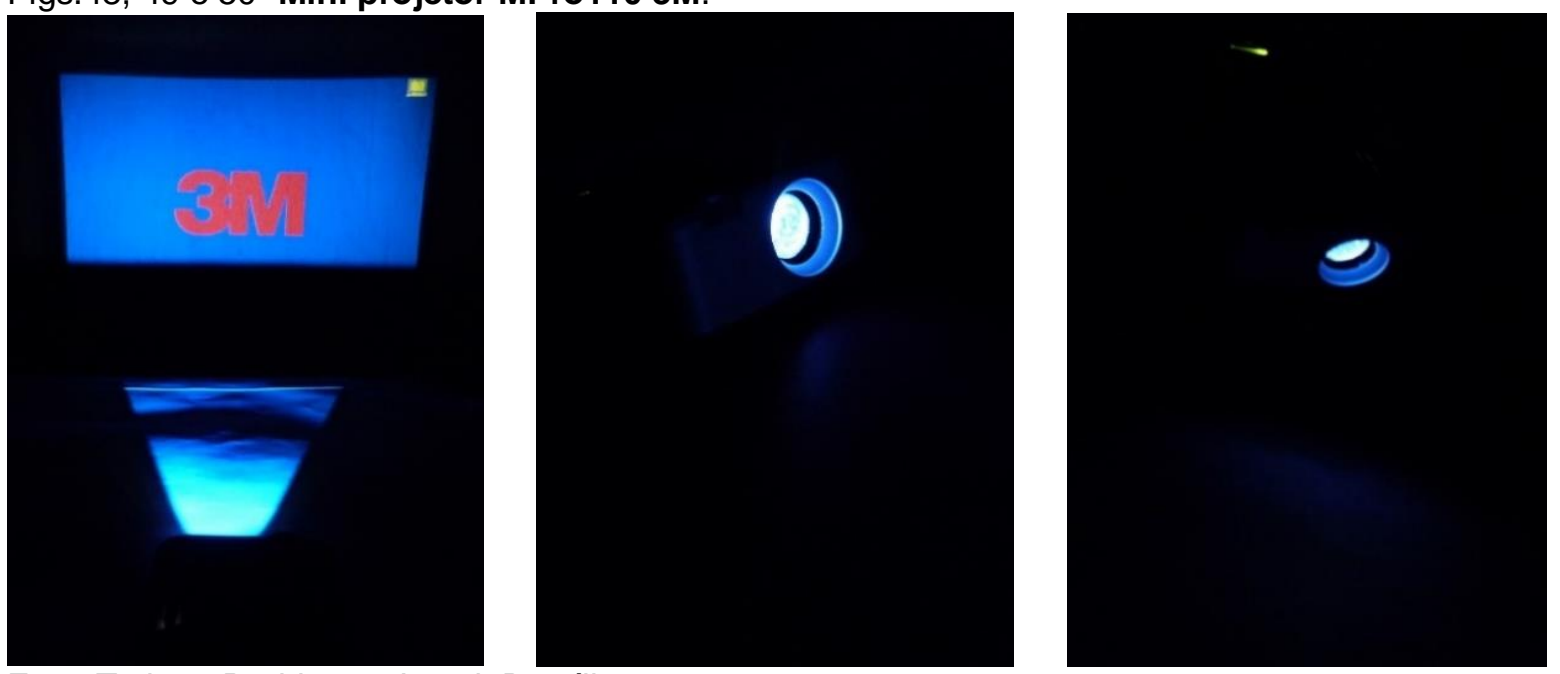

Foto: Tatiana Rodrigues. Local: Brasília, 12 set. 2014.

${ }^{74}$ Aparelho que projeta intenso facho de luz, esp. Us. Para iluminar objetos a distância. Fonte: Dicionário Eletrônico Houaiss da Língua Portuguesa 3.0. 
Em condições normais, a luz do projetor traria uma claridade incompatível com essa proposta de composição. Entretanto, o equipamento utilizado possui tamanho micro, modelo MPro110 3M. Essa especificação do aparelho possibilitou que o tamanho da imagem, 11,9 mm (0,47"), reduzisse drasticamente as áreas de iluminação da projeção. Isso pode ser melhor compreendido ao mensurarmos o tamanho total que a imagem em diagonal pode alcançar, entre 150 até $1270 \mathrm{~mm}$ (6"-50"). A partir dessa informação, percebe-se que, mesmo com a utilização do tamanho máximo da imagem, quando projetado em um ambiente sem iluminação, o mini projetor parece exercer o papel de um mini holofote de luz ao projetar seu foco de luz rumo às partes do corpo a serem fotografadas.

\subsubsection{Poética: Fragmentos hemangescritos 1}

Projetar o hemangioma em outros corpos significa partilhar minhas macroimpressões-luz ${ }^{*}$ com outros indivíduos. As marcas que foram entretecidas juntamente com a formação do meu corpo, por meio do recurso da projeção, podem ser "abrigadas" em um corpo que desconhece o que é pertencer-lhes.

As gradações roxeadas do hemangioma-luz* projetam-se rumo a uma nova pele com poros, pelos, sinais, dobras, curvas, extremidades, cores, texturas, volumes, formas e recortes, incorporando-se as suas novas delimitações. Estas, permeadas pelo claro-escuro compositivo, derramam-se sobre a cútis do corpo suporte, esboçando suas imagens abstratas de grande potencial interpretativo que são capturadas pela fotografia.

Figs 51, 52 e 53- Série fotográfica: Fragmentos hemangescritos 1.

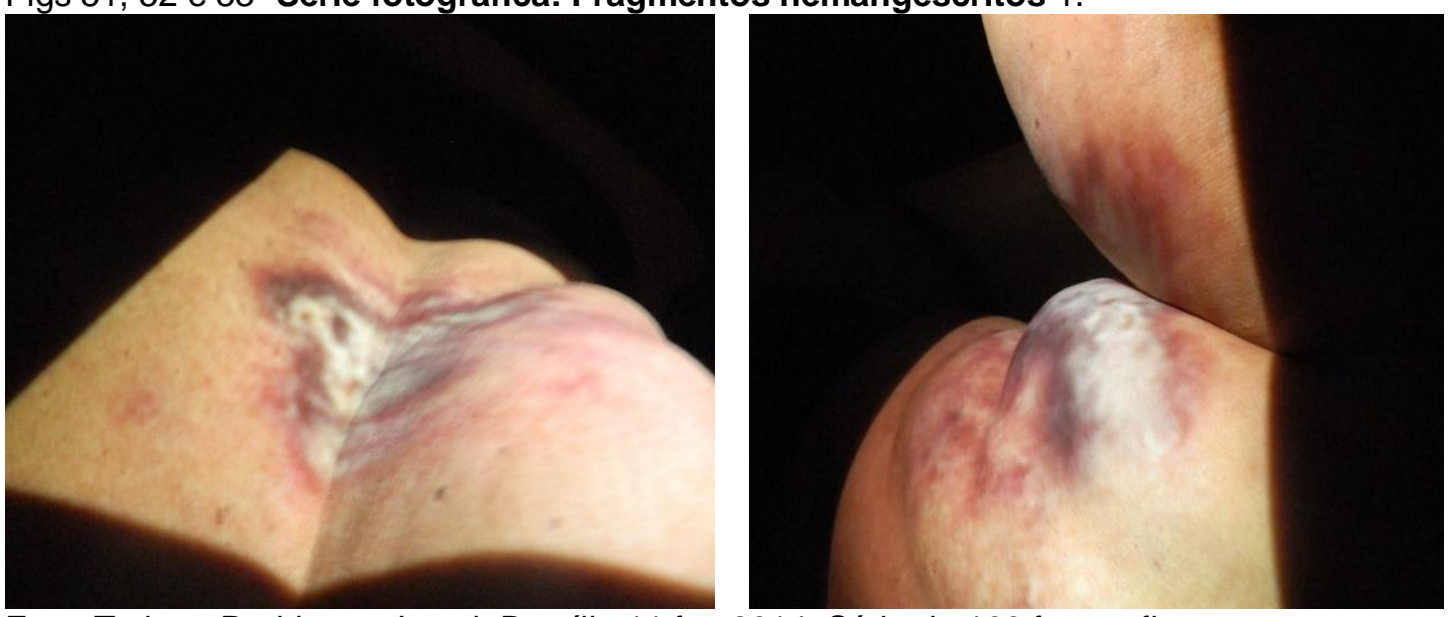

Foto: Tatiana Rodrigues. Local: Brasília,11 fev.2014. Série de 160 fotografias. 
Ao serem incorporadas pelo meu hemangioma-luz*, as macroimpressões do corpo-suporte fundem-se com a projeção, criando novas macroimpressões que possibilitam que esse indivíduo vivencie tanto as singularidades-luz* do acometimento em meu corpo quanto o resultado da interação entre essas macroimpressões.

A poética desta série fotográfica instiga 0 receptor a capturar 0 enquadramento das incertezas nos quais os fragmentos corporais buscam libertar o repertório criativo desses indivíduos a fim de que eles possam atribuir-lhes (re)impressões e/ou (re)significações.

\subsubsection{Produção: Fragmentos hemangescritos 2}

A série fotográfica fragmentos hemagescritos 2 surge a partir de um processo de troca no qual a internet torna-se seu principal mediador visto que ela disponibiliza o recurso do compartilhamento de dados entre diferentes usuários e/ou países essenciais a essa construção artística.

Sendo assim, a primeira etapa desse processo colaborativo consistiu no envio, via internet, das fotos dos meus hemangiomas (figs.31-39) a fim de que estes pudessem ser abrigados por meio da projeção em novos corpos suporte e em outra localidade territorial.

Em um segundo momento, acolhido na cidade de Londres, Inglaterra, meu hemangioma-luz ${ }^{*}$ foi permeado pelas novas roupagens compositivas advindas da acomodação nos novos corpos-suporte e pelo olhar dos colaboradores. Cientes que deveriam apenas projetar as imagens dos hemangiomas em seus corpos e depois fotografá-los, eles realizaram todo o processo de projeção, criação e/ou composição e captura fotográfica dessa série. As projeções do hemangioma-luz* foram realizadas pelos colaboradores de maneira a capturar toda a composição da cena, bem como a totalidade dos corpos envolvidos.

Na penúltima etapa, a série fotográfica foi enviada via internet sem edição. Os colaboradores me designaram a tarefa de submeter as fotografias a uma última etapa de edição, censura e/ou recorte e/ou seleção das imagens. Assim, diferentemente da primeira série apresentada, os enfoques fotográficos não foram obtidos apenas pelo olhar do fotógrafo, mas, também, por um processo de edição pós-fotográfica. 
Fig.54- Série Fotográfica: Fragmentos Hemangescritos 2.

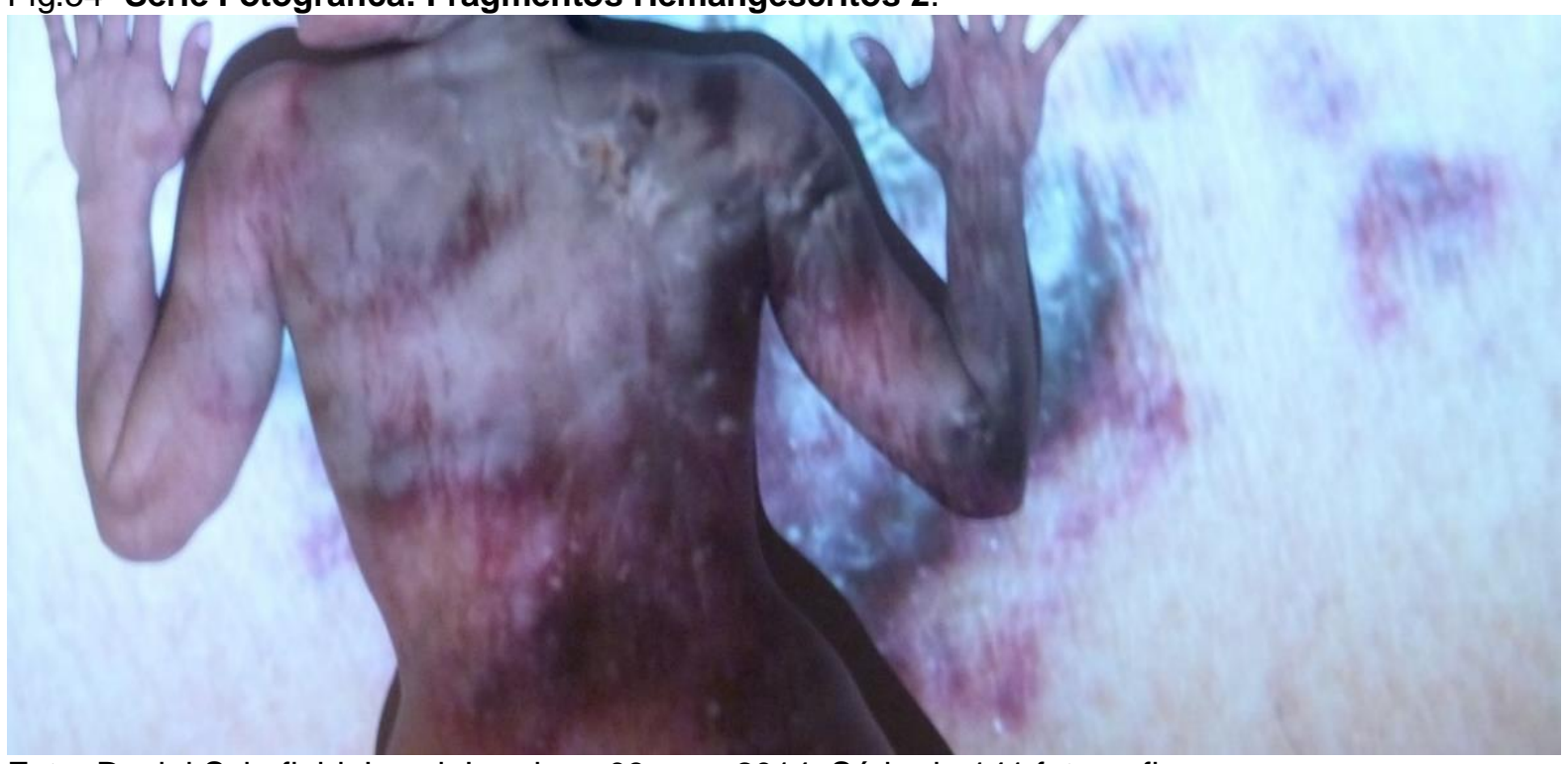

Foto: Daniel Schofield. Local: Londres, 09 mar. 2014. Série de 141 fotografias. Edição: Tatiana Rodrigues.

Fig.55 - Série Fotográfica: Fragmentos Hemangescritos 2.

Foto: Daniel Schofield. Local: Londres, 09 mar. 2014. Série de 141 fotografias. Edição: Tatiana Rodrigues.

Segundo os colaboradores, a iluminação da composição da cena contou com o uso dos seguintes elementos: as luzes de teto do ambiente, os abajures lateralizados e o foco de luz do projetor de imagens.

$\mathrm{Na}$ figura 56, temos o projetor utilizado pelos colaboradores nesta série fotográfica. 


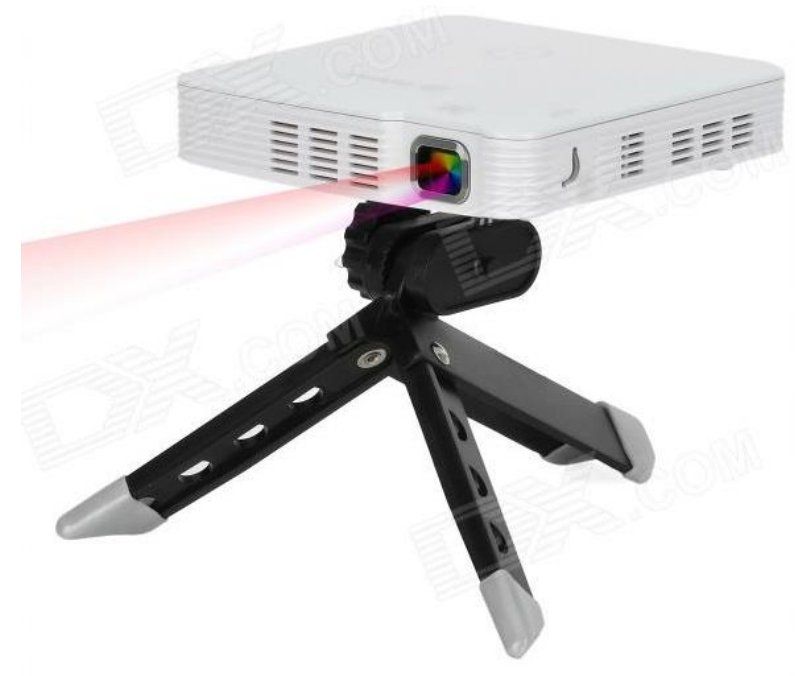

O tratamento de luz escolhido pelos colaboradores que resulta, muitas vezes, em uma ampla claridade do ambiente permitiu que as cores do hemangioma-luz ${ }^{*}$, bem como as texturas-luz, obtivessem grande destaque na captação imagética.

A movimentação do corpo-suporte capturada pela fotografia, assim como a sombra que emana desse corpo, resultou em variantes composicionais de grande potencialidade interpretativa. $O$ hemangioma-luz* parece incorporar as macroimpressões do corpo-suporte de maneira a criar, por meio da interação entre os elementos, novas possibilidades composicionais artísticas.

Outro fator de grande importância na composição fotográfica trata-se do trabalho de angulação, distanciamento e tamanho da projeção. A combinação destes elementos parece ter influenciado diretamente nas cores, criação de sombras e proporção das imagens projetadas, trazendo, assim, a sensação de agigantamento do hemangioma-luz*.

A proporção de grandeza trabalhada por meio da projeção de imagens parece reforçar a ideia metonímica da pessoa pela marca desenvolvida ao longo da pesquisa. Isso porque, muitas vezes, a marca de nascença incorpora-se e agiganta-se de tal maneira à imagem de um certo indivíduo que aquela dada marca passa a representar o próprio indivíduo acometido. Nesse sentido, a marca passa a referenciar a imagem daquela pessoa. A marca torna-se o próprio indivíduo.

${ }^{75}$ Disponível em: <http://www.dx.com/p/telstar-mp50-mini-projector-w-hdmi-for-iphone-samsung-htcwhite-172789\#> Acesso:13 agosto 2014. 23:18:20. 
No entanto, acredito que o grande diferencial nesta produção não deve-se apenas ao fato de eu ter compartilhado minhas marcas com outros corpos, mas a possibilidade da atuação do "olhar do Outro" no processo composicional ter me instigado a ver minha marca de nascença de modo diferente. E nesse sentido, posso dizer que não apenas pesquisei sobre as abordagens de Jeudy (2002) a respeito do importante papel que o olhar do Outro desempenha em instigar-nos a nos enxergar de modo distinto, mas pude vivenciar tal experiência.

\subsubsection{Poética: Fragmentos hemangescritos 2}

Nesta série fotográfica, minhas "aglomerações venosas hemangescritas"* ganham vida nos tecidos da pele de novos suportes corporais. Corpos que, apesar de distantes fisicamente, ao compartirem suas macroimpressões com o meu hemangioma-luz*, convergem-se em um só corpo-luz*.

\section{Fig.57- Série Fotográfica: Fragmentos Hemangescritos 2.}

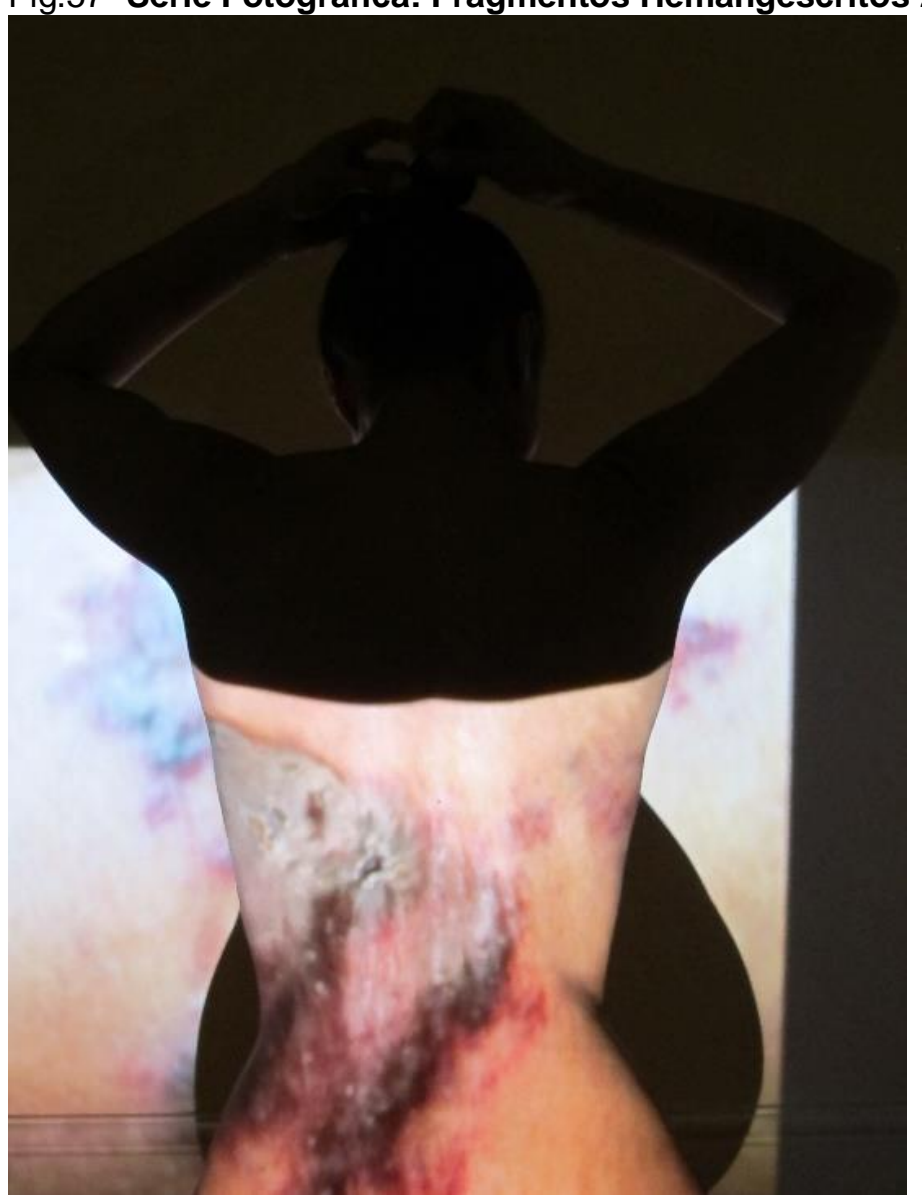

Foto: Daniel Schofield. Local: Londres, 09 mar. 2014.

Série de 141 fotografias. Edição:Tatiana Rodrigues. 
Figs.58 e 59- Série Fotográfica: Fragmentos Hemangescritos 2.
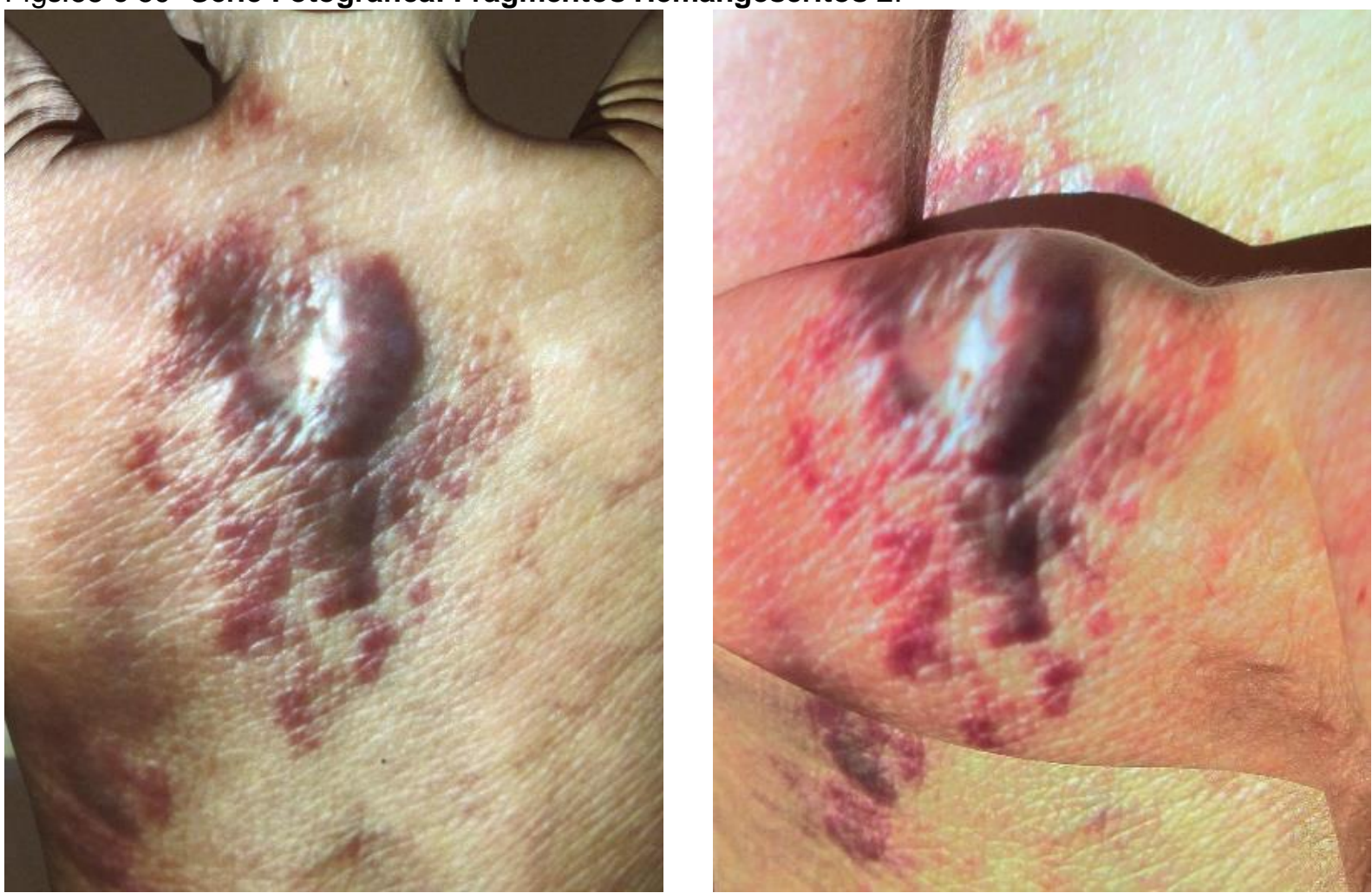

Foto: Juliana Rodrigues. Local: Londres, 09 mar. 2014. Série de 141 fotografias.

Edição:Tatiana Rodrigues.

Ao fragmentar a série fotográfica por meio do uso da ferramenta "corte", novas formas imagéticas pareciam tomar corpo. Era como se, sob o crivo do meu olhar, as fotografias estivessem sendo (re)modeladas visto que tais recortes definiam o que ia sendo revelado ou ocultado. Nesse sentido, tais imagens pareciam trabalhar com a interação compositiva. Isso porque a ausência de certos fragmentos de imagens reforçava a necessidade da presença de outras partes fundamentais à composição que, por fim, resultava na criação de novas imagens.

A mediação do "olhar fotográfico" dos colaboradores impregna novas perspectivas compositivas e agiganta os aspectos inusitados de minha marca. "Vestido" por outros corpos, meu hemangioma-luz* parece libertar a percepção do sensível emanada na composição-luz ${ }^{*}$ resultante da fusão entre as almas. Enxergarme, poeticamente, tanto no corpo feminino quanto no masculino parece libertar meu "olhar interior" frente ao sentir tais fotografias. 
Fig.60- Série Fotográfica: Fragmentos Hemangescritos 2.

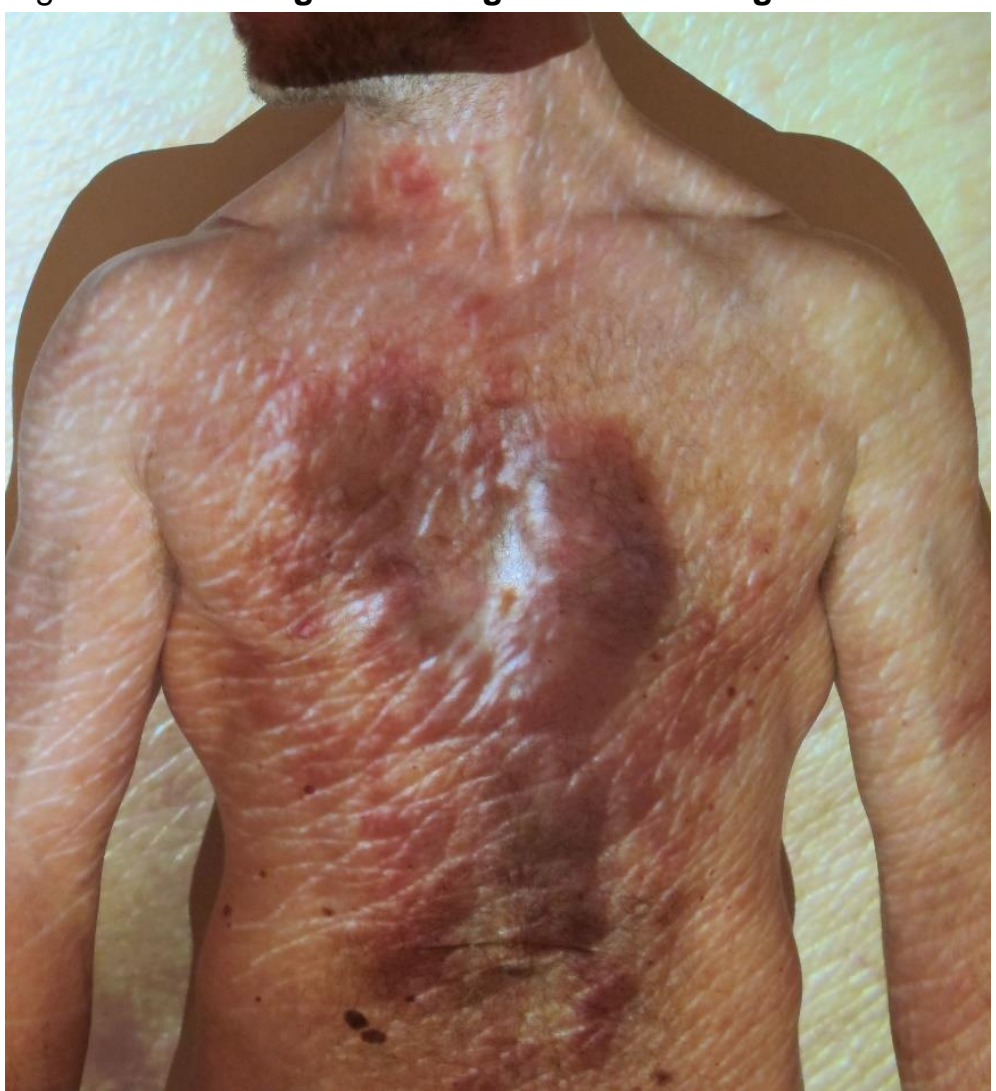

Foto: Juliana Rodrigues. Local: Londres, 09 mar. 2014.

Série de 141 fotografias. Edição:Tatiana Rodrigues.

De acordo com Barthes (1984), todos nós possuímos uma tábua interior de gostos, desgostos e indiferenças que influencia e que nos leva a compreender o interesse pela fotografia. No seguinte trecho, o autor exterioriza seu interesse pela fotografia por sentimento, trazendo-nos pistas sobre o sentir na fotografia: "[..] eu queria aprofundá-la, não como uma questão (um tema), mas como uma ferida: vejo, sinto, portanto, noto, olho e penso". (ibid., p.39).

\subsubsection{Produção: Angioressonância hemangescrita}

A série fotográfica angioressonância hemangescrita foi produzida a partir da projeção da imagem digitalizada do exame angioressonância (fig.61) da minha perna esquerda em um corpo-suporte. 
Fig.61- Angioressonância da perna esquerda.

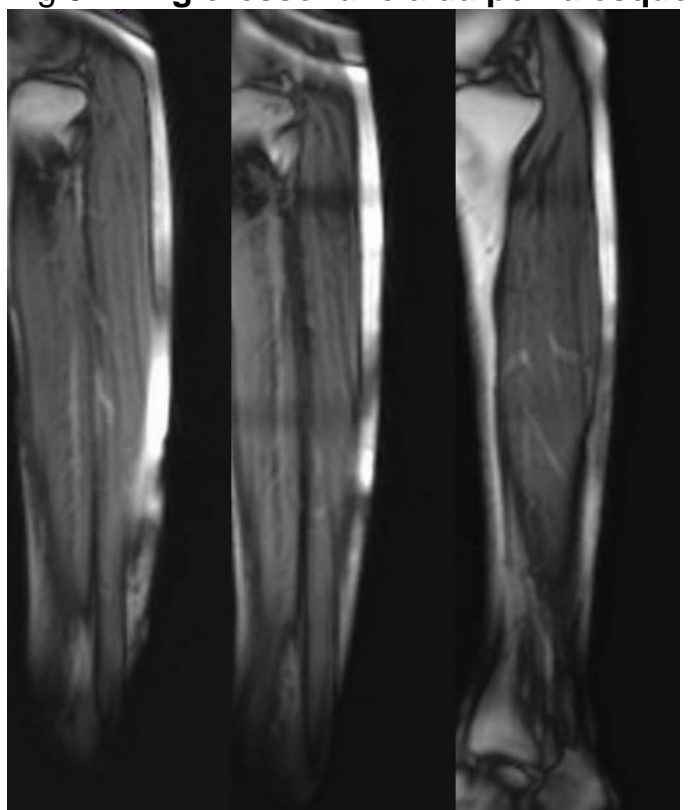

Imagem: Clínica DAPI- Diagnóstico Avançado por Imagens. Local: Curitiba, 01 set. 2012.

A referida projeção foi executada com as luzes apagadas a fim de que a ambientação escura pudesse dialogar com o fundo preto da angioressonância e favorecer o seu contraste entre o claro-escuro. O uso do mini projetor (Cf. figs.48, 49 e 50) atuou como um foco de luz cuja intensidade foi regulada por meio da espécie de gelatina ${ }^{76}$ criada pela angioressonância que, também, resultou em efeitos cromáticos na composição das imagens.

Esta série fotográfica foi concebida a partir da ideia de Zamboni (2006) de que a arte não contradiz a ciência; ela apenas utiliza-se de meios que nos leva à compressão de certos aspectos de maneira que a ciência não se permite fazer. Dentre as várias concepções trabalhadas em sua obra A pesquisa em Arte, Zamboni (ibid.) explicita nesse trecho que o que acontece na relação entre Arte e Ciência é que existem formas de pensamentos que habitualmente se relacionam ao tipo de atividade utilizada em arte e outras com as atividades de ciência. Uma das diferenças que o autor pontua entre essas formas se deve ao fato de que a explicação na ciência volta-se para um caráter geral. Ou seja, a ciência busca leis que sirvam para generalizações e poderão ser aplicadas em outras realidades. Já a explicação artística é extremamente particular, embora sua transmissão de mensagens seja bastante ampla.

\footnotetext{
${ }^{76}$ FOT TEAT. Folha translúcida colorida (ger. de celofane) que, colocada sobre refletores, produz efei-
} tos cromáticos na iluminação. Fonte: Dicionário Eletrônico Houaiss da Língua Portuguesa 3.0. 
Sendo assim, a criação artística desta série fotográfica foi elaborada em conformidade com os seguintes procedimentos: primeiro, incorporei o uso do recurso investigativo imagético da ciência médica na produção artística de maneira que estas imagens pudessem ser (re)criadas em um outro corpo; depois, projetei em um corposuporte as imagens disponíveis em CD da minha angioressonância, exame de ressonância ${ }^{77}$ dos vasos sanguíneos, que havia realizado em perna esquerda para fins de diagnóstico do hemangioma.

\section{Fig.62- Série Fotográfica: Angioressonância Hemangescrita.}

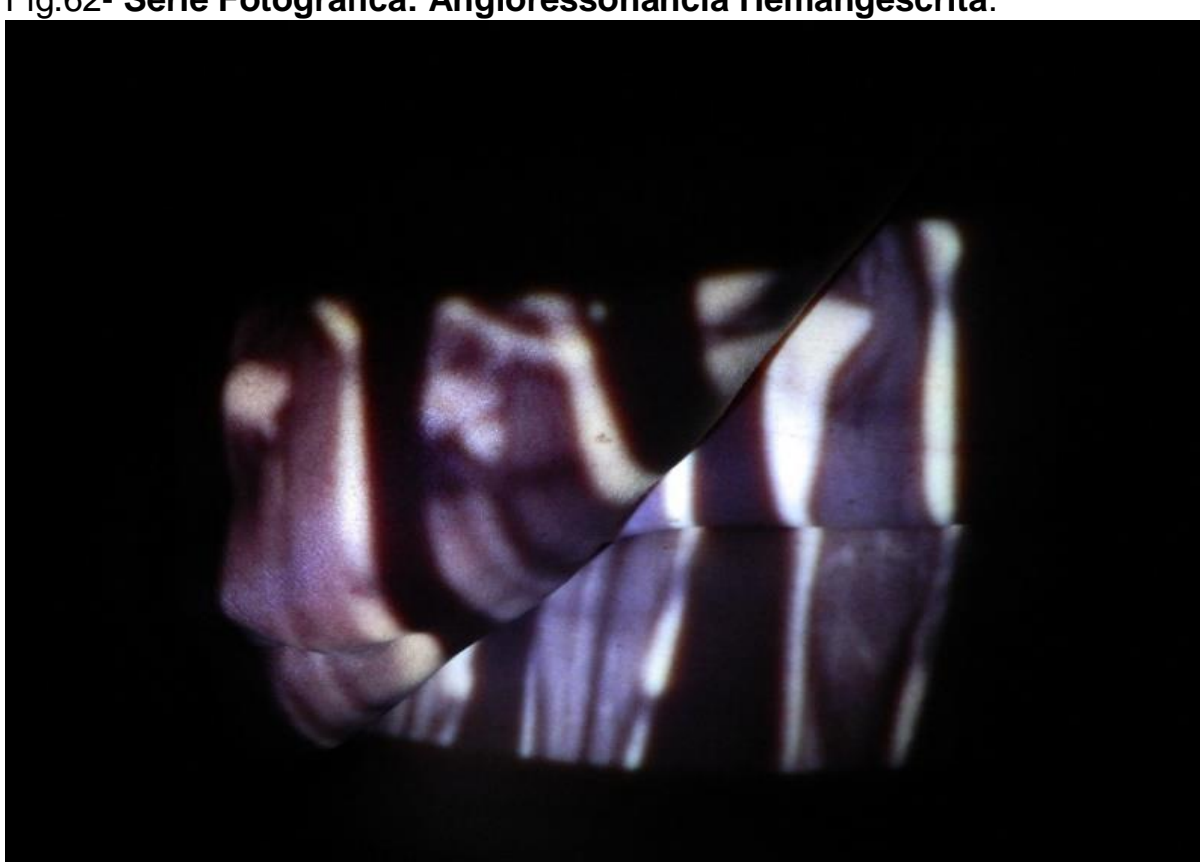

Foto: Tatiana Rodrigues. Local: Brasília, 20 fev. 2014. Série de 58 fotografias.

A proposta de uso da angioressonância objetivou incorporar esse método científico, de caráter geral, a um processo artístico criativo de cunho extremamente particular, mas com transmissão de mensagem generalista. Tal fato pode ser comprovado porque, por meio do meu olhar poético, utilizei dos recursos fotográficos em busca de uma composição que integrasse o recurso científico a sua "paleta compositiva"*. Assim, entendo que o diálogo entre os recursos próprios a cada uma dessas linguagens reafirma a possibilidade de convergência do poder criativo entre elas.

${ }^{77}$ R. Magnética Nuclear MED.NUC QUÍM fenômeno físico de orientação de certos núcleos atômicos sob o efeito de um campo magnético intenso, us. em análise química, em medicina com fins diagnósticos etc. [sigla: $R M M$ ]. Fonte: Dicionário Eletrônico Houaiss da Língua Portuguesa 3.0. 


\subsubsection{Poética: Angioressonância hemangescrita}

As deformidades capturadas nestas imagens parecem emergir de um grande "campo escuro" 78 que liberta os mais enigmáticos "desenhos"* esboçados pela angioressonância-luz*. Os efeitos cromáticos concebidos pela angioressonância irradia as sutilezas de tons que, aderidos à pele-luz*, revelam as ramificações sanguíneas que afluem rumo à formação venosa do hemangioma.

As imagens interiores do membro perna projeta suas sombras e/ou luzes criativas sobre a pele cuja escuridão engole a inteireza do corpo suporte. A captura delimitativa dos ossos e músculos absorvidos pela angioressonância parece tatuar seus pigmentos-luz* sobre as macroimpressões que recobrem o corpo sobre o qual repousa as projeções.

Fig.63- Série Fotográfica: Angioressonância Hemangescrita.

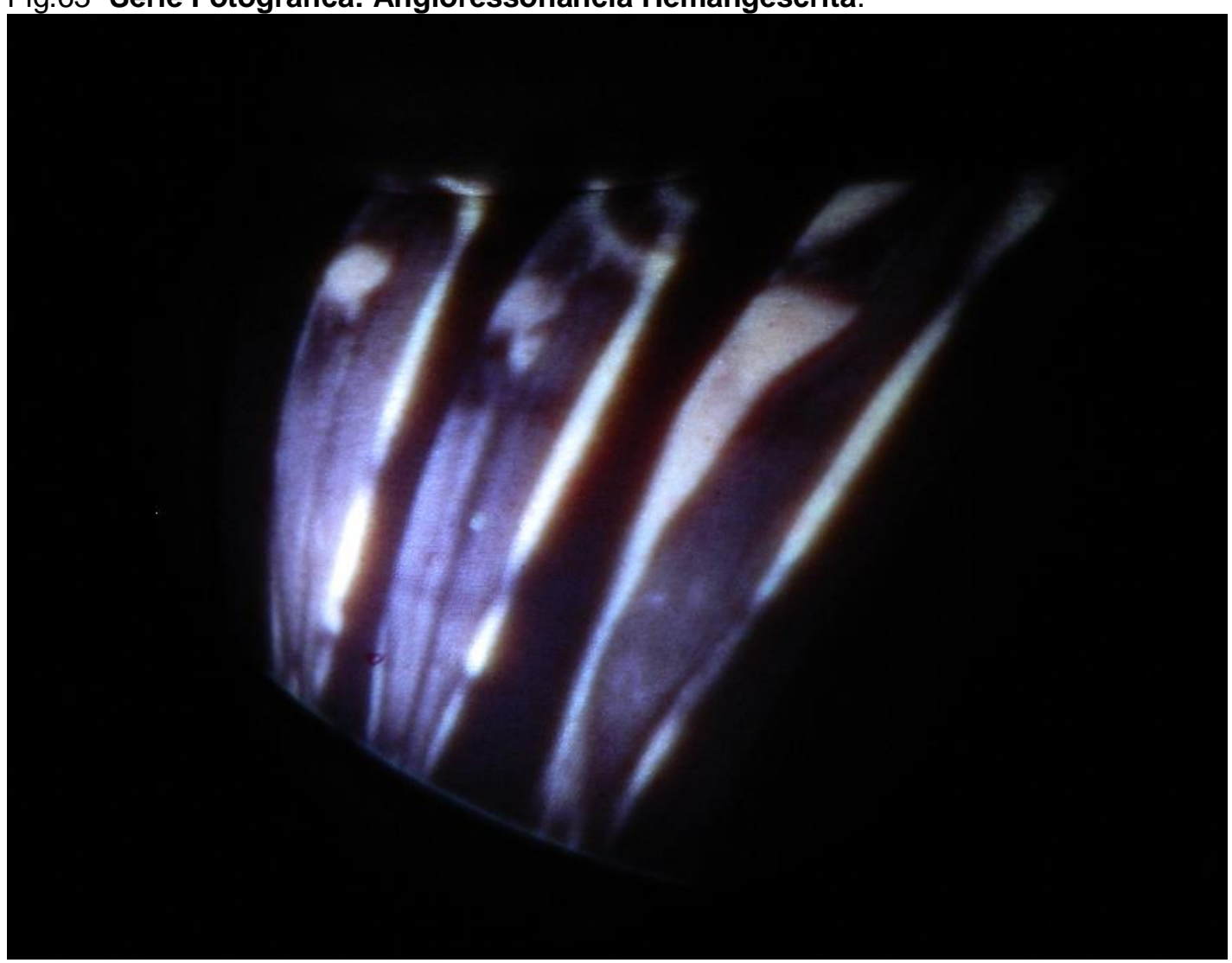

Foto: Tatiana Rodrigues. Local: Brasília, 20 fev. 2014. Série de 58 fotografias.

${ }^{78} \mathrm{C}$. escuro ópt. tipo de iluminação us. em microscopia para realçar a luminosidade [Para tal se faz incidir lateralmente sobre o objeto feixes luminosos, de modo a formar uma imagem brilhante mantendo o fundo escuro.] Fonte: Dicionário Eletrônico Houaiss da Língua Portuguesa 3.0. 
Fig.64- Série Fotográfica: Angioressonância Hemangescrita.

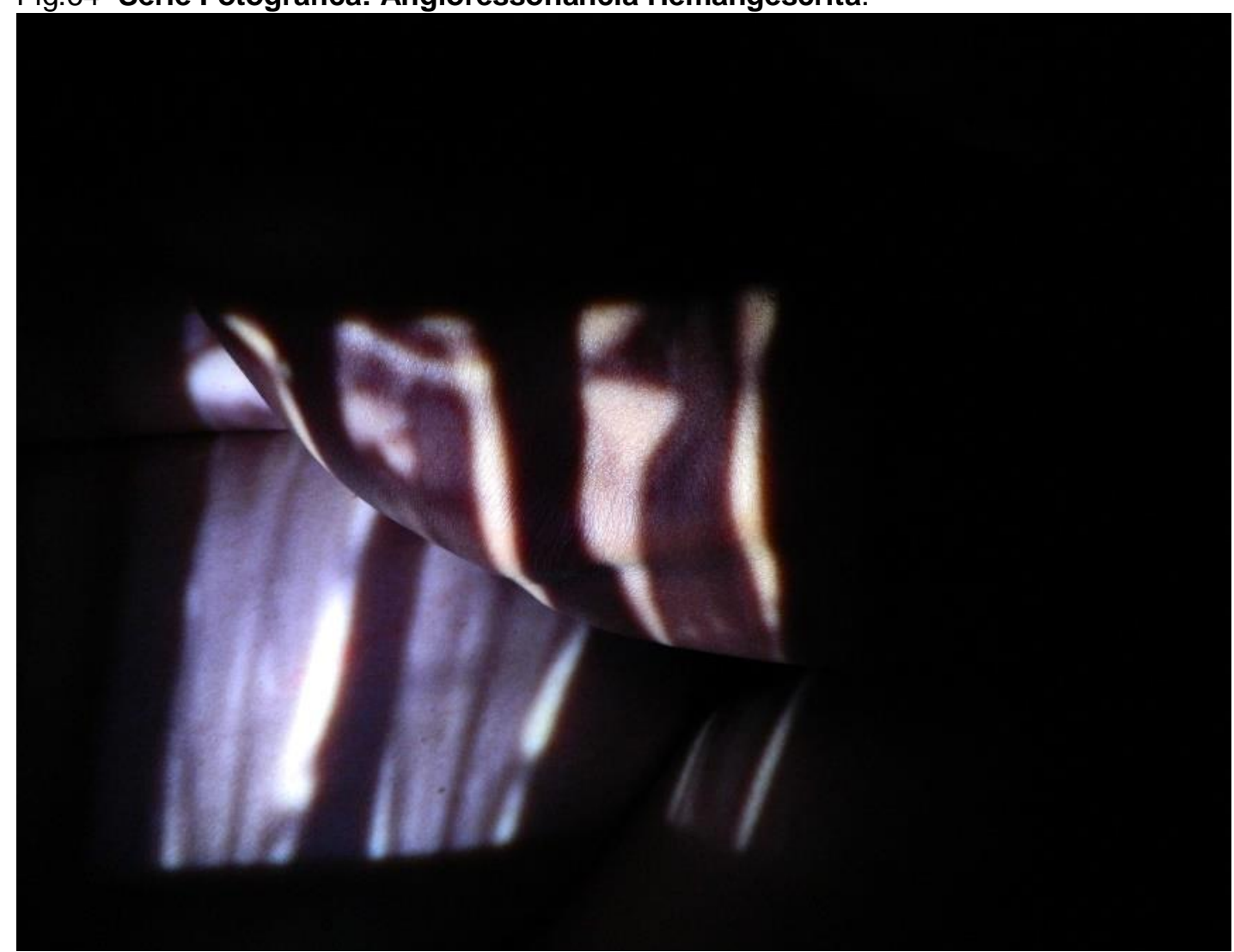

Foto: Tatiana Rodrigues. Local: Brasília, 20 fev. 2014. Série de 58 fotografias.

Fig.65- Série Fotográfica: Angioressonância Hemangescrita.

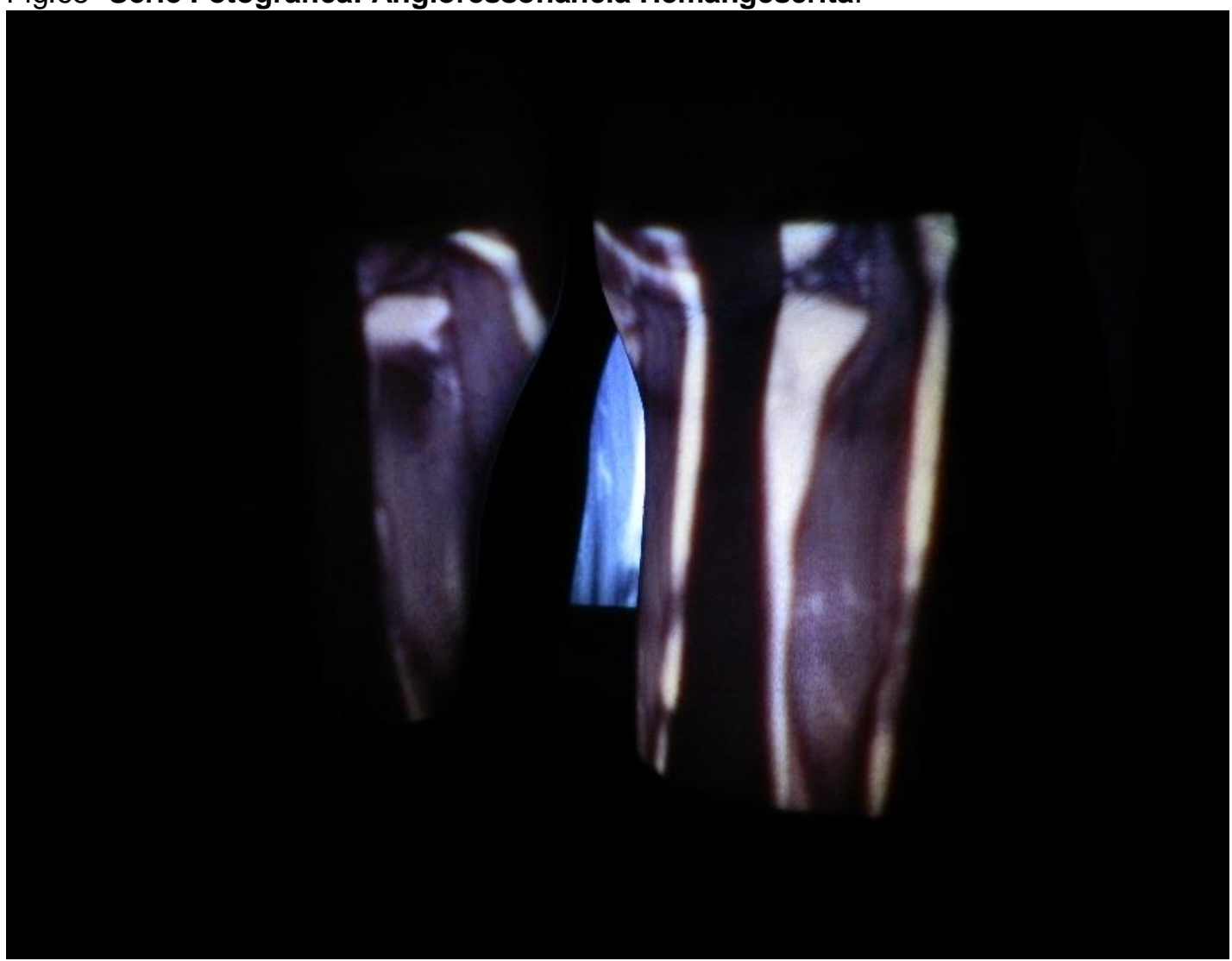

Foto: Tatiana Rodrigues. Local: Brasília, 20 fev. 2014. Série de 58 fotografias. 
Fig.66- Série Fotográfica: Angioressonância Hemangescrita.

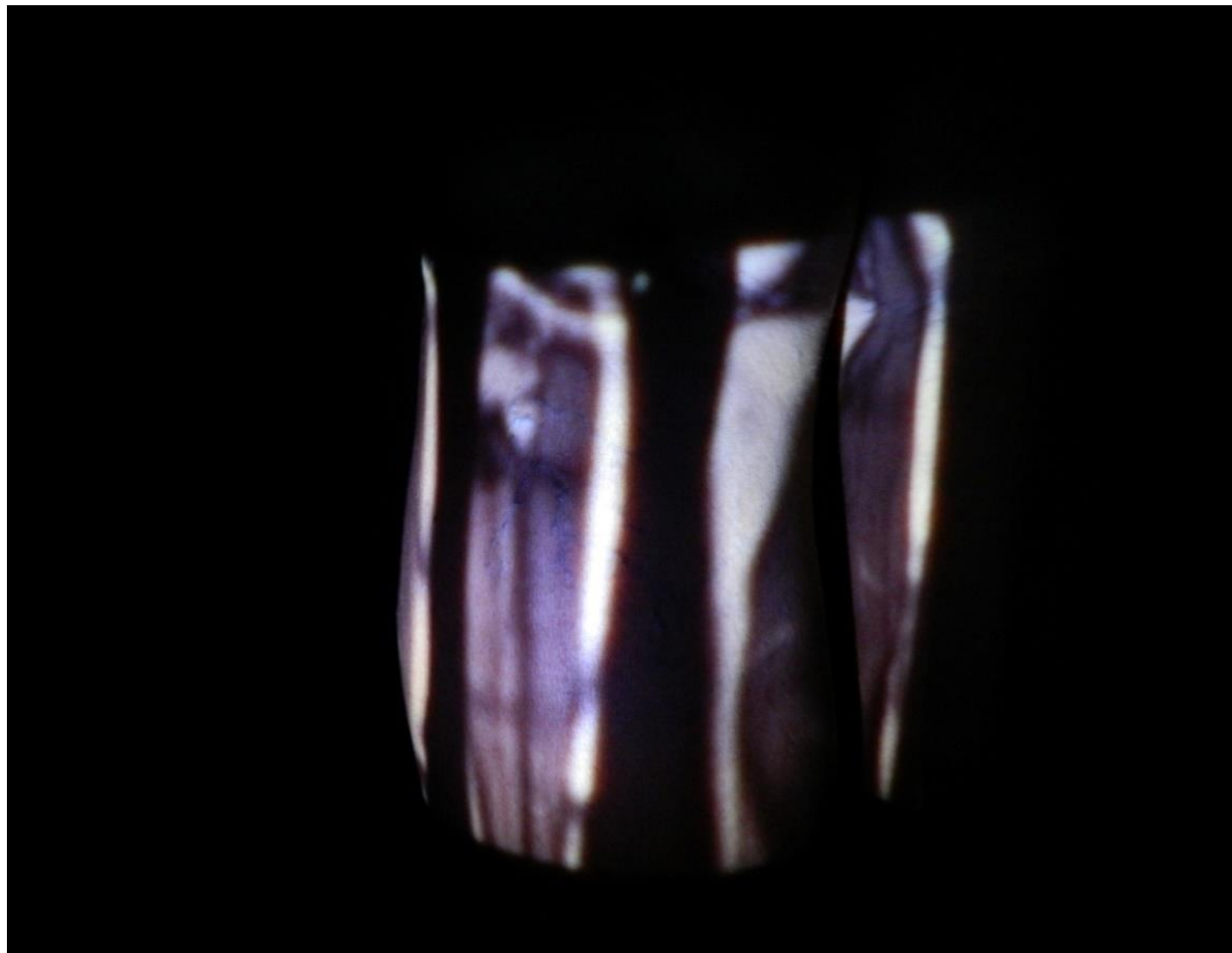

Foto: Tatiana Rodrigues. Local: Brasília, 20 fev. 2014. Série de 58 fotografias.

Fig.67- Série Fotográfica: Angioressonância Hemangescrita.

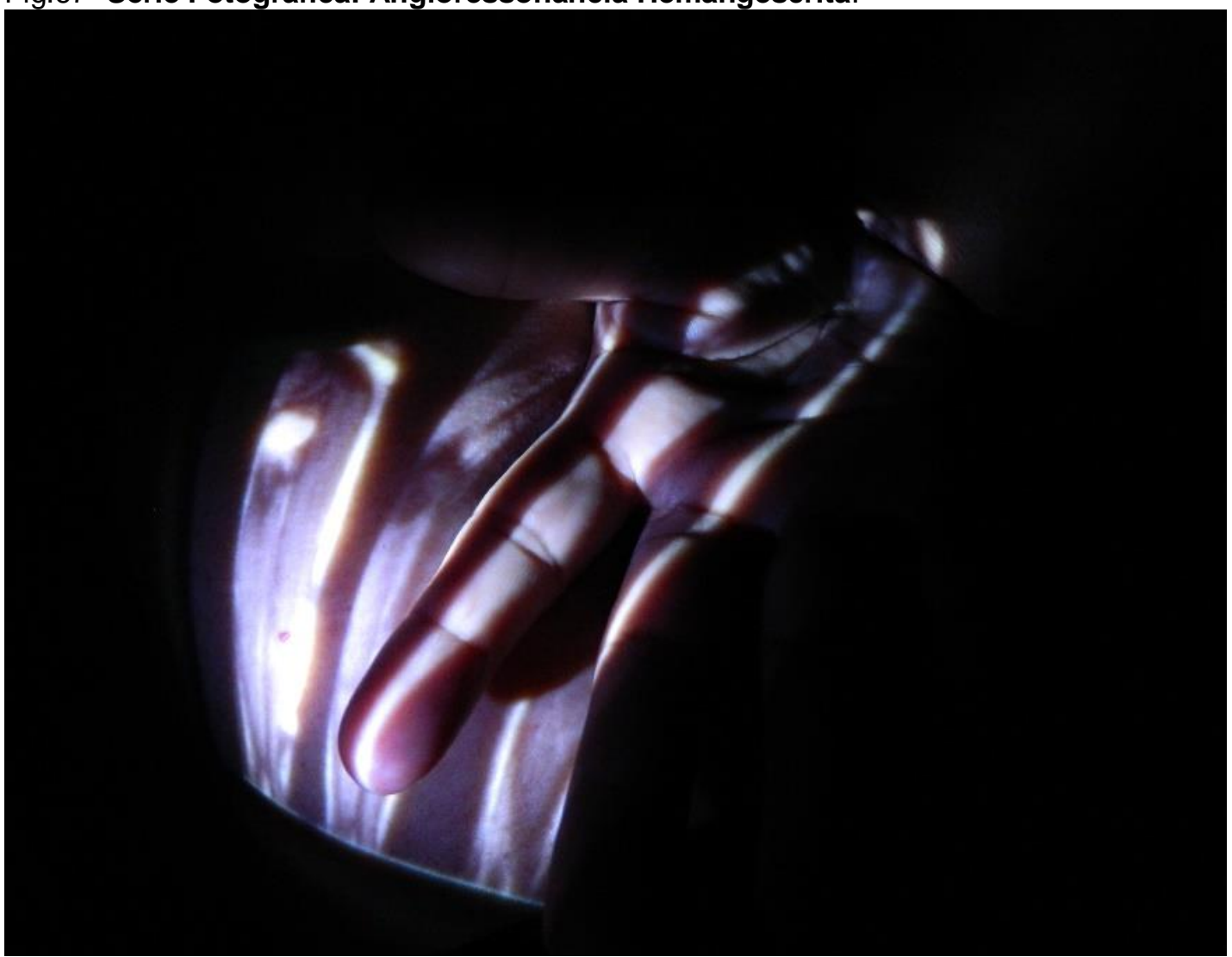

Foto: Tatiana Rodrigues. Local: Brasília, 20 fev. 2014. Série de 58 fotografias. 
Fig.68- Série Fotográfica: Angioressonância Hemangescrita.

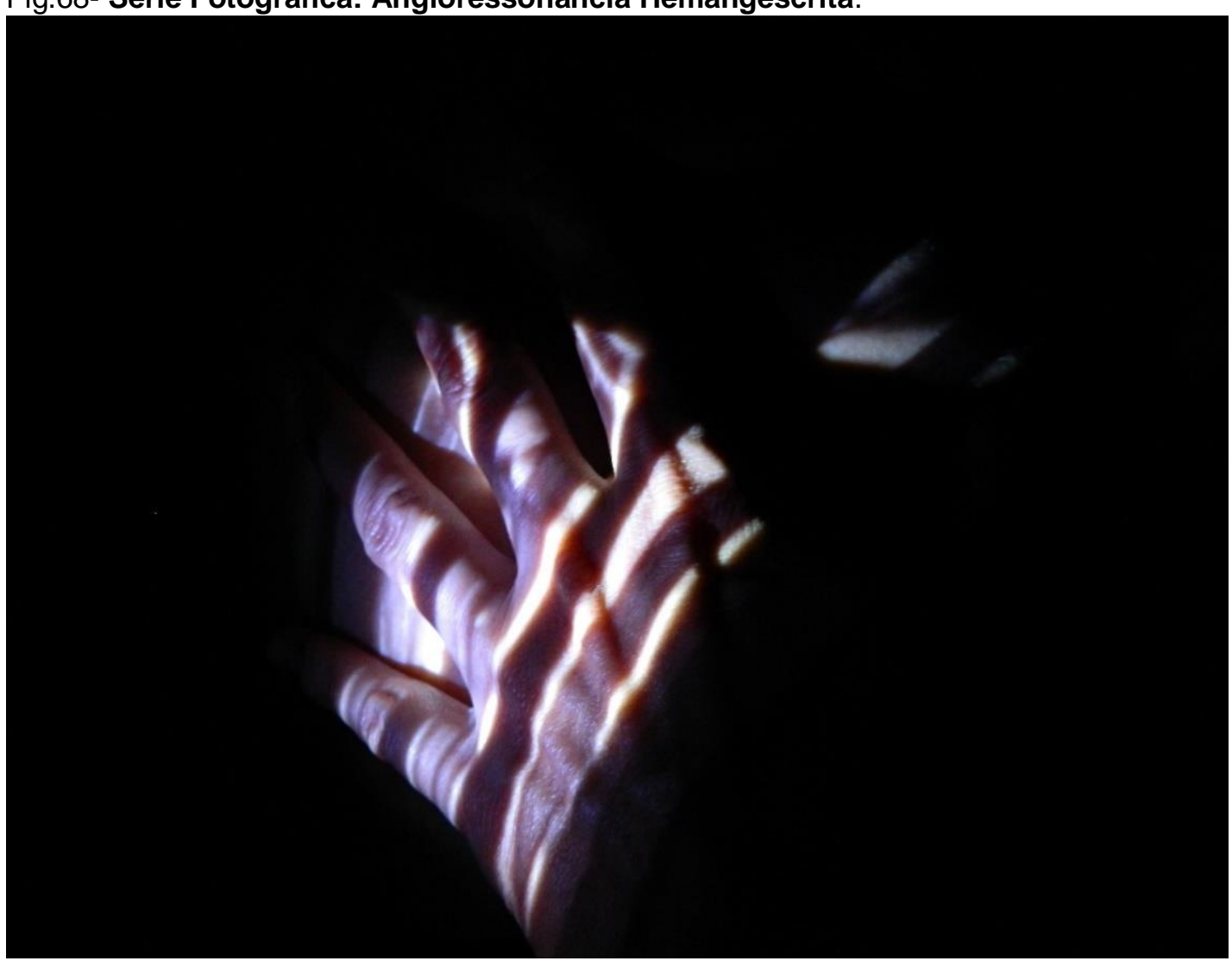

Foto: Tatiana Rodrigues. Local: Brasília, 20 fev. 2014. Série de 58 fotografias.

\subsubsection{Produção: Corporação hemangescrita}

Esta série fotográfica se originou a partir da projeção das imagens dos hemangiomas (figs. 33, 36 e 37) nos corpos-suportes (bonecos). Por ser o hemangioma considerado uma anomalia vascular congênita, característico do indivíduo desde ou antes do nascimento, o uso dos bonecos e dos bebês na série fotográfica dialoga com os acometimentos na infância. A aplicação do termo corporação, por sua vez, corroborou a ideia de trabalhar a projeção em um ajuntamento que pudesse representar a multiplicidade de acometidos com hemangioma espalhados pelos mais diversos lugares do mundo. A escolha dos ângulos fotográficos buscaram primar pela integração das sombras à composição, reforçando, assim, a representação de um grande quantitativo corpóreo.

O predomínio do uso de bonecas que representam o gênero feminino na composição fotográfica tem o propósito de enfatizar a predominância de incidência do 
hemangioma em mulheres, que chega a ser de 5 mulheres para 1 homem. A referência quanto à diversidade na cor da pele dos acometidos também foi um elemento considerado na concepção desta série e evidenciado nos corpos suportes dos bonecos.

Quanto à iluminação da composição, o único foco de luz utilizado foi o do mini projetor (figs. 48, 49 e 50) que tanto adaptou-se harmonicamente com o tamanho dos elementos corpóreos (bonecos) usados na projeção em relação à escolha do ambiente fotográfico sem iluminação. Nesse contexto, o uso das figuras com fundo preto nas projeções ajudou a reforçar as formas do hemangioma que, muitas vezes, fazem alusão às extensões territoriais de países e/ou continentes.

Figs.69 e 70- Série fotográfica: Corporação hemangescrita 1.

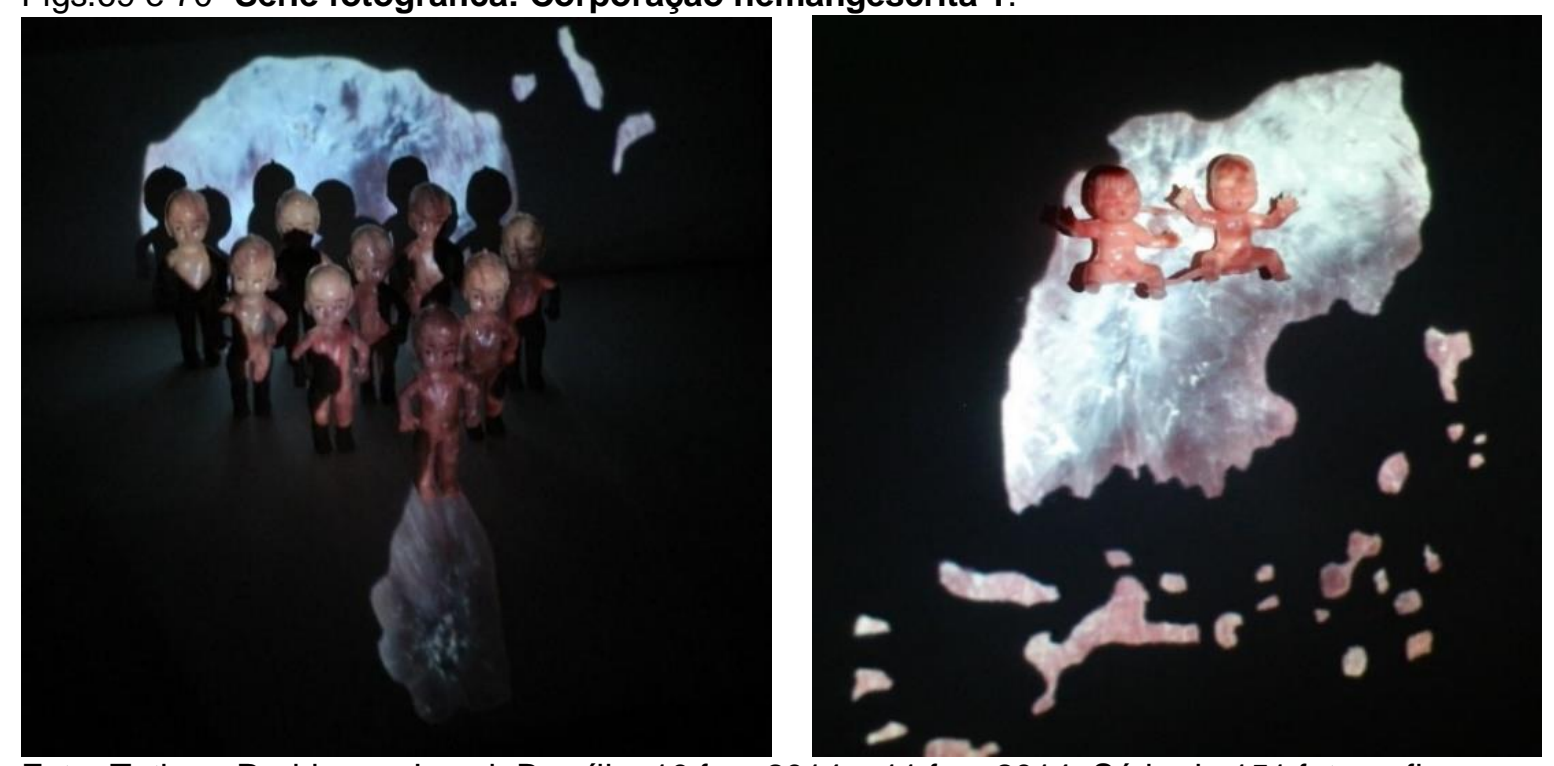

Foto: Tatiana Rodrigues. Local: Brasília, 10 fev. 2014 e 11 fev. 2014. Série de 151 fotografias.

A análise dos personagens Kafka e Bartleby por Pelbart (2003) no texto $O$ corpo do Informe foi tomada como ponto de referência teórico para a construção fotográfica desta série. Isso porque o autor trabalha com a concepção de que os corpos esquálidos dos personagens, de gestualidade inerte, passividade originária haviam se tornado ativos justamente a partir da passividade constitutiva que, sem negá-la, fazem dela um acontecimento. No trecho a seguir, apresento as considerações do autor que ajudam a elucidar as correlações com o planejamento do trabalho compositivo. 
Pensemos na fragilidade desses corpos, próximos do inumano, em posturas que tangenciam a morte, e que no entanto encarnam uma estranha obstinação, uma recusa inabalável. Nessa renúncia ao mundo pressentimos o signo de uma resistência. Aí se afirma algo essencial do próprio mundo. Nesses seres somos confrontados a uma surdez que é uma audição, uma cegueira que é uma vidência, um torpor que é uma sensibilidade exacerbada, uma apatia que é puro páthos, uma fragilidade que é indício de uma vitalidade superior. (PELBART, 2003, p. 43-44).

Nesse contexto, a utilização dos corpos dos bonecos buscou reforçar a concepção de Pelbart (2003) do corpo "próximo do inumano". Ademais, a corporação desses seres inanimados se propôs a representar a gestualidade inerte dos corpos que carregam consigo um acometimento que, apesar de diferenciá-los dos demais, pode constituir-se no signo de uma resistência. A mudez inerente a esses corpos assume posturas que "falam" coletivamente por meio da complexidade significativa das criações imagéticas.

Figs.71 e 72- Série fotográfica: Corporação hemangescrita 1.

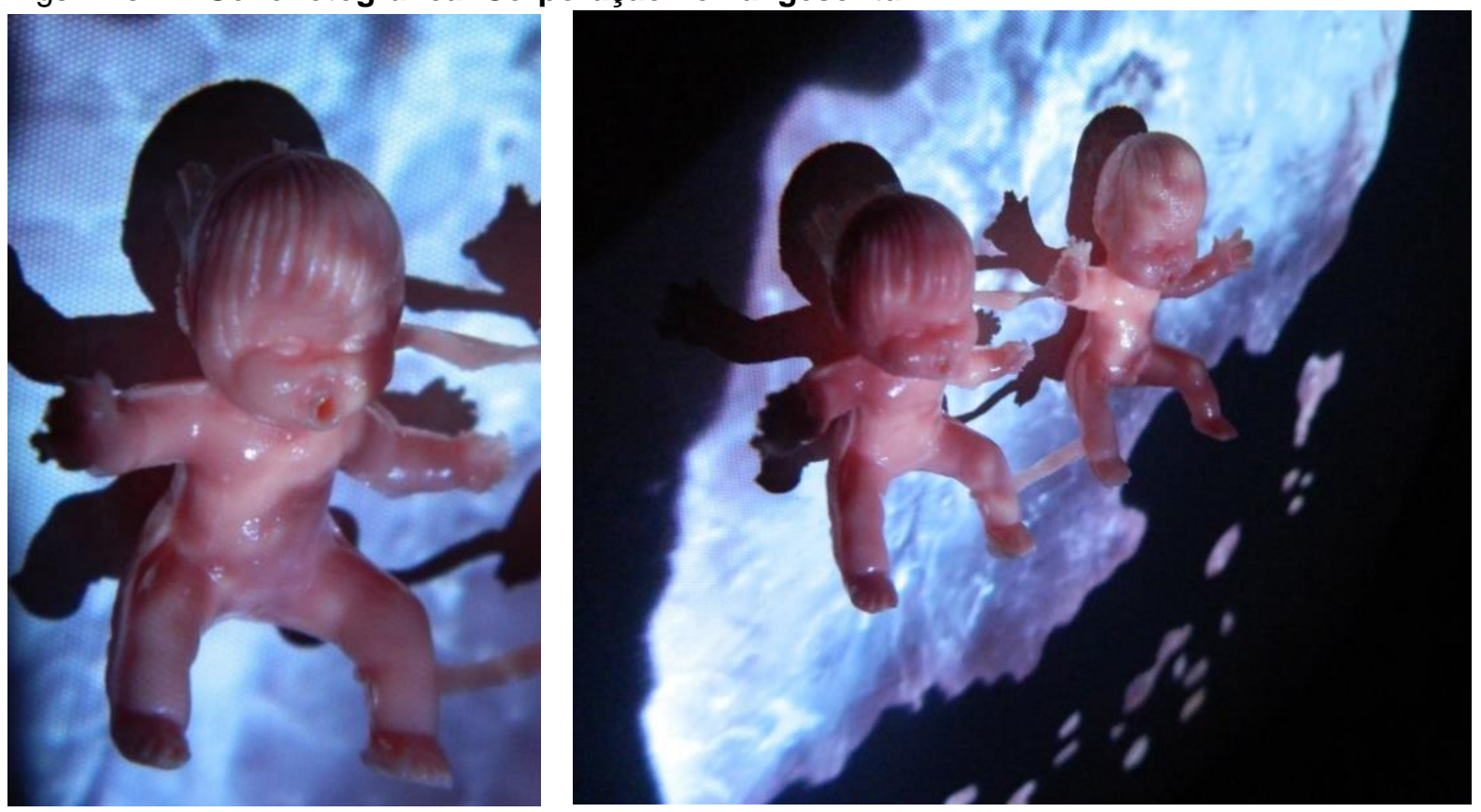

Foto: Tatiana Rodrigues. Local: Brasília, 11 fev. 2014. Série de 151 fotografias. 
Fig.73- Série fotográfica: Corporação hemangescrita 1.

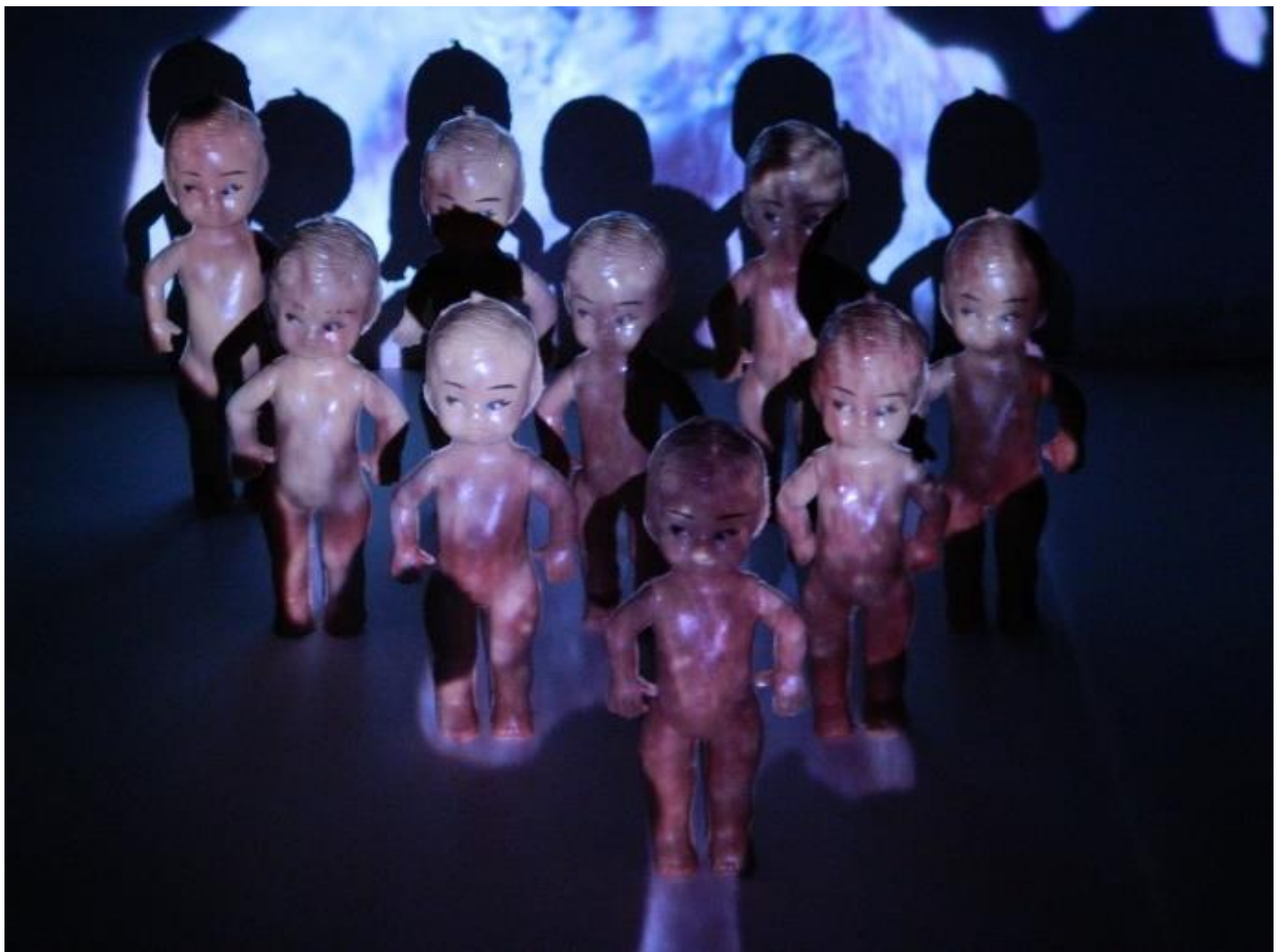

Foto: Tatiana Rodrigues. Local: Brasília, 10 fev. 2014. Série de 151 fotografias.

Fig.74- Série fotográfica: Corporação hemangescrita 1.

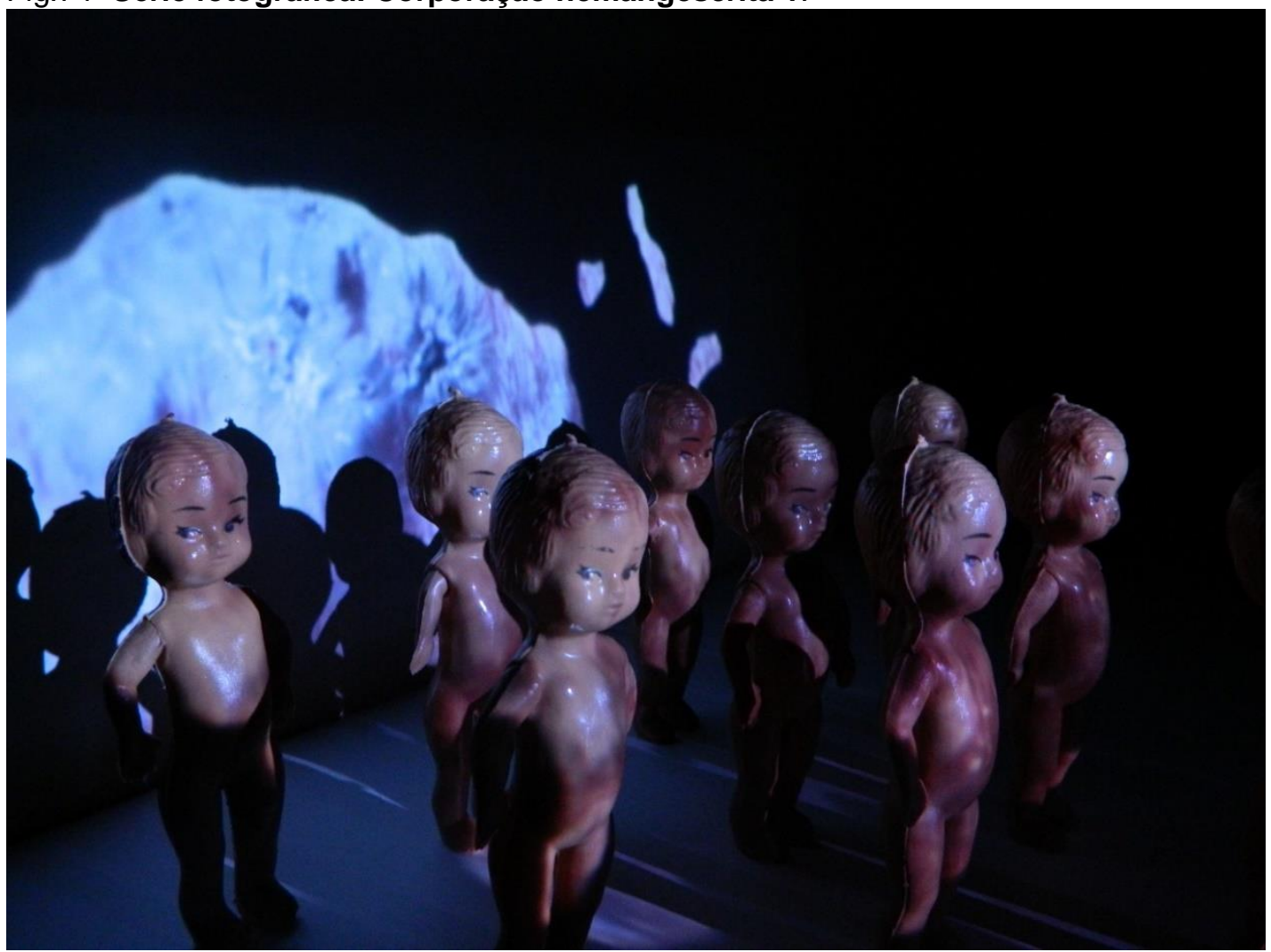

Foto: Tatiana Rodrigues. Local: Brasília, 10 fev. 2014. Série de 151 fotografias. 


\subsubsection{Poética: Corporação hemangescrita}

O hemangioma-luz* ilumina a frágil materialidade dos corpos revestidos pela encouraçada resistência da corporação. Corpos inanimados que carregam a projeção de um inusitado acometimento-luz*.

A variação da cor-plástico* que faz alusão à cor-pele* dos acometidos fundese com a cor-luz* do hemangioma que repousa sobre a corporação suas mais variadas porções de acometimentos.

As sombras que nascem dos corpos-suporte projetam seus desenhos-sombras* que, ao fundirem-se com a projeção do hemangioma-luz*, produz enigmáticas fusões imagéticas.

Os "olhos fotográficos" capturam a "imobilidade expressiva" da corporaçãoluz* que, ofuscada pela luz-hemangioma*, parece entregar-se a sua dominação acometedora. As angulações fotográficas permitem que os corpos pareçam repousar sobre os terrenos hemangescritos da projeção e/ou levitem nas asas do potencial-luz*.

Fig.75- Série fotográfica: Corporação hemangescrita 1.

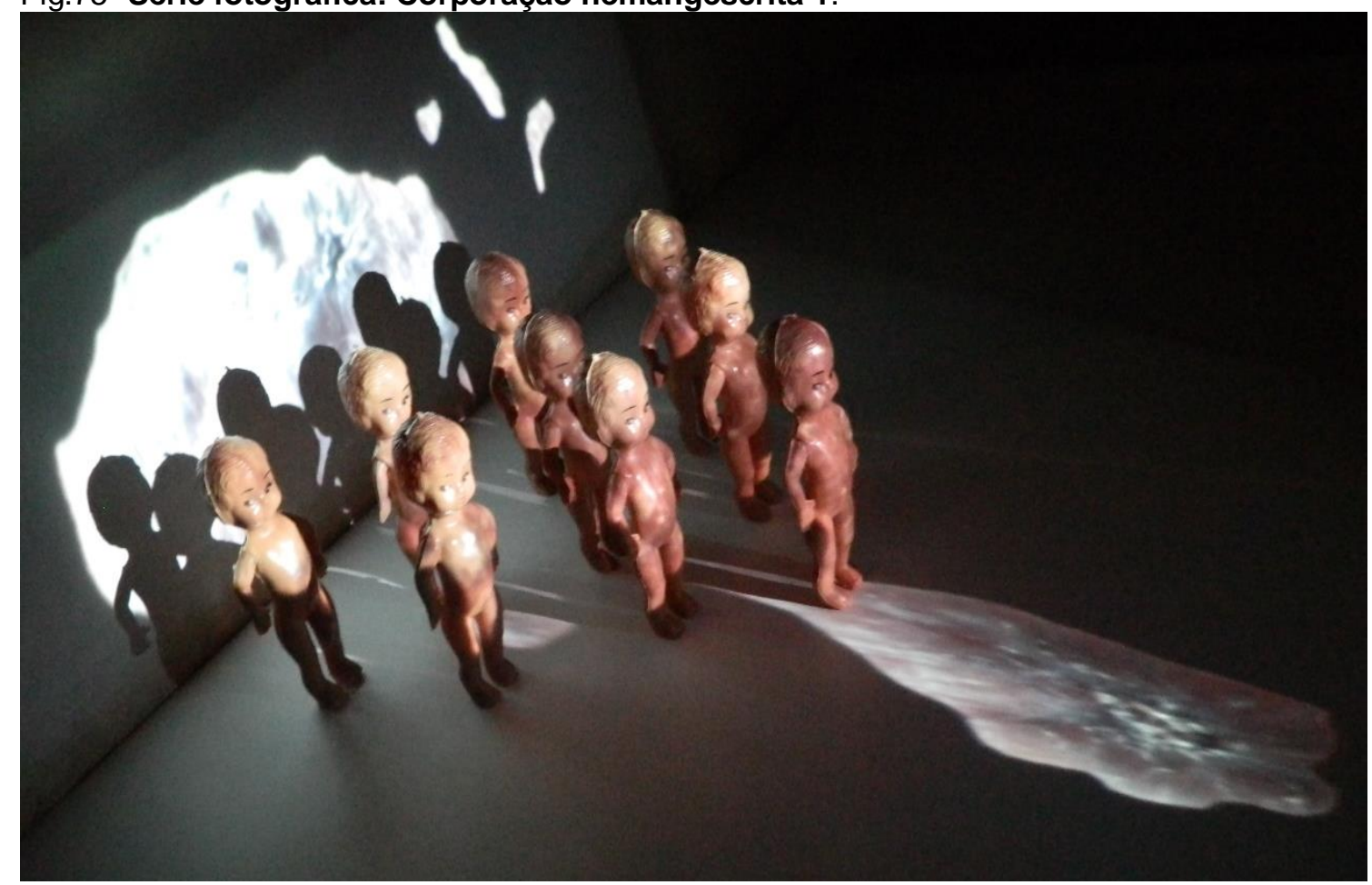

Foto: Tatiana Rodrigues. Local: Brasília, 10 fev. 2014. Série de 151 fotografias. 
Fig.76- Série fotográfica: Corporação hemangescrita 1.

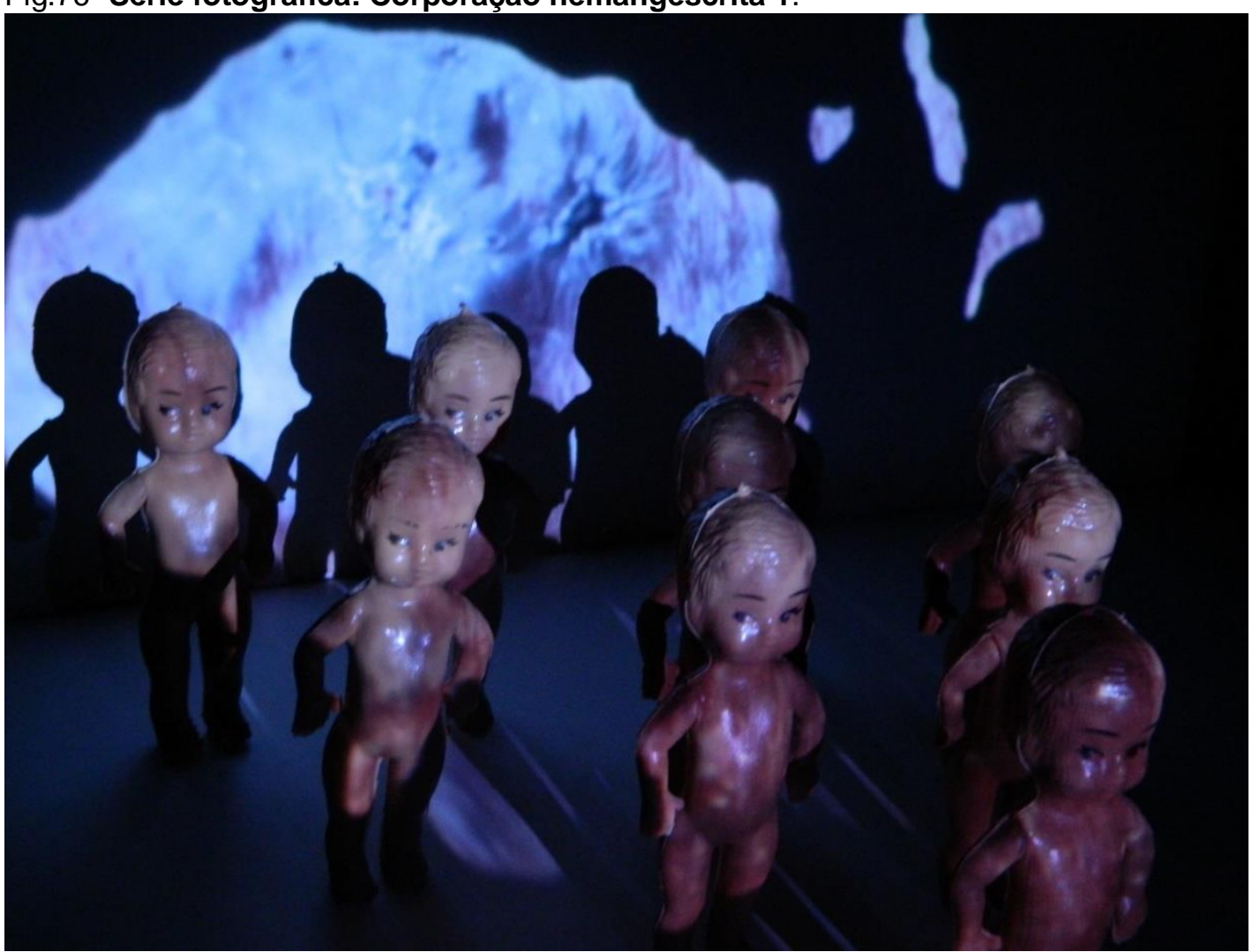

Foto: Tatiana Rodrigues. Local: Brasília, 10 fev. 2014. Série de 151 fotografias.

Fig.77- Série fotográfica: Corporação hemangescrita 1.

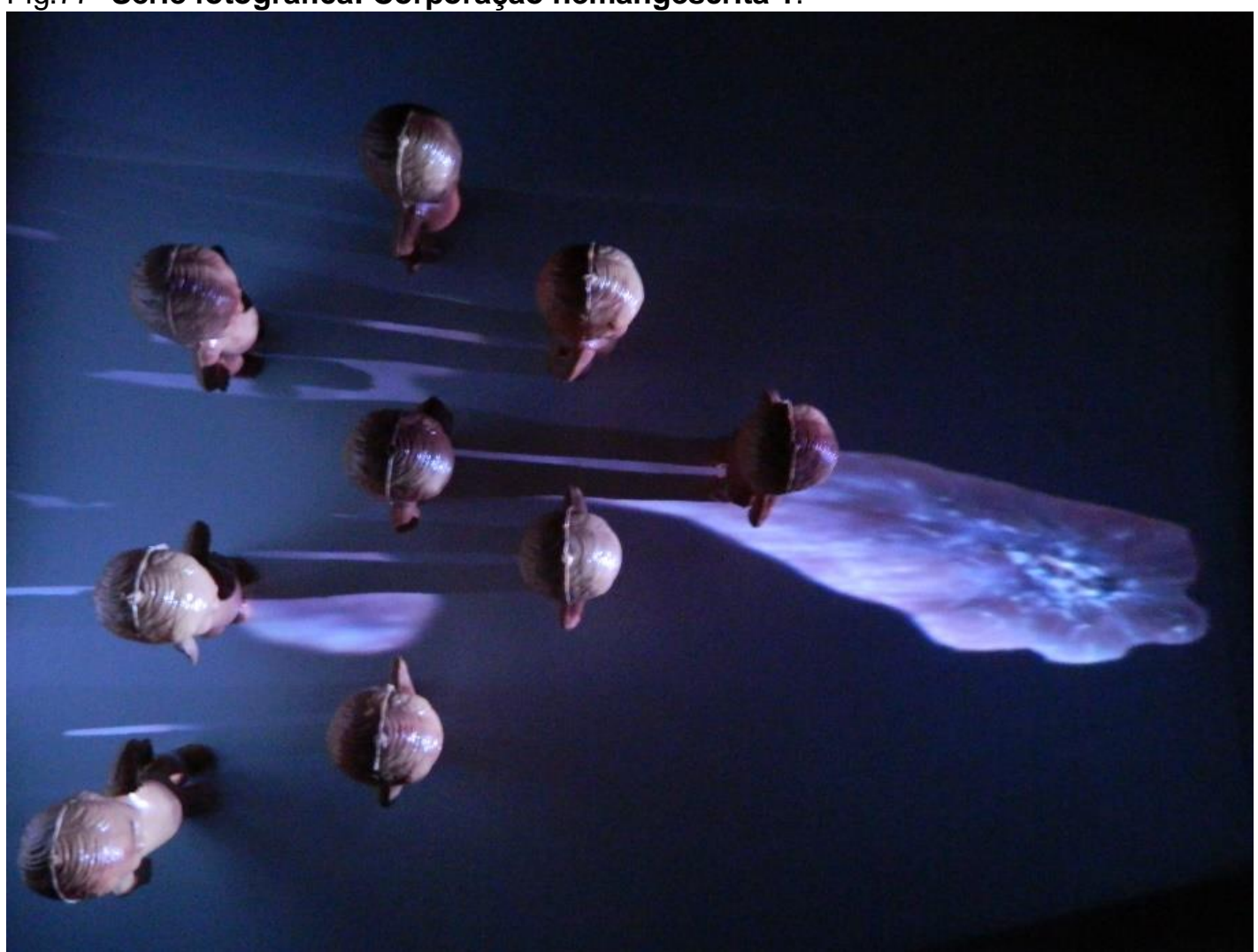

Foto: Tatiana Rodrigues. Local: Brasília, 10 fev. 2014. Série de 151 fotografias. 
Fig.78- Série fotográfica: Corporação hemangescrita 1.

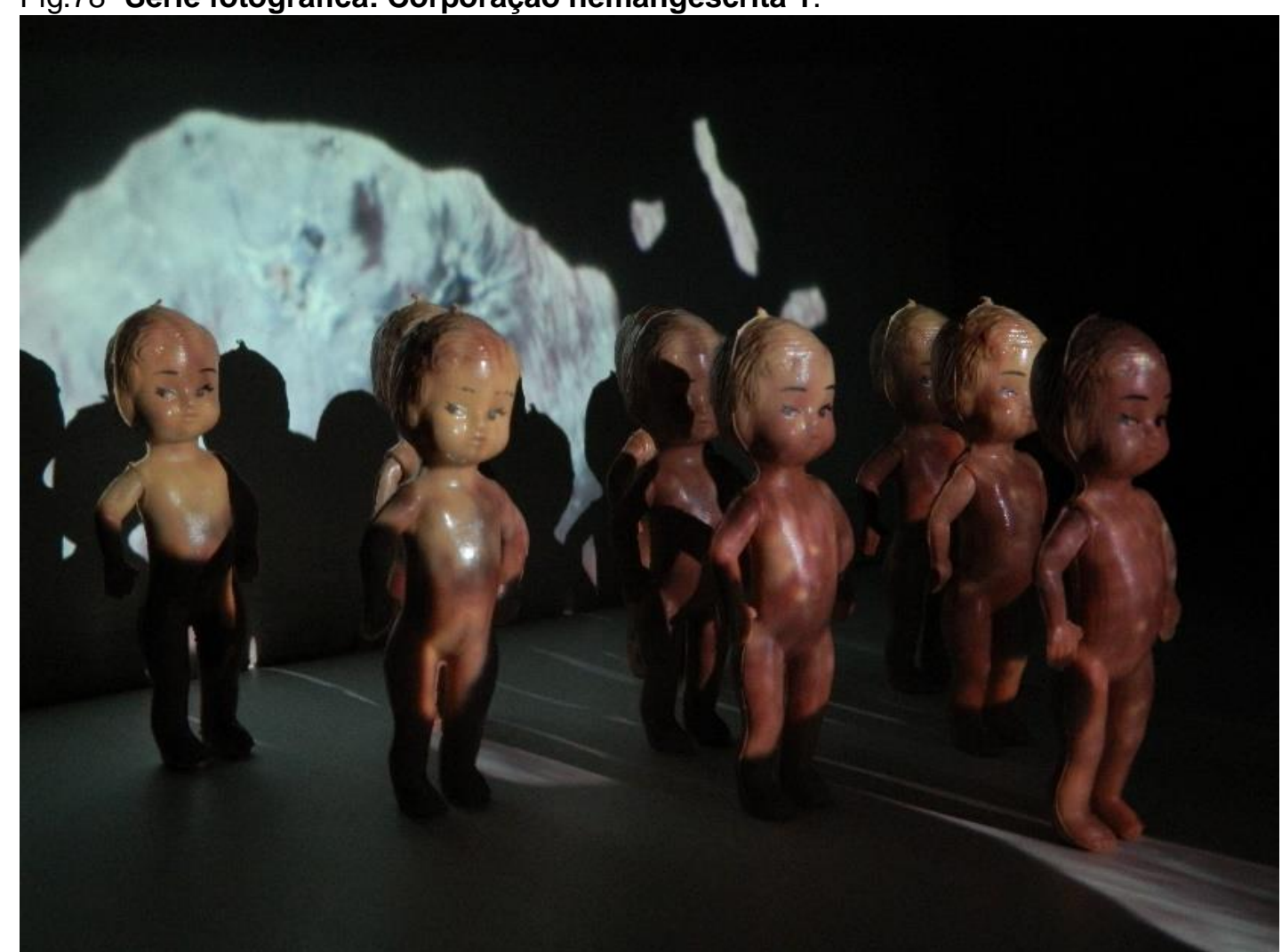

Foto: Tatiana Rodrigues. Local: Brasília, 10 fev. 2014. Série de 151 fotografias.

Fig.79- Série fotográfica: Corporação hemangescrita 1.

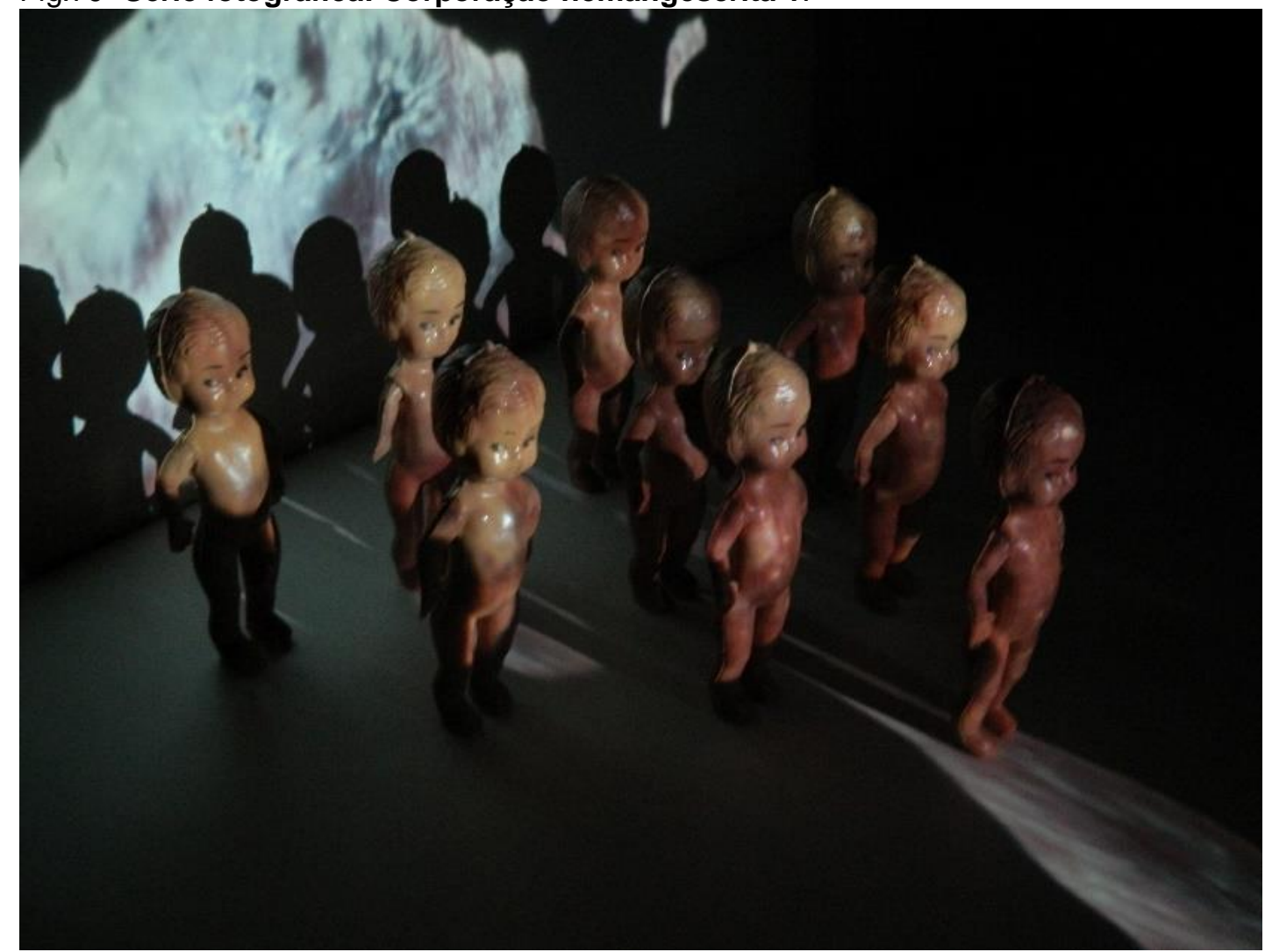

Foto: Tatiana Rodrigues. Local: Brasília, 10 fev. 2014. Série de 151 fotografias. 


\subsection{Corpos hemangescritos: macroimpressões artísticas- projeções-luz* para um novo olhar}

\subsubsection{Produção}

Criei a composição fotográfica denominada Corpos Hemangescritos a partir da fusão entre as projeções simultâneas das macroimpressões artísticas trabalhadas nas seguintes séries fotográficas: Fragmentos hemangescritos 1 e 2, Angioressonância hemangescrita e Corporação hemangescrita.

O processo produtivo foi elaborado de acordo com as seguintes etapas. Primeiro, os três projetores foram dispostos lado a lado conforme fig. 80 , a fim de que 0 foco de cada um deles convergisse em um mesmo ponto da tela de projeção. Em seguida, em cada projetor, foi disposto uma série fotográfica que, ao serem projetadas de maneira concomitante, possibilitou a integração entre as imagens. Em um próximo passo, realizei a captação fotográfica das imagens buscando os melhores ângulos e favorecimento de iluminação mais apropriado para cada composição. Após o término de uma primeira sequência de fotografias, os projetores foram reorganizados de maneira a favorecer novas perspectivas para a integração das imagens (fig.81). Sendo assim, uma nova sequência de fotos foi obtida em conformidade com os mesmos procedimentos anteriormente realizados.

A iluminação do ambiente contou com uma discreta incidência de luz natural, apesar do laboratório utilizado nesta produção ter tido todas as luzes apagadas e persianas das janelas fechadas.

Figs. 80 e 81- Convergência de projeções.
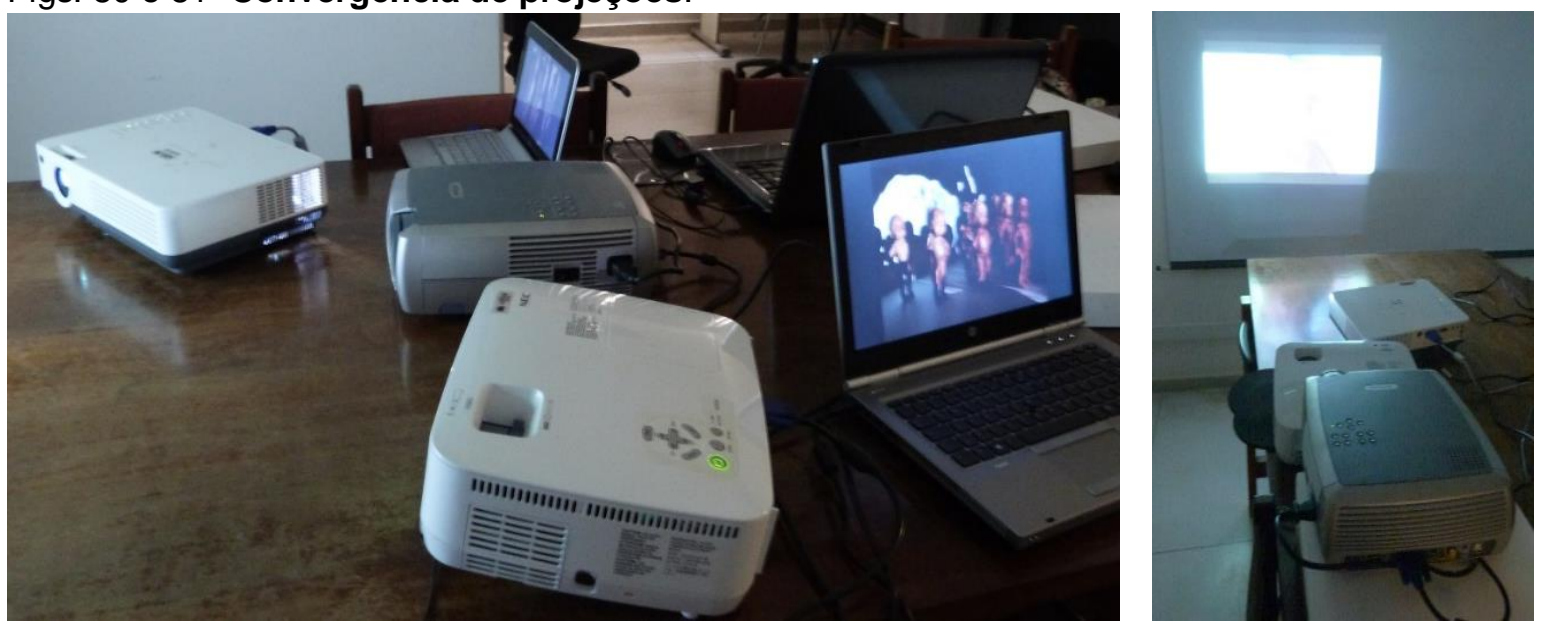

Foto: Tatiana Rodrigues. Local: Laboratório de Designer-ICC-UnB. Data:15 set. 2014. 


\subsubsection{Poética: convergência de projeções}

Neste processo composicional, a fusão-luz* das projeções viabiliza mais que uma interação imagética; ela fomenta o diálogo entre as macroimpressões artísticas construídas ao longo dos processos criativos.

A convergência-luz* que compila as macroimpressões dos corpos projeta-se rumo às composições que nascem em meio ao revelar-se e/ou ocultar-se das luzes e sombras fotográficas.

Corpos hemangescritos que, por meio do potencial-luz* das projeções e fotografias, tiveram seus corpos escritos pelo hemangioma-luz*. Corpos que carregam consigo a metamorfose-luz* de suas macroimpressões e projetam-se em um único ajuntamento de corpos-luz*.

Enfim, os corpos hemangescritos, bem como todas as macroimpressões artísticas, podem ser definidos poeticamente como o hemangioma constituído de luz que projetou-se rumo a uma escrita singular nos corpos-suporte que, apesar de sua efemeridade, se eternizará na captação fotográfica rumo a um novo olhar.

\section{Fig.82- Série fotográfica: Corpos hemangescritos.}

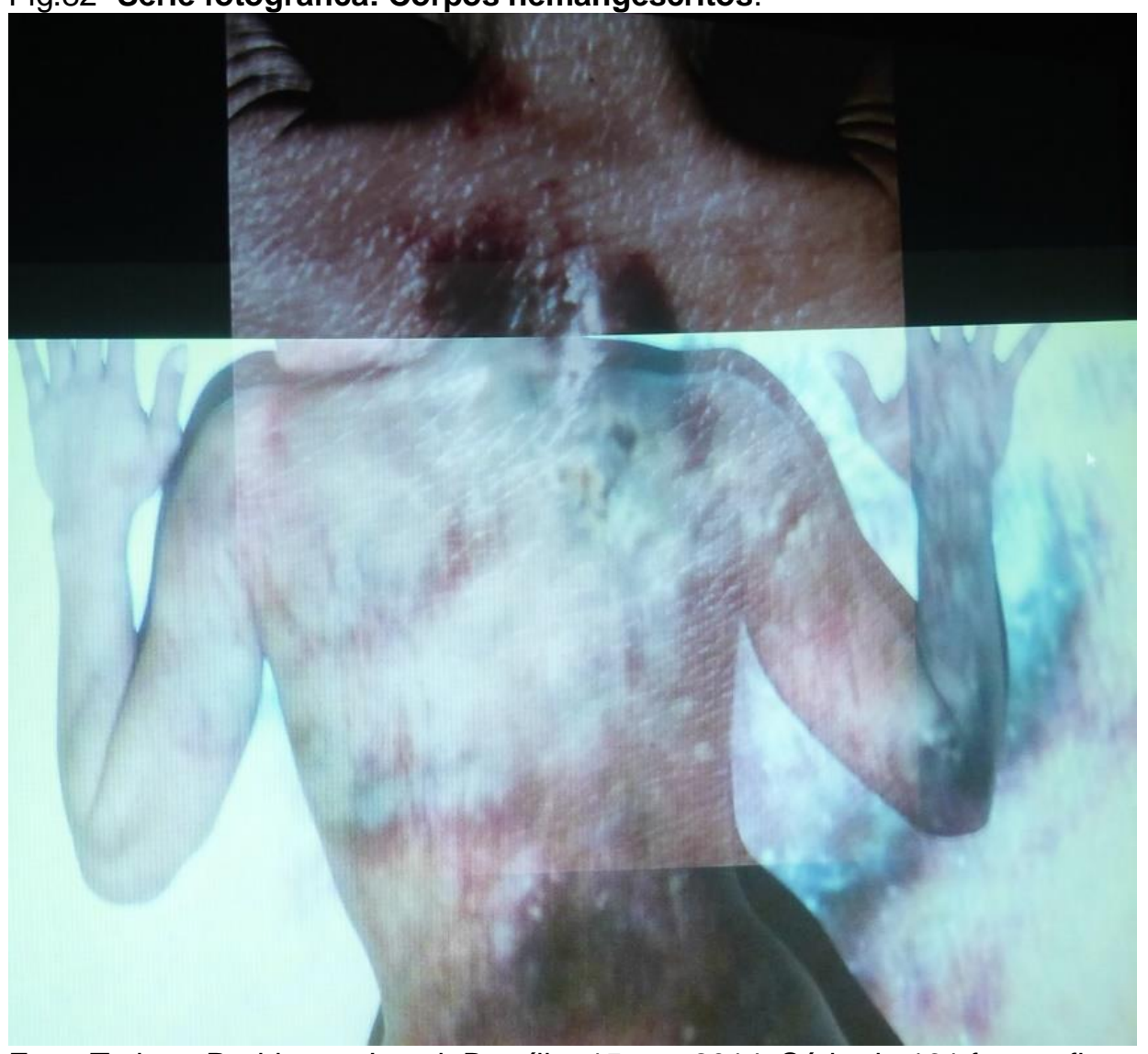

Foto: Tatiana Rodrigues. Local: Brasília, 15 set. 2014. Série de 161 fotografias. 
Fig.83- Série fotográfica: Corpos hemangescritos.

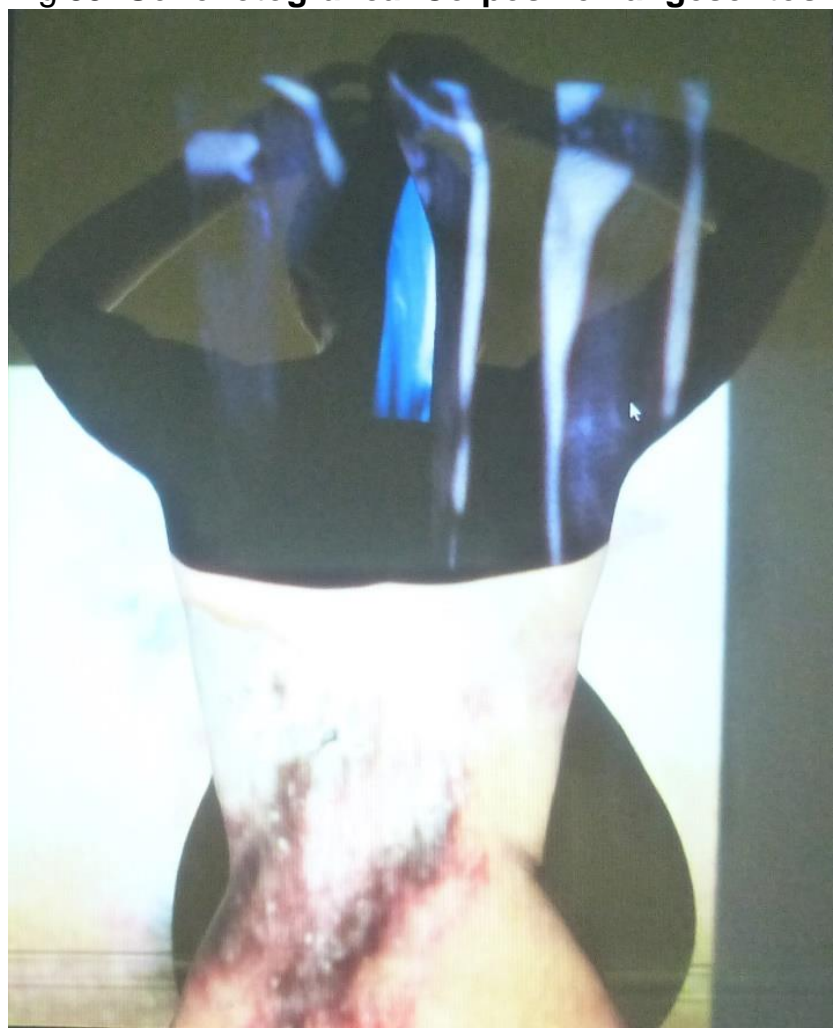

Foto: Tatiana Rodrigues. Local: Brasília, 15 set. 2014. Série de 161 fotografias.

Fig.84- Série fotográfica: Corpos hemangescritos.

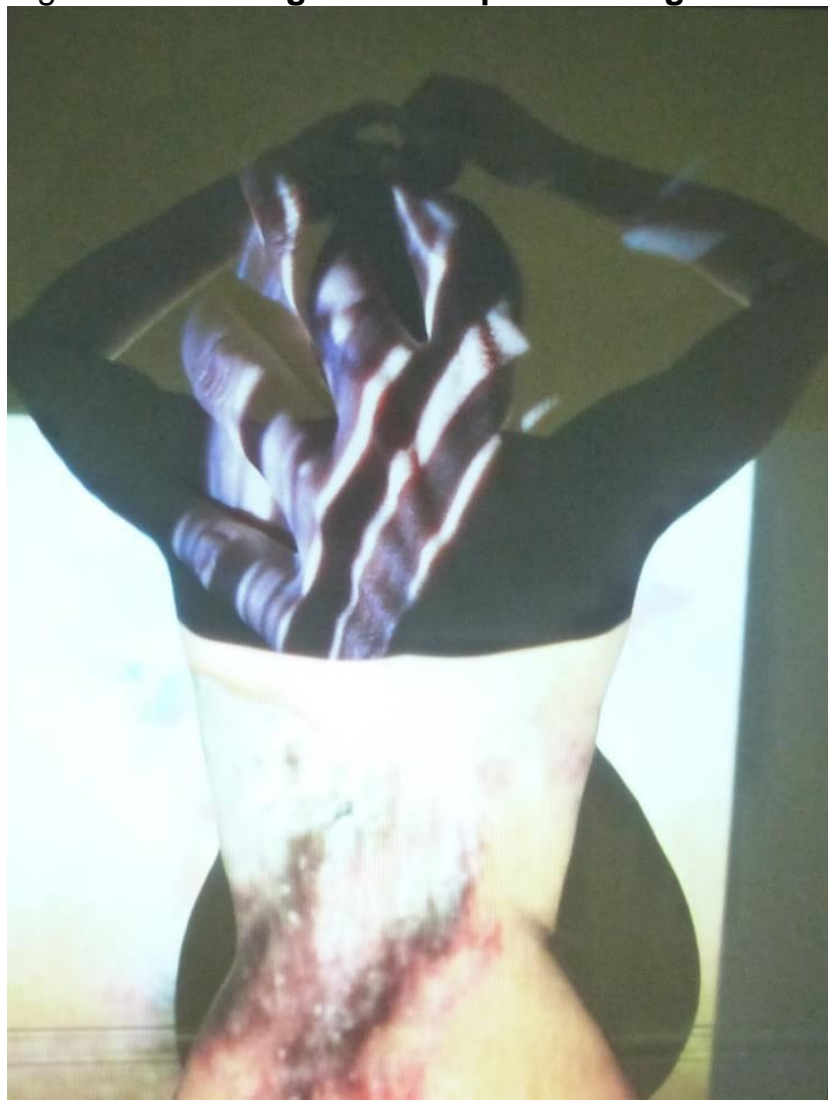

Foto: Tatiana Rodrigues. Local: Brasília, 15 set. 2014. Série de 161 fotografias. 
Fig.85- Série fotográfica: Corpos hemangescritos.

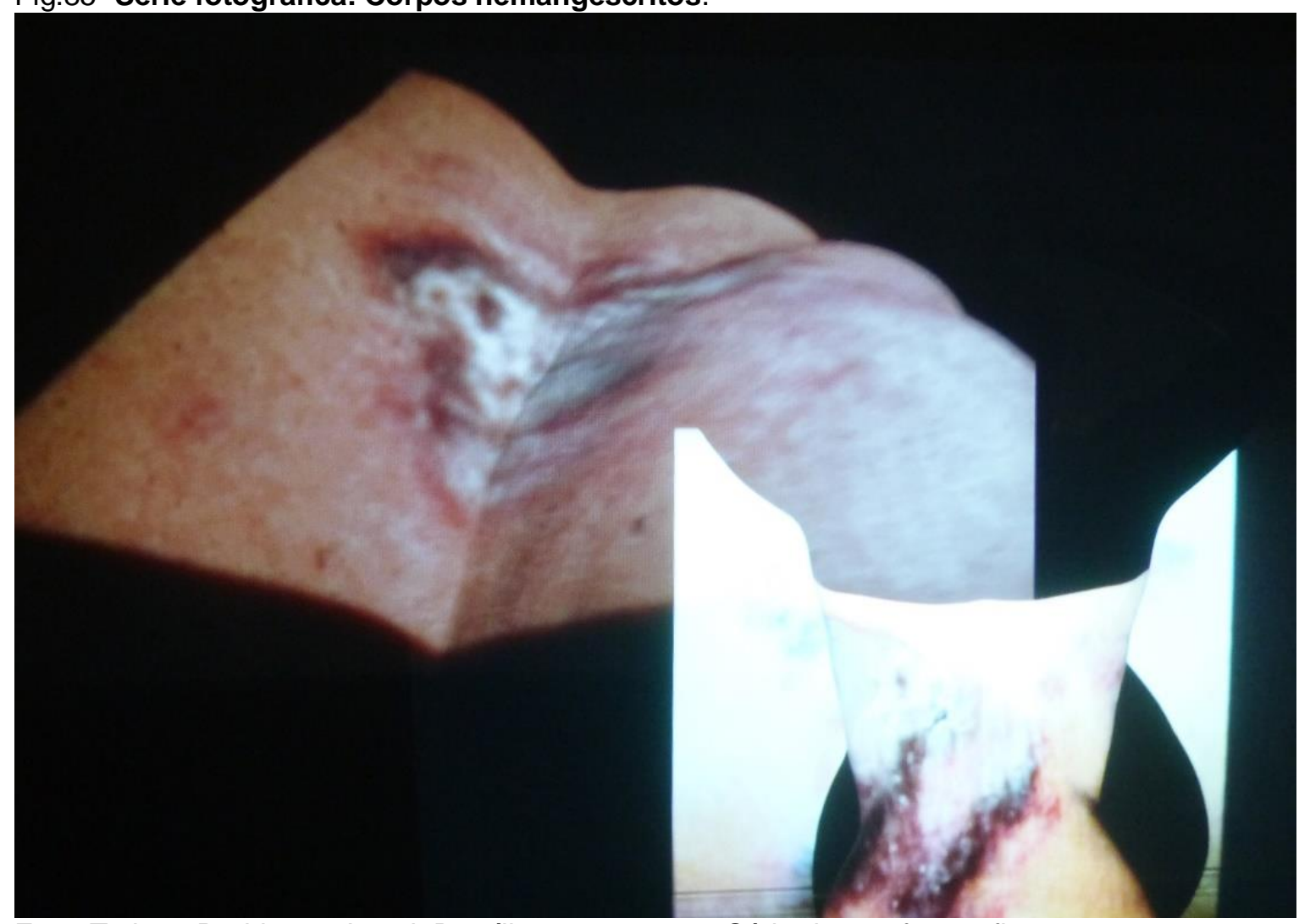

Foto: Tatiana Rodrigues. Local: Brasília, 15 set. 2014. Série de 161 fotografias.

Fig.86- Série fotográfica: Corpos hemangescritos.

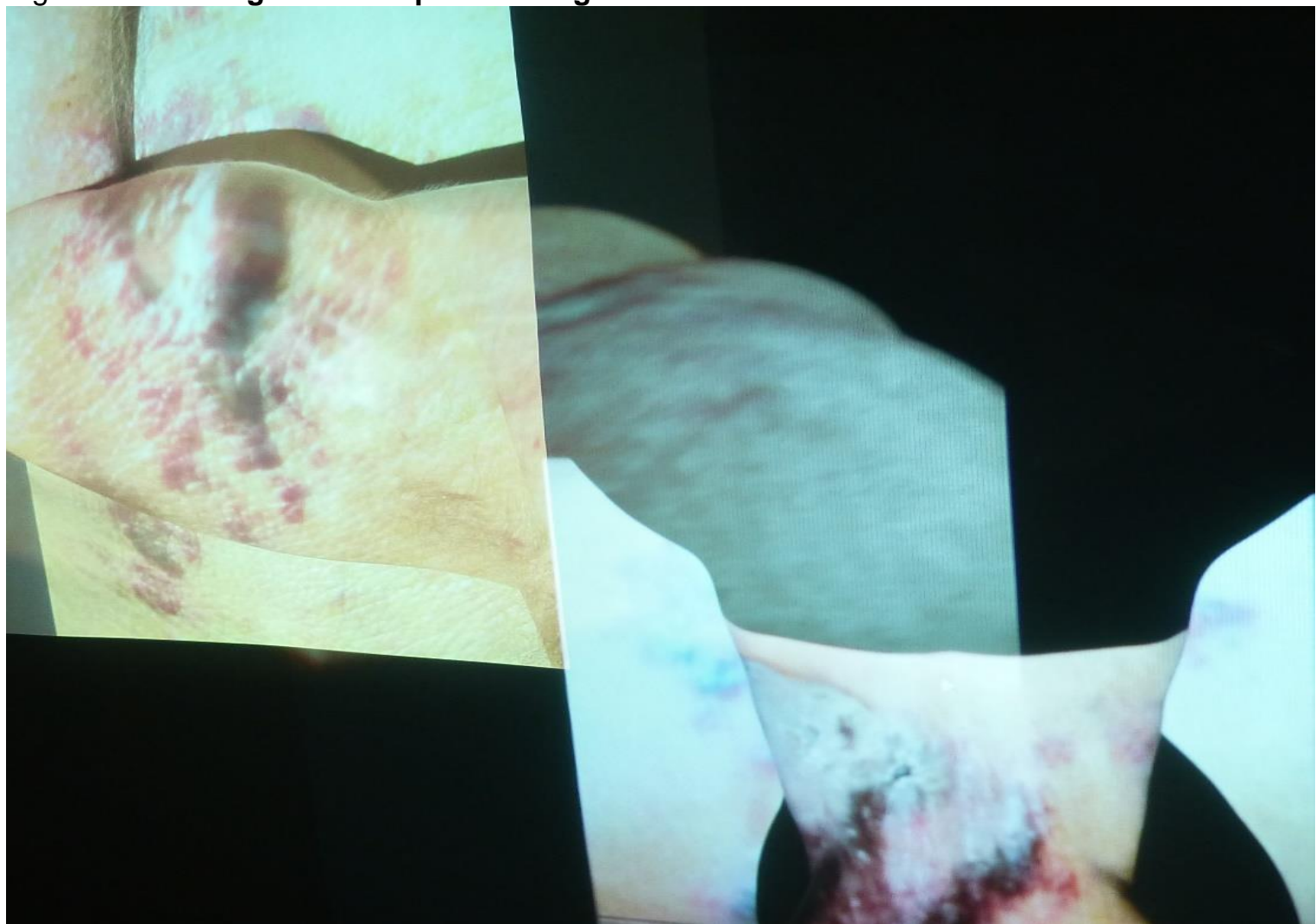

Foto: Tatiana Rodrigues. Local: Brasília, 15 set. 2014. Série de 161 fotografias. 
Fig.87- Série fotográfica: Corpos hemangescritos.

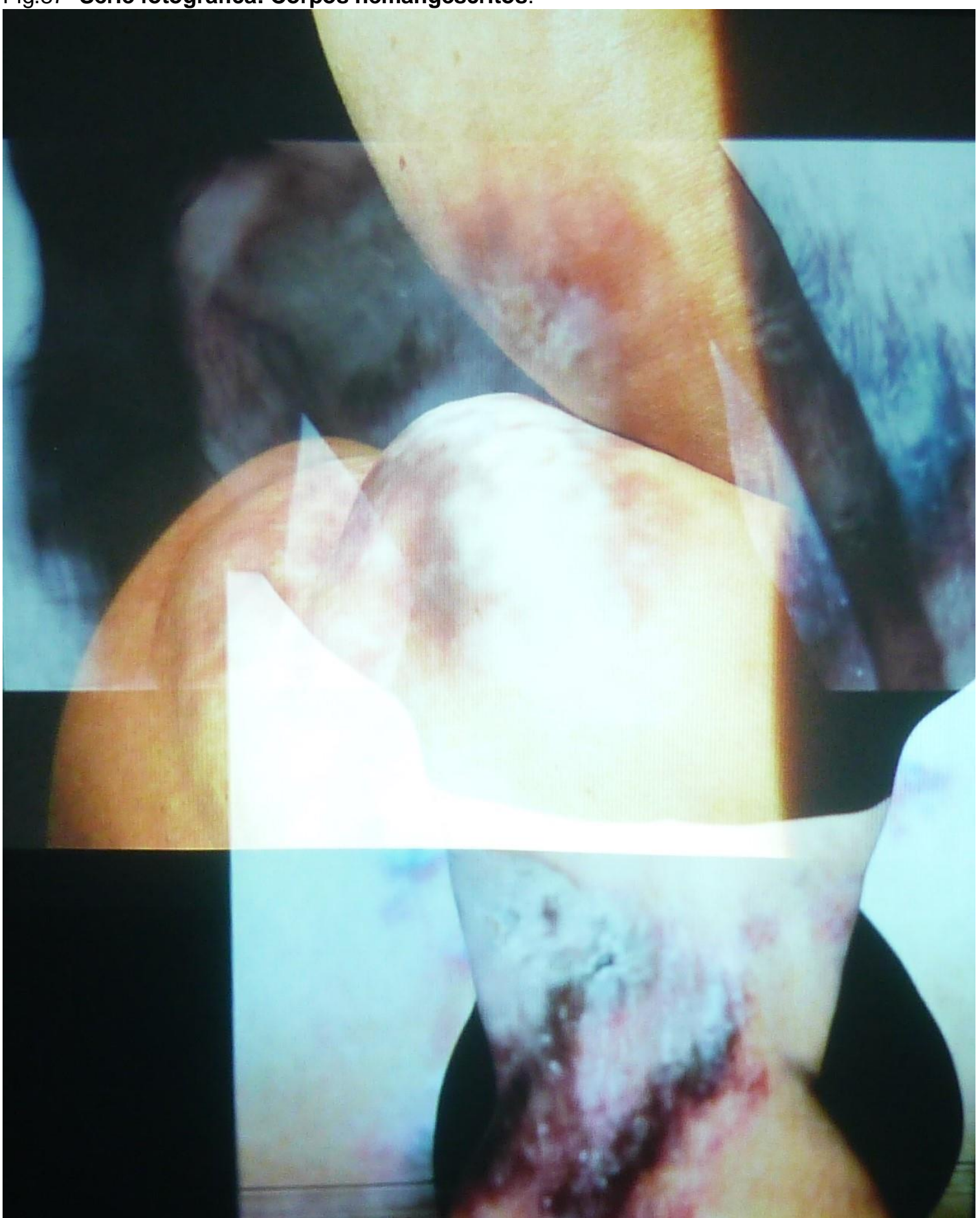

Foto: Tatiana Rodrigues. Local: Brasília, 15 set. 2014. Série de 161 fotografias. 
Fig.88- Série fotográfica: Corpos hemangescritos.

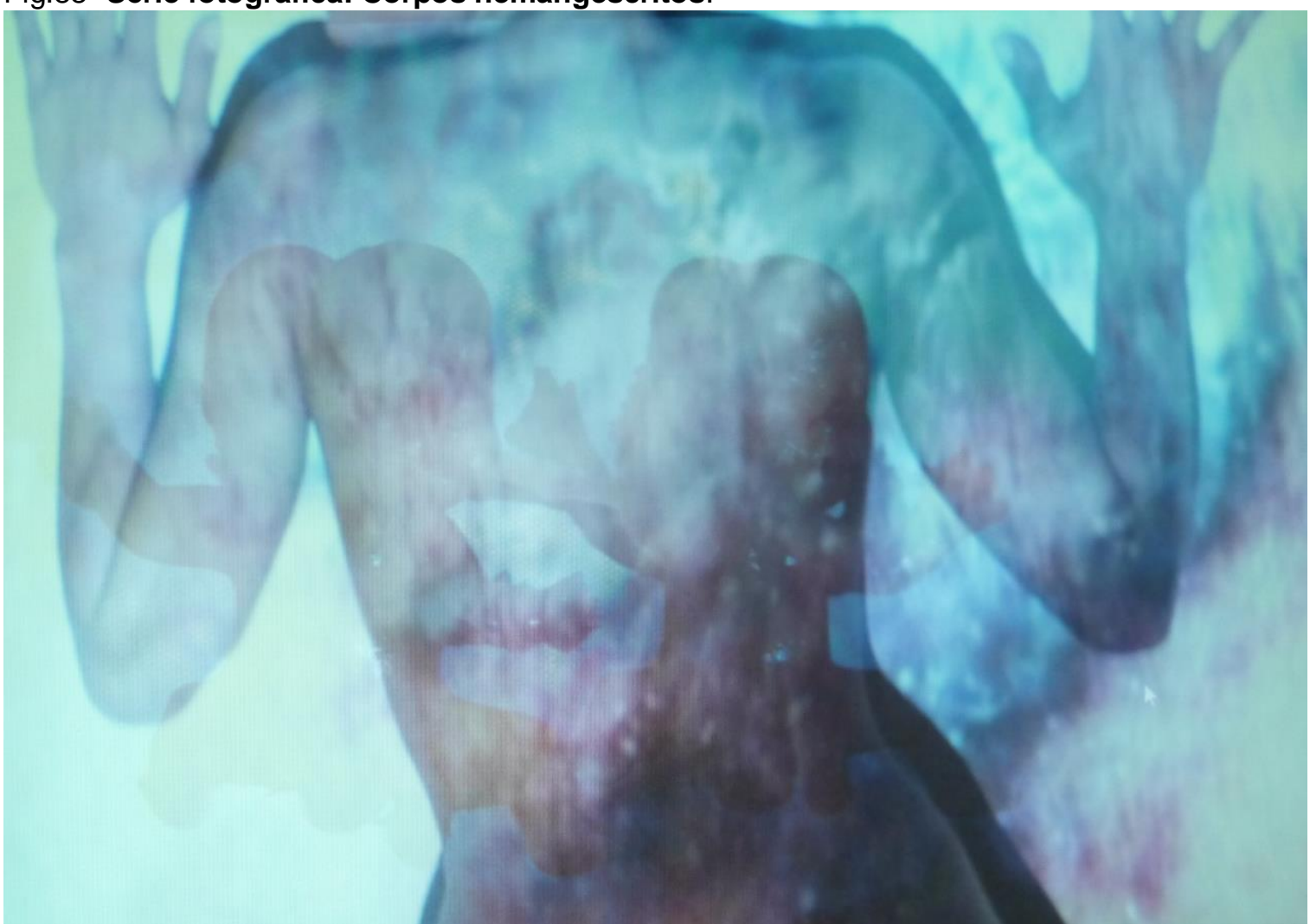

Foto: Tatiana Rodrigues. Local: Brasília, 15 set. 2014. Série de 161 fotografias.

Fig.89- Série fotográfica: Corpos hemangescritos.

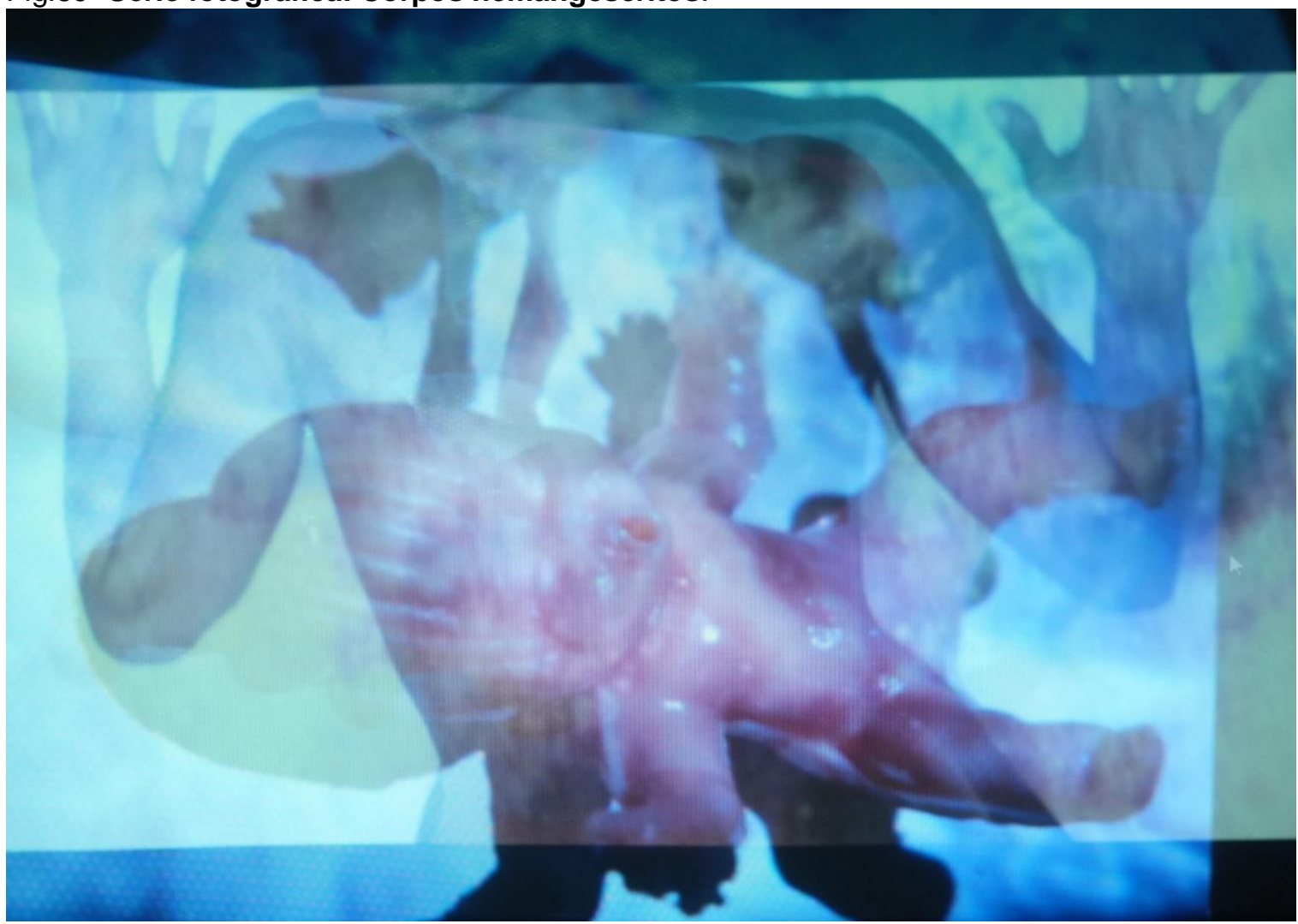

Foto: Tatiana Rodrigues. Local: Brasília, 15 set. 2014. Série de 161 fotografias. 
Fig.90- Série fotográfica: Corpos hemangescritos.

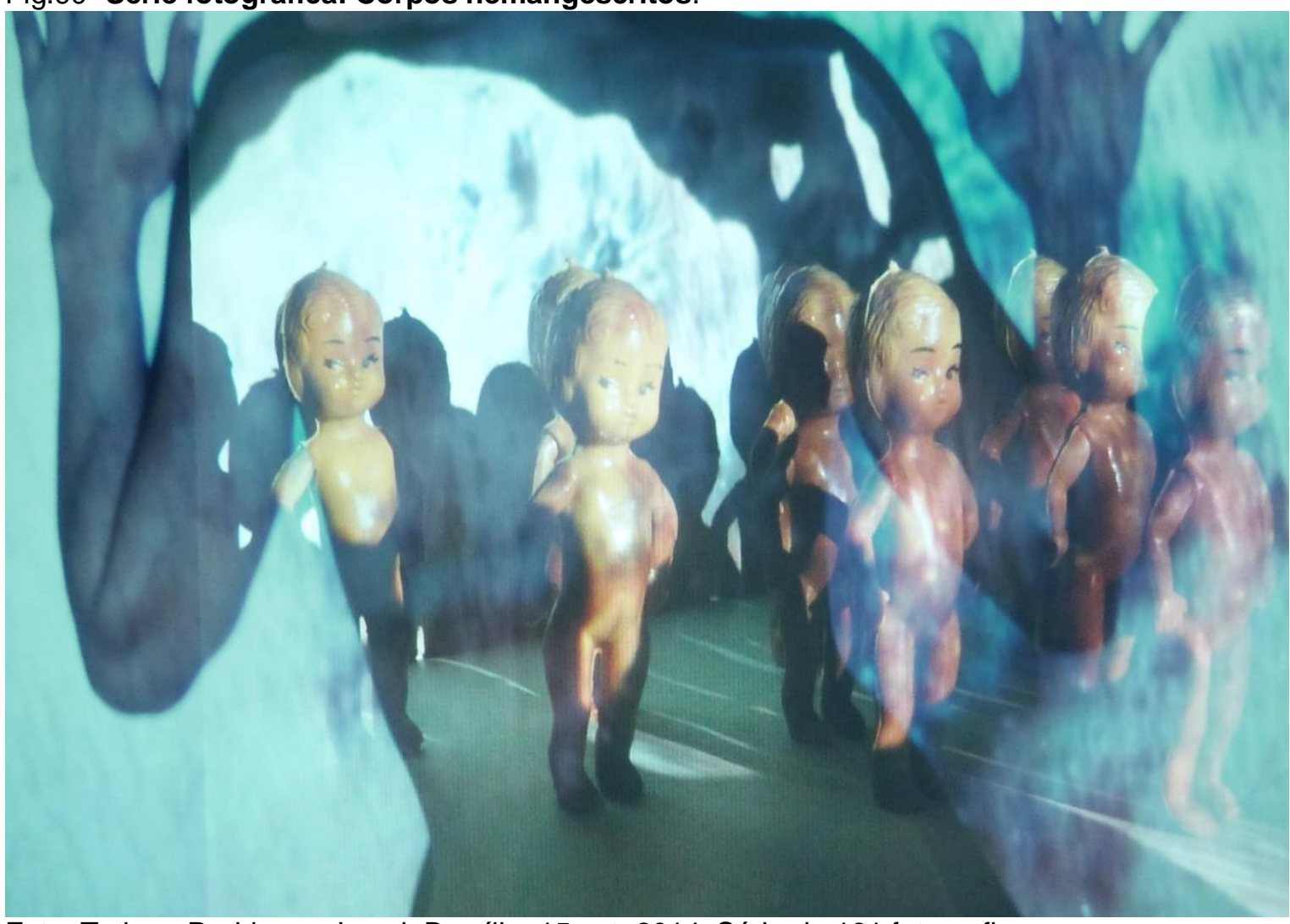

Foto: Tatiana Rodrigues. Local: Brasília, 15 set. 2014. Série de 161 fotografias.

\section{Fig.91- Série fotográfica: Corpos hemangescritos.}

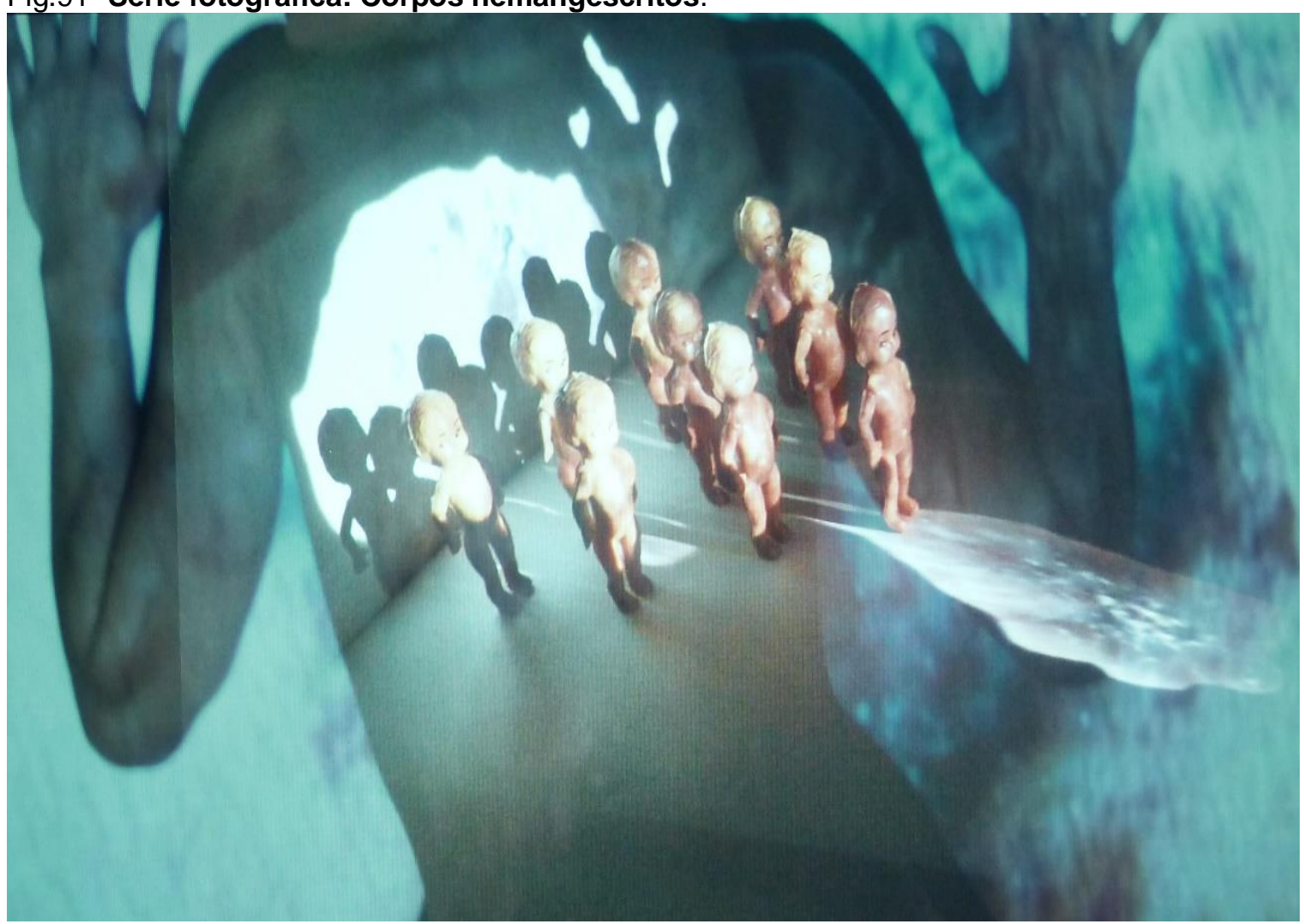

Foto: Tatiana Rodrigues. Local: Brasília, 15 set. 2014. Série de 161 fotografias. 
Fig.92- Série fotográfica: Corpos hemangescritos.

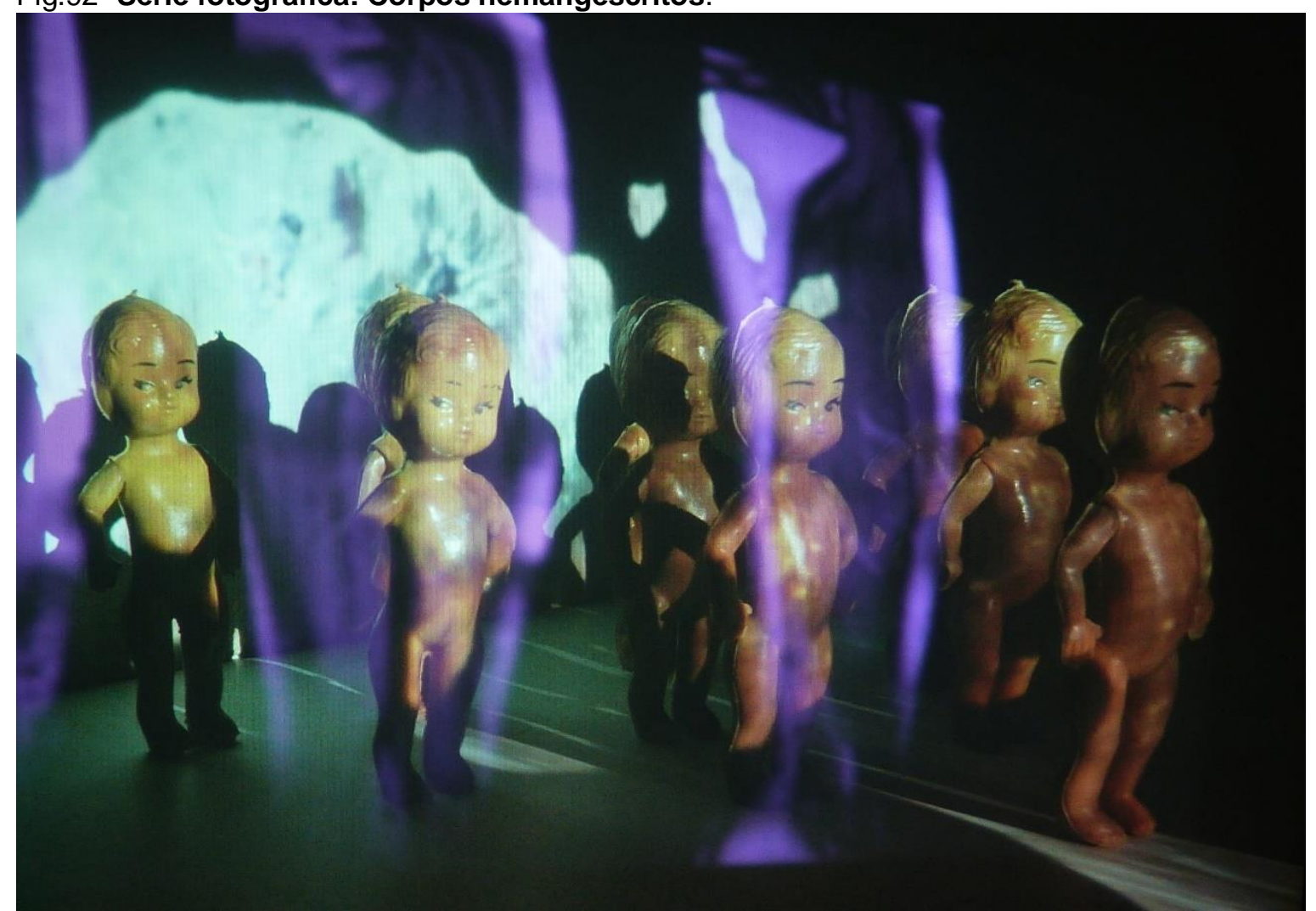

Foto: Tatiana Rodrigues. Local: Brasília, 15 set. 2014. Série de 161 fotografias.

Fig.93- Série fotográfica: Corpos hemangescritos.

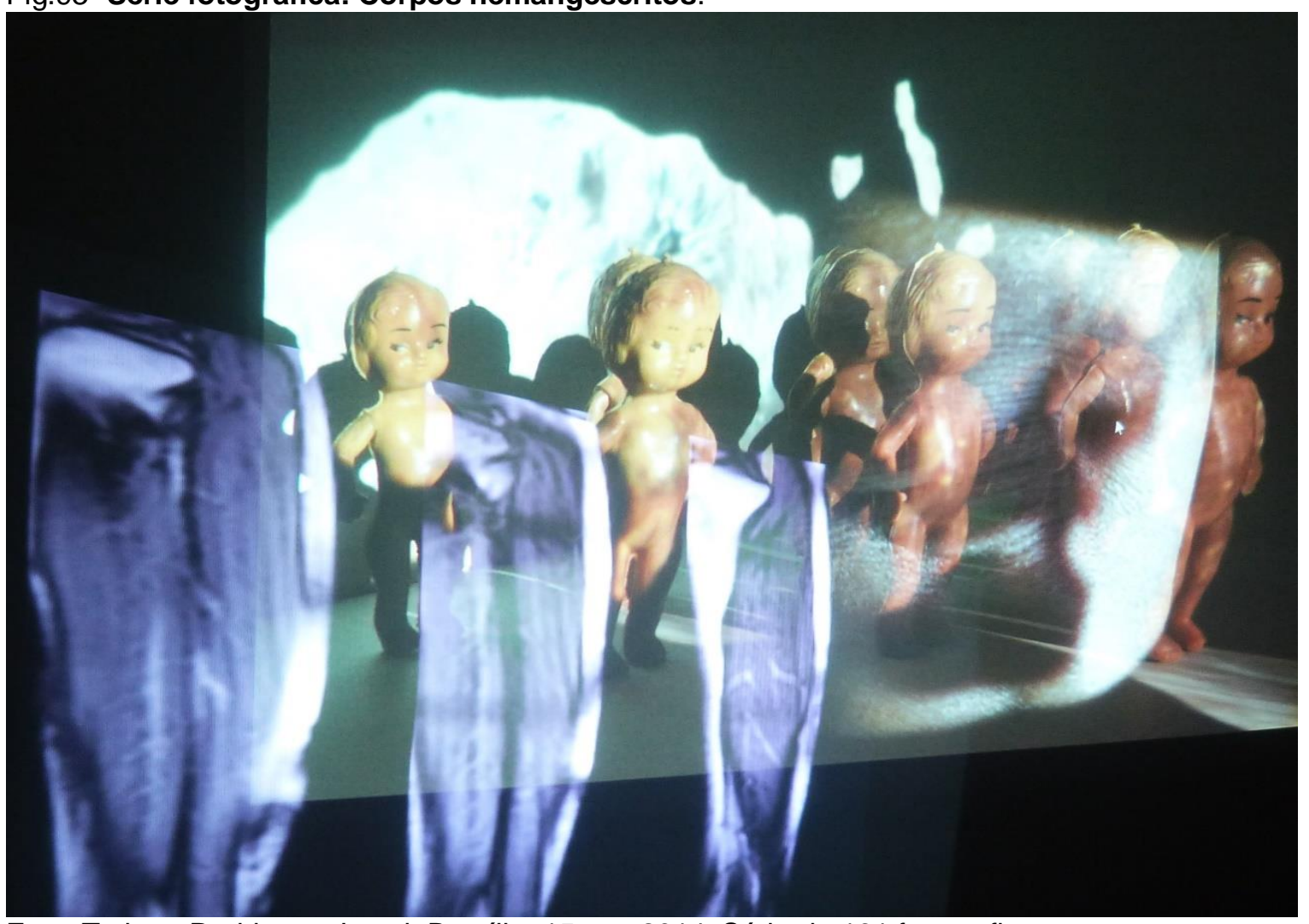

Foto: Tatiana Rodrigues. Local: Brasília, 15 set. 2014. Série de 161 fotografias. 
Fig.94- Série fotográfica: Corpos hemangescritos.

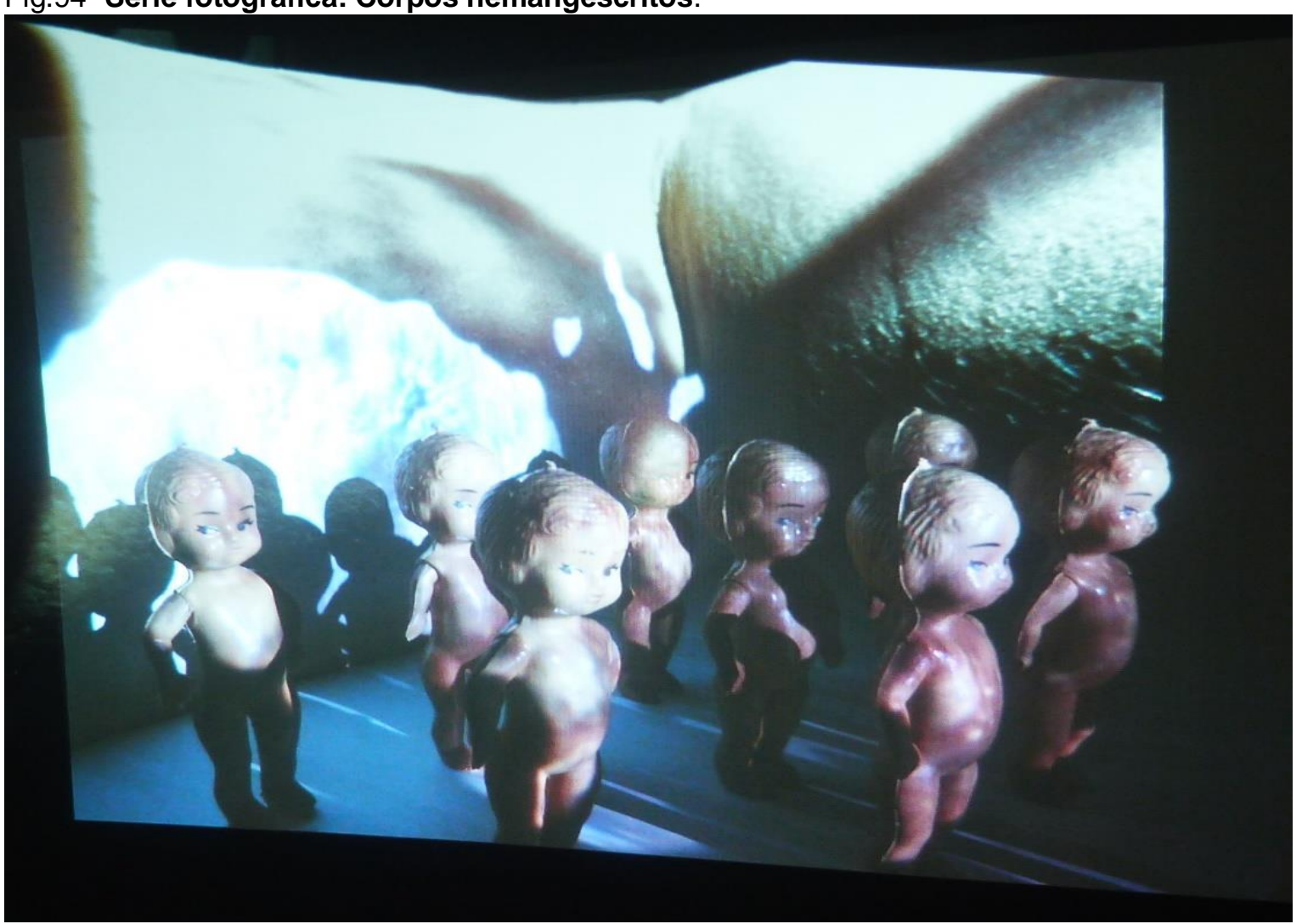

Foto: Tatiana Rodrigues. Local: Brasília, 15 set. 2014. Série de 161 fotografias.

Fig.95- Série fotográfica: Corpos hemangescritos.

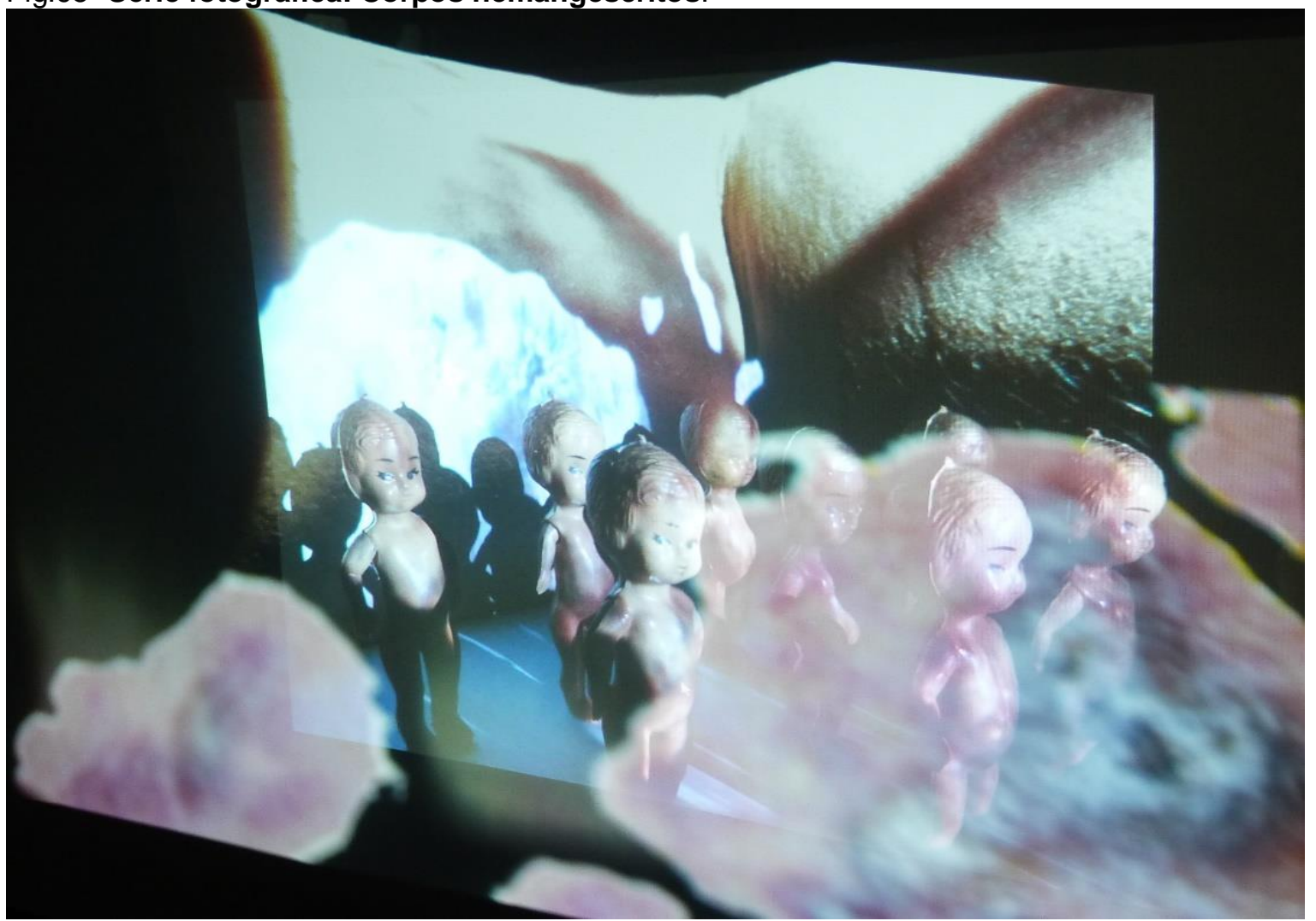

Foto: Tatiana Rodrigues. Local: Brasília, 15 set. 2014. Série de 161 fotografias. 
Fig.96- Série fotográfica: Corpos hemangescritos.

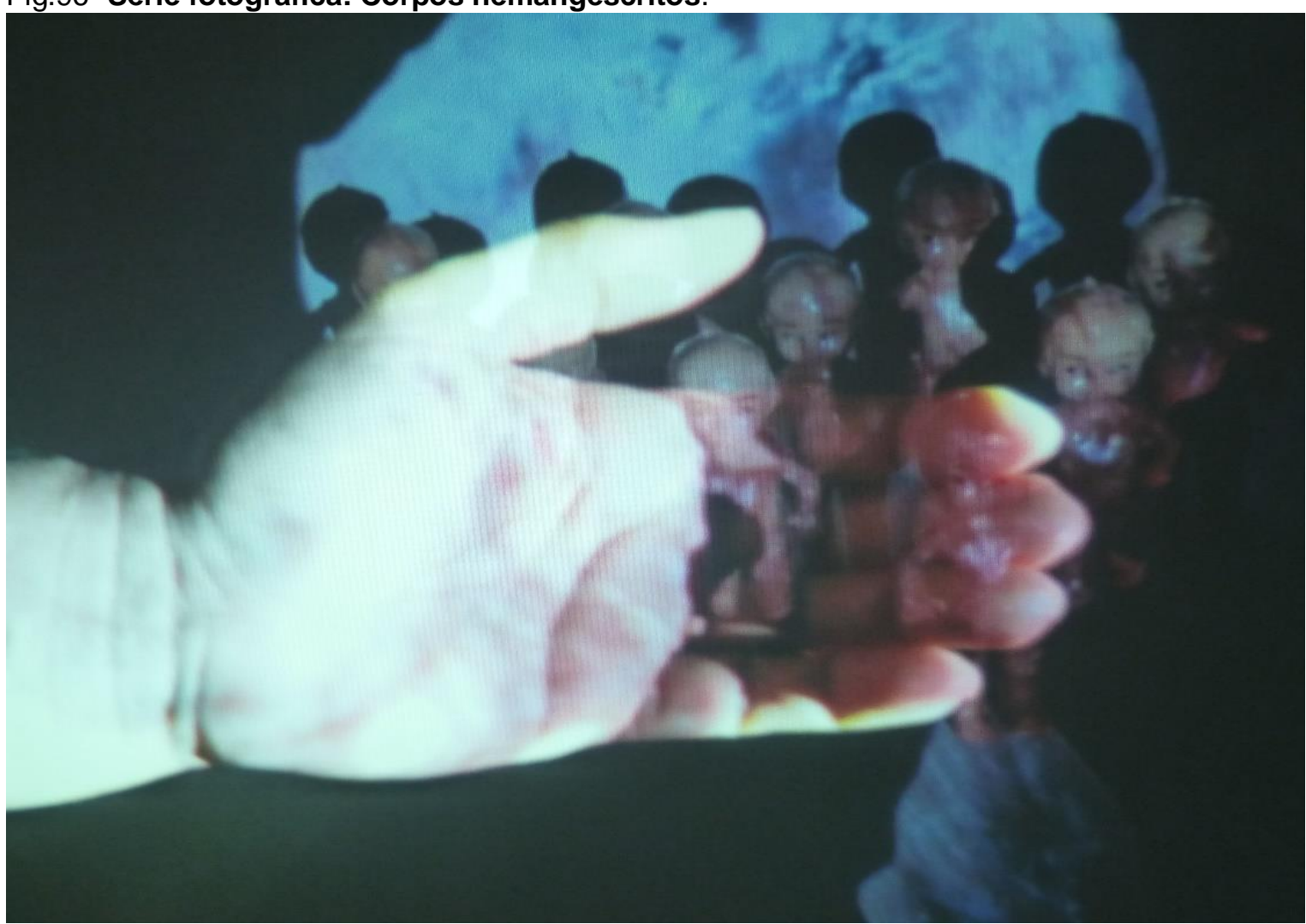

Foto: Tatiana Rodrigues. Local: Brasília, 15 set. 2014. Série de 161 fotografias.

Fig.97- Série fotográfica: Corpos hemangescritos.

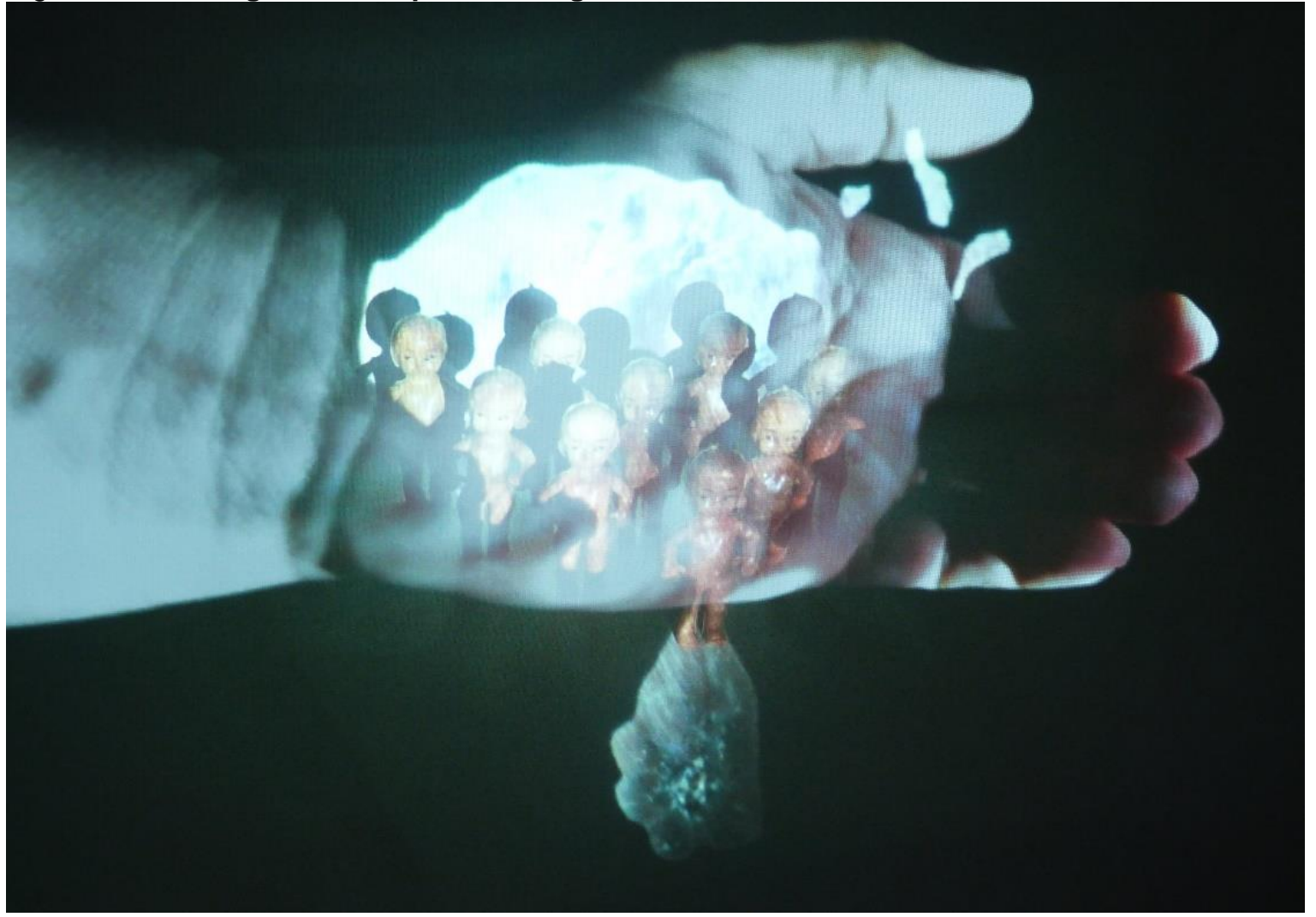

Foto: Tatiana Rodrigues. Local: Brasília, 15 set. 2014. Série de 161 fotografias. 
Fig.98- Série fotográfica: Corpos hemangescritos.

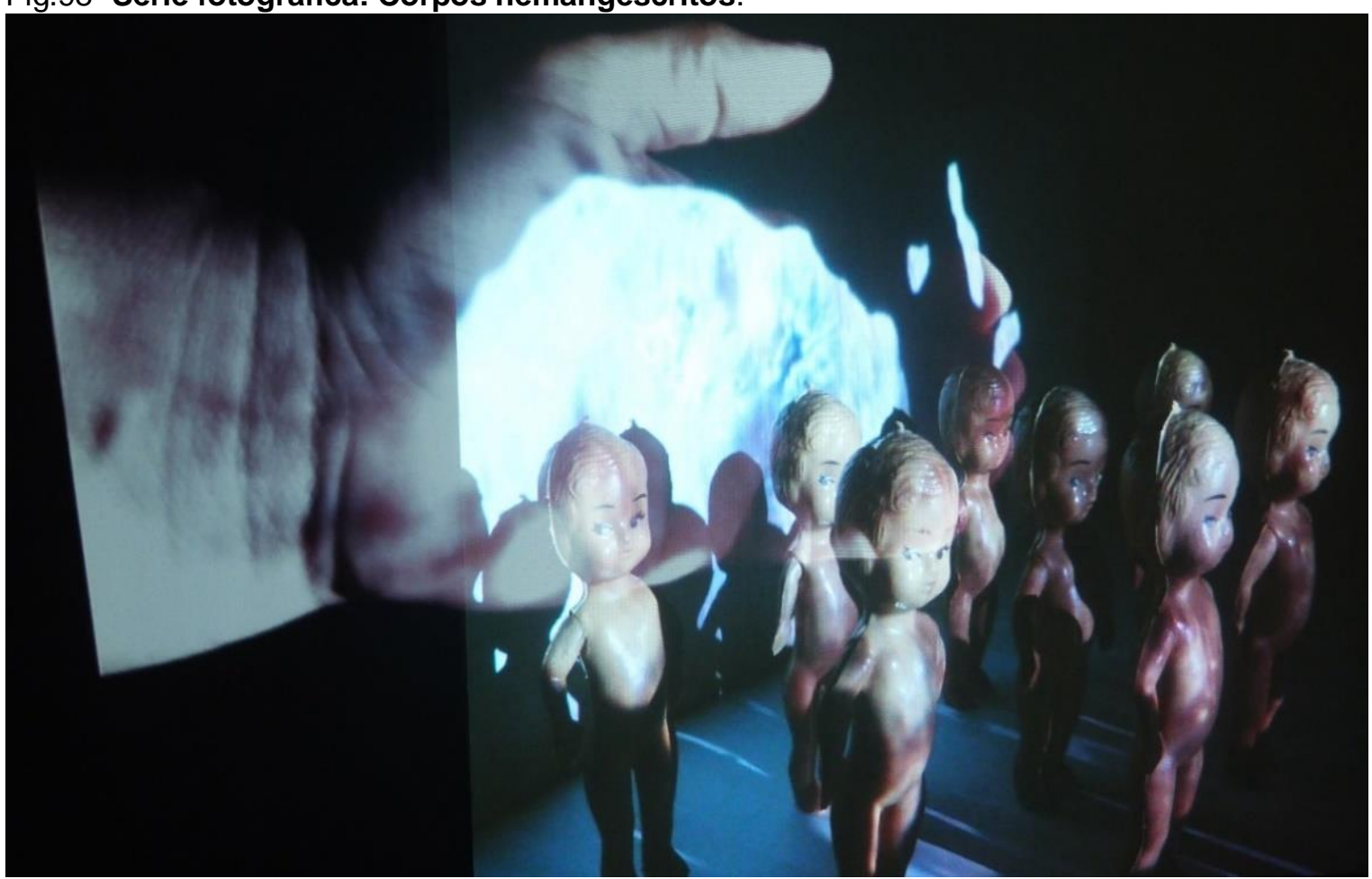

Foto: Tatiana Rodrigues. Local: Brasília, 15 set. 2014. Série de 161 fotografias.

Fig.99- Série fotográfica: Corpos hemangescritos.

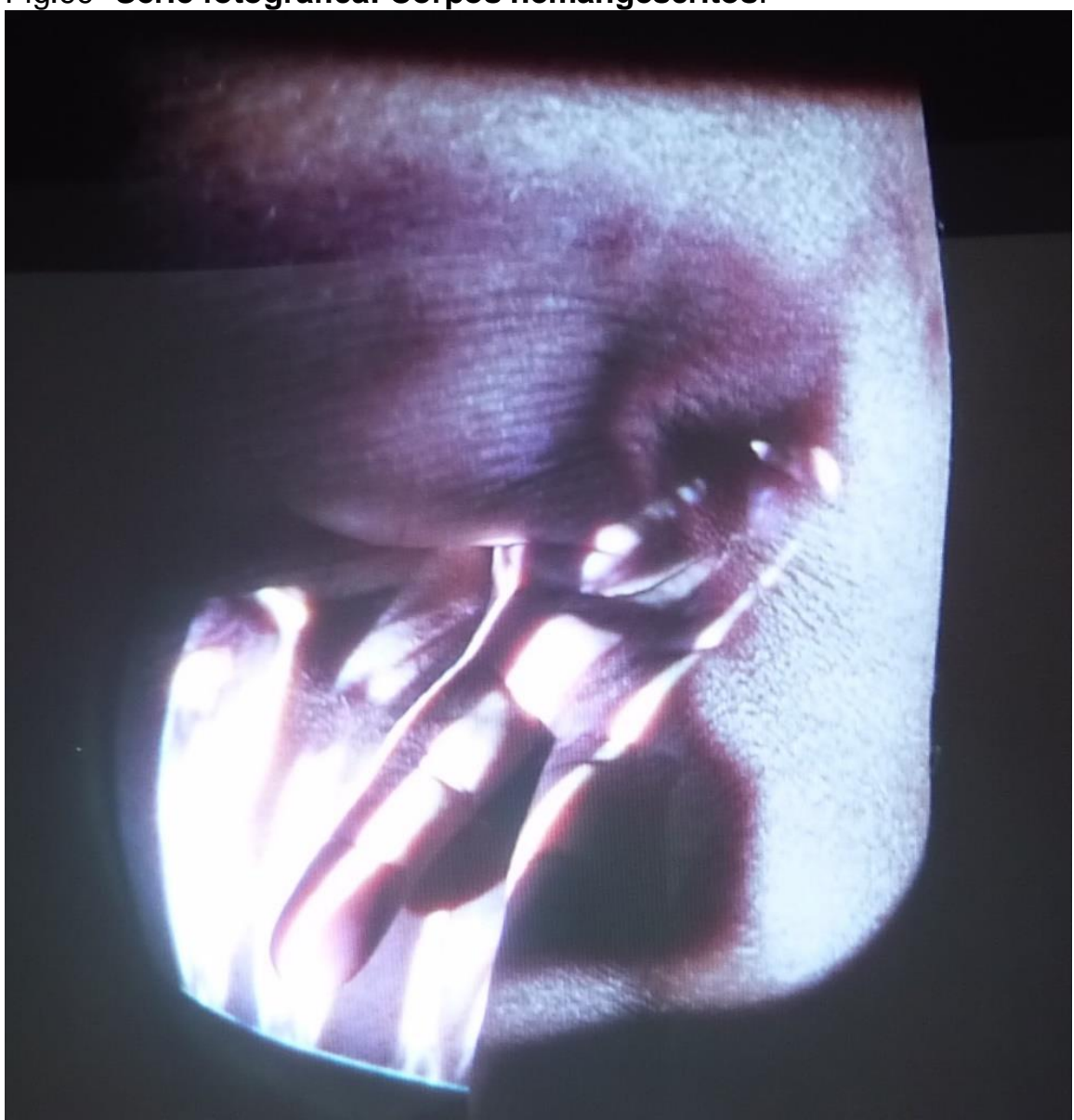

Foto: Tatiana Rodrigues. Local: Brasília, 15 set. 2014. Série de 161 fotografias. 
Fig.100- Série fotográfica: Corpos hemangescritos.

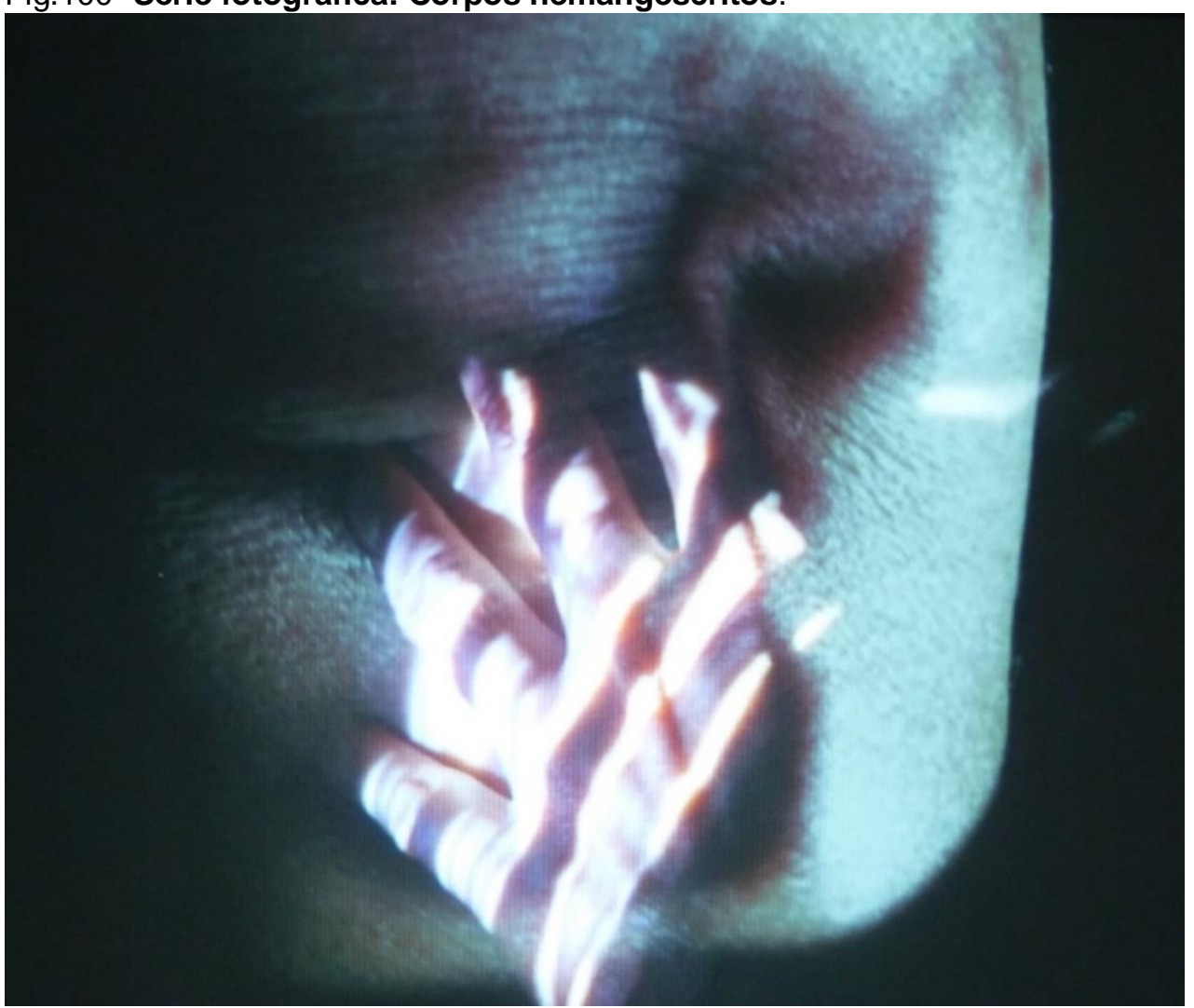

Foto: Tatiana Rodrigues. Local: Brasília, 15 set. 2014. Série de 161 fotografias.

Fig.101- Série fotográfica: Corpos hemangescritos.

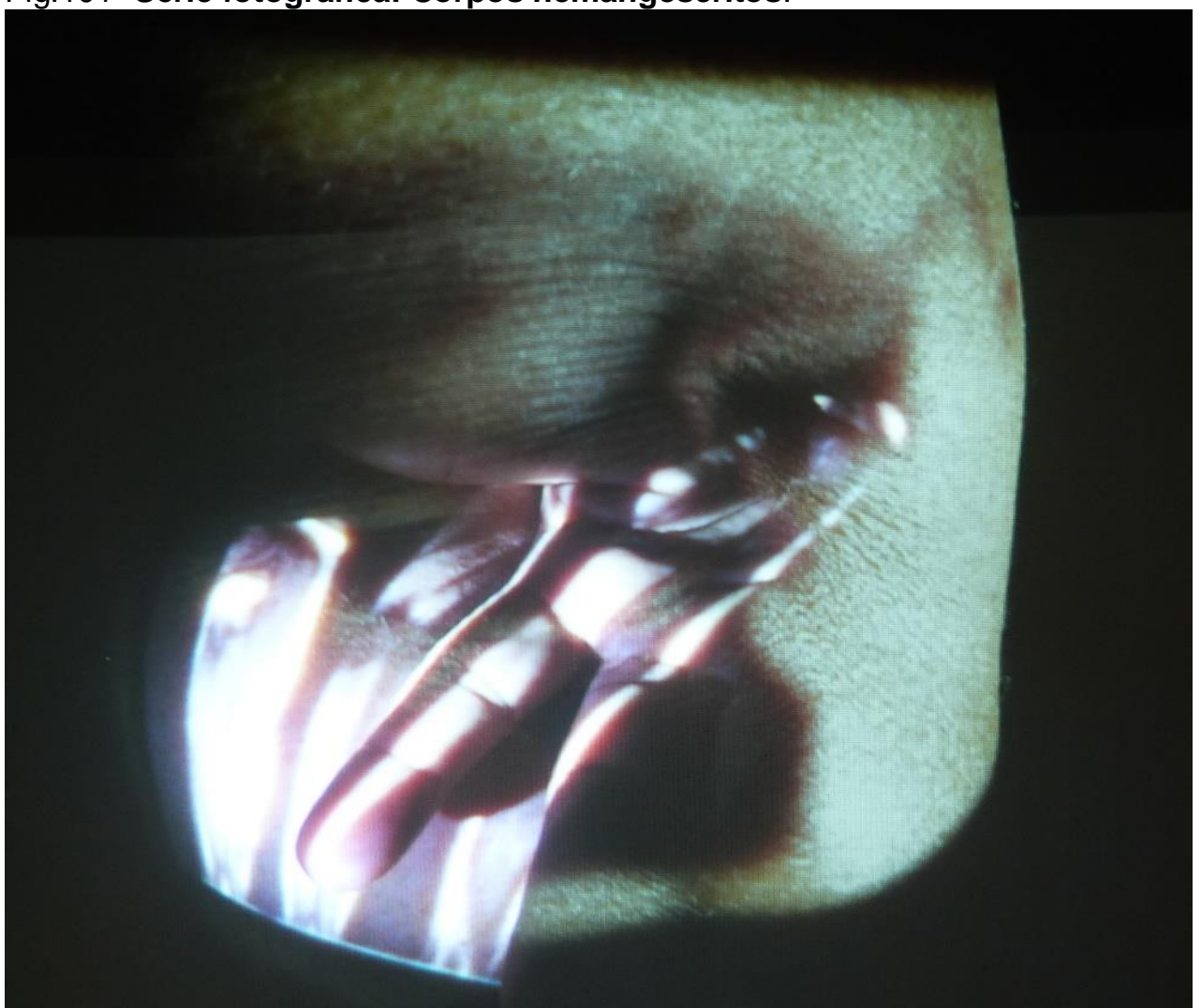

Foto: Tatiana Rodrigues. Local: Brasília, 15 set. 2014. Série de 161 fotografias. 
Fig.102- Série fotográfica: Corpos hemangescritos.

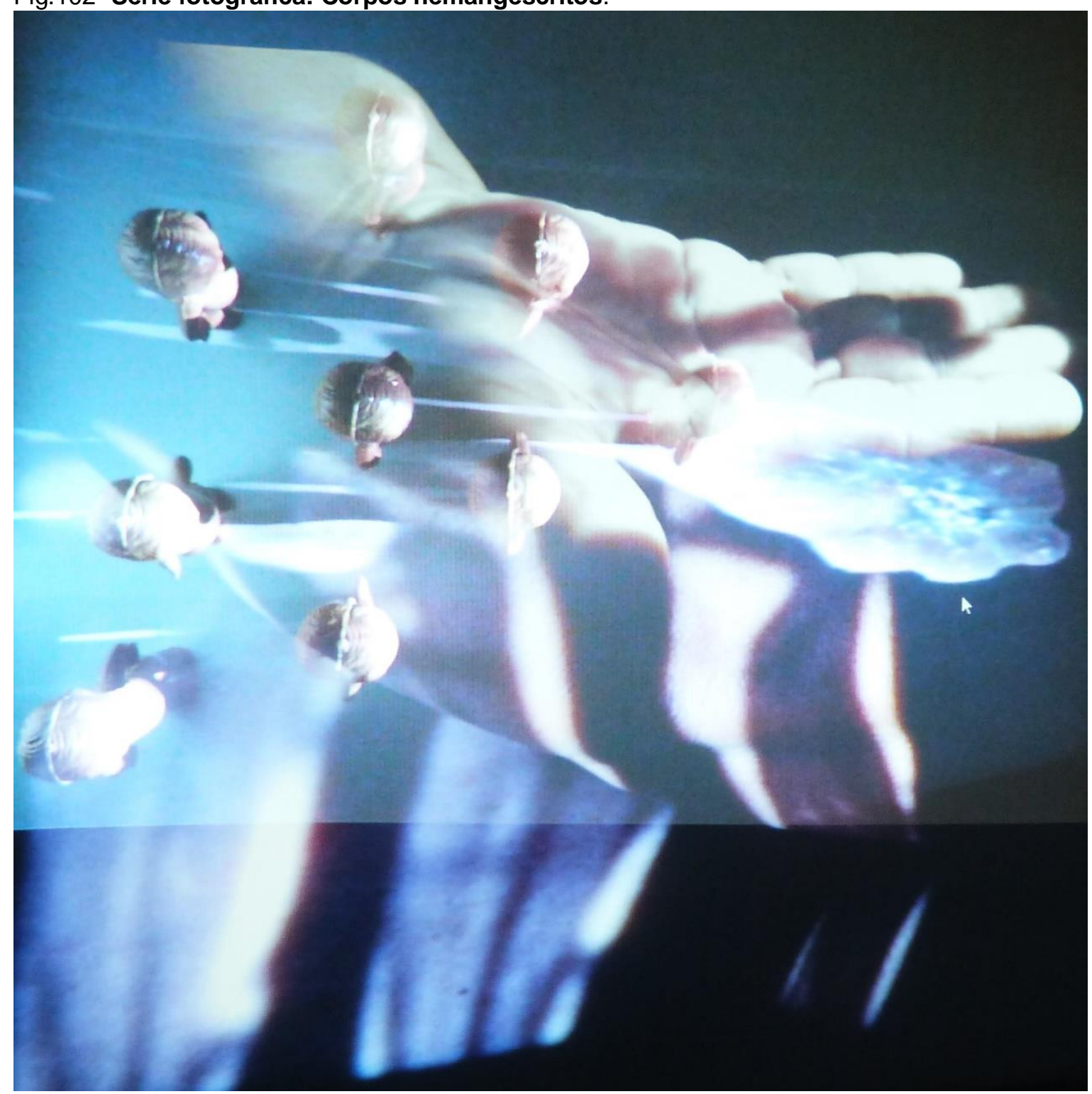

Foto: Tatiana Rodrigues. Local: Brasília, 15 set. 2014. Série de 161 fotografias. 
Fig.103- Série fotográfica: Corpos hemangescritos.

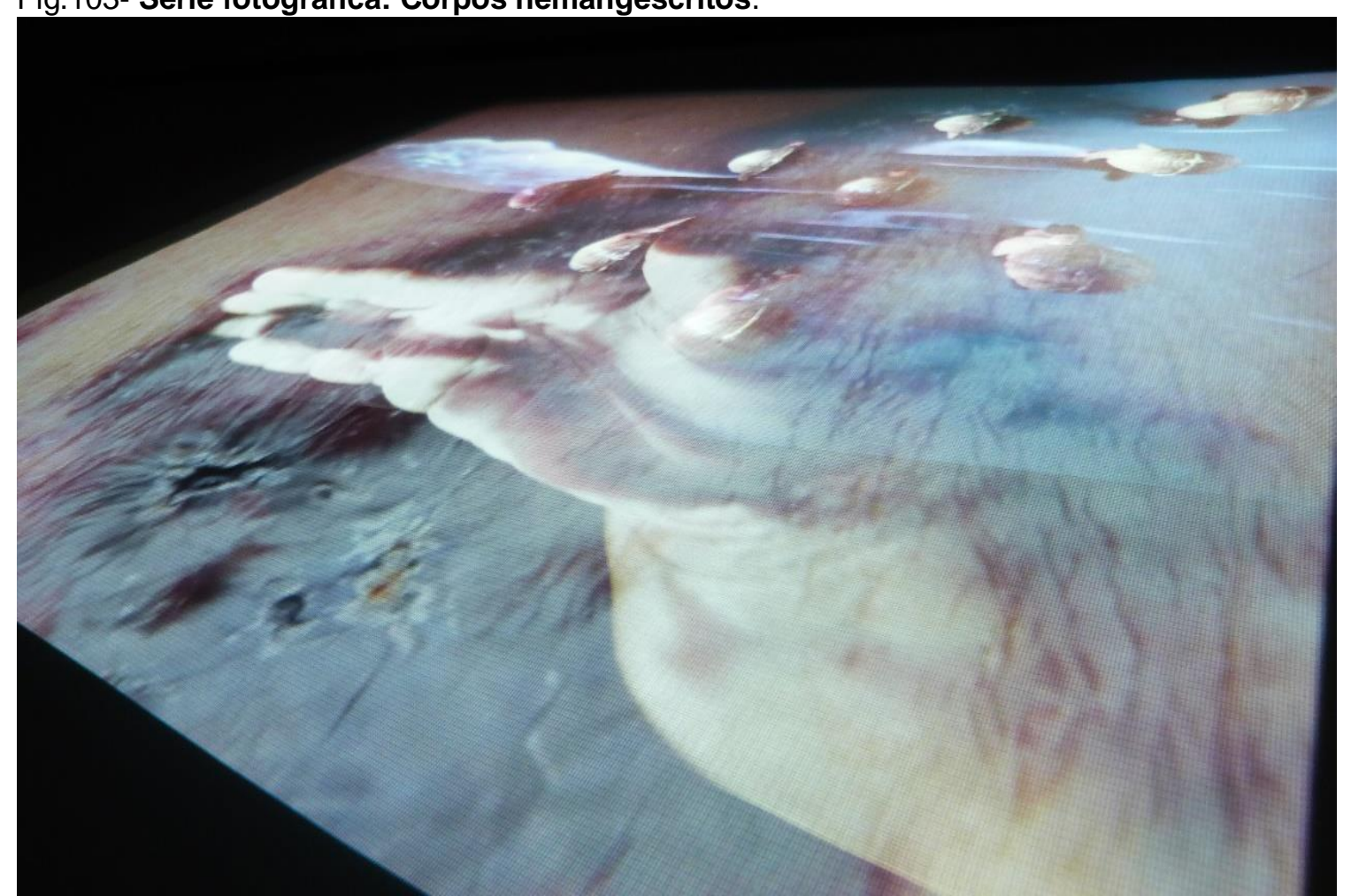

Foto: Tatiana Rodrigues. Local: Brasília, 15 set. 2014. Série de 161 fotografias.

Fig.104- Série fotográfica: Corpos hemangescritos.

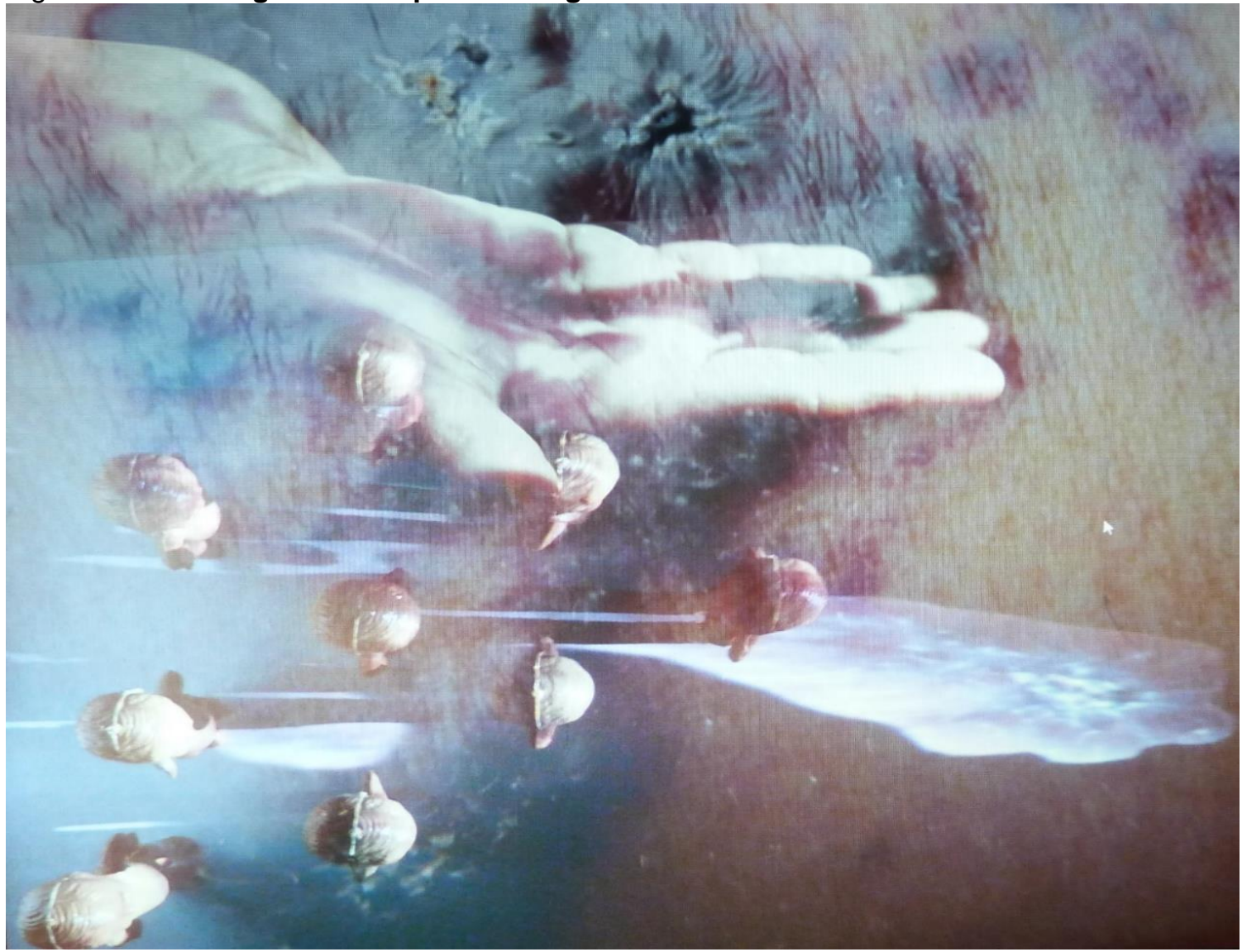

Foto: Tatiana Rodrigues. Local: Brasília, 15 set. 2014. Série de 161 fotografias. 


\subsection{Análise final das produções}

Ao disponibilizar seus recursos tecnológicos a favor das composições artísticas, as projeções e a fotografia podem ser consideradas os mediadores deste processo de produção. A fotografia atua como o fundamento da construção de toda a produção imagética e as projeções erguem-se como colunas de apoio às criações que envolvem o processo.

Por meio da projeção, as imagens foram submetidas a profundas intervenções em sua constituição. Por exemplo, as primeiras imagens dos hemangiomas (figs. 31,34 e 37) capturadas pela fotografia para este projeto foram consubstanciadas em projeções que, ao longo do processo, foram transfiguradas em um verdadeiro vir-aser nas séries fotográficas. A projeção também favoreceu o diálogo imagético entre as macroimpressões dos corpos envolvidos nas composições. Na produção denominada corpos hemangescritos, esse diálogo chega ao seu ápice com a convergência entre as macroimpressões artísticas.

O uso da fotografia favoreceu as composições visuais propostas ao longo deste processo criativo. A fotografia disponibiliza meios que transcendem os recursos tecnológicos uma vez que, por meio das composições artísticas, ela é capaz de expressar-se no campo emotivo.

A fotografia também desempenhou um papel de grande importância nas criações visuais, tendo em vista que ela é toda luz, um recurso extremamente poético: a incidência, a emanação, a captura, a integração entre as imagens, enfim, seu potencial compositivo. Assim, o diálogo entre os vários elementos fotográficos buscou aproximar o sujeito do objeto não apenas em busca de uma apreciação visual, mas em busca de uma iluminação da alma.

Sendo assim, lançando-se em novas experiências visuais, o resultado destas produções artísticas possibilitou que o sentir na fotografia pudesse emergir para 0 campo visual, favorecendo a construção de signos imagéticos que podem despertar novas percepções no receptor.

Dessa maneira, acredito que o olhar que acolhe as composições artísticas desenvolvidas nesta pesquisa foi estimulado a desvincular-se de um olhar exclusivamente observador, e voltar-se para uma espécie de interiorização do olhar. Essa expectativa deve-se ao fato de que o conteúdo extremamente poético envolvido nestas construções tenha instigado o espectador a voltar-se para o seu repertório individual 
e, assim, possa reflexionar a respeito da sua própria existência, identidade, aproximação e afastamento com o seu corpo e com o do outro. Logo, o receptor conseguirá abstrair as composições imagéticas de uma maneira que nenhum outro olhar jamais poderá captar, uma vez que ele enveredará por caminhos que sobrepujam o âmbito tecnológico. 


\section{CONSIDERAÇÕES FINAIS}

Por definição, uma dissertação de mestrado compõe-se de um diálogo silencioso entre teóricos que convidamos para construir um pensamento, a partir de uma espécie muito rica de agenciamentos. No campo da Arte, especificamente em Arte e tecnologia, muito mais do que agenciar conhecimentos, escrever uma dissertação é experimentar formas de expressão artística, refletir sobre elas e, por fim, propor um diálogo entre os diversos autores lidos e essa produção. Acreditamos ter atingido o objetivo de produzir uma dissertação de mestrado, cumprindo as exigências e expectativas necessárias à Arte.

Ao longo da trajetória de estudos que realizamos, podemos afirmar que a análise do conto 'A marca de nascença', a partir dos conflitos decorrentes de uma marca de nascença na protagonista, desempenhou um papel de grande importância para as reflexões a respeito da marca de nascença enquanto 'imperfeição do corpo'. Isso porque, por meio da ampliação dessa temática, o 'corpo marcado' passou a ser entendido como 'corpo singularizado' que traz consigo suas macroimpressões. Essa compreensão partiu da concepção de que, assim como as impressões digitais presentes nas polpas dos dedos de nossas mãos, as marcas de nascença trazem consigo características tão singulares que jamais poderão ser igualmente reproduzidas em outro corpo acometido.

A abordagem de Jeudy (2002) sobre a importância do papel exercido pelo olhar do outro trouxe a concepção da suscetibilidade do corpo em se enxergar de maneira diferente. Ainda, fundamentou a ideia de que as macroimpressões do corpo acometido podem assumir novas roupagens no campo das Artes, e que o corpo marcado, para nós, produz macroimpressões artísticas.

Nota-se que o senso comum determina que os objetos acolhidos no ambiente artístico são aqueles dotados de uma beleza coerente, ou, ainda, algo que transfira prazer imediato ao receptor. No entanto, à luz do conceito de estranhamento (Chklóvski, 1916 apud Ferrara, 2005, p.34), pudemos entender que o objeto representado, quando transpõe as convenções de representação usual para uma esfera de novas percepções, exatamente pela oposição deste objeto ao seu contexto habitual, pode despertar novas percepções e novos olhares. Dessa maneira, o hemangioma foi trabalhado nas produções artísticas, desvinculando-se do peso da rotina médica de 
maneira a despertar novas percepções no receptor que o perceberia sob a égide da estética, da catarse e, portanto, de modo poético.

As produções artísticas que foram construídas a partir do uso dos recursos fotográficos, projeção e convergência das projeções utilizaram uma metodologia impregnada de unicidade, uma vez que esta foi construída ao longo do processo criativo das produções. Esse percurso foi consolidado a partir do uso da projeção de imagens como o elemento mediador e criador de imagens poéticas. Logo, as imagens do hemangioma, desde a primeira fotografia até sua composição final, foram submetidas a um longo processo de transmutação imagética que a cada etapa compositiva de projeção e captura fotográfica reafirmava o seu potencial criativo. Outro resultado de grande relevância neste processo refere-se às perspectivas criativas do olhar do fotógrafo que, aliadas as peculiaridades dos corpos suporte, trouxeram o elemento "singularidade" para algumas das composições fotográficas.

Assim, pode-se afirmar que as construções fotográficas denominadas corpos hemangescritos fizeram uso de métodos precursores com o uso da projeção de imagens simultâneas a fim de obter a convergência entre as fotografias e possibilitar novas criações artísticas. As composições fotográficas obtidas a partir da interação entre as singularidades das imagens trouxeram ainda mais profundidade poética às produções. Por meio da luz dos projetores, a fusão entre as macroimpressões dos corpos deu origem às macroimpressões artísticas. Nesse sentido, pode-se afirmar que o grande mérito do processo metodológico desenvolvido neste estudo provém do fato de que os procedimentos das produções percorreram caminhos repletos de potencialidades de significação, composição e interpretação. O método revelou-se como um procedimento artístico adequado uma vez que um processo pode sempre ser reengendrado em novos ciclos em um contínuo vir-a-ser.

De maneira conclusiva, nota-se que as experimentações desenvolvidas ao longo desta pesquisa contribuíram para reafirmar a viabilidade de construções artísticas a partir da marca de nascença hemangioma, o corpus deste trabalho. Isso devese à percepção de que a vida do artista, bem como suas singularidades, podem contribuir em suas criações. Assim, meus hemangiomas foram impulsionados a atravessar a fronteira da abordagem médica e percorrer um caminho investigativo rumo a sua incorporação às linguagens artísticas e poéticas que produziram os corpos hemangescritos. Esta criação fotográfica foi concebida a partir da concepção poética de que os corpos-suporte, "escritos" pelo hemangioma nas séries fotográficas anteriores, se 
fundem e tornam-se corpos hemangescritos pela luz. A partir da descrição poética da obra, entende-se que, por meio da interação das luzes das projeções, o hemangioma constituído de luz foi propagado por meio de suas mutações nas sobreposições das camadas translúcidas das luzes que construiu todo o processo artístico e poético das criações ao qual o receptor pode aventurar-se a perceber o punctum ${ }^{79}$ nas fotografias. Afirmamos isso, pois o objetivo das experimentações metodológicas, artísticas e poéticas que constituíram os corpos hemangescritos é que essas obras possam despertar novas percepções no receptor rumo a um "novo olhar".

${ }^{79}$ BARTHES ,1984, p.46. 


\section{REFERÊNCIAS BIBLIOGRÁFICAS}

BACHELARD, Gaston. A poética do espaço. 6" tiragem. Ed. São Paulo: Martins Fontes, 2003.

BARTHES, Roland. A câmera clara: nota sobre a fotografia. Roland Barthes; tradução de Júlio Castañon Guimarães. -Rio de Janeiro: Nova fronteira, 1984.

BLANCHOT, Maurice. O livro por vir. In: O livro por vir. Maurice Blanchot; tradução Leyla Perrone-Moisés. -2. Ed. -São Paulo: Editora WMF Martins Fontes, 2013. - (Coleção biblioteca do pensamento moderno). p.327-359.

BEZERRA, Armando José China. As belas Artes da medicina. - Brasília: Conselho Regional de Medicina do DF, 2003.

DAWKINS, Richard, 1941. A escalada do monte improvável. Richard Dawkins; tradução Suzana Sturlini Couto. -São Paulo: Companhia das Letras, 1998.

DUBOIS, Philippe. 0 ato fotográfico e outros ensaios. Philippe Dubois; tradução Marina Appenzeller. - 14ª Ed. - Campinas, SP: Papirus, 2012. - (Série Oficio de Arte e Forma).

FABRIS, Annateresa. Fotografia: usos e funções no século XIX. Annateresa Fabris (org.) - 2 ed. 1 reimpr. - São Paulo: Editora da Universidade de São Paulo, 2008. (Texto \& Arte, 3).

FERRARA, Lucrécia. A estratégia dos signos. São Paulo: Perspectiva, 2005.

FERREIRA, Glória e COTRIM, Cecilia. Escritos de artistas: anos 60/70. Glória Ferreira e Cecilia Cotrim (seleção e comentários); [tradução de Pedro süssekind...et al.]. - Rio de Janeiro: Jorge Zahar Ed., 2006.

HAWTHORNE, Nathaniel. The Birthmark. In: Mosses From An Old Manse and Other Stories. Printed in Great Britain by Amazon.co.uk, Ltd., Marston Gate. ISBN 9781496082220, 2014, p.1-10.

HAWTHORNE, Nathaniel. Os melhores contos de Nathaniel Hawthorne. Fernando Correia da Silva (prefácio); [seleção e tradução de Olívia Krähenbühl].-São Paulo: Círculo do Livro S.A., 1992.

ILHARCO, Fernando Albano. Equilíbrio Biológico de Afídeos. Edição Fundação Calouste Gulbenkian, Lisboa, 1992.

JEUDY, Henri-Pierre. O corpo como objeto de Arte. Tradução Tereza Lourenço. $2^{a}$ Ed._São Paulo: Estação Liberdade, 2002.

KRAUSS, Rosalind E. Caminhos da Escultura Moderna. Trad. Júlio Fisher. $2^{\underline{a}}$ ed. São Paulo: Martins Fontes, 2007. 
LOPES, Antônio Carlos. Diagnóstico e tratamento, volume 2. Antônio Carlos Lopes (Editor). Barueri, SP: Manole, 2006. Vários coordenadores. Vários colaboradores. Obra em 3 v.

ORTEGA Y GASSET, José. A desumanização da Arte. José Ortega y Gasset (18831955); tradução de Ricardo Araújo; revisão técnica da tradução Vicente Cechelero. 2.ed. - São Paulo: Cortez,1999. (Biblioteca da educação. Série 7. Arte e Cultura; v.2).

PELBART, Peter Pál. O corpo do Informe. In: Vida Capital-Ensaios de biopolítica. Ed. Iluminuras Ltda. São Paulo-SP, 2003, p.42-51.

PIRES, Beatriz Ferreira. O corpo como suporte da Arte. São Paulo: Senac, 2005.

PLAZA, Júlio. Arte e interatividade: autor-obra-recepção. Virtual Books, 2003. <http://www.iar.unicamp.br/disciplinas/ap858/AXILA/pagjulioplaza.html> Acesso em: 20 jun. 2012. 20:20:18.

RIBAS, João B. Cintra. O que são pessoas deficientes. Editora Brasiliense S.A., 1994.

SANTAELLA, L. Cultura e arte do pós-humano: da cultura das mídias à cibercultura. 3.ed. São Paulo: Paulus, 2008.

SERRA, Adriana Maria da Silva. Abordagem terapêutica dos Hemangiomas na Infância. 2007.115f. Dissertação (Mestrado em Ciências da Saúde) - Universidade de Brasília- Brasília, 2007.

ZAMBONI, Silvio. A pesquisa em Arte: um paralelo entre arte e ciência. Silvio Zamboni $-3^{\mathrm{a}}$ ed. rev. - Campinas, SP: Autores Associados, 2006.

\section{SITES CONSULTADOS (Web):}

<www.abraphel.org.br>. Acesso em: 10 maio 2012. 22:05:02.

<http://www.heloisacampos.com.br/website>. Acesso em: 10 maio 2012. 23:15:20.

<http://www.iar.unicamp.br/disciplinas/ap858/AXILA/pagjulioplaza.html>. Acesso em: 27 maio 2012.19:17:05.

<http://www.jornalciencia.com/saude/beleza/2324-os-mitos-e-os-misticismos-bizarros-por-tras-das-marcas-de-nascenca>. Acesso: 07 mar. 2013. 22:10:11.

$<$ http://vilamundo.org.br/2011/05/coletiva-na-galeria-mezanino-traz-retratos-e-autorretratos/>. Acesso:10 jul. 2013.18:22:10.

<http://2.bp.blogspot.com/_R8LkKSvcN4c/TKCLXFkPpgl/AAAAAAAAXwg/ TKpQ9LbNN6g/s400/>. Acesso: 10 jul. 2013.19:25:52. 
<http://sambrinegarcompii.files.wordpress.com/2013/01/becky-birthmark2.png> Acesso em: 10 jul. 2013.19:45:30.

<http://propagandasdegibi.wordpress.com/2012/05/27/boneca-angelica-1989/>. Acesso em: 07 mar. 2014.18:10:30.

$<$ http://m.mdemulher.abril.com.br/tv-novelas-famosos/famosos-seus-bonecos759623 >. Acesso em: 26 mar. 2014.18:25:55.

$<$ http://www.infopedia.pt/\$figura-reclinada-de-henry-moore>. Acesso em: 26 mar. 2014. 20:32:24.

<http://i1.r7.com/data/files/2C92/94A3/2560/828C/0125/7369/1666/6C01/bezerro-m20091209.jpg >. Acesso em: 26 mar. 2014. 23:08:55.

<http://canadianawareness.org/wp-content/uploads/2012/11/gorbachev.jpg >. Acesso em: 26 mar. 2014.18:30:24.

<http://arcadenoe.sapo.pt/img/album/88/424788_sou_o_dalmata_diferente_img.jpg>. Acesso: 26 mar. 2014. 23:15:38.

<http://www.fotoswiki.org/foto/duas-girafas-jpg>. Acesso em: 26 mar. 2014. 23:20:15.

<http://g1.globo.com/pr/oeste-sudoeste/noticia/2014/03/bebes-de-plastico-feitos-porartista-tem-veias-e-ate-marcas-de-nascenca.html>. Acesso em : 22 abril 2014. 21:25:30.

<http://www.yasni.info/ext.php?url=http\%3A\%2F\%2Fcatalogodasartes.com.br>. Acesso em: 22 abril 2014. 21:40:18.

<http://cargocollective.com/eduardosancinetti/Vermelho-e-Verde>. Acesso em: 22 abril 2014. 23:28:24.

<http://multissenso.blogspot.com.br/2009/11/lygia-clark-casa-e-o-corpo-labirinto.html>. Acesso em: 22 abril 2014. 22:40:57.

<http://www.architetturadipietra.it/wp/?p=1977>. Acesso em: 23 abril 2014. 20:38:27. <http://www.davisayer.com>. Acesso em: 26 abril 2014. 23:05:18.

$<h t t p: / / w w w . d a v i s a y e r . c o m / \# a=0 \& a t=0 \& m i=2 \& p t=1 \& p i=10000 \& s=0 \& p=5>$. Acesso em: 26 abril 2014. 23:23:11.

$<$ http://www.dx.com/p/telstar-mp50-mini-projector-w-hdmi-for-iphone-samsung-htcwhite-172789\#> Acesso em:13 agosto 2014. 23:18:20.

<http://www.wikiart.org/en/frida-kahlo/henry-ford-hospital-the-flying-bed-1932\#close> Acesso em: 08 set 2014. 22:50:35. 


\section{CD-ROM}

HOUAISS, Antônio, Mauro Vilar. Dicionário Eletrônico Houaiss da Língua Portuguesa 3.0. Instituto Antônio Houaiss de Lexicografia e Bancos de Dados da Língua Portuguesa S/C Ltda., Rio de Janeiro: Editora Objetiva, 2009.

\section{REVISTA}

DUARTE, Flávia. Cicatrizes difíceis de curar. In: Revista do correio-Marcas de Superação. Correio Brasiliense. Brasília, $1^{\circ}$ de Maio de 2011, ano 6, n.311, p. 22-29. 


\section{BIBLIOGRAFIA CONSULTADA}

ARNHEIM, Rudolf. Intuição e Intelecto na Arte. São Paulo: Martins Fontes, 1989.

BACHELARD, Gaston. A água e os sonhos: ensaio sobre a imaginação da matéria. Tradução Antônio de Pádua Danesi. São Paulo: Martins Fontes, 1989.

CORTANZE, Gérard de. Frida Kahlo: la belleza terrible. Gérard de Cortanze; adapatado por Núbia Petit Fontseré. -1a ed. 2a reimp. -Buenos Aires: Paidós, 2014.

GREINER, Christine. O corpo: pistas para estudos indisciplinares. -São Paulo: Annablume, 2005.

GARDNER, Howard. As artes e o desenvolvimento humano: um estudo psicológico artístico. Howard Gardner; tradução Maria Adriana Veríssimo VeronesePorto Alegre: Artes Médicas, 1997.

HAUSER, Arnold. História social da arte e da literatura. Editora Martins Fontes. São Paulo, 2003.

LACROIX, Michel. O culto da emoção. Michel Lacroix; tradução Vera Ribeiro. -Rio de Janeiro: José Olympio, 2006.

LE BRETON, David. Antropologia do corpo e modernidade. David Le Breton; tradução de Fábio dos Santos Creder. Lopes. -Petrópolis, RJ: Vozes, 2011.

KAFKA, Franz. A metamorphose; Um artista de fome; Carta ao pai. Franz Kafka; tradução Torrieri Guimarães. -3. ed. - São Paulo: Martin Claret, 2012. -Coleção a obra-prima de cada autor; 21.

KRAUSS, Rosalind. O fotográfico. Título original: Le Photographique. Pour une Théorie dês Ecarts. Publicado originalmente por Editions Macula, Paris, em 1990. Tradução de Anne Marie Davée, 1ª edição, 3ª impressão, 2012.

MEDEIROS, Maria Beatriz de; PUGLIESE, Vera (org.) CoMA: Coletivo do Mestrado em Arte. Brasília, DF: Programa de Pós-Graduação do Instituto de Artes/ UnB, 2004.

. (org.) Arte em pesquisa: especificidades. Curadoria;

História, Teoria e Crítica da Arte; Questões do Corpo e da Cena; Restauro e Conservação de Materiais. ANPAP-Brasília: DF.: Editora da Pós-graduação em Arte da Universidade de Brasília, 2004. v.1.

(org.) Arte em pesquisa: especificidades. Ensino e Aprendizagem da Arte; Linguagem Visuais. ANPAP-Brasília: DF.: Editora da Pós-graduação em Arte da Universidade de Brasília, 2004. v.2.

MELLO, Maria Teresa Villela Bandeira de. Arte e fotografia: o movimento pictorialista no Brasil. Maria Teresa Villela Bandeira de Mello. -Rio de Janeiro: Funarte, 1998. 
MERLEAU-PONTY, Maurice. Fenomenologia da Percepção. São Paulo, Martins Fontes, 1994.

NOVAES, Adauto. O olhar. Adauto Novaes (Organização). -4a reimpressão -São Paulo: Companhia das Letras, 1993.

PLAZA, Julio e Tavares, Monica. Processos Criativos com Meios Eletrônicos: Poéticas Digitais. São Paulo, Editora Hucitec, 1998.

SANTOS, Albertina Brasil (Coord.). Estratégias e Orientações sobre artes: respondendo com Arte às necessidades especiais. MEC/ SEE: Brasília, Dezembro 2002. Apoio: Funarte, FNDE/MEC.

SCHILDER, Paul. A imagem do corpo. Paul Schilder; tradução Rosanne Wertman. -São Paulo: Martins Fontes, 1980.

TORMANN, Jamile. Caderno de lluminação: arte e ciência. - 2 ed. ver. e ampl. Rio de Janeiro: Música Tecnologia, 2008.

WÖLFFLIN, Heinrich. Conceitos fundamentais da História da arte. Editora Martins Fontes.-São Paulo, 1999. 
ANEXO 


\section{PORTFÓLIO}

Nota-se que o corpus desta pesquisa, assim como as experimentações propostas nesta dissertação, foram surgindo a partir dos recortes dos temas trabalhados ao longo das produções artísticas da minha trajetória como artista.

Dos projetos desenvolvidos durante minhas graduações em Artes plásticas e Artes cênicas (UnB), o nascimento foi um dos temas mais recorrentes, assim como as abordagens pertinentes à concepção humana que favoreceu tanto os estudos conceituais quanto a elaboração de obras artísticas.

Mutilações Fetais (2004) abordou a temática das malformações ou deformidades intrauterinas que acometem inúmeras crianças em seus mais diferentes graus de comprometimento. $O$ trabalho também trouxe reflexões a respeito das deformidades causadas nos fetos acometidos por aborto. O tratamento poético dado ao tema objetivou evocar sentidos e sensações sobre questões como a deformidade, a mutilação, a modificação e/ou acometimento por doenças e/ou situações adversas vivenciadas pelo corpo fetal.

Fig.105- Mutilações Fetais.
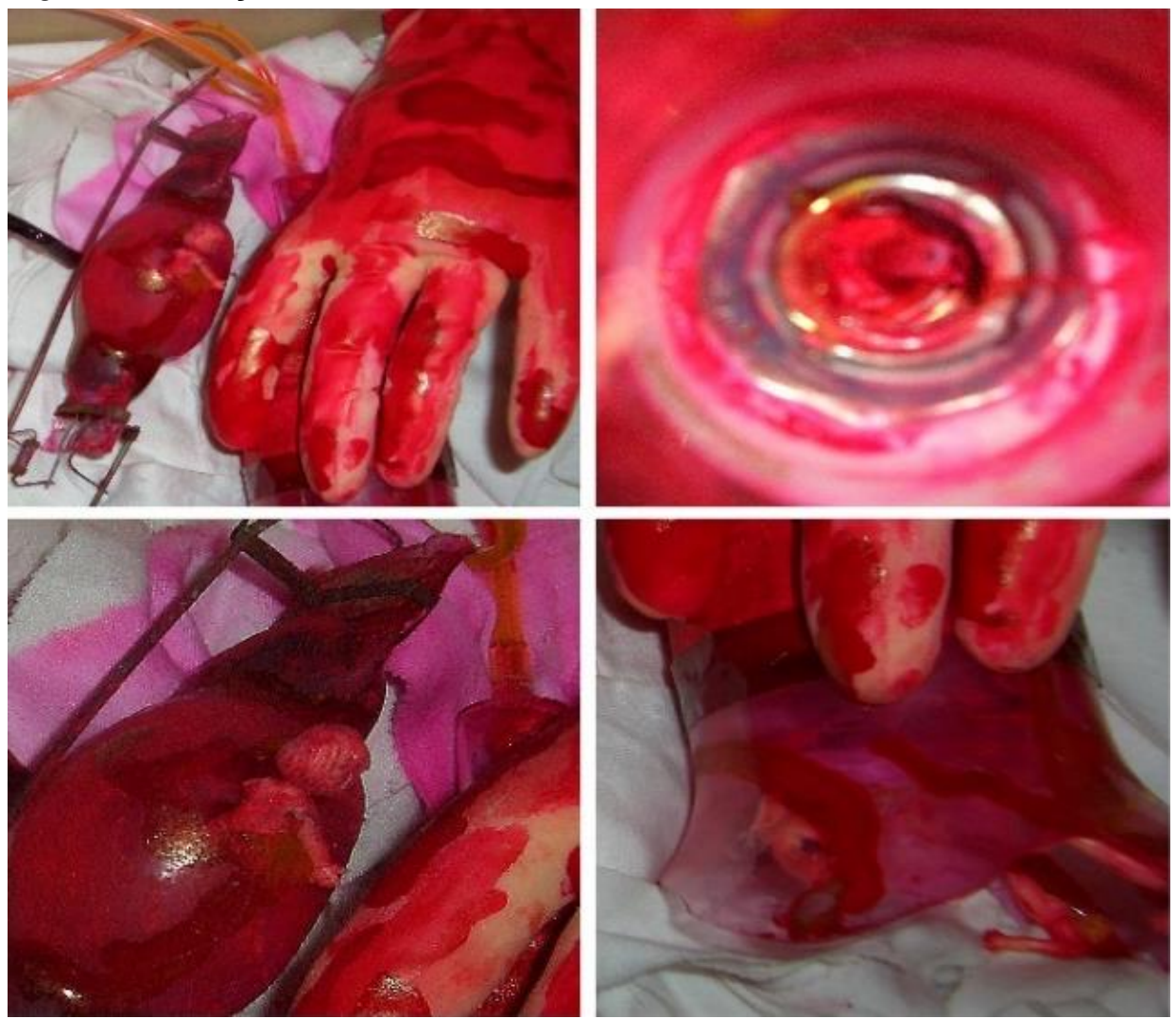

Obra e Foto: Tatiana Rodrigues, 2004. 
A obra Duo Corpos (2006) surgiu a partir do estudo do tema Corpo. Após a escolha da obra Figura Reclinada do artista Henri Moore (1938), a composição artística foi planejada com técnicas de estilização de traços e formas, bem como, exercícios de releitura.

Fig. 106- Figura reclinada ${ }^{80}$

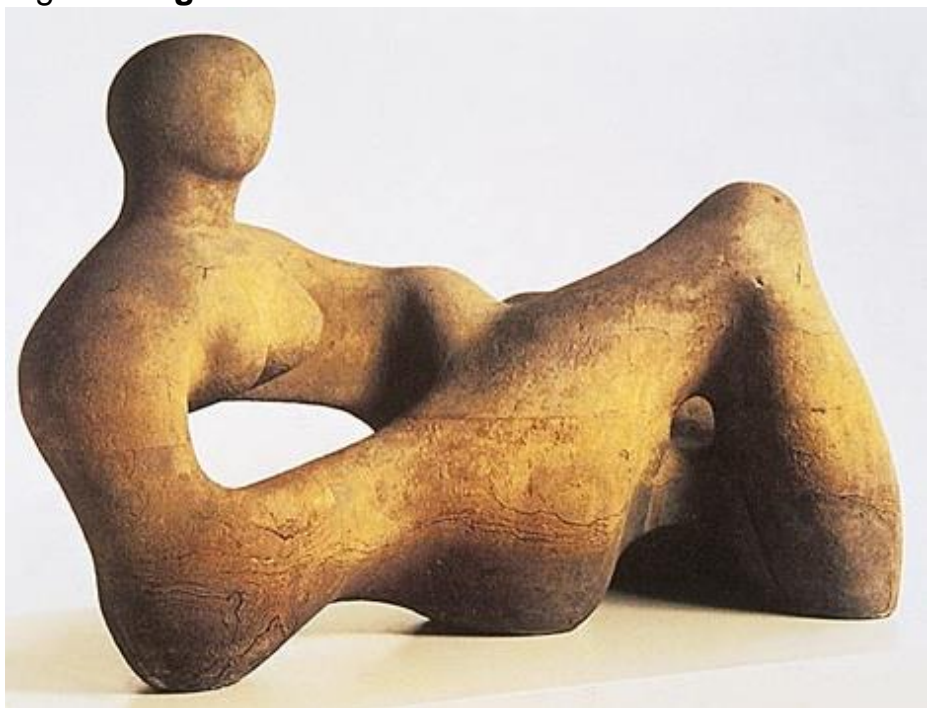

Obra: Henri Moore, 1938.

Fig. 107- Estudos de corpo para obra Duo Corpos.
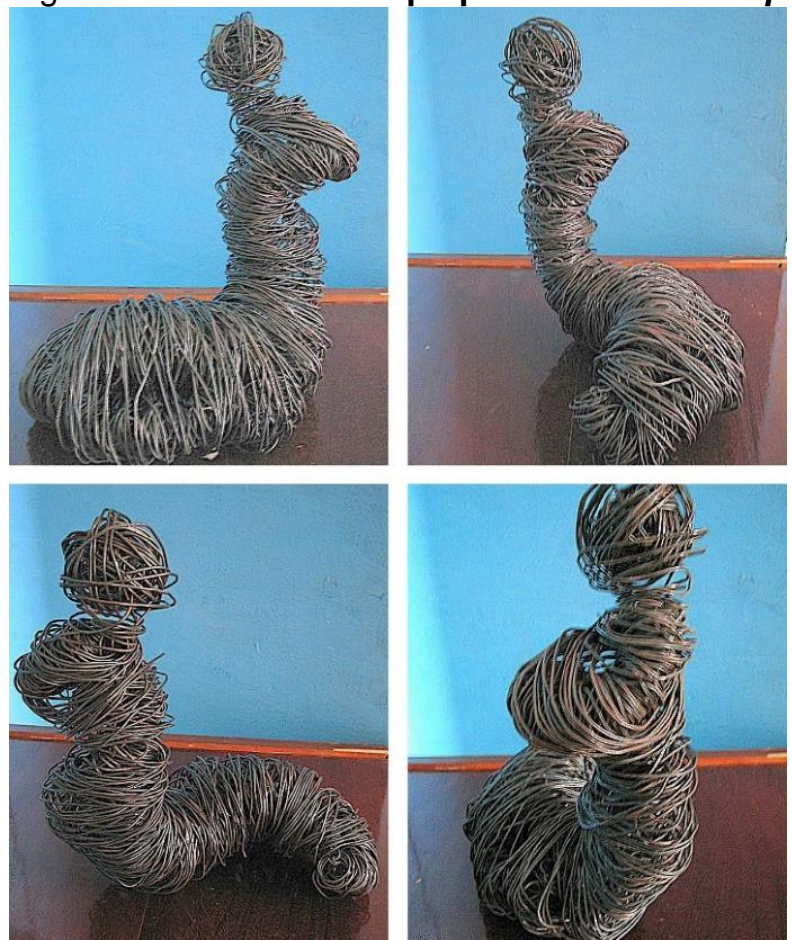

Obra e Foto: Tatiana Rodrigues, 2006.

${ }^{80}$ Disponível em: <http://www.infopedia.pt/\$figura-reclinada-de-henry-moore> Acesso em: 26 mar.2014. 20:32:24. 
As discussões teóricas e questionamentos envolvendo o tema corpo agregaram elementos à composição como, por exemplo, o símbolo do infinito. Seguindo esse contexto, o projeto final abarcou o gênero feminino e o masculino em uma mesma massa corpórea. O material escolhido para a escultura foi ferro, e as cores, azul e vermelho, reforçam a oposição entre os gêneros.

Fig.108- Duo Corpos.
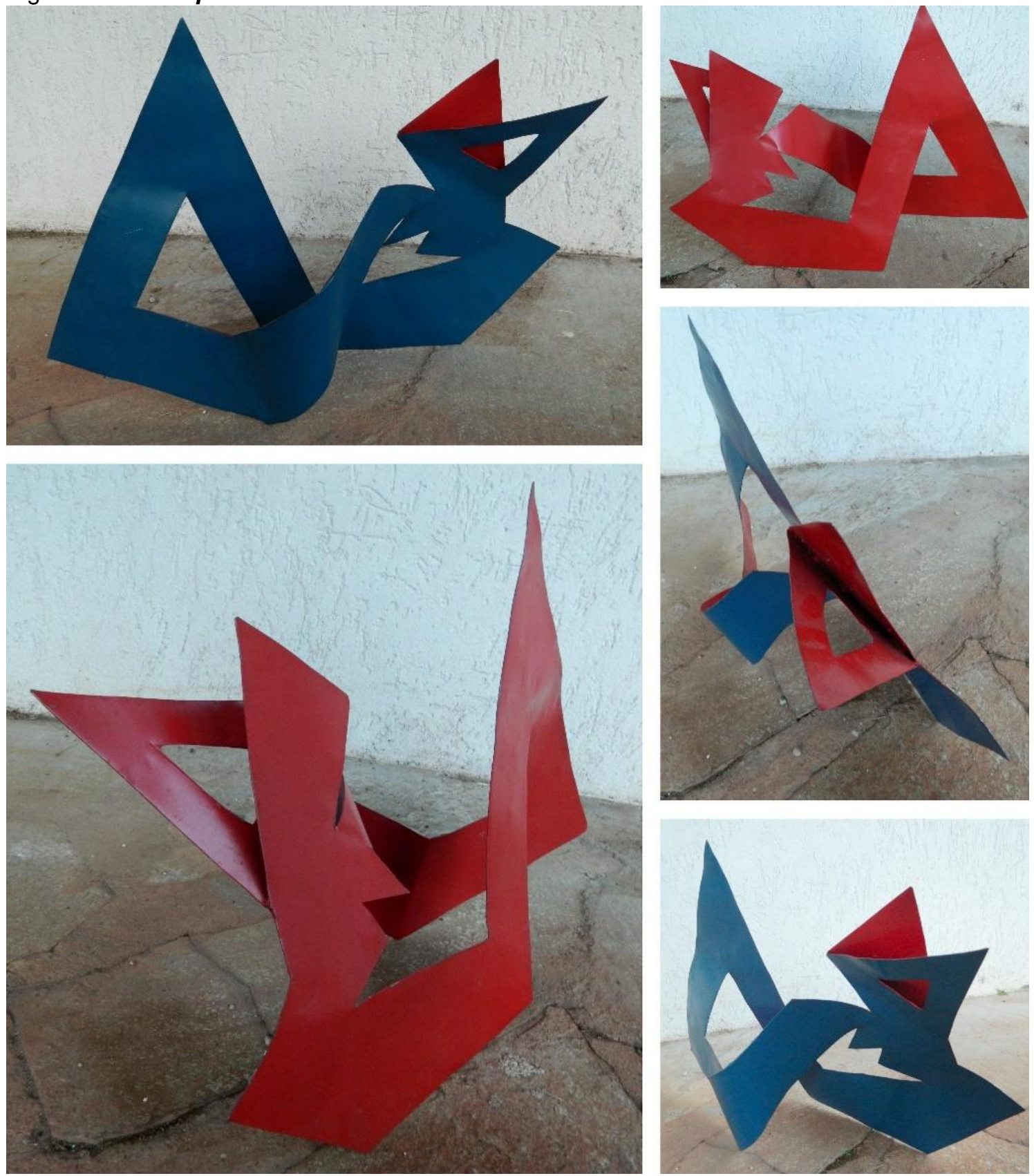

Obra e Foto: Tatiana Rodrigues, 2006.

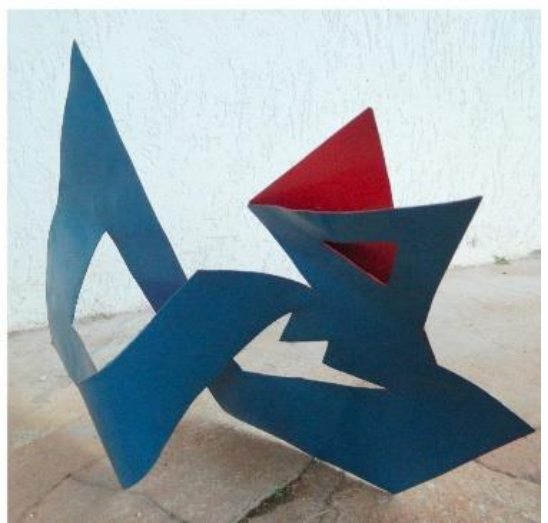


O trabalho intitulado Metamorfoses (2008) é uma maquete que objetivou o estudo dos elementos visuais e conceituais desenvolvidos para o planejamento de uma instalação artística. A abordagem do trabalho consistia em reunir elementos visuais que abrigassem características capazes de (des)construir e/ou construir e/ou ampliar conceitos, tais como: fecundação, metamorfose, criação e vida.

Fig.109- Metamorfoses.
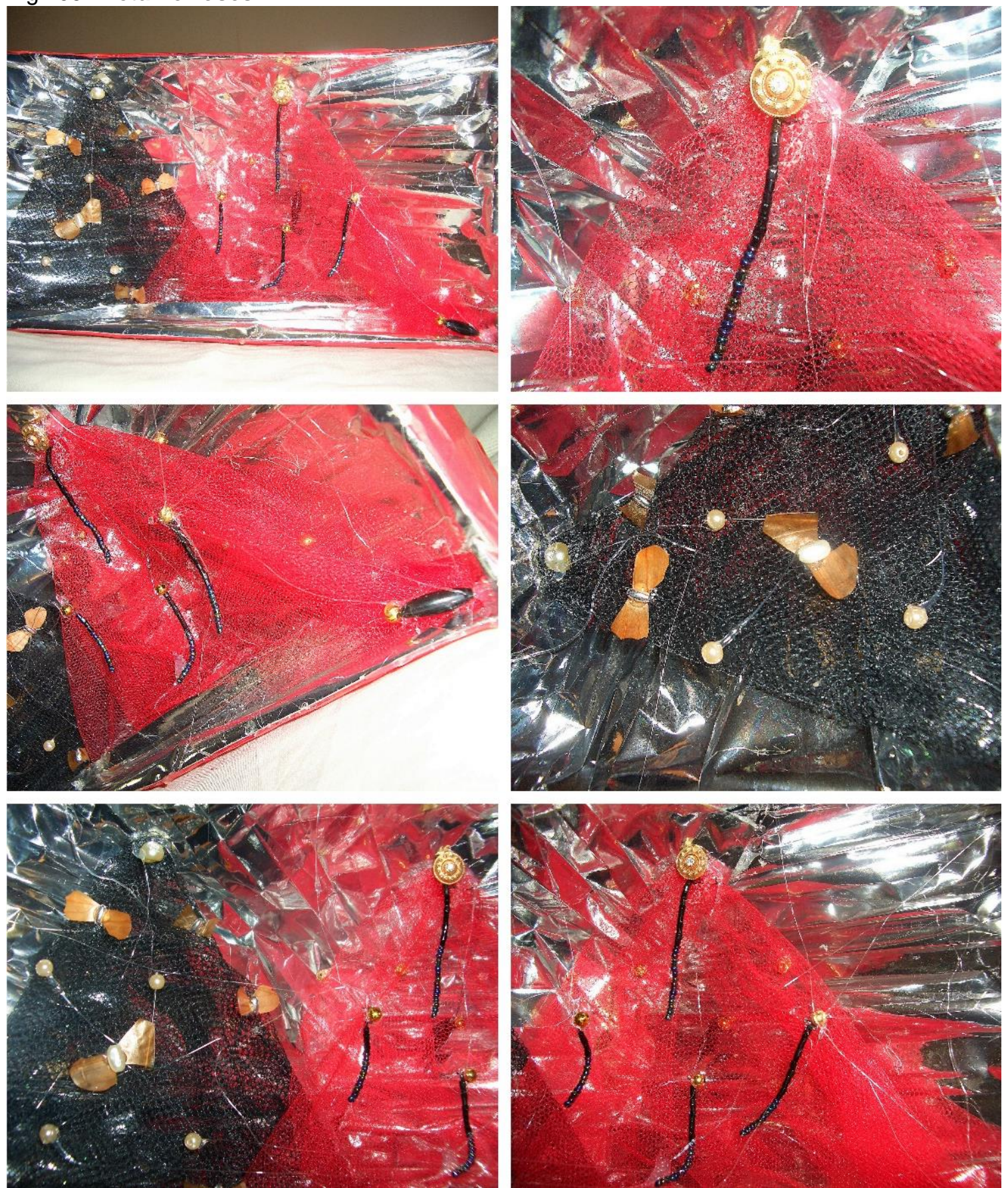

Obra e Foto: Tatiana Rodrigues, 2008. 


\section{Trajetória no âmbito da Arte e Tecnologia}

As pesquisas envolvendo Arte e Tecnologia surgiram a partir do contato teórico-prático com disciplinas que me apresentaram recursos e ferramentas tecnológicas para a criação e manipulação de imagens no contexto artístico. Dentre as inúmeras possibilidades disponíveis, destaco a criação de desenhos, criações vetoriais, pinturas, construção e/ou interferência em imagens e fotografias, por meio de recursos computacionais. Em meio à complexidade de abordagem do tema e os inúmeros recursos disponíveis, os principais softwares podem ser citados: Fractal Paint, Adobe Photoshop, Photo Studio e CorelDraw.

A monografia (2000) desenvolvida no âmbito das artes plásticas pode ser citada como um material que pode ampliar as possibilidades de pesquisa envolvendo a linha de Arte e Tecnologia. Intitulada "Waldemar Cordeiro: O precursor", esta produção intelectual aborda um tema de grande importância para o panorama artístico-tecnológico brasileiro: o pioneirismo do uso de computadores na produção artística contemporânea.

Fig.110-
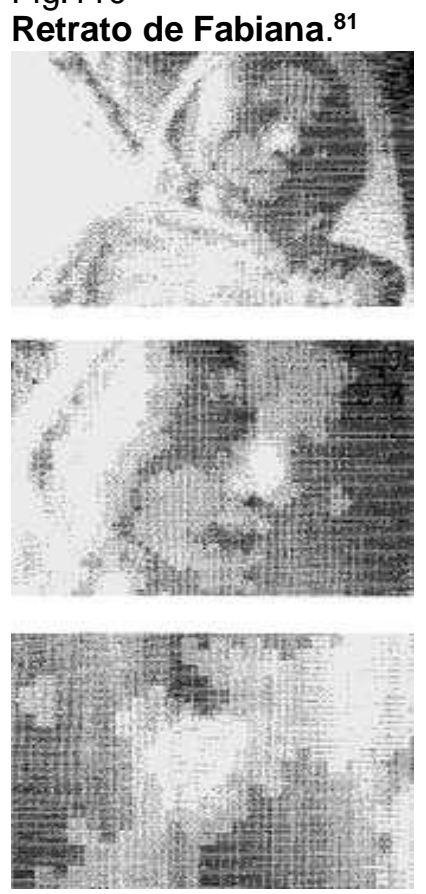

Waldemar Cordeiro, 1970.

Fig.111- A mulher que não é B.B. ${ }^{82}$

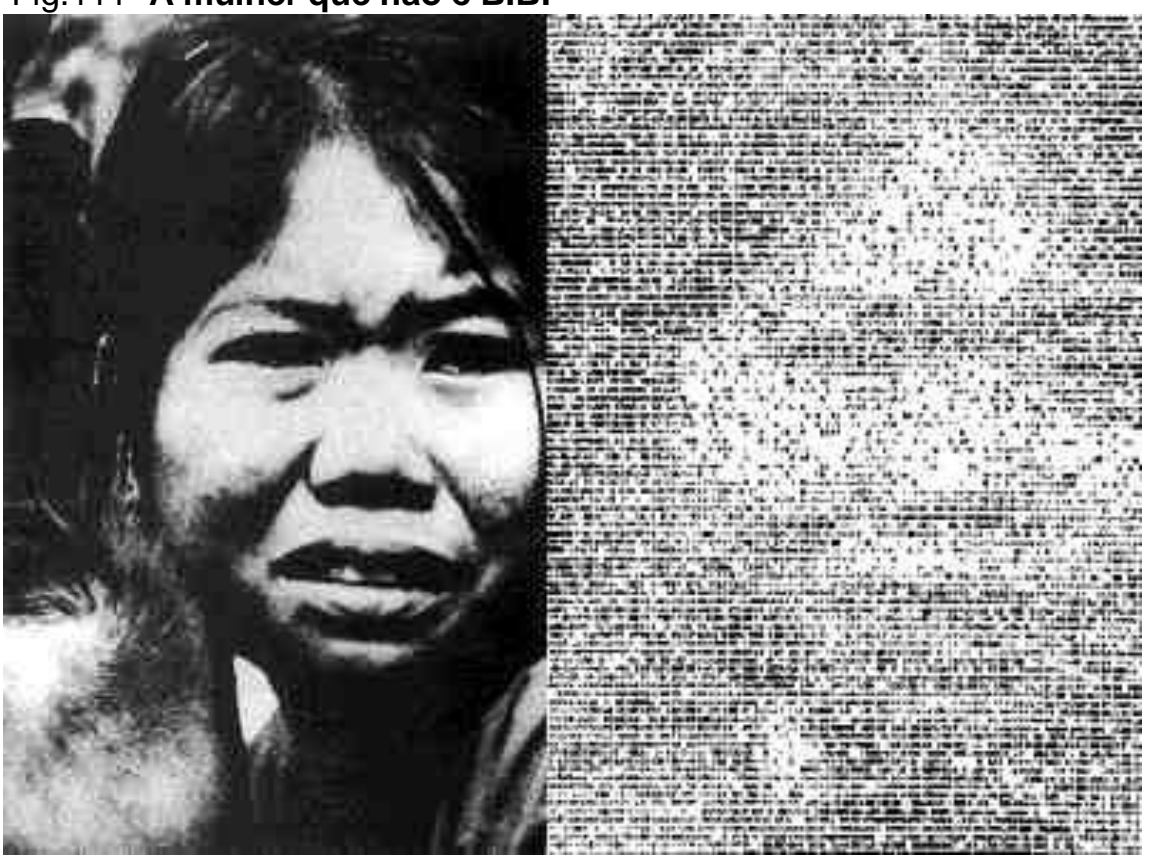

Obra: Waldemar Cordeiro,1971.

81 Disponível em: <http://dada.compart-bremen.de/item/artwork/1278>

Acesso em: 26 mar. 2014. 21:15:48.

82 Disponível em : <http://www.fabiofon.com/webartenobrasil/texto_interartistas2.html> Acesso em: 26 mar. 2014. 21:18:20. 
O interesse pelo tema fotografia surgiu a partir de estudos e experimentações fotográficas desenvolvidas durante as disciplinas e projetos, principalmente, no campo das artes cênicas (2005). Ainda nesse contexto, pode-se afirmar que o estudo das técnicas de iluminação ampliaram as possibilidades e potencialidades investigativas no ambiente artístico-fotográfico. Dessa maneira, a abordagem do tema fotografia enquanto ferramenta artística tornou-se um dos objetos de estudo nesta dissertação.

Fig. 112- Experimentações com fotografia e lluminação.

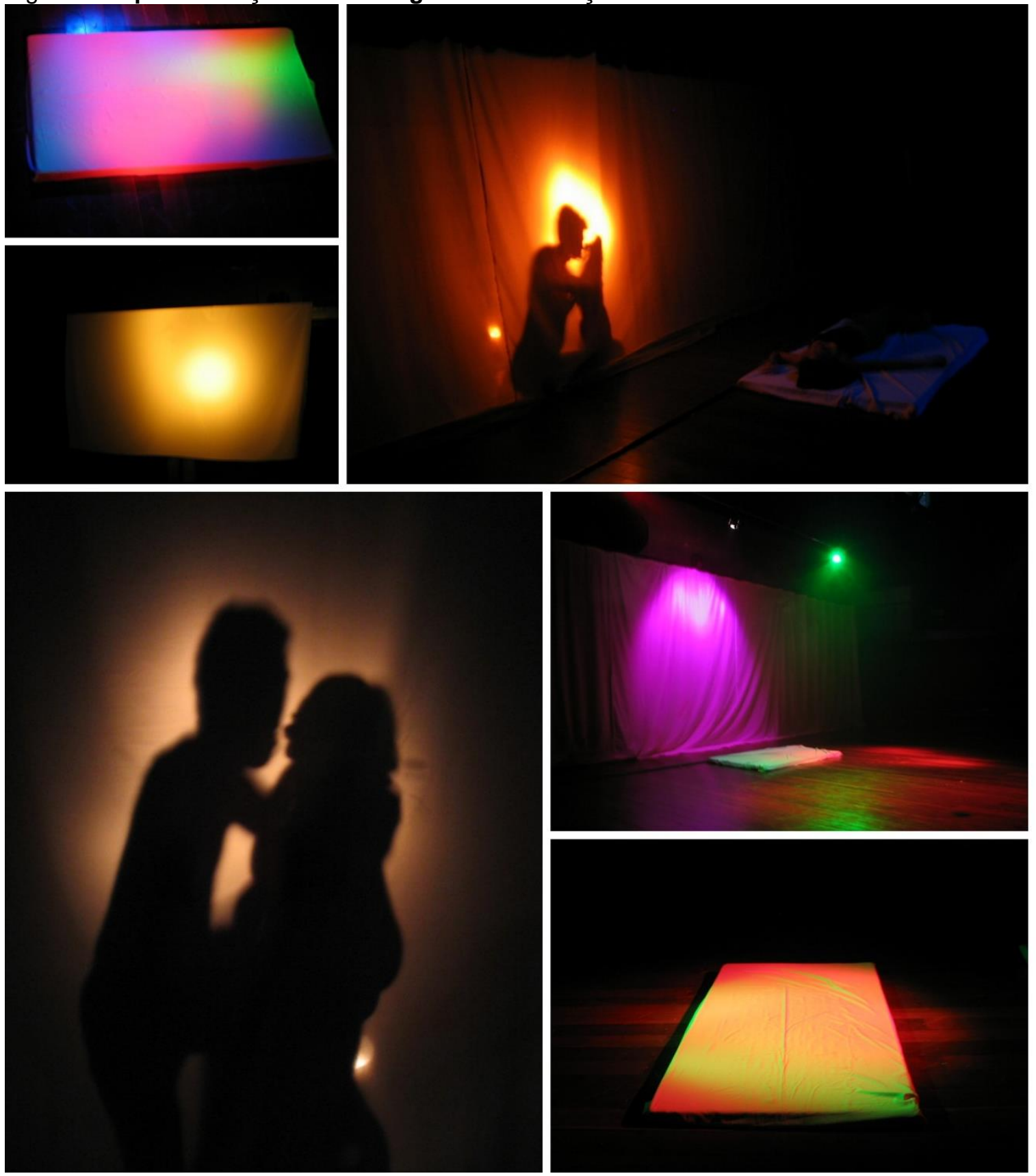

Foto: Tatiana Rodrigues, 2005. 


\section{Percurso do tema marca de nascença: hemangioma}

No ano de 2007, uma série de inflamações e necroses acometeram os hemangiomas em minha perna esquerda. A partir desse contexto, mutações de ordem patológica e estética atuantes nas referidas marcas e, inicialmente, pesquisadas na área médica, tornaram-se alvo de investigações e registros que foram desdobrandose rumo ao âmbito artístico e consolidando-se.

Mais especificamente, no meio do ano de 2007 até 2008, período em que eu vivenciava situação de "estranhamento" em meu corpo, realizei um intercâmbio cultural no Canadá. O hemangioma foi exposto a uma série de situações perturbadoras: descamamento da pele, feridas, dores e queimações, as quais foram sendo registradas por mim. Assim, tornei-me cobaia de inúmeras investigações médicas e recorrentes intervenções que perpassaram desde o estranhamento até o inusitado. Essas experimentações me conduziram a uma nova série de investigações que, progressivamente, voltaram-se tanto para a busca de embasamento teórico quanto para a abordagem no ambiente artístico.

Em 2009, estudos e registros sobre os hemangiomas resultaram em uma série fotográfica que surgiu a partir da composição fotográfica que propunha a interação entre elementos de diferentes naturezas e a referida marca de nascença. Dentre outras análises, pode-se afirmar que esta série fotográfica possibilitou a descontextualização do hemangioma da abordagem restritamente médica e permitiu que ele dialogasse com o universo composicional artístico, bem como, com os seus mais variados objetos e elementos, tais como: cores, texturas, formas, materiais orgânicos, água, dentre outros. 
Fig.113- Série fotográfica 1: Hemangiomas.

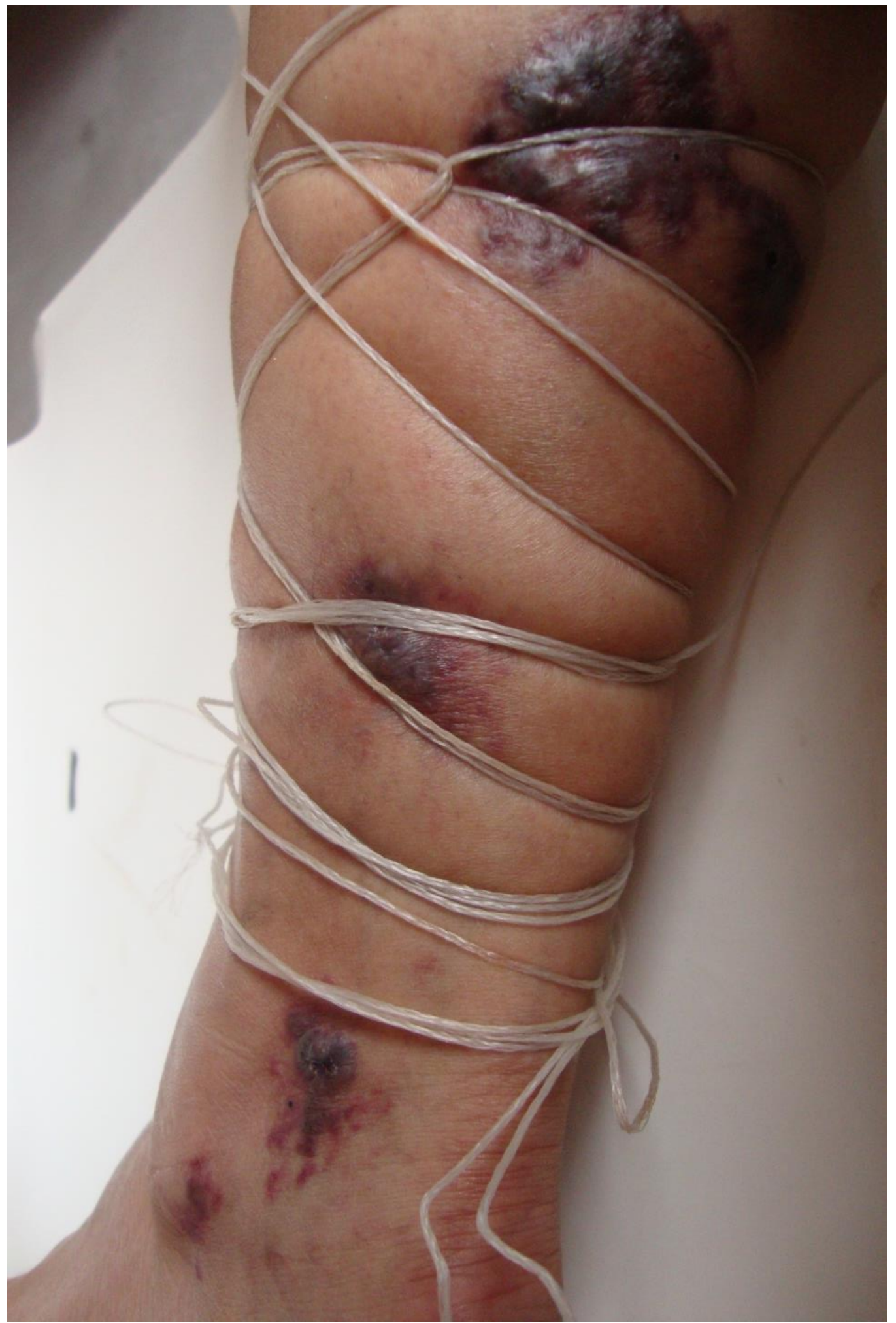

Obra e Foto: Tatiana Rodrigues, 2009. 
Fig.114- Série fotográfica 1: Hemangiomas.

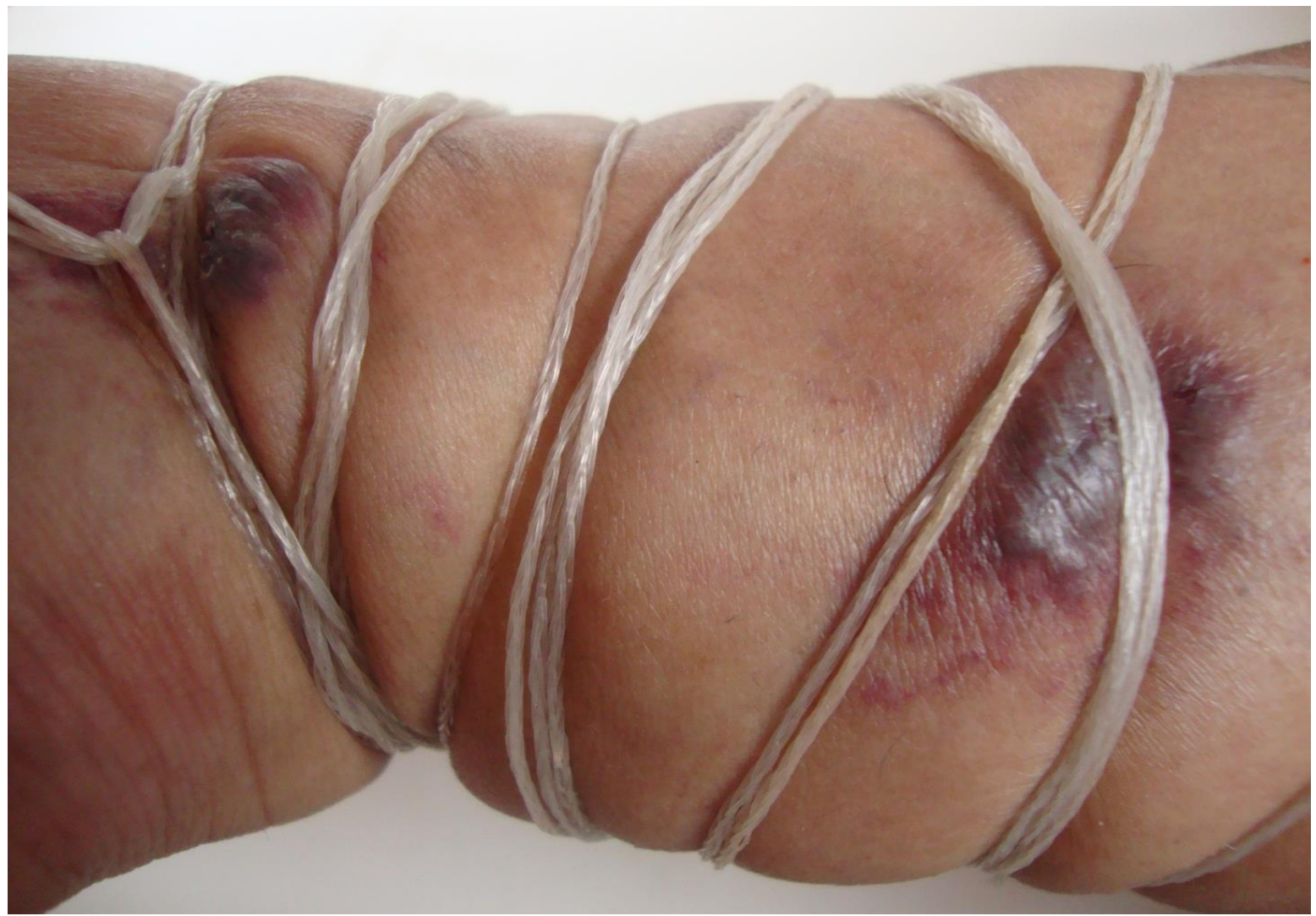

Obra e Foto: Tatiana Rodrigues, 2009.

Fig.115- Série fotográfica 1: Hemangiomas.

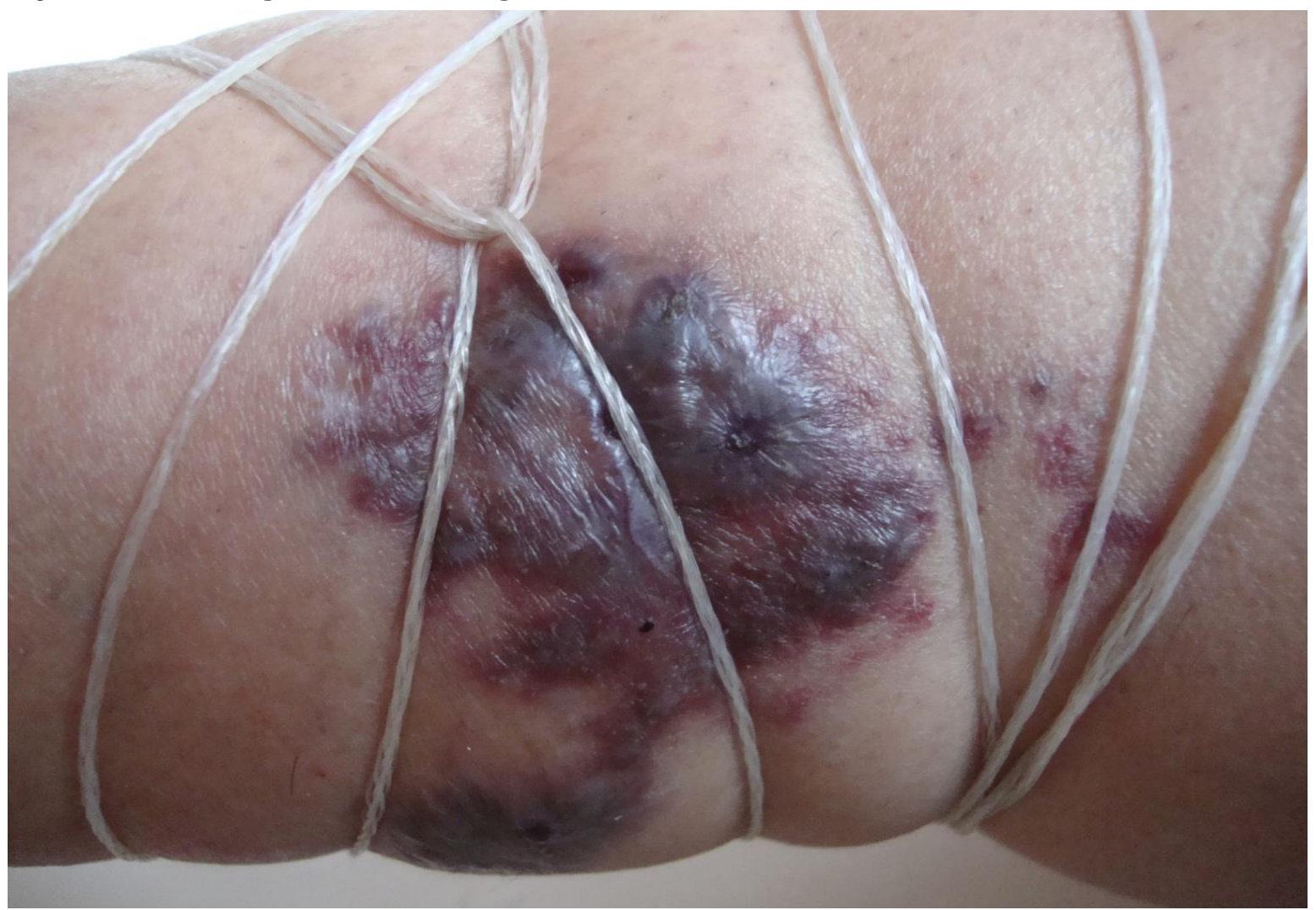

Obra e Foto: Tatiana Rodrigues, 2009. 
Fig.116- Série fotográfica 2: Hemangiomas.
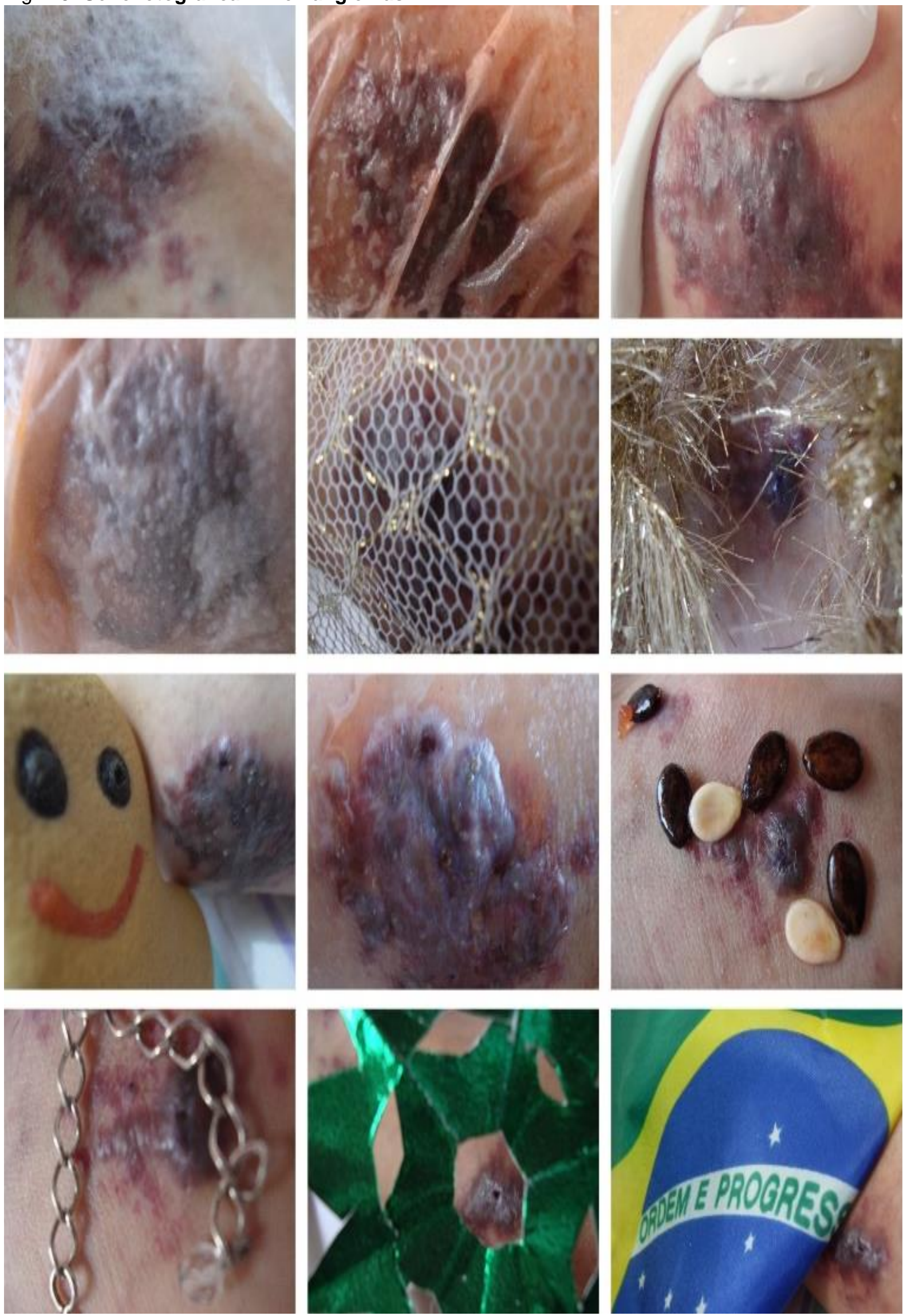

Obra e Foto: Tatiana Rodrigues, 2009. 
Fig.117- Série fotográfica 3: Hemangiomas.
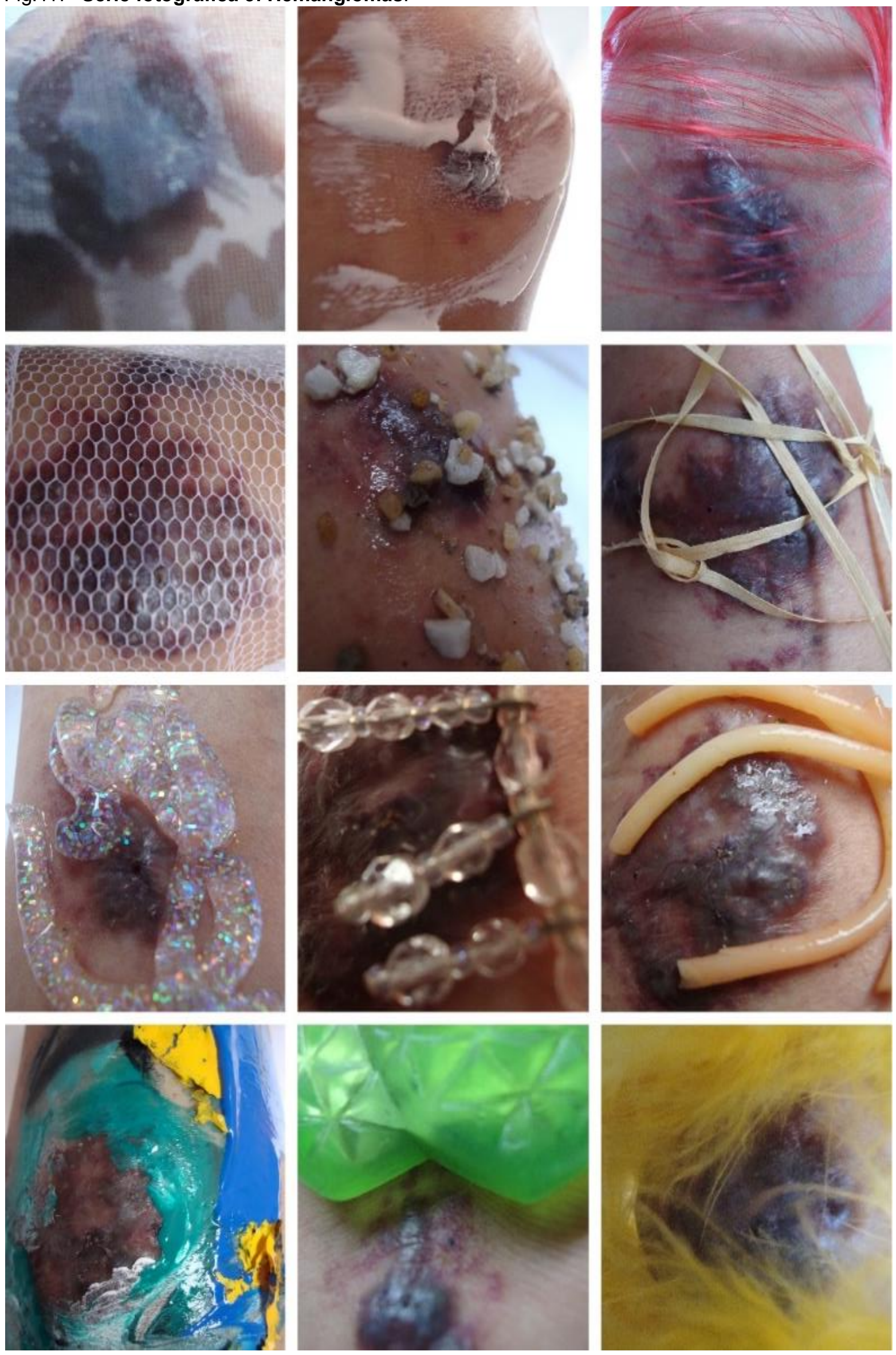

Obra e Foto: Tatiana Rodrigues, 2009. 